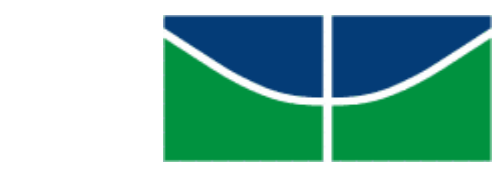

UNIVERSIDADE DE BRASÍLIA

INSTITUTO DE PSICOLOGIA

Programa de Pós-Graduação em Processos de Desenvolvimento Humano e Saúde

DINÂMICAS DE SIGNIFICAÇÃO E TRAJETÓRIAS DE DESENVOLVIMENTO:

EXPERIÊNCIAS DE ESTUDANTES COM DEFICIÊNCIA AUTODECLARADA NA

UNIVERSIDADE

ANA CLAUDIA RODRIGUES FERNANDES

Brasília - DF

2015 


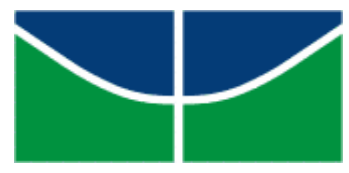

Universidade de Brasília

Instituto de Psicologia

Departamento de Psicologia Escolar e do Desenvolvimento

Programa de Pós-Graduação em Processos de Desenvolvimento Humano e Saúde

Área de concentração: Desenvolvimento Humano e Educação

Linha de pesquisa: Processos de Desenvolvimento e Cultura

\title{
DINÂMICAS DE SIGNIFICAÇÃO E TRAJETÓRIAS DE DESENVOLVIMENTO: EXPERIÊNCIAS DE ESTUDANTES COM DEFICIÊNCIA AUTODECLARADA NA UNIVERSIDADE
}

\author{
ANA CLAUDIA RODRIGUES FERNANDES \\ Tese apresentada ao Instituto de Psicologia da \\ Universidade de Brasília, como parte dos requisitos para \\ a obtenção do título de Doutora em Processos de \\ Desenvolvimento Humano e Saúde, área de concentração \\ Desenvolvimento Humano e Educação.
}

ORIENTADORA: Prof. ${ }^{\text {a }}$ Dr. ${ }^{\text {a }}$ Maria Cláudia Santos Lopes de Oliveira

Brasília - DF, dezembro de 2015. 
Ficha catalográfica elaborada pela Biblioteca Central da Universidade de Brasília.

Acervo

\begin{tabular}{|c|c|}
\hline RR696d & $\begin{array}{l}\text { Rodrigues Fernandes, Ana Claudia } \\
\text { DINÂMICAS DE SIGNIFICAÇÃO E TRAJETÓRIAS DE } \\
\text { DESENVOLVIMENTO: EXPERIENCIAS DE ESTUDANTES COM } \\
\text { DEFICIÊNCIA AUTODECLARADA NA UNIVERSIDADE / Ana } \\
\text { Claudia Rodrigues Fernandes; orientador Maria } \\
\text { Cláudia Santos Lopes de Oliveira. -- Brasilia, } \\
\text { 2015. } 238 \text { p. } \\
\text { Tese (Doutorado - Doutorado em Processos de } \\
\text { Desenvolvimento Humano e Saúde) -- Universidade de } \\
\text { Brasília, } 2015 . \\
\text { 1. Psicologia do Desenvolvimento. 2. Inclusão. } \\
\text { 3. Ensino Superior. 4. Trajetórias de } \\
\text { desenvolvimento. 5. Dinâmicas de significação. I. } \\
\text { Santos Lopes de Oliveira, Maria Cláudia, orient. } \\
\text { II.Título }\end{array}$ \\
\hline
\end{tabular}




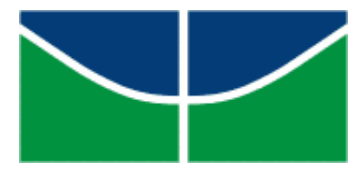

Universidade de Brasília

Instituto de Psicologia

Departamento de Psicologia Escolar e do Desenvolvimento

Programa de Pós-Graduação em Processos de Desenvolvimento Humano e Saúde Área de concentração: Desenvolvimento Humano e Educação

Linha de pesquisa: Processos de Desenvolvimento e Cultura

A Tese de Doutorado "DINÂMICAS DE SIGNIFICAÇÃO E TRAJETÓRIAS DE DESENVOLVIMENTO: EXPERIÊNCIAS DE ESTUDANTES COM DEFICIÊNCIA AUTODECLARADA NA UNIVERSIDADE", de autoria de Ana Claudia Rodrigues Fernandes, foi aprovada pela seguinte banca examinadora:

Prof. ${ }^{a}$ Dr. ${ }^{a}$ Maria Cláudia Santos Lopes de Oliveira - Presidente PGPDS/ PED/ IP/ UnB

Prof. ${ }^{a}$ Dr. ${ }^{a}$ Ângela Maria Cristina Uchoa de Abreu Branco - Membro Titular PGPDS/ PED/ IP/ UnB

Prof. ${ }^{a}$ Dr. ${ }^{a}$ Daniele Nunes Henrique Silva - Membro Titular PGPDS/ PED/ IP/ UnB

Prof. ${ }^{a}$ Dr. ${ }^{a}$ Sônia Maria Rocha Sampaio - Membro Titular Universidade Federal da Bahia - UFBA

Prof. ${ }^{a}$ Dr. ${ }^{a}$ Erenice Natália Soares de Carvalho - Membro Titular Universidade Católica de Brasília

Prof. ${ }^{a}$ Dr. ${ }^{a}$ Sueli de Souza Dias - Membro Suplente

Secretaria de Educação do Distrito Federal - SEEDF

Brasília - DF, dezembro de 2015 
Àqueles por quem vivo:

Meu filho e esposo amados (Pedro Antonio e Ivo Antonio), pelo amor, compreensão, apoio, colo e presença em minha vida. A vida é plena porque vocês existem. São os presentes que Deus guardou para mim!

Minha mãe guerreira (Eltenyr) pelo carinho, dedicação, responsabilidade, humildade $e$ cuidado. Levo comigo todos os ensinamentos $e$ exemplos de vida ofertados por ela. Minha maior amiga!

Meus familiares e amigos pelo incentivo, carinho $e$ compreensão. Entenderam $e$ apoiaram meu investimento acadêmico e os anos de "dedicação exclusiva" e consequente ausência. Um caminho sem família e amigos, nem é caminho!

A Deus, mestre maior de nossas trajetórias! 


\section{AGRADECIMENTOS}

O momento de apresentar meus agradecimentos é oportunidade de revisitar os últimos quatro anos na minha trajetória. Como estudante do Desenvolvimento Humano, consigo perceber as muitas marcas dos eventos de ruptura e transição que desenharam a experiência acadêmica desse tempo.

Foi um tempo de dificuldade, mas também de superação; de esforço e também de sucesso; de dúvidas, mas também descobertas; de solidão e também parceria; enfim, um tempo de luta, mas acima de tudo, repleto de vitória. Significados em ambivalência delineando a vida, construindo uma trajetória da qual me orgulho.

E na certeza de que minha trajetória não foi construída só por mim, mas na interação e parceria com as palavras e pensamentos daqueles e daquelas que partilharam comigo a experiência, num diálogo intenso, quero agradecer pela companhia na caminhada. Agradeço...

À minha orientadora, Maria Cláudia, pela amizade, dedicação, paciência, ensinamentos, cuidado e apuro que mobilizam em nós, seus orientandos, motivação para responder à altura. Seu exemplo de competência, responsabilidade e ética é irretocável.

Aos participantes de pesquisa, que partilharam com interesse suas histórias de vida e superação. Agradeço imensamente a confiança.

Às professoras do Programa, pelos saberes partilhados com dedicação e competência

em diferentes atividades e oportunidades: Ângela Branco, Daniele Nunes, Silviane Barbato, Claisy Marinho-Araújo, Denise Fleith, Diva Maciel, Maristela Rossato, Regina Sucupira, Lúcia Pulino, Gabriela Mieto. 
Aos colegas de estudo do LABMIS, pelas oportunidades de aprendizado partilhadas ao longo desse tempo.

À professora Erenice Natália, pela presença e palavras de ânimo em momentos importantes no percurso: Jornada de Pesquisa, processo de Estágio no Exterior e banca examinadora.

Às professora Alexandra Anache e Daniele Nunes pelas contribuições no exame de qualificação. O apoio e atenção dispensados contribuíram literalmente na qualificação da pesquisa.

Ao professor Leandro Almeida, pela acolhida em Portugal, disponibilidade, colaboração, partilha e torcida. Um exemplo a ser seguido. Profissional espetacular!

Às professoras das universidades portuguesas: Ana Antunes, Alexandra Araújo, Eugênia Fernandes, Lília Aguardenteiro, Sandra Estevão, Maria Alice Ribeiro e Maria Altina Ramos. A acolhida, o apoio e as contribuições muito agregaram ao trabalho e tornaram mais agradável a estada na querida cidade de Braga.

Aos colegas de grupo pela parceria e suporte nesse tempo: Sueli, Dayane, Daniela, Fernanda, Kélita, Alexandre, Davi, Cláudio, e mais recentemente, Nilcea, Izete, Raissa, Tereza, Caroline, Aedra. Com vocês, a carga foi literalmente dividida e se tornou mais leve.

Às queridas Mónica Roncacio, Milena, Albenira, Sandra, Elizeth, Bárbara, Cândida e Vanda Regina pelas parcerias construídas ao longo do caminho.

Aos funcionários do PGPDS pela disponibilidade, especialmente à Cláudia Freire, pela ajuda competente.

À Secretaria de Estado de Educação do Distrito Federal e à Capes pelos apoios disponibilizados.

Muito obrigada a todos! 
Esta pesquisa contou com os seguintes apoios institucionais

Secretaria de Estado de Educação do Distrito Federal

Concessão de Afastamento Remunerado para Estudos

(DODF: 09/04/2013, Processo 080.001093/2013 )

Autorização para Realização de Estágio Doutoral no Exterior

(DODF: 14/08/2014, Processo 080.004819/2014)

Comitê de Ética em Pesquisa do Instituto de Ciências Humanas (UnB)

Aprovação do projeto de pesquisa. Processo 433.354/2013

Coordenação de Aperfeiçoamento de Pessoal de Nível Superior (Capes). Concessão de bolsa de estudos para a realização do Estágio de Doutorado em Portugal.

Processo PDSE: 99999.005172/2014-04

Universidade do Minho - local de realização do Estágio de Doutorado no Exterior, sob supervisão do Prof. Dr. Leandro da Silva Almeida. 
A inclusão acontece quando se aprende com as diferenças e não com as igualdades. 


\section{RESUMO}

Fernandes, A. C. R. (2015). Dinâmicas de significação e trajetórias de desenvolvimento: experiências de estudantes com deficiência autodeclarada na universidade.

A investigação teve por objetivo compreender a dinâmica de significação e as trajetórias de desenvolvimento pessoal de estudantes com deficiência, mediadas pelas experiências institucionais e subjetivas na vida cotidiana em universidades. O estudo se interessou pelos diferentes aspectos de sua experiência como estudante do ensino superior em dois países: Brasil e Portugal. Universidades são, notadamente, contextos meritocráticos, altamente desafiadores, em especial para aqueles estudantes com deficiências, que encaram várias barreiras para entrar, serem adequadamente qualificados e bem sucedidos na obtenção do diploma. A abordagem metodológica foi qualitativa e longitudinal: Quatro instituições de ensino superior em ambos os países, quatro técnicos profissionais e oito estudantes foram investigados, sendo que a investigação consistiu de entrevistas individuais e análise de cartas (escritas um ano depois das entrevistas). Considerando os propósitos do estudo, três eixos de investigação e análise foram construídos que favoreceram a abordagem dos estudantes e profissionais do serviço de inclusão de cada universidade, com o objetivo de chegar a uma compreensão aprofundada do fenômeno da inclusão no ensino superior. O primeiro eixo apresenta as estratégias adotadas como parte do sistema de inclusão pedagógica de cada universidade investigada; o segundo focaliza as experiências vividas pelos estudantes com deficiência; e o último eixo explora, adotando uma perspectiva idiográfica, as trajetórias ao longo do ensino superior de três participantes (dois brasileiros e um português), considerando suas narrativas nas entrevistas e nas cartas. As análises, no que se referem ao primeiro e segundo eixos, são coerentes com a inferência de que os estudantes enfrentam importantes desafios e necessitam ultrapassar obstáculos cotidianos que se referem às barreiras ambientais e simbólicas dentro da educação superior: inadequação ou insuficiência de serviços; estrutura arquitetônica imprópria; preconceito e invisibilidade de suas necessidades acadêmicas pelos professores; baixa prioridade da educação especial em termos dos investimentos e política institucional, deixando suas necessidades específicas não atendidas. No que se refere ao terceiro nível, as análises conduziram à proposição de um constructo para interpretar a dinamicidade do desenvolvimento pessoal humano: esferas da subjetividade. No tempo irreversível, o desenvolvimento é concebido de acordo com uma organização semióticotemporal do self, considerando o contexto e as experiências relacionais específicas vividas pelo sujeito. A investigação busca contribuir para a interpretação de processos de desenvolvimento em vários contextos, em especial, os que envolvam aquelas trajetórias mediadas por eventos disruptivos ou caminhos não-normativos, como acontece quando deficiências estão envolvidas.

PALAVRAS-CHAVE: Inclusão, ensino superior, processos de significação, trajetórias de desenvolvimento. 


\begin{abstract}
Fernandes, A. C. R. (2015). Dynamics of signification and developmental trajectories: considering the experience of students with disabilities in universities.

The investigation aimed at understanding the dynamics of signification and trajectories of personal development of students with disabilities, mediated by institutional and subjective experience in the daily life of the universities. The study was concerned by different aspects of their experience as higher education students into two countries: Brasil and Portugal. Universities are, notably, meritocratic contexts, highly challenging, in special for those students with disabilities, who face various barriers to stay in, to be adequately qualified and to succed in obtaining the degree. The methodological approach was qualitative and longitudinal (two points). Four higher education institutions in both countries, four technical professional and eight students were investigated, consisting of individual interviews and analysis of letters (written one year after the interviews). Considering the purposes of the study, three axels of investigation and analysis were constructed that favored the approach of the students and professionals of the inclusion office of each university, aiming at a deep comprehension of the phenomena of inclusion in higher education. The first axel presents the strategies adopted as part of the inclusion pedagogic system of each university investigated; the second focuses on the living experiences of the higher education students with disabilities; the last axel explores, adopting an idiographic stance, the trajectories along higher education of three participants (two Brazilians and a Portuguese), considering their narratives in the interviews and letters. Analysis, regard the first and second axels, are coherent with the inference that students face important barriers and need to surpass daily obstacles concerning environmental and symbolic restraints within higher education: Inadequacy or insufficiency of services; improper architectonic structure; prejudice and invisibility of their academic needs by professors; low priority of special education in terms of investments and institutional politics, leaving their specific needs unattended. Concerning the third level, analysis conducted to the proposition of one construct to interpret the dinamicity of human personal development: spheres of subjectivity. In the irreversible time, development is designed according to the temporal semiotic organization of the self, considering the context and the specific relational lived experiences of the subject. The present investigation may contribute to the interpretation of developmental processes in several contexts, in special, concerning those trajectories mediated by disruptive events or non-normative paths, such as when disabilities are involved.
\end{abstract}

Key-words: Inclusion, higher education, process of signification, trajectories of development. 


\section{SUMÁRIO}

AGRADECIMENTOS Vi

RESUMO $\quad \mathrm{x}$

ABSTRACT $\quad x i$

SUMÁRIO xii

LISTA DE FIGURAS, GRÁFICOS E QUADROS xiv

APRESENTAÇÃO

INTRODUÇÃO 3

FUNDAMENTAÇÃO TEÓRICA

1. DEFICIÊNCIA E INCLUSÃO EDUCACIONAL: ASPECTOS 7

HISTÓRICOS, CONCEITUAIS E LEGAIS

1.1 Construção histórico-social da deficiência e das práticas de educação $\begin{array}{ll}\text { especial } & 7\end{array}$

1.2 Transformações das abordagens e práticas para a deficiência no Brasil $\quad 10$

1.3 Desdobramentos dos processos históricos sobre as significações e a $\begin{array}{ll}\text { normatização da deficiência } & 17\end{array}$

1.3.1 Diretrizes nacionais e internacionais: do meio médico às práticas $\begin{array}{ll}\text { Educacionais } & 17\end{array}$

1.3.2 Inclusão: um conceito em contínuo delineamento 24

1.4 Aspectos normativos da educação inclusiva 28

2. EDUCAÇÃO SUPERIOR: ASPECTOS HISTÓRICOS E PANORAMA

ATUAL $\quad 36$

2.1 Educação superior brasileira: Aspectos históricos 36

2.2 Educação superior brasileira: Panorama atual $\quad 42$

2.3 A inclusão no ensino superior: Desafios e perspectivas 47

2.4 Educação inclusiva e ensino superior em Portugal 51

3. PSICOLOGIA DO DESENVOLVIMENTO HUMANO: PERSPECTIVAS E INTERPRETAÇÕES

3.1 Perspectiva semiótico-cultural e dialógica 55

3.2 A universidade como contex to de desenvolvimento humano 64

3.3 O ensino superior e o desenvolvimento de estudantes com deficiência $\quad 67$

3.4 As ambivalências e as trajetórias de desenvolvimento adulto 69

3.5 Esferas da subjetividade na compreensão da trajetória de $\begin{array}{ll}\text { desenvolvimento } & 71\end{array}$

$\begin{array}{ll}\text { OBJETIVOS } & 75\end{array}$

4. METODOLOGIA

4.1 Fundamento teórico-metodológico 76

4.2 Desenho e instrumentos 80

$\begin{array}{ll}\text { 4.2.1 Entrevistas } & 82\end{array}$

$\begin{array}{ll}\text { 4.2.2 Cartas } & 83\end{array}$

4.3 Contextualização $\quad 84$

4.3.1 Critérios de seleção dos participantes $\quad 85$

$\begin{array}{ll}\text { 4.3.2 Participantes } & 86\end{array}$

$\begin{array}{ll}4.4 \text { Procedimentos éticos } & 88\end{array}$

4.5 Instrumentos e materiais $\quad 89$

$\begin{array}{ll}4.6 \text { Procedimentos de análise } & 90\end{array}$ 
RESULTADOS

5. ATUAÇÃO E CONTRIBUTOS DOS SISTEMAS DE APOIO À INCLUSÃO NO ENSINO SUPERIOR

5.1 Os sistemas e sua atuação: Múltiplos olhares e ações

6. A UNIVERSIDADE NA VOZ DOS ESTUDANTES: DESAFIOS À INCLUSÃO

6.1 A vivência com os professores: Impasses, preconceitos e desafios

108

6.2 A relação com os colegas de turma: Experiência positiva com a alteridade

6.3 O papel dos serviços institucionalizados de apoio

6.4 A acessibilidade nos espaços da universidade

6.5 Qualificação das práticas inclusivas na universidade: A voz dos estudantes

\section{A PERSPECTIVA IDIOGRÁFICA: NARRATIVAS DAS}

TRAJETÓRIAS ESTUDANTIS

7.1 João: Os desafios de um guerreiro 129

$\begin{array}{ll}\text { 7.1.1 A relevância do caso } & 132\end{array}$

$\begin{array}{ll}\text { 7.1.2 A trajetória de João } & 132\end{array}$

7.1.3 A tensão entre os significados eu-estudante e eu-trabalhador 133

7.1.4 A tensão entre os significados eu-eficiente e eu-deficiente 135

7.2 Maria: A inconveniente busca pela autonomia em resposta à $\begin{array}{ll}\text { deficiência visual progressiva } & 145\end{array}$

$\begin{array}{ll}\text { 7.2.1 A relevância do caso } & 146\end{array}$

$\begin{array}{ll}\text { 7.2.2 A trajetória de Maria } & 147\end{array}$

7.2.3 A tensão entre os significados eu-eficiente e eu-inconveniente $\quad 148$

$\begin{array}{ll}\text { 7.2.4 A tensão entre os significados eu-eficiente e eu-deficiente } & 150\end{array}$

$\begin{array}{ll}7.3 \text { Alice: De (má)aluna à lutadora por direitos } & 157\end{array}$

$\begin{array}{ll}\text { 7.3.1 A relevância do caso } & 159\end{array}$

$\begin{array}{ll}\text { 7.3.2 A trajetória de Alice } & 160\end{array}$

7.3.3 A tensão entre os significados eu-má aluna e eu-informada $\quad 160$

7.3.4 A tensão entre os significados eu-deficiente e eu-diferente 163

7.4 Aproximações entre os casos: Compreensões sobre a deficiência 171

8. DISCUSSÃO DOS RESULTADOS 172

8.1 Trajetórias de estudantes com deficiência na universidade: Proposições

de indicadores para a ação

8.1.1 As vozes dos estudantes: Indicadores para práticas mais inclusivas na Universidade

8.1.1.1 A formação docente para a inclusão 176

$\begin{array}{ll}\text { 8.1.1.2 A ação dos sistemas de apoio } & 178\end{array}$

8.1.1.3 A criação de políticas de inclusão 180

8.1.1.4 A importância dos pares nas práticas estudantis 181

8.2 Trajetórias de estudantes com deficiência na universidade: $\mathrm{O}$ fenômeno $\begin{array}{lr}\text { do desenvolvimento } & 183\end{array}$

CONSIDERAÇÕES FINAIS $\quad 188$

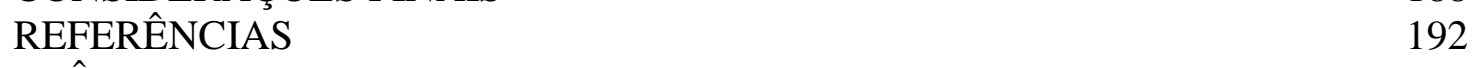

$\begin{array}{ll}\text { APENNDICES } & 210\end{array}$

$\begin{array}{ll}\text { ANEXOS } & 216\end{array}$ 


\section{LISTA DE FIGURAS}

$\begin{array}{ll}\text { Figura 1- Desenho metodológico da pesquisa } & 81\end{array}$

Figura 2- Representação das esferas da trajetória nos processos de significação 185

\section{LISTA DE GRÁFICOS}

Gráfico 1 - Distribuição da população por nível de escolarização

\section{LISTA DE QUADROS}

Quadro 1 - Pesquisas acadêmicas sobre deficiência no ensino superior (2000-2013)

Quadro 2 - Síntese da legislação e dispositivos legais pertinente à educação especial e inclusiva escolar 


\section{APRESENTAÇÃO}

Diferentes e confluentes motivações culminam na tese aqui apresentada. De início, a atuação como professora da educação básica na rede pública de ensino há vinte anos. Durante esse período, trabalhei na inclusão escolar de estudantes dos anos iniciais como regente, professora de sala de recursos e, ainda, diretora de uma escola de educação básica inclusiva. A experiência alimentou o interesse por melhor compreender a temática. Também foi motivadora a busca de orientação para minha práxis profissional e a consequente qualificação do atendimento e desenvolvimento dos estudantes, que, nas minhas experiências e vivências na escola, sempre representaram, no mínimo, um desafio. Motivações pessoais e profissionais se misturaram na ânsia por uma escola e educação capazes de perceber e valorizar as potencialidades de todos, indistintamente.

Ao refletir sobre a motivação científica e acadêmica para este processo de definição de seu objeto, creio que o tema revelou-se um importante desafio. A pesquisa aborda a educação inclusiva no contexto do ensino superior, etapa de escolarização marcada por desafios e características específicas e da qual muitos indivíduos ainda estão excluídos. É uma situação com diversas causas geralmente, problemas de ordem econômica, educacional e/ou social, que, portanto, não se relacionam diretamente à deficiência. Nessa perspectiva, levantamos reflexões que discutem a inclusão de pessoas com deficiência no ensino superior. São abordados: a organização dos sistemas institucionais de apoio à inclusão na universidade; os desafios e impasses vivenciados pelos estudantes universitários com deficiência; e as narrativas das trajetórias de desenvolvimento pessoais e acadêmicas de três universitários com deficiência. 
O estudo suscitou diversas discussões: (a) a novidade da inclusão no ensino superior, objeto pouco explorado nas pesquisas em educação; (b) a ênfase da psicologia do desenvolvimento nos anos iniciais do desenvolvimento, que a tem levado a aprofundar pouco na juventude e na vida adulta; (c) o ensino superior como contexto de desenvolvimento social e humano; (d) a necessidade de aprimoramento de metodologias para assegurar a educação inclusiva em contextos ainda mais complexos que a escola de educação básica, a exemplo do ensino superior; (f) os valores e preconceitos que medeiam as interações humanas nesse contexto.

Este estudo contribui para o debate sobre as práticas inclusivas na universidade. $\mathrm{O}$ valor heurístico da pesquisa se relaciona à interpretação dos processos de desenvolvimento que decorrem de eventos ou experiências peculiares, como o fenômeno da deficiência. 


\section{INTRODUÇÃO}

Nas últimas décadas, a inclusão de jovens com deficiência tem se feito presente nos espaços acadêmicos, políticos e sociais, evidenciando os resultados das políticas de inclusão. A despeito da relevância das práticas inclusivas, sua complexidade requer estudos capazes de ampliar a compreensão dos processos de desenvolvimento e das demandas dos jovens como parte de distintos contextos de inclusão social, entre eles a escola. Nesse espaço, a inclusão tem representado um importante desafio, que se manifesta de modo peculiar nos diferentes níveis e modalidades de ensino, em instituições públicas ou privadas. O avanço no debate sobre a temática fomenta a construção de práticas mais qualificadas e justas, ao problematizar o papel da sociedade e aqui, especificamente, da Instituição de Ensino Superior (IES).

É necessário refletir sobre os processos inclusivos no espaço da IES. A crescente procura de jovens com deficiência pelo ensino superior não tem sido acompanhada do aprofundamento do debate sobre o tema. Dados da Secretaria Nacional da Pessoa com Deficiência (SNPD, 2013) apontam a evolução das matrículas de estudantes com deficiência no ensino superior, tomando como ponto de partida o ano de 2003 em que foram feitas 5.078 matrículas, que ao longo dos anos foram se ampliando, e chegaram em 2011, a 23.250 matrículas, distribuídas em instituições públicas e privadas.

Embora falemos de demanda ampliada, destacamos que a expansão é ainda modesta, porque o acesso ao ensino superior está restrito a uma parte reduzida da população. Ainda não podemos afirmar que o acesso ao ensino superior se reflete em condições adequadas de permanência e aproveitamento da experiência acadêmica. A busca por práticas mais efetivas 
para a inclusão pode proporcionar aos estudantes o exercício de direitos e cidadania, motor para a inclusão em esferas cada vez amplas da sociedade.

Na mesma proporção que cresce o número de jovens com deficiência que concluem o ensino médio e estão em condições de ingressar no ensino superior, aumenta a demanda de fortalecimento da educação inclusiva no ensino superior. Nesse grupo, hoje, um número modesto acessa o ensino superior e um número ainda menor conclui com êxito esse nível de ensino. Segundo dados da Secretaria Nacional de Promoção dos Direitos da Pessoa com Deficiência (SNPD, 2013), 10,4\% das pessoas sem deficiência concluem o ensino superior, ao passo que o percentual das pessoas com deficiência cai para $6,7 \%^{1}$. Poucas são as informações censitárias que se detêm sobre tal segmento dos universitários e reduzidos são os estudos que investigam suas trajetórias no ensino superior.

Com este estudo, pretendemos interligar a trajetória subjetiva e a experiência acadêmica do indivíduo com deficiência no ensino superior. Para isso, consideramos os processos semióticos constituintes dos sistemas de significados dos estudantes, tomando como contexto a experiência educacional na universidade. Alinhada com a perspectiva da psicologia do desenvolvimento, em sua matriz dialógica e semiótico-cultural, a pesquisa pretende colaborar para a compreensão dos processos de significação que constituem as trajetórias de desenvolvimento na juventude e adultez. Também aprofunda a discussão sobre o papel da universidade como propulsora de desenvolvimento adulto. O processo de desenvolvimento é concebido como transformação contínua, na linha do tempo, em que estão inter-relacionados fatores internos e externos, num processo complexo e não linear (Zittoun, 2009).

Partimos da concepção de desenvolvimento humano adulto, marcado pela existência de mudanças ao longo da vida, pelo estabelecimento de regularidades e continuidades, mas

\footnotetext{
${ }^{1}$ Adiante, outros dados que ilustram a escolarização de pessoas com deficiência são apresentados.
} 
também por interrupções e reorientações. Nessa compreensão, o acesso ao ensino superior está ligado ao desenvolvimento humano adulto em uma perspectiva complexa e crítica, oportunizada pela inserção em grupos diferenciados, pela criação de um universo semiótico e por consequentes processos inter e intrapsicológicos (Marinho-Araújo, 2009). O desafio deste estudo é compreender os processos de significação dos estudantes com deficiência em sua experiência acadêmica, ao conhecer a estrutura, o contexto e as narrativas autobiográficas desses estudantes, refletindo assim as potencialidades e fragilidades do sistema inclusivo.

Com isso, a investigação aponta as seguintes problematizações: como têm sido dadas condições para a inclusão de alunos com deficiência no ensino superior? Como os estudantes percebem suas condições de participação no processo educacional? As IES têm garantido condições de permanência qualificada dessa parcela de estudantes? Como ocorrem tais processos?

Na busca por interpretações para o fenômeno, são necessários esforços investigativos que busquem compreender a inclusão, conhecer as condições que a favorecem e ainda, entender como fazê-la viável, tendo em vista as características de cada contexto e nível escolar (Martínez, 2007). Consideramos ainda que compreender os processos de desenvolvimento experienciados pelos jovens com deficiência na universidade pode ser importante para a elaboração e implementação de políticas públicas educacionais mais efetivas e adequadas.

É nesse aspecto que a psicologia tem se feito importante colaboradora das reflexões para a inclusão, ao se constituir como campo disciplinar voltado à discussão sobre a construção de uma cultura de direitos humanos. Estudos e ações da psicologia tem contribuído com a educação na disseminação de valores como inclusão, justiça e igualdade de oportunidades, possibilitando o exercício de cidadania aos estudantes — particularmente os que têm alguma deficiência. 
A proposta desta pesquisa envolve compreender os sistemas de significados institucionais e as trajetórias de desenvolvimento pessoal de estudantes com deficiência autodeclarada, mediados pelo cotidiano das práticas na universidade. Para isso, o estudo discute a inclusão de sujeitos com deficiência no ensino superior, a partir de duas dimensões: uma que considera as condições institucionais e sociais da universidade para o desenvolvimento de trajetórias acadêmicas; e uma que interpreta, com base em informações obtidas em narrativas de entrevistas, os significados que compõem as trajetórias de desenvolvimento de estudantes com deficiência na universidade. O estudo discute a realidade de uma instituição de ensino brasileira e três instituições portuguesas, visitadas quando participei de um programa de doutorado sanduíche no exterior, no período de agosto a dezembro de $2014^{2}$.

A organização do texto é a seguinte: fundamentação teórica, objetivos da pesquisa, referencial metodológico, resultados e discussão, considerações finais, referências bibliográficas, apêndices e anexos.

${ }^{2} \mathrm{O}$ estágio doutoral (doutorado sanduíche) foi realizado na Universidade do Minho, com apoio da Coordenação de Aperfeiçoamento de Pessoal de Nível Superior (Capes). 


\section{FUNDAMENTAÇÃO TEÓRICA}

\section{DEFICIÊNCIA E INCLUSÃO EDUCACIONAL: ASPECTOS HISTÓRICOS, CONCEITUAIS E LEGAIS}

O fenômeno da inclusão de estudantes com deficiência no ensino superior é recente, como buscamos delinear na Introdução. Trata-se de um indicador já consolidado em ações para inclusão educacional efetuadas em etapas anteriores da carreira escolar. Neste capítulo, abordamos os seguintes temas: a deficiência e seus significados; e a inclusão escolar e suas bases legais e normativas. Partimos de uma abordagem histórica das construções em torno do tema da deficiência e explicamos como elas afetam as práticas de educação especial, e ainda o sistema escolar inclusivo. Em seguida, a discussão se volta para os conceitos relacionados ao tema.

\subsection{Construção histórico-social da deficiência e das práticas de educação especial}

$\mathrm{Na}$ Antiguidade, as pessoas com deficiência representavam um fardo para seu grupo. Como o trabalho baseava-se na obtenção de meios de subsistência, principalmente pela caça, que exigia habilidade e força, as pessoas com deficiência não se enquadravam no modelo social e, portanto, eram abandonadas. Em alguns contextos, a exemplo de grupos nômades primitivos, a deficiência era entendida como a presença de maus espíritos e, por isso, a pessoa 
deficiente era considerada uma ameaça social e/ou um empecilho, que precisava ser banida (Gugel, 2007).

Há relatos de que pessoas com deficiência também eram abandonadas ou mortas. Aqueles que apresentavam limitações severas passavam a viver à margem da sociedade e definhavam até a morte, ou, ainda, eram exterminados. Persistia a representação da deficiência como presença de maus espíritos, e assim crianças com deficiência física eram assassinadas, enquanto as nascidas com outras formas de deficiência sofriam abandono (Gugel, 2007).

$\mathrm{Na}$ antiga Mesopotâmia, crianças com deficiência eram vistas como objeto de desprezo dos deuses. Na Grécia, eram inclusive abandonadas em locais desertos para morrerem, como forma de ser devolvidas a eles. Valle e Connor (2014) descrevem que, na Bíblia — texto de influência mundial, dadas as distintas religiões que a reconhecem como texto fundamental e base doutrinária $^{3}$ —, as manifestações da deficiência comumente estavam associadas à presença do mal, e a pessoa precisava ser curada para se salvar ou como forma de glorificar Deus. Os autores apontam, ainda, que muitas crenças contribuíram para destacar a representação de inferioridade, condição subumana ou incompletude associada à pessoa com deficiência. Essa realidade contribuiu, historicamente, para gerar marginalização e levou à disseminação da crença de erradicação como alternativa legítima.

Na Idade Média, nota-se uma pequena mudança no âmbito dos valores, quando comparada à Antiguidade. Nesse momento, as pessoas que detinham alguma deficiência deixaram de ser assassinadas e passaram a ser acolhidas como objeto de práticas de caridade, sob a influência da religião, ainda que continuassem segregadas socialmente. A segregação

\footnotetext{
${ }^{3}$ A penetração da Bíblia em religiões de diferentes bases doutrinárias converte-a em importante fonte de representações sociais e orientações práticas sobre modos de vida — e, também, sobre concepções relacionadas à deficiência.
} 
seguia encontrando respaldo na representação da deficiência como castigo de Deus, ou feitiçaria.

Já na Idade Moderna, com a valorização do homem relacionada ao Humanismo, as pessoas com deficiência passaram a ser vistas como doentes e a ocupar asilos, conventos e albergues: eram isoladas da sociedade, em instituições sem qualquer caráter educativo ou de atendimento especializado (Miranda, 2003). Havia, ainda, casos em que tais pessoas eram separadas de suas famílias para serem ridicularizadas e, assim, servirem de diversão social (Machado \& Nazari, 2012).

No século XVIII, algumas formas de deficiência começaram a ser objeto de solidariedade, ou compaixão (Machado \& Nazari, 2012), dando origem a práticas assistencialistas, que tinham como interesse corrigir ou compensar os limites, na perspectiva de educar e reabilitar. Algumas deficiências passaram a ser tratadas como doenças, e inauguraram-se hospitais e escolas para cegos e surdos. A primeira instituição voltada à educação de "surdos-mudos" foi fundada em Paris em 1770. Em 1784, foi criado o Instituto Nacional de Jovens Cegos, também em Paris. O código Braille surgiu nesse instituto, em 1829, a partir da adaptação, por Louis Braille, de outro código, que era utilizado para a escrita noturna militar.

No século XIX, a história da deficiência pode ser contada como o período denominado de institucionalização parcial, que, segundo Aranha (1995), se caracterizou pela ênfase na inserção dos estudantes em escolas especiais, ou em classes especiais dentro de escolas públicas. No referido período, surgiram instituições para atender as pessoas com deficiência, num sistema de acolhimento parcial, em que os indivíduos eram alocados em espaços segregados e recebiam atendimento específico. O modelo de institucionalização parcial perdurou pelo século XIX e adentrou parte do século XX. 
Só em meados do século $\mathrm{XX}$ foram percebidas iniciativas que resultaram na conquista de direitos para as pessoas com deficiência, com tentativas de integração (Mazzota, 1996). De forma geral, embora se avançasse em práticas sociais menos cruéis, a separação, a estigmatização e a desvalorização marcaram a história da deficiência em algumas sociedades antigas, assim como no mundo ocidental. O processo não foi diferente no Brasil, onde práticas semelhantes estiveram presentes na história da educação especial, como discutido na seção a seguir.

\subsection{Transformações das abordagens e práticas para a deficiência no Brasil}

Ao tomar o Brasil por objeto de análise histórica, Machado e Nazari (2012) identificam processos similares aos que aconteceram em países da Europa e nos Estados Unidos, com a diferença de que lá permaneceram vigentes até o século XVII, e aqui se estenderam por mais tempo. Podemos argumentar que, em nosso país, o predomínio dos dispositivos de exclusão da pessoa com deficiência se estendeu até a década de 1950. Até então, os poucos conhecimentos relativos às deficiências ficaram restritos aos meios acadêmicos e, assim, eram escassas as opções de atendimento às pessoas com deficiência (Machado \& Nazari, 2012).

No período do Império (de 1822 a 1889, com a instauração da República), enquanto o modo de produção estava baseado num modelo rural, de trabalho braçal, o acesso à educação era restrito entre todos os segmentos sociais, e esse panorama incluía as pessoas com deficiência. Conforme o modo de produção se tornava mais especializado, a educação começava a representar uma necessidade. A partir desse período, a educação para a população passou a ser organizada em ações e políticas estatais. Entretanto, as políticas ignoravam direitos sociais de pessoas com deficiência, porque o tema ainda não estava colocado pela 
sociedade brasileira. Assim, perpetuou-se a segregação aos indivíduos com deficiência, que por muitos anos foram mantidos excluídos de acesso aos direitos sociais.

No século XIX, tomando por modelo experiências realizadas por países da Europa e pelos Estados Unidos, surgiram no Brasil serviços organizados de atendimento a surdos, cegos, deficientes mentais e deficientes físicos, embora ainda marcados pelo caráter assistencial e fruto de iniciativas isoladas (Mazzota, 1996). As primeiras iniciativas de atendimento às pessoas com deficiência se constituíram, à época, a partir de um modelo médico assistencial, em que as instituições especializadas ofereciam atendimento pedagógico ou médico-pedagógico.

Uma das instituições especializadas foi fundada em Salvador (BA), oferecendo atendimento médico no Hospital Juliano Moreira, em 1874. Já a outra, de ensino regular, funcionava na Escola México, no Rio de Janeiro (RJ), em 1877, voltada particularmente às pessoas com deficiência física ou visual (Machado \& Nazari, 2012). Os registros sobre o tipo de atendimento dessas instituições não apontam se o trabalho poderia ser considerado educacional. Entretanto, é possível destacar que a compreensão vigente era da deficiência como doença (Jannuzzi, 1992). Tal concepção e a adoção do modelo médico apoiavam a visão de deficiência não como uma condição, mas como patologia a ser tratada, minimizada ou mesmo exterminada. O modelo médico se baseava em ações e princípios clínicos, o que marcou fortemente a significação da deficiência como algo a ser curado, tratado, suprimido — e não como uma condição existencial da pessoa. De certa maneira, o modelo médico da deficiência não foi superado e se perpetua até os dias atuais (Valle \& Connor, 2014).

Uma das propostas que se destacou nesse momento foi o denominado modelo médicopedagógico. O modelo em questão nutria uma concepção reparadora, com foco em corrigir e/ou curar as deficiências e assim homogeneizar a sociedade, por estabelecer como norma a 
ausência de diferenças — por exemplo, as que eram definidas pela condição de deficiência. A perspectiva reparadora era focada em ações como a inspeção escolar para a identificação e a proposição de um modelo de "educação para os estudantes que eram considerados anormais" em termos de inteligência (Jannuzzi, 1992).

Na mesma época, surgiu outra vertente, denominada psicopedagógica. A abordagem psicopedagógica era caracterizada, naquele cenário, como tendo foco em uma conceituação mais precisa para o que era considerado anormalidade. Com ênfase no diagnóstico feito por meio de escalas psicológicas, o objetivo era orientar decisões quanto ao encaminhamento às escolas ou classes especiais. O modelo baseava-se nas concepções de normalidade e anormalidade, com caráter notadamente normatizante e excludente, e encontrava nas abordagens clínico-terapêuticas e nos testes psicométricos a orientação para práticas escolares voltadas aos alunos com deficiência. Também essa vertente ainda hoje influencia práticas na educação especial que guardam esse caráter segregador (Machado \& Nazari, 2012).

Pelas características dos modelos vigentes até meados do século XX, é possível inferir que o foco encontrava-se em identificar, classificar e, assim, adotar estratégias para lidar com as deficiências e os déficits apresentados pelos estudantes. Com essa postura, o atendimento servia mais como elemento controlador e terapêutico e menos como educação.

Em meados do século XX, surgiram as Associações de Pais e Amigos dos Excepcionais (Apaes), associações da sociedade civil, filantrópicas, de caráter cultural, assistencial e educacional. O trabalho das Apaes é voltado à educação e reabilitação, com profissionais das áreas de educação (professores e pedagogos) e saúde (enfermeiros, psicólogos e fisioterapeutas). A iniciativa foi pioneira, trouxe avanços à educação de crianças, inicialmente, e a seguir também de adolescentes e jovens, com deficiências ou atrasos intelectuais, dando origem a ações que se mantêm até os dias atuais, segundo dados da 
Federação das Apaes (APAE, 2012). A associação conta com mais de duas mil unidades no país. Ela é citada nesta tese por se constituir como organização da sociedade civil com maior história acumulada, a única no país a desenvolver um trabalho contínuo no atendimento às pessoas com deficiência intelectual.

Nos anos que se seguiram ao final da Segunda Grande Guerra (pós-1945), ocorreram diversas conquistas, que vêm sendo consolidadas desde então. O desenvolvimento da cultura de direitos humanos, assim como o crescente reconhecimento da diversidade como condição humana, contribuiu para a elaboração e efetivação de um modelo de educação escolar que concedesse mais espaço aos alunos com deficiência (Miranda, 2003), embora ainda coerente com o paradigma da normalização decorrente do modelo médico de deficiência.

Nesse mesmo período, surgiram os primeiros tratados, convenções e mobilizações internacionais que influenciaram a proposição de um modelo educacional inovador para os alunos com deficiência, sendo as pioneiras a Declaração Universal dos Direitos Humanos (1948) e a Declaração Universal dos Direitos da Criança (1959). Esses documentos foram importantes por destacarem, de início, a grande importância atribuída à educação como ferramenta emancipatória e transformadora da sociedade; a crença na igualdade de oportunidades como meio de promoção da justiça social e desenvolvimento; e o reconhecimento de direitos das pessoas, bem como as responsabilidades do Estado na garantia desses direitos.

O impacto dessas iniciativas repercutiu nos modelos de educação especial de vários países, entre eles, o Brasil. Surgiu, assim, o modelo denominado "Integração das pessoas com deficiência ao ambiente escolar" (Miranda, 2003). Este propunha a matrícula dos alunos com deficiência em escolas comuns, depois de terem sido preparados em escolas especiais e desde que tivessem adquirido condições adequadas ao bom desempenho acadêmico na escola 
regular. Como paradigma para a educação especial, a Integração visava ampliar a garantia de direitos e representava uma alternativa para inserir as pessoas com deficiência em espaços sociais diversos e, em especial, na escola (Duarte, Rafael, Filgueiras, Neves \& Ferreira, 2013). Entretanto, aos olhos das concepções éticas hoje vigentes, tratava-se de um modelo que depositava no indivíduo a ser integrado a tarefa do desenvolvimento prévio das capacidades e habilidades básicas requeridas para a inserção bem-sucedida. O sucesso da integração requeria que a pessoa pudesse viver, aprender e trabalhar de forma semelhante aos demais indivíduos (Dias, 2004, 2014).

Para Sassaki (2004), as habilidades requeridas para a integração em classes regulares podiam ser trabalhadas quer nas próprias escolas, em classes especiais, quer em espaços de assistência (centros de reabilitação, oficinas protegidas de trabalho, clubes recreativos). É importante destacar que o modelo de integração se baseava em concepções adaptativas, seletivas e normatizantes da relação pessoa-sociedade, de acordo com uma visão orgânica e positivista da dinâmica social (Mantoan, 2008). Em outras palavras, para se integrar à escola, o indivíduo precisava encontrar-se munido de um repertório social, cultural e cognitivo que o apoiassem, de modo a assemelhar-se aos demais sujeitos, adaptando-se à escola e à sociedade. Por isso, a maior crítica ao modelo de Integração centra-se na sua natureza classificatória e, portanto, excludente (Dias, 2004; Machado \& Nazari, 2012).

Entre o final dos anos 1980 e o início dos anos 1990, iniciou-se uma nova era das relações políticas entre grupos e culturas, com mudanças ideológicas decorrentes de fatos como o fim da Guerra Fria e a queda do muro de Berlim. Nesse período proliferou, no Brasil e no mundo, uma série de movimentos sociais anticolonialistas e de afirmação de minorias, que tiveram impacto positivo sobre o direito à educação. Documentos internacionais, como a Declaração de Jomtien (1990), a Declaração de Salamanca (1994), a Convenção da Guatemala 
(1999) e, adiante, a Declaração de Montreal (2004), favoreceram condições culturais para a reflexão, cada vez mais crítica, acerca dos valores vigentes na sociedade até então e do modo como eles se refletiam na educação especial.

As análises possibilitaram que, no fim dos anos 1990, ganhasse vigor um modelo de educação a que se denominou Inclusão Escolar. O paradigma inclusivo representou uma tentativa de romper com o modelo anterior, pautado na integração. A principal novidade foi retirar do indivíduo a responsabilidade por possuir habilidades que o tornassem apto a se integrar aos grupos sociais (Dias, 2004; Mantoan, 2008) e transferir para as instituições da sociedade a responsabilidade ética de promover mudanças na sua cultura institucional. A finalidade era acolher as diferenças e diversidades humanas, incluindo-se nesse rol as deficiências.

A proposta da Inclusão Escolar resultou de uma série de movimentos e reflexões internacionais sobre o papel da escola como instituição social, promotora de igualdade de condições sociais para pessoas com diferentes pontos de partida, quando consideradas as condições de desenvolvimento e aprendizagem (Anache, 2009; Carvalho, 2006; Fleith, 2011).

O paradigma da inclusão é amplo e não engloba apenas os considerados com deficiências. Ele visa ultrapassar a condição de exclusão que pode advir quando a sociedade e a escola, de modo particular, não se orientam por uma perspectiva ética e respeitosa à diversidade (Falsarella \& Silva, 2002; Mantoan, 2008).

Cabe destacar que a intenção dos documentos internacionais e nacionais, ao proporem o paradigma inclusivo, era abrangente: incluir todos aqueles em situação de exclusão, seja por deficiência física, intelectual, sensorial, seja por outras situações relacionadas à reprodução das desigualdades. As possibilidades inclusivas ainda se voltavam a atender os alunos em situação de fracasso escolar, os marginalizados por razões raciais, culturais, ou quaisquer 
outras capazes de afetar seu desenvolvimento social, emocional e intelectual (Machado \& Nazari, 2012).

Apesar disso, muitos pontos desses documentos limitaram-se a estabelecer condições gerais a serem atendidas pelas escolas para acolher as pessoas com deficiências, incluindo aspectos de acessibilidade e adaptação curricular. Assim, convencionou-se, no contexto escolar, denominar "inclusão" os procedimentos voltados ao atendimento às pessoas com deficiência, conforme aparece na legislação referente ao tema. De acordo com o artigo 24 do Decreto n. ${ }^{\circ}$ 6.949/2009, para caracterizar-se como inclusiva, uma escola deve, no mínimo, conter as condições físicas, pedagógicas e relacionais para o acesso, a permanência e a plena participação do estudante com deficiência.

Nos últimos vinte anos, foi possível verificar avanços nas práticas que materializam o paradigma em alguns contextos, como os anos iniciais de escolarização, nos quais se destacou a ampliação do atendimento a estudantes com deficiências e necessidades educacionais especiais. Entretanto, nem todos os espaços educacionais possuem condições adequadas de acessibilidade e a demanda de vagas para esses estudantes não é plenamente atendida, como costuma ocorrer nos anos finais da educação básica e no ensino superior (Marinho-Araújo, 2009, 2011; Martínez, 2007). Mesmo naqueles contextos em que as práticas inclusivas estão mais amadurecidas, muito há por ser feito quanto a qualificar as condições de permanência e desenvolvimento das pessoas no sistema educacional inclusivo.

A análise sobre os direitos que foram alcançados, como a garantia de inserção nos espaços regulares e de vaga nas redes públicas de ensino na educação básica, reforça a ideia de que muito já foi feito. Contudo, ainda há muito por construir (Mitler, 2003; Valle \& Connor, 2014), principalmente, para qualificar o aproveitamento da experiência escolar e potencializar o desenvolvimento global do sujeito. Observamos que, quanto mais se avança no nível de 
ensino, mais as demandas de qualificação se acumulam. O desafio, para o momento, é de melhor compreender o processo inclusivo como um todo, o que envolve problematizar as práticas inclusivas instituídas e promover sua qualificação em todos os níveis e modalidades de ensino. Na busca pela compreensão da inclusão, o enfoque da próxima seção recai sobre as significações e a normatização da deficiência.

\subsection{Desdobramentos dos processos históricos sobre as significações e a normatização da deficiência}

Nesta seção, discutimos os conceitos relacionados à deficiência e as alterações nas definições, que foram se constituindo historicamente.

\subsubsection{Diretrizes nacionais e internacionais: do meio médico às práticas educacionais}

Como ponto de partida, exponho as abordagens teóricas e filosóficas que contribuem para o entendimento de conceitos relacionados à deficiência, às necessidades educacionais especiais e à inclusão presentes em documentos normativos e técnicos nacionais e internacionais, apontando as alterações sofridas ao longo das últimas duas décadas.

Há uma série de definições de deficiência. São termos, em geral, de origem médica, como os que integraram a Classificação Internacional de Deficiências, Incapacidades $e$ Desvantagens (CIDID), datada da década de 1980 e hoje considerada obsoleta. Durante pelo menos uma década, enquanto esteve em vigor a Integração Escolar, o meio educacional tomou emprestado do meio médico essa classificação e, para definir deficiência, aderiu a conceitos nosográficos como doença ou distúrbio, incapacidades, desvantagens. Estabelecendo ligação 
entre a concepção médica da deficiência e a Integração, percebemos como os aspectos normativos e históricos estão em relação e se fertilizam mutuamente na construção de significados, que, por sua vez, norteiam e influenciam práticas. Nessa compreensão, a deficiência era conceituada como a repercussão imediata de uma doença que incidia sobre o corpo, impondo uma alteração estrutural ou funcional no nível tecidual ou orgânico.

A incapacidade, segundo a Organização Mundial de Saúde (OMS), é definida como um efeito secundário à deficiência, caracterizada pela redução ou falta de capacidade de realizar uma atividade num padrão considerado normal para o ser humano. Já a desvantagem é um conceito sociológico, que envolve a comparação entre indivíduos segundo critérios de normalidade. A desvantagem representa os impedimentos resultantes de uma deficiência ou incapacidade, que limitam o indivíduo no desempenho de uma atividade, levando-se em consideração a idade, o sexo e os fatores socioculturais. A OMS trata, ainda, do termo limitação, empregado para se referir àquilo que causa grande impacto nas atividades de vida diária do indivíduo, como resultado da deficiência (OMS, 2001).

Após uma década, devido às críticas sofridas, a CIDID deu lugar à Classificação Internacional de Incapacidade, Funcionalidade e Saúde, a CIF (MEC, 2011). A CIF representou uma tentativa de reformular as concepções e promover a compreensão da deficiência não apenas na sua dimensão biológica, mas também nas dimensões psicobiossociais, ao introduzir conceitos como limitações de atividade e restrição de participação. Por limitações de atividade entendem-se as dificuldades apresentadas pela pessoa para a execução de atividades, que podem variar em termos de quantidade e qualidade, em comparação com as pessoas sem deficiência. Já as restrições são compreendidas como os problemas que um indivíduo pode enfrentar nas situações cotidianas de vida, tendo como parâmetro para a restrição as atividades esperadas de um indivíduo sem deficiência. No meio 
educacional, tal abordagem se relacionou ao período em que emergiu o paradigma da Inclusão Escolar (OMS, 2001).

É importante também refletir sobre a conceituação que define as pessoas em relação às deficiências e necessidades especiais nos documentos normativos e na literatura educacional. Essa temática também sofreu alterações no discurso da educação, que levaram a mudanças nas significações legais e em outros campos. Em 2003, a normatização do Programa Educação Inclusiva: Direito à Diversidade contribuiu de modo decisivo para a disseminação do termo Portador de Necessidades Educacionais Especiais. A redação do documento está apresentada da seguinte forma: "são definidos como alunos portadores de necessidades educacionais especiais aqueles que apresentarem necessidades próprias e diferentes dos demais alunos no domínio das aprendizagens curriculares correspondentes à sua idade, requerendo recursos pedagógicos e metodologias educacionais específicas” (MEC, 2005, p. 43).

Em 2005, o Ministério da Educação (MEC) instituiu uma classificação das deficiências que as agrupava em deficiência mental, visual, auditiva, física e múltipla. Tratava-se de um sistema mais abrangente, que incluiu as condutas típicas e, ainda, a superdotação/altas habilidades. A nova classificação não apenas refletiu os desenvolvimentos do campo de pesquisas sobre as deficiências e suas respectivas possibilidades educacionais, como atendeu ao propósito de formalizar o papel da escola na educação das pessoas com distintos modos de desenvolvimento e aprendizagem.

A adoção, pelo MEC, de ações para a crescente sistematização e ampliação do atendimento aos alunos com deficiência pode ter influenciado o aparecimento de um maior número de pesquisas na área. Entretanto, a produção ainda é pequena, dada a grande dimensão territorial do país e a quantidade de programas de pós-graduação. Para ilustrar a distribuição e o crescimento no campo das pesquisas, composto por dissertações e teses sobre deficiência, 
apresento o Quadro 1, a seguir. São 69 produções, realizadas entre o período de 2000 a 2013, cuja distribuição se compõe de 57 dissertações de mestrado e 12 teses de doutorado.

Quadro1 - Pesquisas acadêmicas sobre deficiência no ensino superior (2000-2013)

\begin{tabular}{|c|c|}
\hline ANO & QUANTIDADE DE TRABALHOS \\
\hline 2000 & 0 \\
\hline 2001 & 1 \\
\hline 2002 & 2 \\
\hline 2003 & 1 \\
\hline 2004 & 0 \\
\hline 2005 & 5 \\
\hline 2006 & 7 \\
\hline 2007 & 8 \\
\hline 2008 & 8 \\
\hline 2009 & 9 \\
\hline 2010 & 10 \\
\hline 2011 & 5 \\
\hline 2012 & 9 \\
\hline 2013 & 4 \\
\hline
\end{tabular}

\section{TOTAL}

Fonte: Elaboração da pesquisadora

Em 2009, o Decreto n. 6.949 trouxe uma nova abordagem do tema, marcado pelo enfoque contextual e relacional, ao apontar, em seu preâmbulo, que "a deficiência resulta da 
interação entre as pessoas com deficiência e as barreiras atitudinais e ambientais que impedem sua plena e efetiva participação na sociedade em igualdade de oportunidades com as demais pessoas" (Brasil, 2009). Aqui a mudança paradigmática é marcante, pois desloca o problema da pessoa para as relações e interações, contribuindo para a superação do enfoque médico, organicista e nosográfico.

Temos, atualmente, recente terminologia de deficiência adotada pelo Ministério da Educação em sua instrução normativa Marcos Político-Legais da Educação Especial na Perspectiva da Educação Inclusiva (MEC, 2011). No documento, a deficiência é caracterizada como impedimento de longo prazo, que pode restringir a participação do indivíduo no meio social. Essa compreensão está expressa de modo mais completo na Lei n. ${ }^{\circ} 12.470$, de 31 de agosto de 2011, que define "pessoa com deficiência" como aquela que tem impedimentos de longo prazo (pelo menos dois anos) de natureza física, mental, intelectual, ou sensorial (Brasil, 2011). Tais impedimentos podem obstruir sua participação plena e efetiva na sociedade, em igualdade de condições com as demais pessoas.

Um conceito importante, que merece ser apresentado e distinguido do conceito de deficiência, são as Necessidades Educacionais Especiais (NEE). Incluem-se nessa categoria todas as condições permanentes ou transitórias, não apenas as que são caracterizadas como deficiências, que afetam as possibilidades, os ritmos e as especificidades dos estudantes em seu processo de escolarização. Quando se fala de NEE, incluem-se os alunos com deficiências sensoriais, motoras e intelectuais, com altas habilidades, com transtornos neurológicos, ou outros que afetem a comunicação e o desenvolvimento global (MEC, 2005; Sampaio, 2010), mas não somente eles.

Embora não sejam foco do presente trabalho, também estão enquadrados como tendo necessidades educacionais especiais os estudantes com impedimentos temporários, os 
estrangeiros, os indígenas, os que estão em distorção idade-série no processo escolar, entre outros. O acolhimento de todas essas especificidades pela escola favorece que os alunos, de com deficiências ou não, possam encontrar ali os meios para o melhor desenvolvimento de suas habilidades cognitivas e sociais (Fischer, 2014; 2011; MEC, 2011; Sampaio, 2010; Valle \& Connor, 2014).

A deficiência pode implicar diferenciadas características físicas, motoras ou sensoriais de longo prazo. Tais características podem levar a condições específicas no modo como o indivíduo interage com a sociedade, que, em geral, encontra-se despreparada para acolher e atender as peculiaridades da pessoa com deficiência. Como efeito, a deficiência se materializa sob a forma dos obstáculos e dificuldades (MEC, 2011; Sampaio, 2010; Valle \& Connor, 2014; Vygotsky, 1995).

Há uma interseção entre os conceitos de deficiência e necessidades educacionais especiais, pois algumas deficiências implicam necessidades educacionais especiais maiores e mais específicas, enquanto outras, menos. Em alguns casos, as deficiências nem sequer implicam necessidades, assim como algumas necessidades especiais, tal como caracterizadas anteriormente, não se ligam à presença de deficiência.

Contudo, chamamos a atenção para uma questão que emerge na contemporaneidade, decorrente das vicissitudes da vida, e contribui para ampliar o escopo de condições que podem ser caracterizadas como necessidades educacionais especiais. São exemplos dessas novas condições, cuja ocorrência na população parece crescente: o Transtorno do Déficit de Atenção (com ou sem associação com a hiperatividade), os transtornos de humor, o uso de drogas lícitas e ilícitas, doenças como psoríase, depressão e lúpus, e doenças de origem neurológica. Essas condições geram necessidades educacionais especiais e, assim, desafiam as 
universidades a desenvolver estratégias mais personalizadas de ensino, que superem dispositivos homogeneizantes e respondam às demandas dos estudantes.

Ilustra a diferença no uso dos termos deficiência e necessidades educacionais especiais o estudante com altas habilidades. Esse estudante apresenta uma necessidade educacional especial, uma especificidade a ser acolhida e atendida pela escola para propiciar seu desenvolvimento, mas não uma deficiência. Em síntese, há casos e características a serem consideradas singularmente, para cada indivíduo, o que nos faz acreditar que o uso dos termos deficiência e necessidades educacionais especiais em conjunto ou como sinônimos pode não representar a realidade vivenciada pelos estudantes, bem como suas singularidades e demandas em relação à escola ou sociedade. Não é possível afirmar que, em todos os casos, as deficiências geram necessidades educacionais especiais, ou, em situação contrária, as necessidades educacionais especiais decorrem das deficiências.

De forma geral, as definições aqui apresentadas são amplas e diferentes. Elas colocam em exposição diversas condições subjetivas e de grupos, como limitações, restrições e impedimentos. Além disso, destacam aspectos negativos da deficiência, levando a adjetivações que generalizam as baixas condições de vida das pessoas, de forma a destacar as dificuldades e desvantagens, que se tornam mais evidentes que a própria pessoa.

A deficiência foi concebida como um problema que tornava a pessoa diferente e inferior. Em termos éticos, transformar uma característica pessoal ou de um grupo em problema é um dispositivo que contribui para subalternizar o outro, posicionando-o em lugar social hierarquicamente desvantajoso. O adjetivo "especial", utilizado para qualificar as necessidades das pessoas com deficiência, também é problemático. O termo é pejorativo, contribuindo para identificar a deficiência com algo negativo, como incapacidade, desvantagem, anormalidade, estado limitante e, geralmente, visto como irreversível. 
Percebemos a força que os conceitos tidos como científicos ou legais podem ter e seu papel no agravamento da exclusão. Ademais, os efeitos das representações decorrentes da segregação se estendem, contribuindo para a estigmatização e o preconceito nos grupos com os quais o indivíduo interage, bem como para a negação da condição primeira de indivíduo, cidadão e sujeito de direitos (Goffman, 1988).

Pensar a deficiência a partir de conceituações divergentes amplia a compreensão da existência de forças antagônicas que envolvem o tema. De um lado, a deficiência é definida como uma incapacidade permanente, conceito intrincado de valores culturais que consideram a dificuldade, a incapacidade, a limitação como sinônimos de deficiência. De outro, numa abordagem mais atual e social, a deficiência é compreendida como perda de uma funcionalidade, um impedimento relacional, que pode se manifestar nas situações de vida. Esses impedimentos dependem do contexto e suporte social e podem ser, inclusive, superados por meio de adequação, suporte, reabilitação. Nesse sentido, a deficiência é resultado do encontro entre pessoa e meio social, e define-se em termos das condições que o contexto oferece aos indivíduos que se encontram em condições desvantajosas.

\subsubsection{Inclusão: um conceito em contínuo delineamento}

Atualmente, a inclusão é definida por um conjunto de metodologias e estratégias que visam atender em espaço regular de ensino, prioritariamente, os alunos com deficiência e/ou necessidades educacionais especiais. Seu princípio geral é a busca por privilegiar o desenvolvimento de potencialidades e a aprendizagem significativa dos alunos, independente de suas condições prévias, e considerando suas condições específicas (Fischer, 2014; Gonçalves, 2010; Valle \& Connor, 2014). Albuquerque e Martínez (2012) ressaltam que o 
paradigma da inclusão escolar objetiva construir uma escola onde todos possam usufruir e beneficiar-se de um ensino de qualidade. Propõem uma educação com reais possibilidades de aprendizagem, respeito à diferença e promoção dos direitos humanos.

As terminologias que definem a educação inclusiva têm avançado ao destacar a importância de um ensino de qualidade e das condições de permanência para os estudantes. Essa compreensão é fruto do denso processo histórico que desenhou e continua a delinear o conceito e as práticas de inclusão nos últimos vinte anos. Trabalhos muito recentes, de autores como Valle e Connor (2014), Mantoan (2013) e Silva (2014), apontam que a compreensão hoje vigente baseia-se em um novo referencial para definir a deficiência, o qual, por sua vez, compõe um modelo social para o atendimento aos estudantes. O modelo social fundamenta-se em orientações que enfatizam o caráter social e relacional da deficiência, abandonando os enquadres organicistas ou individualistas da questão. De acordo com essas orientações, pessoas com deficiência têm o direito de vida plena, sendo dever da sociedade se organizar para acolher e atender suas necessidades. Tal abordagem é especialmente influenciada por um grupo de estudos sobre deficiência denominado Grupo de Washington.

O Grupo de Washington nasceu do Movimento de Direitos das Pessoas com Deficiência e de Vida Independente, por ocasião da Conferência Perspectivas Globais sobre Vida Independente para o Próximo Milênio, realizada em Washington DC, Estados Unidos, em 1999 (Sassaki, 2004). A conferência de Washington teve como principal desdobramento a formulação e divulgação da Declaração de Washington, documento que continha orientações para a promoção de vida independente e convidava as pessoas com deficiência à participação no Movimento de Direitos das Pessoas com Deficiência e de Vida Independente. O tema trabalhado pelo grupo foi retomado na Convenção da Organização das Nações Unidas (ONU) sobre os Direitos da Pessoa com Deficiência, realizada em 2008, que destacou o dever do 
Estado de promover, proteger e assegurar o exercício pleno e equitativo de todos os direitos humanos e das liberdades fundamentais por todas as pessoas com deficiência e promover o respeito pela sua dignidade.

Emerge a necessidade de mudanças nas atitudes e no próprio sistema educacional, que deve se mover pela constante reavaliação e reformulação dos trabalhos (Valle \& Connor, 2014). Também se faz necessária a desconstrução de modelos de "normalidade", que acabam por excluir aqueles que não se encaixam a eles, a fim de romper com a segregação. A compreensão da diferença como condição da existência humana (Mantoan, 2008) é um valor a ser incorporado a todos os cenários sociais se queremos uma sociedade ética. Atitudes e valores que sustentam a segregação e as representações negativas da deficiência a descrevem como, por exemplo, perda pessoal, incapacidade, inferioridade e, assim, tornam a pessoa foco de atitudes de tolerância, condescendência e benevolência (Plestch, 2010; Valle \& Connor, 2014).

Em parte graças às críticas e de acordo com proposições e reflexões teóricas, a designação atribuída às pessoas com deficiência ao longo dos anos foi ganhando outras formas. Surgiram termos como aluno com necessidade educacional especial (ANEE), suprimindo assim o termo portador, ou ainda, de forma mais atual, a designação pessoa com deficiência (PD), proposta a partir da Convenção sobre os Direitos da Pessoa com Deficiência (2008). Os avanços representam tentativas de diminuir os estereótipos, no entanto, o termo inicial, PNEE, persiste, pois é reconhecido e utilizado em parte da legislação, bem como em documentos emitidos pelos poderes públicos — por exemplo, em alguns editais de concursos públicos, regimento internos e orientações, o que basta para lhe garantir legitimidade.

Mitller afirma que "muitas pessoas, hoje em dia, sentem-se desconfortáveis com o uso continuado de linguagem que está se tornando ofensivamente inapropriada" (2003, p. 31). 
Essa afirmação leva a refletir sobre o poder que os significados construídos podem ter de reforçar estereótipos, atitudes e mesmo preconceitos. Assim, a questão referente às terminologias empregadas para identificar e categorizar as deficiências merece reflexão e revisão conceitual, a fim de minimizar os prejuízos que elas provocam. Vê-se como necessário romper com a fixidez da nossa sociedade, abandonando rótulos e discursos hegemônicos, numa opção por construir uma sociedade aberta ao exercício do reconhecimento e respeito (Pletsch, 2010; Silva, 2014).

No texto desta tese, optamos por usar o termo pessoa com deficiência, também adotado pela OMS. Essa expressão é aqui utilizada em razão de seu caráter mais amplo e relacional, embora estejamos cientes dos cuidados, das distinções e das associações entre os termos, conforme já discutido.

\subsection{Aspectos normativos da educação inclusiva}

No limiar do século XXI, com o advento da globalização e o aumento da interdependência entre os povos, aumentam também o contato e a necessidade de convivência com a diversidade. Para atuar na minimização dos conflitos e na aproximação dos povos, a Organização das Nações Unidas para a Educação, a Ciência e a Cultura (Unesco) propôs a educação como eixo de articulação do desenvolvimento, apontando como necessidades a universalização da educação e das políticas de promoção de educação para a paz (Abenhaim, 2005).

Após análise e constatação de uma realidade educacional desfavorável nos países em desenvolvimento, entre eles o Brasil, surgiram ações voltadas a qualificar os processos educativos. A primeira delas foi a Conferência Mundial sobre Educação para Todos (1990), 
a qual estabeleceu seis metas mundiais para a educação. Essas metas versam sobre a expansão dos cuidados com a infância, em especial, as crianças em situação de vulnerabilidade (meta 1); a garantia de educação básica de qualidade às minorias étnicas e às meninas (meta 2); a equidade no acesso a programas de aprendizagem que atendam às necessidades básicas (meta 3); a melhoria nos níveis de alfabetização de adultos (meta 4); a eliminação das disparidades de gênero na educação primária e secundária (meta 5); e a melhoria geral da educação de modo a alcançar resultados melhores em alfabetização, aritmética e habilidades (meta 6) (Abenhaim, 2005).

Já em 1991, como resultado desse movimento, na Conferência Geral da Unesco, propôs-se a composição de uma comissão internacional para refletir sobre os desafios implicados em educar e aprender no século XXI. A comissão orientou seus trabalhos em princípios de equidade, pertinência e excelência, que reforçam os ideais de uma educação mais justa, com igualdade de oportunidades.

No mesmo período, surgiu um movimento mundial em favor das pessoas com necessidades educacionais especiais, que questionava o modelo de integração escolar em vigor. Com tal preocupação, um grupo se organizou para reconhecer o direito das pessoas com necessidades especiais a um novo lugar, na proposta de educação que se estava desenhando. Assim, reuniram-se representantes de 92 governos e 25 organizações internacionais para realizar a Conferência Mundial sobre Necessidades Educativas Especiais, na cidade de Salamanca, em junho de 1994. A partir da Declaração de Salamanca, reforçou-se a necessidade de promover a inclusão de todas as pessoas no meio educacional, incluindo as que tivessem alguma necessidade especial (Abenhaim, 2005). O momento representou um importante esforço pela inclusão. 
Após isso, outras ações foram executadas com a finalidade de avaliar os avanços em educação alcançados pelos países, bem como de promover a inclusão. Destaca-se a reunião, em 2001, dos ministros da Educação da América Latina e do Caribe, que apontou mecanismos para elevar a qualidade da educação. Como resultado da reunião, houve a indicação de buscar os meios para transformar a escola em um ambiente mais flexível e sensível aos desafios de desenvolver e potencializar saberes, práticas e valores sociais mais democráticos (Unesco, 2001). Surgia aí o ideário que culminaria, entre os países signatários (em que se inclui o Brasil), na criação de modelos focados no paradigma da educação inclusiva, uma resposta concreta ao ideal de educação e escola acolhedoras da diversidade, flexíveis e abertas a todos.

Embora esta tese foque a inclusão educacional de alunos com deficiência, há que considerar que o movimento pela inclusão é algo mais amplo, que não se restringe aos indivíduos considerados com deficiência e sequer à educação (Anache, 2007). Este trabalho destaca que o discurso pela inclusão é mais amplo, podendo ser usado em prol de todas as pessoas segregadas socialmente, pelos mais diversos motivos.

Voltando o olhar para o momento atual, importa destacar as incoerências que se seguem à efetivação da Política Nacional de Educação Especial na perspectiva da Educação Inclusiva (2007), momento em que começaram a aparecer evidências importantes de um distanciamento entre os objetivos e a realidade. De início, o paradigma inclusivo, apesar de pretender romper com modelos que primavam pela adaptação e pelo ajustamento individual à escola - e que por isso eram considerados excludentes -, reproduz os mesmos valores que critica (Mantoan, 2013; Pallú, 2013). A concepção de homem ainda obedece às idealizações de perfeição biológica, capacidade e força, entre outras (Mendonça, 2013). Diante de tais idealizações, às pessoas com deficiência são devotadas concepções que se associam à 
incapacidade, fragilidade, diferença. Essas concepções em tensão materializam a exclusão e evidenciam a complexidade e o desafio da criação de processos inclusivos mais efetivos.

O Plano Nacional de Educação (PNE), tanto na edição de 2001 quanto na recémpromulgada, em 2014, apresenta uma meta focada na elevação da qualidade e universalização da educação para as pessoas com deficiência. Entretanto, o plano indica mudanças ainda tímidas para o sistema educacional, que tende a permanecer classificatório, homogeneizante. Se a educação inclusiva tem como premissa o acolhimento da diversidade, mas a escola não atua nesse sentido - ao contrário, trabalha para igualar, normalizar seus estudantes certamente se afasta do ideário inclusivo. E, ao se afastar dele, exclui, elimina possibilidades e nega a diversidade.

A educação especial e a inclusão têm sido contempladas em diversas normas brasileiras. Ao longo dos últimos cinquenta anos, esse tema apareceu em diversos documentos, conforme apresentado no quadro a seguir.

Quadro 2 - Síntese da legislação e dispositivos legais pertinente à educação especial e inclusão escolar

\begin{tabular}{cl} 
LEGISLAÇão & \multicolumn{1}{c}{ CONTEÚDo } \\
\hline Lei n. ${ }^{\circ} 4.024 / 1961$ & Aponta o direito dos excepcionais à educação, preferencialmente, \\
LDBEN & dentro do sistema geral de ensino. \\
\hline Lei n. ${ }^{\circ} 5.692 / 1971$ & Define o tratamento especial para os alunos com deficiências \\
(altera a LDBEN) & físicas, mentais, os que se encontram em atraso considerável \\
& quanto à idade regular de matrícula e os superdotados.
\end{tabular}


Constituição Federal Define a promoção do bem de todos, sem preconceitos de de 1988 origem, raça, sexo, cor, idade e quaisquer outras formas de Artigos $3^{\circ}, 24,205$ e discriminação.

206 Inclui orientações da Convenção sobre os Direitos da Pessoa com Deficiência à Constituição Federal.

Define a educação como direito de todos e dever do Estado e da família, visando ao pleno desenvolvimento da pessoa, a seu preparo para o exercício da cidadania e à qualificação para o trabalho.

Estabelece a igualdade de condições de acesso e permanência na escola, e garante a oferta do atendimento educacional especializado.

Lei n. ${ }^{\circ}$ 9.394/1996 Define a educação especial como modalidade de educação para (LDB) educandos com deficiência, transtornos globais do Artigos 58, 59 e 60 desenvolvimento e altas habilidades ou superdotação.

Assegura aos educandos currículos, métodos, técnicas, recursos e organização específicos; terminalidade específica; professores com especialização adequada; educação especial para o trabalho; e acesso igualitário aos benefícios de programas sociais suplementares.

Estabelece critérios de caracterização das instituições privadas sem fins lucrativos, especializadas e com atuação exclusiva em educação especial, para fins de apoio técnico e financeiro pelo 
Poder Público.

Decreto n. $^{o} \quad$ Estabelece princípios para a integração e o desenvolvimento da 3298/1999 pessoa portadora de necessidades especiais, e enfatiza a atuação complementar da educação especial ao ensino regular.

Resolução Determina que os sistemas de ensino matriculem todos os alunos, CNE/CEB cabendo à escola organizar-se para o atendimento aos educandos n. ${ }^{\circ} 2 / 2001 \quad$ com necessidades educacionais especiais.

(Conselho Nacional

de Educação)

Parâmetros Institui as Diretrizes Curriculares Nacionais para a Educação

Curriculares Especial na Educação Básica.

Nacionais -

Adaptações

Curriculares

Plano Nacional de Destaca que o avanço a produzir na década seria a construção de Educação uma escola inclusiva com garantia de atendimento à diversidade

Lei n..$^{10.172 / 2001}$ humana. Aponta déficits: na oferta de matrículas, na formação docente, na acessibilidade física e no atendimento educacional especializado.

Decreto n. ${ }^{\circ} \quad$ Ratifica a Convenção Interamericana para a Eliminação de Todas 3.956/2001 as Formas de Discriminação.

Resolução CNE/CP Estabelece diretrizes para a formação de professores da educação n. ${ }^{\circ}$ 1/2002 básica, define que as IES devem prever em sua formação docente 
atenção e conhecimento às especificidades dos alunos com necessidades educacionais especiais.

Lei n. ${ }^{\circ}$ 10.436/2002 Reconhece e Língua Brasileira de Sinais (Libras), apoiando seu uso e difusão.

Lei n. $.^{\circ} 10.172 / 2001$ Aprova o Plano Nacional de educação e define metas para a educação na década, entre elas: superação das desigualdades educacionais, melhoria da qualidade do ensino, difusão de princípios de equidade, respeito à diversidade e gestão democrática.

Portaria Aprova diretrizes e normas para o uso, o ensino, a produção e a n. ${ }^{\circ} 2.678 / 2002$ difusão do sistema Braille.

Programa Educação Visa apoiar a transformação dos sistemas de ensino em sistemas Inclusiva: direito à educacionais inclusivos, prevendo formação, garantia de acesso, diversidade oferta de atendimento especializado e acessibilidade.

O Acesso de Alunos Dissemina conceitos e diretrizes mundiais para a inclusão, e com Deficiência às reafirma direitos e benefícios da escolarização de alunos com e Escolas e Classes sem deficiência nas turmas comuns do ensino regular.

Comuns da Rede

Regular

Decreto n. ${ }^{\circ} \quad$ Estabelece normas e critérios para a promoção da acessibilidade 5.296/2004 às pessoas com deficiência ou mobilidade reduzida.

Decreto n. ${ }^{\circ} \quad$ Dá acesso aos alunos surdos à escola, inclui a Libras como 
5.626/2005 disciplina curricular, promove a formação e certificação de professor, intérprete e instrutor. Estabelece o ensino de língua portuguesa como segunda língua e a organização da educação bilíngue.

Decreto n. $^{\circ} \quad$ Estabelece diretrizes do Compromisso Todos pela Educação, 6.094/2007 com base no Plano de Desenvolvimento da Educação (PDE).

Política Nacional de Define as ações da educação especial no país. Educação Especial na Perspectiva da Educação Inclusiva (2007)

Decreto n. $^{\circ} \quad$ Define o acesso a um sistema educacional inclusivo em todos os 6949/2009 níveis de ensino.

Lei n. $.^{\circ} 12.470 / 2011$ Define deficiência.

Lei n. ${ }^{\circ} \quad$ Aprova o Plano Nacional de Educação, com vigência por dez 13.005/2014 anos.

Lei n. ${ }^{\circ} \quad$ Institui a lei brasileira de inclusão da Pessoa com deficiência.

\section{$13.146 / 2015$}

Fonte: Elaboração da pesquisadora

Cabe destacar que o conjunto de normas que regem a educação e, de forma específica, a educação especial carrega aspectos políticos e ideológicos decorrentes de sua construção. Essas são decisões políticas que nascem munidas de uma carga ideológica significativa e que podem ou não retratar os reais interesses e demandas da população. 
No caso da educação especial em perspectiva inclusiva, o Estado realizou iniciativas importantes, que agregaram avanços no que se refere à garantia de acesso à escola. Duas delas, que buscam converter em políticas públicas o alcance de algumas das prerrogativas legais delineadas, são: o Programa Incluir, que apoia a acessibilidade na educação superior, e o Plano Viver sem Limites, com meta de implantar centros especializados de reabilitação para ampliar o acesso e a qualidade dos serviços de saúde a pessoas com deficiência (MEC, 2012) ${ }^{4}$. Entretanto, ainda não se pode falar em êxito, tendo em vista a falta de dados sobre a efetividade das aprendizagens no Brasil (Carvalho, 2006; Silva, 2006).

A legislação é clara ao abordar o dever da escola de acolher todos os sujeitos de direitos. Mas há que se ressaltar, segundo Lima (2006), que o acolhimento não é representado apenas pelo ato formal de garantir a matrícula escolar; ele se complementa na materialização de condições efetivas de realização de potencialidades na escola.

Após discorrer sobre deficiência e inclusão, conduzimos nossa discussão para as questões referentes ao ensino superior. Com isso, avançamos na composição de um quadro teórico que apoia nosso estudo e articula a inclusão no contexto do ensino superior; além disso, abordamos como se dão as trajetórias de desenvolvimento dos indivíduos.

\footnotetext{
${ }^{4}$ Mais informações sobre os referidos programas são acessadas no portal do MEC, em: www.mec.gov.br.
} 


\section{EDUCAÇÃO SUPERIOR: ASPECTOS HISTÓRICOS E PANORAMA ATUAL}

Este capítulo descreve a estrutura organizacional da educação superior, tomando por foco os contextos brasileiro e português. Em seguida, aborda a inclusão nesse nível de ensino. Assim, expõe, tendo como cenário o ensino superior, as demandas e os desafios da construção de práticas inclusivas.

\subsection{Educação superior brasileira: Aspectos históricos}

O ensino superior brasileiro surgiu após a chegada dos colonizadores portugueses ao Brasil, quando se criaram as primeiras escolas superiores. O ideal do ensino superior da época era a formação profissional, logo, era uma formação tecnicista, que se limitava a ensinar a aplicar conhecimentos, sem a preocupação com a produção do conhecimento científico. Um aspecto central era a promoção do controle do Estado sobre o sistema educacional.

Havia a preocupação com a profissionalização, uma vez que os indivíduos eram formados, prioritariamente, para a atuação nos negócios familiares e a descoberta de riquezas e oportunidades. Com isso, podemos afirmar que objetivo do modelo educativo era o ensino para a obtenção de um diploma, que gerava, por sua vez, a ocupação de posições privilegiadas no mercado de trabalho e o prestígio social (Martins, 2002; Olive, 2002; Sampaio, 1991).

O modelo da organização do ensino superior era de cátedra vitalícia, ocupada pelo catedrático, que era um professor com alto grau de formação, responsável pela administração, pelo controle e pela organização dos trabalhos acadêmicos. A ele cabiam todas as decisões 
referentes ao ensino e, assim, a cátedra era o núcleo da instituição (Olive, 2002). O modelo aqui estabelecido remontava ao modelo português de organização do ensino superior, tendo a Universidade de Coimbra como referência (Martins, 2002).

Só depois de 1850, já no governo de Dom Pedro II, nota-se a expansão gradual das instituições de ensino superior, bem como a criação de centros científicos (Observatório Nacional, Museu Nacional e Comissão Imperial Geológica, todos localizados no Rio de Janeiro). Entretanto, as iniciativas de educação superior permaneceram precárias por longo período, pelos poucos investimentos e pela baixa capacidade de formação, instáveis diante dos interesses imperiais que a comandavam e limitadas pela falta de autonomia e excessiva burocracia (Sampaio, 1991).

Até o fim do século XIX (precisamente até 1878), o ensino superior se manteve público e centrado nas mãos do Império. Ao governo imperial cabia determinar a criação de instituições, indicar sua direção e definir, até mesmo, quem lecionava, seguindo o modelo catedrático das universidades europeias. Com a organização do ensino focada na figura do imperador e submissa às suas ordens, o projeto de criação de universidade — como o universo em pequena escala - não tinha muito alcance, pois colocava em questão o exercício centralizado do poder e controle, além da baixa capacidade de investimentos do governo.

Diante dessa realidade, o que prevaleceu no período imperial foi um modelo de ensino superior para a formação em profissões tradicionais, tais como medicina (com origem na Escola de Cirurgia e Anatomia em Salvador), engenharia (originária da Academia Real Militar), arte (surgida com a Real Academia de Pintura e Escultura), direito e agricultura. Os cursos tinham como foco a formação de profissionais liberais para um mercado de trabalho restrito (Martins, 2002). 
As mudanças no cenário só vieram a acontecer no fim do século XIX, com a abolição da escravidão, em 1888, a destituição do Império e a Proclamação da República (1889). A Constituição de 1889 descentralizou o ensino superior, permitindo a criação de instituições privadas e, assim, ampliou e diversificou o sistema. Como resultado, entre 1889 e 1918, surgiram 56 instituições de ensino superior, em sua maioria, privadas (Olive, 2002; Trindade, 2001).

A criação e o fortalecimento das universidades, ao longo do século XX, têm estreita relação com o avanço da pesquisa, como forma de abrigar a ciência, os cientistas e as humanidades. Emergia entre os docentes, pela via dos movimentos e debates crescentes, a proposta de uma universidade que pudesse ser autônoma para gerir seu funcionamento e seus interesses. Tal proposta foi fortemente influenciada pela Associação Brasileira de Educação ( $\mathrm{ABE}$ ) e pela Academia Brasileira de Ciência ( $\mathrm{ABC}$ ), que propuseram, nas primeiras décadas do século XX, a reformulação do sistema educacional nacional. A ABE teve intensa atividade na década de 1920, diminuindo-a com a Revolução de 1930. Nessa ocasião, o governo de Getúlio Vargas parecia ter assumido as bandeiras de ação defendidas pela associação, entre elas a criação de universidades. A ABC surgiu da transformação da Sociedade Brasileira de Ciências, criada em 1916 e vinculada ao Instituto Franco-Brasileiro de Alta Cultura, entidade criada pelo governo francês. Ambas as instituições propunham a reformulação completa do sistema educacional brasileiro, desde o nível primário - com o projeto Escola Nova — até o nível superior, com o projeto Universidade Brasileira (Sampaio, 1991; Sguissardi, 2011).

O projeto Universidade Brasileira representava o ideal de criação de uma universidade diferente da que se conhecia até então, no Brasil, com a criação de centros de elaboração, ensino e difusão da ciência. Com isso, a universidade devia funcionar como um sistema único, de direção autônoma, constituída de institutos profissionais, institutos técnicos especializados 
e institutos de altos estudos. A nova universidade visava não apenas à formação profissional, mas também à formação e ao desenvolvimento da cultura nacional (Sampaio, 1991; Sguissardi, 2011).

A autonomia representada pela oportunidade de criação e organização de uma universidade sem influências políticas em sua gestão colocava-se como essencial para o modelo de universidade na década de 1930, já no governo de Getúlio Vargas. Em 1931, foi publicado um dos marcos de regulação do ensino superior, o Decreto-Lei n. ${ }^{\circ} 19.851$, que recebeu a denominação de Estatuto das Universidades Brasileiras. A reforma definiu que o ensino superior deveria ser ministrado na universidade e estabelecia uma série de dispositivos para sua organização: finalidades e características fundamentais da universidade, órgãos de administração geral e dos institutos universitários, organização didática, admissão nos cursos, entre outras. Entretanto, as mudanças ainda não garantiam o avanço na proposição do modelo de universidade para a pesquisa, ensino e extensão, além da profissionalização (Sguissardi, 2011).

Ainda nesse período foi criada a Universidade de São Paulo — USP (1934), idealizada pelo intelectual Fernando de Azevedo. A USP nasceu com um espírito inovador, aglutinador da busca do conhecimento e implicada na afirmação do papel da universidade quanto à crítica do saber. Entretanto, Sguissardi (2011) destaca que, desde sua criação, a USP esteve voltada para a formação das elites, e que seus propósitos inovadores à época foram objeto de reação de escolas profissionais, o que resultou no retorno a um padrão de formação profissional.

Nos anos que se seguiram, universidades foram criadas em capitais dos estados, algumas delas com vocação rural, voltadas para as ciências agrícolas (Sampaio, 1991; Sguissardi, 2011). De 1940 a 1960, ocorreu o desenvolvimento das universidades federais, das universidades católicas e das faculdades particulares. Já na década de 1960, sob o regime 
militar, estabeleceram-se as universidades federais em todos os estados e no Distrito Federal. Assim sendo, além do sistema privado, a expansão do ensino superior público é considerada uma herança do governo militar no Brasil.

Apesar de anunciada muito antes, somente em 1968 foi promulgada a primeira reforma universitária brasileira. A reforma baseava-se, em parte, nas proposições de Darcy Ribeiro para a Universidade de Brasília, e contemplava a influência e as ideias do movimento docente e estudantil. A reforma tinha como princípios conceder maior autonomia e, sobretudo, implementar condições democráticas de funcionamento nas universidades, tendo como propostas: (a) a abolição da cátedra e a instituição de departamentos, o que destituía o poder centralizador e permanente que geria o trabalho docente, em particular; (b) a implantação do sistema de institutos básicos, o que também descentralizava o modelo de gestão acadêmica, ao extinguir os institutos centrais de ciências; (c) a organização do currículo em formação básica — e, portanto generalista — e profissionalizante, com o desenvolvimento de saberes específicos e práticos, o que associava o ideal da formação acadêmica, de cunho científico, e da formação profissional, voltada à prática; (d) a flexibilidade curricular na universidade, que permitia o exercício da autonomia e organização do sistema de ensino; (e) o estabelecimento de um sistema de organização, no qual havia espaço para a formação acadêmica e o treinamento profissional, por contemplar estudos generalistas e específicos; (f) a ênfase no papel das universidades para o desenvolvimento da pós-graduação, compreendida como atividade, ao mesmo tempo, de formação de mão de obra e de apoio à pesquisa; (g) a implantação do regime de trabalho de dedicação exclusiva, caracterizado pela contratação de professores que atuavam exclusivamente na universidade, em atividades acadêmicas diversas, o que ampliava o investimento docente nas atividades de ensino, extensão e pesquisa (Olive, 2002; Sampaio, 1991; Sguissardi, 2011). 
No mesmo período, em consequência da reforma universitária, também se ampliaram as instituições privadas, quer nas cidades do interior, quer nas periferias dos grandes centros (Morosini, 2005). Isso se deu pelo interesse do governo na ampliação do acesso da população ao ensino superior. Nos anos seguintes, por influência do governo militar, que também acontecia em outros países da América Latina (Argentina, Chile, México), a repressão esteve presente nas universidades, um período marcado por constantes confrontos entre as IES e as instituições repressivas do Estado, envolvendo tanto os estudantes como os docentes. Nesse período da ditadura, a universidade teve seu funcionamento e organização atacados, o que atrasou a efetivação do modelo criado pelos idealizadores da reforma (Zago, 2011).

Mesmo com percalços, o sistema de ensino superior brasileiro seguiu se ampliando ao longo dos anos 1970. Nas últimas décadas, em especial no século atual, seu crescimento voltou a ser mais acelerado no setor privado. O sistema econômico capitalista e a penetração de ideologias mercantilistas no sistema de ensino superior levam à ampliação da oferta e facilitam o acesso a esse nível de ensino, historicamente elitista e excludente, dadas as condições socioeconômicas da maioria da população. Mas a expansão desafia a manutenção da qualidade da oferta, pois o crescimento acelerado ainda é pouco conhecido — os dados de censos e outras iniciativas do MEC são incipientes em retratar a realidade das instituições privadas de ensino (Severino, 2008; Zago, 2011). Ainda com toda a expansão, Zago (2011) não considera que a educação superior brasileira possa se caracterizar como educação de massa, pois alcança uma parcela pequena da população: 14\% das pessoas entre 18 e 24 anos, conforme dados censitários do Instituto Brasileiro de Geografia e Estatística (IBGE, 2012).

Diante dos desafios e das demandas do novo milênio, a universidade vê-se envolvida em mais um movimento de reforma. Há necessidade de uma política de diversificação que reconfigure o sistema de educação superior, associando princípios de flexibilidade, 
competitividade e avaliação à manutenção da autonomia universitária (Severino, 2008; Sguissardi, 2011). A pressão do modelo societário capitalista neoliberal é para que a educação, em geral, e o ensino superior, em específico, deixem de ser representados como um direito social e se convertam em commodity, isto é, um serviço a ser consumido por um número crescente de usuários. Esse intento tem sido fortemente impulsionado pela crescente ampliação de cursos e vagas em instituições privadas, muitas vezes, sem indicadores de qualidade. A expansão das IES privadas demanda monitoramento e avaliação crítica, que concorram para a qualificação das condições de ensino, pesquisa e extensão, visando ao melhor equilíbrio entre as influências do capital humano e a educação como emancipação humana (Severino, 2008).

\subsection{Educação superior brasileira: Panorama atual}

No Brasil, hoje, os princípios de organização da educação superior são norteados pela Constituição Federal de 1988, em seus artigos 207 e 213. O texto do artigo 207 assegura ao ensino superior autonomia didático-científica, administrativa e de gestão financeira e patrimonial, e determina a obediência ao princípio da indissociabilidade entre ensino, pesquisa e extensão. Por sua vez, o artigo 213 afirma que as atividades de pesquisa e extensão poderão receber apoio do Poder Público.

Os princípios gerais estabelecidos pela Constituição foram regulamentados pela Lei de Diretrizes e Bases da Educação, n. ${ }^{\circ}$ 9.394/1996 (LDBEN), notadamente no capítulo IV, artigos 43 a 57. Essa lei estabelece as finalidades da educação superior (artigo 43), define seus cursos e programas (artigo 44), e prevê que ela será ministrada em instituições públicas ou privadas, com variados graus de abrangência ou especialização (artigo 45). Também regulamenta os 
processos de autorização e reconhecimento de cursos (artigo 46), e define o ano letivo regular (artigo 47), a emissão de diplomas (artigo 48), as regras de transferência entre as IES (artigo 49), a disponibilidade para uso das vagas não preenchidas para estudantes não regulares (artigo 50), as normas de seleção e admissão de estudantes (artigo 51), e as características esperadas das IES em função do perfil formativo pluridisciplinar (artigo 52). A LDBEN trata, ainda, do regime jurídico e de carreira docente do pessoal das universidades públicas (artigo 53), do compromisso da União em assegurar recursos (artigo 55) e da obediência aos princípios de gestão democrática nas instituições públicas (artigo 56) e carga horária mínima semanal do professor (artigo 57).

A organização administrativa e a natureza acadêmica das IES são objeto do Decreto n. ${ }^{\circ}$ 5773/2006, que estabelece a composição do sistema de ensino superior por instituições federais e órgãos federais de educação superior. A educação superior, segundo o Instituto Nacional de Estudos e Pesquisas Educacionais Anísio Teixeira (Inep), abrange os cursos sequenciais (de formação específica ou complementar) e os cursos de graduação (previstos nas modalidades presencial e a distância) e pós-graduação, estes últimos caracterizados como cursos de especialização, mestrado ou doutorado. Inclui, também, os cursos de extensão (de caráter social, sem habilitação ou valor acadêmico) e os cursos tecnológicos.

As IES se organizam em faculdades, centros universitários, universidades, institutos federais e centros de formação tecnológica, de acordo com padrões de funcionamento e qualidade estabelecidos pelo MEC. As instituições públicas estão divididas em federais, estaduais e municipais. Já as instituições privadas se dividem em sem fins lucrativos (comunitárias, filantrópicas) e com fins lucrativos (MEC, 2011; Oliveira, 2011).

O Censo da Educação Superior é produzido pelo Inep, órgão responsável por promover estudos e avaliações da educação brasileira, e também por gerar informações sobre os cursos 
de graduação no país. Segundo os dados do censo de 2012, havia 2.416 IES no Brasil, sendo 87,4\% privadas e 12,6 \% públicas, divididas em 193 universidades, 139 centros universitários, 2.044 faculdades e 40 institutos federais e centros de formação tecnológica. Entre essas informações, faz-se importante destacar o peso representado pelas IES privadas (88\%), em termos quantitativos, na educação brasileira.

No Brasil, as iniciativas estatais de ampliar e qualificar as condições de acesso ao ensino superior têm sido organizadas por ações provenientes de políticas públicas. Como exemplos das ações, destacam-se o Plano Nacional de Educação (PNE), o Plano de Desenvolvimento da Educação (PDE), o Plano de Reestruturação e Expansão das Universidades Federais Brasileiras (Reuni) e o Programa Universidade para Todos (ProUni).

O PNE teve a finalidade de elevar o nível de escolaridade da população, melhorar a qualidade do ensino em todos os níveis, reduzir as desigualdades sociais e regionais de acesso e permanência na educação e democratizar a gestão escolar. As metas previstas no plano devem ter a duração de dez anos. O primeiro plano foi aprovado e regulamentado em 2001, pela Lei n. ${ }^{\circ} 10.172$ (Brasil, 2001). Pelo caráter decenal, um novo plano já deveria estar em vigor desde 2012, entretanto, a nova proposta para o PNE foi promulgada recentemente, por meio da Lei . $^{\circ} 10.035 / 2014$.

Na versão hoje vigente, de 2014, o PNE estabelece 20 metas para a elevação da qualidade da educação, trazendo como novidades: garantir vagas para todas as crianças de $4 \mathrm{e}$ 5 anos até 2016; ampliar o acesso da população em geral ao ensino médio; universalizar o atendimento aos estudantes de 4 a 17 anos com deficiência, transtornos globais do desenvolvimento e altas habilidades ou superdotação; ampliar a educação em tempo integral para 50\% das escolas; elevar a escolaridade média da população de 18 a 29 anos; elevar a taxa 
de matrícula na educação superior para a população de 18 a 24 anos; elevar as matrículas na pós-graduação; e ampliar o investimento público em educação.

O PDE, lançado em 2007, propôs um conjunto de medidas com a finalidade de melhorar o desempenho das instituições de ensino em todos os níveis. A educação superior ganhou metas voltadas à ampliação do acesso e à articulação entre programas de financiamento. As estratégias desenvolvidas com esse fim foram o Reuni e o ProUni. O Reuni teve o objetivo de melhorar as condições de acesso e permanência dos jovens na graduação, reduzir a evasão e garantir o aumento substancial das vagas no ensino superior público, em especial nas áreas de interesse das licenciaturas, ensino da saúde e novos campos de conhecimento tecnológico. Como contrapartida, o programa garantia recursos para o incremento das estruturas físicas e dos recursos humanos das universidades públicas. Já o ProUni foi instituído pela Lei n. ${ }^{\circ} 11.096 / 2005$, com o objetivo de conceder bolsas de estudo integrais e parciais em cursos de graduação e sequenciais de formação específica.

Há também o Fundo de Financiamento ao Estudante do Ensino Superior (FIES) como forma de ampliar o acesso ao ensino superior privado. O FIES tem representado oportunidade para os estudantes das camadas mais pobres da população acessarem o ensino superior; por outro lado, é um forte incremento às instituições de ensino privadas, que têm compreendido a educação como empreendimento financeiro. O sistema também é alvo constante de discussão sobre a qualidade da educação praticada nas instituições.

De uma forma ou outra, essas ações têm ampliado o acesso ao ensino superior, e por isso vão ao encontro dos ideais propostos pela Conferência Mundial sobre Educação Superior, ocorrida em 2009 em Paris. Embora passíveis de críticas e reformulações, elas têm possibilitado que muitas pessoas realizem um curso de nível superior. 
Entretanto, não podemos desconsiderar o impacto do neoliberalismo na área educacional, especificamente no ensino superior, que resultou na ampla abertura para a exploração mercadológica do setor e vem contribuindo para converter a educação em mercadoria. A educação superior passou a constituir um segmento promissor para o investimento de capital. Infelizmente, o acelerado crescimento não foi acompanhado da preocupação com os objetivos da educação superior (Oliveira, Paschoalino \& Rocha, 2011).

De forma geral, a experiência do ensino superior deveria se efetivar como mediação da cidadania e da democracia (Severino, 2008), oportunidade de formação para a pesquisa e a profissionalização. Mas o que vivenciamos é uma realidade distante desses ideais, marcada por modelos empresariais e mercantis de educação, o que acaba por comprometer sua qualidade (Freitas, 2011). Desse modo, os desafios que se colocam, atualmente, à educação superior brasileira concentram-se em potencializar o alcance, conjugando a ampliação do acesso e a qualidade da oferta da formação em nível superior, na sua relação com o mundo do trabalho e com a cidadania. Caminhando nesse sentido, a Conferência Mundial da Unesco sobre a Educação Superior, realizada em 2009, trouxe à tona a importância da promoção da participação dos países e o compromisso dos governos com a conclusão bem-sucedida dos cursos. Destacou também a responsabilidade de todos, em especial os governantes, com o bem-estar dos estudantes, por meio de suporte financeiro e educacional adequados, prioritariamente os estudantes mais pobres e de comunidades em situação de vulnerabilidade e exclusão (Unesco, 2009).

Como já afirmado, a discussão se concentra em conhecer a realidade das universidades e dos estudantes, bem como as condições de permanência e a qualidade do ensino ofertado. Em relação aos estudantes com deficiência, torna-se fundamental a aproximação com a realidade vivenciada no ensino superior, a fim de compreender como o contexto e os desafios 
inerentes a esse nível de ensino são percebidos e enfrentados pelos estudantes. Esse é o tema da seção que vem a seguir.

\subsection{A inclusão no ensino superior: Desafios e perspectivas}

Ao traçar o panorama da educação superior inclusiva, é importante destacar os dados sobre deficiências na população brasileira. Segundo o Censo (SNPD, 2013), 23,9\% da população do Brasil, cerca de 45.600 .000 pessoas, têm algum tipo de deficiência (visual, auditiva, motora ou intelectual). Desse total, 25.800 .000 (26,5\%) são mulheres e 19.800 .000 $(21,2 \%)$ são homens. Quando se comparam os dados sobre nível de instrução das pessoas com e das pessoas sem deficiência, temos o seguinte gráfico:

Gráfico 1 - Distribuição da população por nível de escolarização

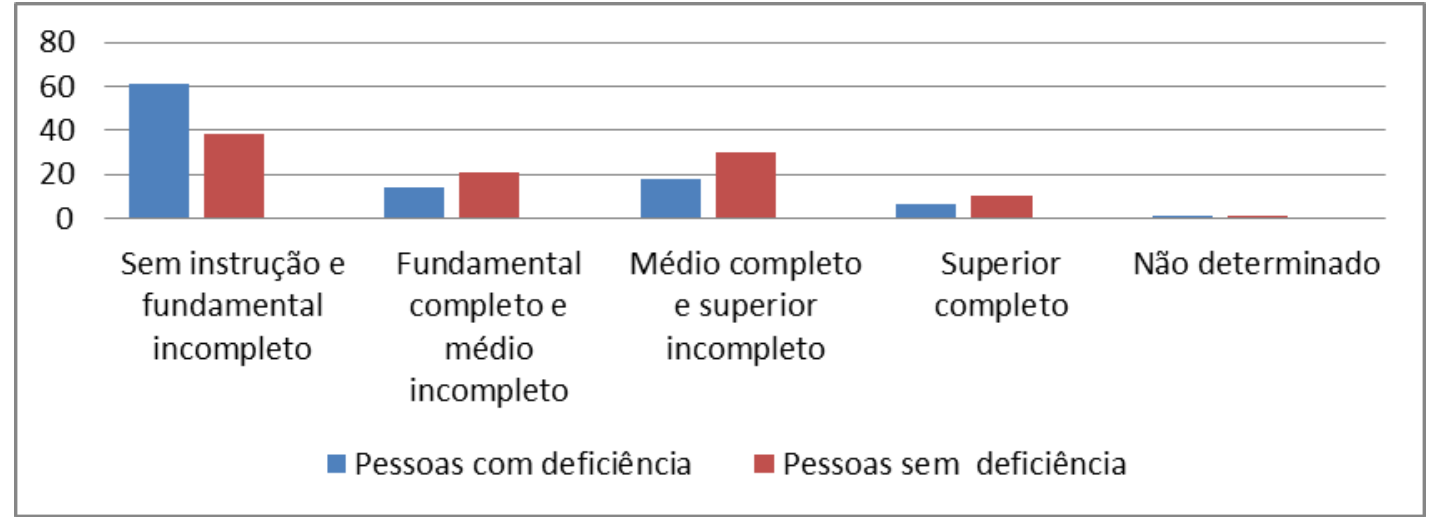

Fonte: SNPD, 2013. 
Nota-se que há grande desvantagem para as pessoas com deficiência quando se analisam as três primeiras categorias. Em relação ao ensino superior, os contrastes não são tão marcantes, uma evidência de que, nesse nível, há outros fatores socioeconômicos e políticos que constituem barreiras ao acesso da população em geral. O cenário da escolarização das pessoas com deficiência reflete, conforme já afirmado, um histórico de condições adversas de desenvolvimento, falta de oportunidades e condições inadequadas de aproveitamento escolar.

Chegar à universidade e permanecer até a conclusão do ensino superior é um desafio para todos os estudantes (Coulon, 2008; Figueiredo et al., 2011; Ressurreição, 2013), em especial para os que têm deficiência (Marcondes \& Caiado, 2013). A experiência universitária é um importante marcador de trajetória de desenvolvimento pessoal e social, tanto pelas oportunidades de formação acadêmica quanto pelas relações sociais estabelecidas, que se espera sejam pautadas em posturas éticas e humanizadas (Marinho-Araújo, 2009, 2011). Recai sobre as universidades a expectativa social de que se diminuam as diferenças impostas pelos padrões potencialmente desiguais estabelecidos, historicamente, na sociedade brasileira.

O ensino superior tem como característica ser um tempo e espaço de interações e transições na vida dos estudantes, demarcado por regras, valores e crenças próprias. O sucesso nesse tempo exige do estudante o desenvolvimento de habilidades pessoais e sociais (Del Prette \& Del Prette, 1998). Acessar o ensino superior abre possibilidades para que o estudante se aproprie do espaço simbólico da universidade; reconheça seu ofício em meio a ele (Coulon, 2008); e se sinta incluído no sistema de valores que perpassam esse nível de ensino. Da mesma forma, a experiência universitária tem um papel importante no desenvolvimento pessoal, ao conferir novas visões de realidade, que possibilitem (re)posicionamentos identitários e recolocações espaçotemporais, transformações essas que ocorrem de forma dinâmica e negociada (Ressurreição, 2013). O ensino superior também se destaca no 
desenvolvimento profissional dos sujeitos como oportunidade para a inserção no mundo do trabalho. Considerando as atuais relações mercantis, em que a competição e as exigências são cada vez maiores, a formação universitária pode representar um diferencial na colocação no mercado de trabalho.

Além de promotor de desenvolvimento, o ensino superior representa um período importante na trajetória de vida dos indivíduos — segundo Coulon (2008), a transição do estatuto de aluno ao de estudante. A experiência pode favorecer o desenvolvimento do senso crítico e levar à participação social ativa dos estudantes. Entretanto, por sua característica de um ensino voltado a adultos e historicamente comprometido com a profissionalização, várias rupturas simultâneas ocorrem e exigem do indivíduo adequação e afiliação ao novo contexto, o que pode constituir um processo mais complexo quando se consideram os estudantes com necessidades especiais.

No Brasil, há ações afirmativas voltadas à inclusão de minorias nos espaços de ensino superior, a exemplo do sistema de cotas. A Lei n. ${ }^{\circ}$ 12.711/2012 reserva vagas para estudantes provenientes de escolas públicas, considerando quesitos de raça e cor. Também há a iniciativa de universidades que reservam cotas para estudantes com deficiência e indígenas, bem como programas voltados à ampliação do acesso ao ensino superior. Exemplos de universidades que instituíram o sistema de cotas antes que esta se tornasse uma política nacional são a Universidade de Brasília e a Universidade Federal da Bahia. Outras ações com forte impacto na redução das desigualdades no acesso ao ensino superior são o Reuni, o ProUni e, no contexto da deficiência, o Programa Viver sem Limites e o Programa Incluir. ${ }^{5}$

\footnotetext{
${ }^{5}$ Mais informações sobre os referidos programas são acessadas no portal do MEC, em: www.mec.gov.br.
} 
Deve-se destacar, ainda, iniciativas provenientes de movimentos sociais, como a Carta do Rio: Celebrar, Consolidar e Ampliar as Políticas de Ação Afirmativa. A carta foi elaborada por iniciativa de pesquisadores, gestores e ativistas, e assinada em seminário comemorativo dos dez anos de ações afirmativas daquele estado, em 2012. Nela é salientada a importância das políticas afirmativas que ampliam o acesso e a permanência de jovens de menor renda, negros e indígenas na educação superior.

As dificuldades e barreiras à permanência de grupos menos favorecidos são comuns no espaço universitário, e por isso justificam-se as iniciativas do Estado e dos movimentos sociais. De um lado, merece destaque a importância de ações já consolidadas no propósito inclusivo, mas, de outro, não se deve desconsiderar a complexidade e as demandas próprias desse contexto. A implementação de ações inclusivas para fomentar a inserção de jovens com deficiência no ensino superior é necessária, a fim de melhorar as condições de permanência e aproveitamento da experiência acadêmica.

Ainda que algumas ações afirmativas no ensino superior tenham avançado, a exemplo das iniciativas aqui referidas, ainda não se mostram capazes de responder à questão dos estudantes com deficiência. Essa é uma parcela de estudantes que ainda sofre invisibilidade, o que dificulta a superação de situações de estigmatização (Goffman, 1988), como a discriminação, a ausência de perspectivas e as barreiras que vão se interpondo ao desenvolvimento de habilidades e funcionamento ativo do indivíduo (Dias, 2004, 2014; Mantoan, 2008). Essa constitui uma preocupação de fundo desta tese, conforme indicarão seus objetivos e desenho metodológico, apresentados adiante. 


\subsection{Educação inclusiva e ensino superior em Portugal}

Um levantamento da legislação sobre a inclusão escolar de pessoas com deficiência permite verificar que não há documentos específicos que orientem as ações e os processos de inclusão no ensino superior português (Antunes \& Faria, 2013; Santos, 2013). Portanto, os documentos capazes de amparar a definição de ações inclusivas no ensino superior são os mesmos que se dedicam às práticas nos demais níveis de ensino. São eles: a Constituição da República Portuguesa; a Lei de Bases do Sistema Educativo (Lei n. ${ }^{\circ}$ 46/1986), alterada pelas Leis n. ${ }^{o} 115 / 1997$ e n. ${ }^{\circ}$ 49/2005; o Decreto-Lei n. ${ }^{\circ}$ 3/2008; a Lei de Bases para o Financiamento do Ensino Superior (Lei n. ${ }^{\circ}$ 37/2003); e a Lei n. ${ }^{\circ}$ 46/2006.

A Constituição da República Portuguesa, aprovada em 1971, em seus artigos 71, 73 e 74, aborda a previsão de direitos e deveres dessa parcela da população. A Lei de Bases do Sistema Educativo (Lei n. ${ }^{\text {4 } 46 / 1986), ~ a l t e r a d a ~ p e l a s ~ L e i s ~ n . ~}{ }^{\circ}$ 115/97 e n. ${ }^{\circ}$ 49/2005, também se

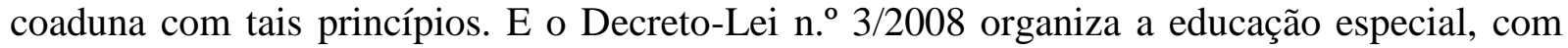
orientações mais voltadas para a educação básica e o ensino secundário, mas destaca a importância da concepção e gestão dos espaços a fim de contribuir para o sucesso educativo e

escolar dos alunos. Já a Lei de Bases para o Financiamento do Ensino Superior (Lei

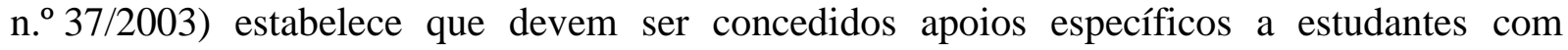
deficiência. Por fim, a Lei n. ${ }^{\circ}$ 46/2006 tem por finalidade prevenir e coibir a discriminação, direta ou indireta, em decorrência da deficiência.

Como expomos, a legislação específica existente é direcionada à educação pré-escolar, ao ensino básico e secundário, sem abordagem direta do ensino superior. E, de forma geral, orienta a criação de apoios pedagógicos adequados às necessidades individuais dos estudantes com deficiência na trajetória escolar. Deve-se destacar, por outro lado, a reserva, desde 1985, 
de $2 \%$ das vagas do ensino superior a candidatos com deficiência física ou sensorial, previsto no regulamento do Concurso Nacional de Acesso ao Ensino Superior, definido pelo Ministério da Educação de Portugal (Pires, 2007; Santos, 2013).

Com a inclusão, é crescente a demanda por acesso ao ensino superior por parte dos estudantes com deficiência. Diante dessa realidade, as IESs têm sido convocadas a responder às demandas dos estudantes. Surgiram assim, em algumas instituições, políticas internas, regimentos, programas e ações voltadas à finalidade de promover a inclusão. Essas ações foram influenciadas por movimentos e iniciativas anteriores, algumas das quais tiveram origem no debate internacional mobilizado pela União Europeia. Elas contribuíram para ampliar a discussão e a visibilidade sobre o tema, promovendo reflexões que têm resultado em proposições e orientações mais claras (Antunes \& Faria, 2013; Pires, 2007).

As diretivas comunitárias da União Europeia ${ }^{6}$ sobre igualdade de oportunidades das pessoas com deficiência nas áreas de combate à discriminação, emprego e atividade profissional, acesso a serviços de apoio e cuidados, de acordo com Pires (2007), tiveram impacto positivo sobre o acesso e a permanência de estudantes portugueses no ensino superior. Outra iniciativa foi a adoção do Plano de Ação Europeu para a Deficiência (2004-2010), que tem como princípio o fortalecimento dos valores de não discriminação e integração das pessoas com deficiência ou incapacidade na União Europeia. Somaram-se, ainda, as opções do Plano 2005-2009, aprovadas em Conselho de Ministros, em 2005, com a previsão de ações e medidas para a melhoria das condições de acesso e frequência ao ensino superior para estudantes com deficiência (Pires, 2007).

\footnotetext{
${ }^{6}$ As diretivas em questão compõem o Manual sobre a Legislação Europeia Antidiscriminação, organizado pela Agência dos Direitos Fundamentais da União Europeia. Datado de 2010, ele reúne várias orientações, ações e aplicação da legislação antidiscriminação na União Europeia.
} 
Uma iniciativa de apoio aos sistemas inclusivos nas universidades foi a criação do Grupo de Trabalho para o Apoio a Estudantes com Deficiências no Ensino Superior (GTAEDES). O grupo tem o objetivo de partilhar experiências e definir orientações para políticas e normas para os serviços de suporte a estudantes com deficiência. É composto por instituições de educação pública e por representantes da Direção-Geral do Ensino Superior (DGES), da Agência para a Sociedade do Conhecimento (Umic) e do Instituto Nacional para a Reabilitação. Entre as iniciativas, também têm se destacado ações como a formação contínua de professores, a adaptação de currículos, a produção de recursos pedagógicos e a criação de serviços e programas de apoio aos alunos (Antunes \& Faria, 2013). Deve-se salientar que, em virtude da ausência de um marco legal regulador das medidas de apoio, as iniciativas ainda são locais e particulares de cada instituição.

Embora o ensino superior português caminhe em direção a alternativas que respondam à questão da inclusão, muitas vezes, as propostas limitam-se à replicação de medidas educativas já utilizadas no ensino básico e secundário (Abreu, 2013; Fernandes \& Almeida, 2007; Faria, 2012). Destacamos, no processo de mudança e adaptação das instituições, o papel de cada universidade. É da sua iniciativa e responsabilidade a criação e a busca de qualidade para o funcionamento dos serviços de apoio e mediação dos processos inclusivos como forma de promover a plena inserção acadêmica, a aprendizagem e o desenvolvimento dos estudantes com deficiência.

Enfim, diante da responsabilidade de incluir os estudantes com NEE, as universidades de Portugal têm se confrontado com um desafio importante: de um lado, como vimos, o tema é recente e ainda não conta com legislação específica, estudos e experiências capazes de orientar as ações; de outro, a procura é crescente e impulsiona de forma urgente a tomada de decisão (Fernandes, Almeida \& Mourão, 2007; Antunes \& Faria, 2013). No acesso ao ensino superior, 
esses estudantes precisam de respostas cada vez mais eficazes, que contribuam para mais qualificadas condições de permanência e aproveitamento (Antunes \& Faria, 2013).

É crescente o reconhecimento de que o espaço das instituições de ensino superior configura-se em destacado marcador social, acadêmico e profissional na vida dos jovens e adultos que o integram. Também se reconhece que todos os estudantes precisam encontrar experiências sociais e acadêmicas ampliadas, relações mais éticas e igualitárias e, assim, oportunidades de desenvolvimento global.

E assim, tendo como contexto o ensino superior, acessado por indivíduos jovens em transição para a idade adulta ou já adultos, discutimos, no capítulo a seguir, os processos de desenvolvimento e algumas de suas especificidades na perspectiva da psicologia cultural. 


\section{Psicologia do Desenvolvimento humano: Perspectivas E INTERPRETAÇÕES}

Este último capítulo teórico adiciona ao estudo as contribuições da psicologia do desenvolvimento humano, em matriz cultural. Relaciona as perspectivas dialógica e semióticocultural e, à luz delas, propõe uma interpretação para o desenvolvimento adulto. Seguindo essa direção, expõe um referencial analítico para a compreensão das trajetórias de desenvolvimento dos estudantes participantes da pesquisa. E, com isso, embasa o entendimento de algumas especificidades do desenvolvimento adulto, quando se trata de sujeitos com deficiência inseridos no ensino superior.

\subsection{Perspectiva semiótico-cultural e dialógica}

Compreendemos o desenvolvimento humano com base nas proposições da psicologia cultural e, mais especificamente, das perspectivas semiótico-cultural e dialógica. A definição que adotamos descreve o desenvolvimento como processo que se dá ao longo da vida, de forma assíncrona, descontínua e correlacionada, num tempo irreversível (Carvalho, 1996; Valsiner, 2002; Zittoun, 2009). Adotamos uma noção relacional de desenvolvimento. Se o indivíduo se constitui em meio às relações, sendo considerado sempre em perspectiva a outro sujeito, os significados também são considerados em relação a outros, em processos complexos de significação. Entendemos que duas abordagens possuem aproximações e trabalham com a visão relacional de desenvolvimento: a semiótico-cultural e a dialógica. 
Na abordagem semiótico-cultural, o foco está prioritariamente na relação sujeitocultura, na construção de significados, que são, por natureza, significados culturais. Na abordagem dialógica, o foco desloca-se para a relação sujeito-outro, num dado contexto. A relação entre sujeito e cultura se dá por meio da interação com os outros, assim como a relação entre sujeito e outro se dá em cenários culturais (Branco, 2006). Por isso, nossa proposição é relacionar sujeito, outro e cultura como elementos da mesma concepção de desenvolvimento. Ao juntarmos nessa concepção a abordagem semiótico-cultural e a abordagem dialógica, propomos uma visão triádica para a compreensão dos fenômenos.

O desenvolvimento é construído de forma interativa e relacional, considerando simultaneamente a unicidade e pluralidade dos fenômenos pessoais e sociais, numa visão sistêmica. Compreender os processos de desenvolvimento é assumir a multicausalidade e complexidade dos processos, o que sugere a superação de modelos normativos, que tendem a desconsiderar a dinamicidade e complexidade dos processos de desenvolvimento humano. A abordagem do desenvolvimento humano deve incluir em uma mesma unidade de análise os processos biológicos, psíquicos, sociais, afetivos e cognitivos que ocorrem ao longo da vida (Zittoun, 2007). A dinâmica do desenvolvimento provém das relações entre o indivíduo e o contexto. De acordo com essa perspectiva, o indivíduo é considerado como ser ativo, que tem agencialidade e é coautor dos próprios processos de desenvolvimento.

O desenvolvimento pode ser considerado como processo semiótico, originariamente interpessoal e posteriormente intrapsicológico. Com o avanço do desenvolvimento ontogenético, a dinamicidade se torna tão aguda que não é mais possível fazer essa separação, sendo os fenômenos complexos do desenvolvimento adulto compreendidos com tendo sempre dimensões intra e interpsicológicas. As interações e transações sociais são o palco de negociação de significados, possibilitando às pessoas a tomada de posicionamentos e a 
construção de novas significações mediadas pela alteridade. A dinamicidade que permite a construção de significações se dá, segundo Valsiner (2012), porque os indivíduos estão em constante reelaboração de seus mundos intrapsicológicos, pela troca de materiais perceptivos e semióticos com o ambiente. A reconstrução, constitui um processo de internalização, resultado de análises de materiais semióticos que existem externamente e de sua síntese, sob novas formas intrapsicológicas (Valsiner, 2012). E, num cenário de transformações sucessivas, permanentes, sistêmicas, multilineares, o desenvolvimento é também dinâmico e interativo (Kelman, 2010; Valsiner, 2002). Assim, no movimento de permanentes transformações que desencadeiam transições e reorientações, o fluxo das interações entre as características da pessoa e os contextos em que ela se insere promove o desenvolvimento (Kelman, 2010; Valsiner, 2012; Zitttoun, 2009).

É importante perceber que o processo de desenvolvimento se dá pela presença de marcadores bem definidos: interação, influência, descontinuidade, mudança, todos eles materializados em ações que estão em negociação na vida do indivíduo cotidianamente (Valsiner, 2012; Zittoun, 2009). Dias e Lopes de Oliveira (2013) enfatizam essa dinamicidade, ressaltando que o sentido do desenvolvimento não se centra no progresso, mas sim no movimento contínuo em que os fenômenos se materializam nas condições de vida.

A abordagem semiótico-cultural tem como objeto de estudo a sociogênese, de acordo com a qual os fenômenos se dão nas relações entre as pessoas em contextos estruturados pela cultura. $\mathrm{O}$ enquadramento cultural dos contextos significa que eles se organizam para direcionar as trajetórias dos sujeitos, em processos de canalização cultural (Valsiner, 2007). Nesse sentido, a psicologia cultural é definida como o estudo e a interpretação de fenômenos de desenvolvimento relacionados à construção de signos por indivíduos em interação, 
interação esta mediada pelos recursos de um determinado contexto e pelas experiências do passado transpostas para o tempo presente (Valsiner, 2012).

A psicologia semiótico-cultural defende uma compreensão relativista, contextual e integradora do desenvolvimento humano, que enfatiza o valor da cultura e dos contextos sociais no desenvolvimento. A perspectiva semiótico-cultural é uma abordagem teóricometodológica e epistemológica que caracteriza o desenvolvimento humano como sistema aberto; que se dá mediante a interação com o outro, por meio de signos e ferramentas culturais (Valsiner, 2002; Vygotsky, 1995).

A construção de conhecimento na psicologia semiótico-cultural considera o indivíduo em sua participação nos grupos sociais. A análise toma como foco o indivíduo no contexto social. Assim, de forma sistêmica, busca compor um modelo do comportamento cultural, passível de generalização, sem, entretanto, deixar de considerar as singularidades individuais e as diferenças intersubjetivas. A busca se orienta para a descoberta de princípios fundamentais básicos (Valsiner, 2012).

Nessa perspectiva, a noção de cultura emerge como parte do sistema de funções psicológicas intra e interpessoais. Tratada assim, a cultura integra o sistema psicológico individual, relaciona-se à mediação semiótica e concretiza-se nos processos vividos pela pessoa em sua experiência no mundo (Valsiner, 2012). Por isso é necessário considerar o papel dos signos. Essa via semiótica alinha-se com a compreensão históricocultural de desenvolvimento, formulada principalmente por Vygotsky. Nessa compreensão, o desenvolvimento resulta das interações ao longo da vida, e se dão como parte de um sistema cultural, no qual todos estão inseridos.

Como referencial epistemológico, a perspectiva semiótico-cultural propõe uma visão de sujeito que, em interação com o outro e com a cultura - concebida como repertório de 
signos —, amplia sua participação social e constrói possibilidades de desenvolvimento num tempo irreversível. Nessa abordagem, o desenvolvimento não é considerado um processo linear e está baseado nas interações entre os indivíduos e o ambiente num dado tempo e contexto. Os principais autores que embasaram a construção da matriz foram William James, Charles Peirce, George Mead, Lev Vygotsky e Mikhail Bakhtin. E os autores contemporâneos de maior destaque são Ernest Boesch e Jaan Valsiner.

As interações sociais são cenários dinâmicos de negociação semiótica e, dessa forma, podem afetar e transformar os indivíduos, promovendo o seu desenvolvimento. Em outras palavras, a construção de significados é a base dos processos semióticos, afetivos e sociais nos contextos culturais (Branco, Pessina, Flores \& Salomão, 2004). Os seres humanos são culturais pela criação e pelo uso de signos (Valsiner, 2012). É preciso considerar a cultura como sistema coletivo e individual, que participa da constituição do sujeito psicológico (Kelman, 2010). Ela é um sistema de crenças e valores, que compõem um sistema simbólico mais amplo, permeado por trocas entre os indivíduos, que podem ser internalizadas ativamente, articulando seus valores e significados pessoais. A cultura se liga a processos humanos, nos quais vamos nos inserindo ao longo da vida (Valsiner, 2007).

De acordo com Valsiner (2012), a cultura é parte da organização sistêmica do indivíduo. Ao mesmo tempo, é inerente às funções psicológicas humanas, e decorrente das experiências relacionais dos indivíduos em sistemas culturalmente estruturados de atividades humanas. As experiências relacionais, semióticas em sua gênese, constituem-se tendo por território a linguagem, a cognição e também os afetos. A interação entre esses fatores é objeto da teoria dos campos afetivos (Valsiner, 2007).

Valsiner (2007) refere-se aos campos afetivo-semióticos como sistemas de signos sociais pregnantes, que vão sendo internalizados ao longo da história de cada um como 
membro de sua cultura. Esses signos orientam os sujeitos no delineamento de posicionamentos psicológicos perante a construção de valores, a orientação para expectativas e a consecução de objetivos. De acordo com o autor, os campos afetivos podem ser pensados em uma organização sistêmica, dividida em níveis ou dimensões, que se referem aos significados construídos nos níveis pré-verbal, verbal e pós-verbal. O nível 1 dos campos afetivos é préverbal; nele, os significados têm como base o corpo fisiológico, a mera atividade proprioceptiva. Os níveis 2 e 3 são verbais, definidos em torno de significados mediados pela língua. O nível 2 é aquele no qual emergem das emoções experimentadas as primeiras categorizações, ao passo que o terceiro nível é o que engloba os signos sociais, mediadores de processos de internalização. O nível 4, denominado pós-verbal, é constituído por signos hipergeneralizados - signos que antes eram mediadores (nível 3) e que, por sua intensa penetração nos sistemas semióticos, historicamente consolidados na cultura, convertem-se em signos reguladores, matriz do sistema de valores internalizados pela pessoa.

De acordo com essa matriz, os valores referem-se a crenças profundamente enraizadas, carregadas de afeto e com papel destacado nos processos de construção de significados. Entendidos na perspectiva semiótica, os valores são constituídos na cultura e reproduzidos intersubjetivamente, quando internalizados pelos sujeitos, que deixam de perceber que sua conduta, em determinadas esferas de atividade humana, é regulada por eles. Os valores, segundo Valsiner (2007, 2010, 2012), são signos hipergeneralizados que orientam ações, interações e diálogos.

Esta tese se apoia também no enfoque dialógico. Nesse âmbito, uma contribuição teórica central se pauta na obra de Bakhtin e do Círculo de Estudos Literários, liderado por ele. De acordo com o movimento liderado pelo círculo de Bakhtin, "diálogo" e "dialogismo" são conceitos que não se confundem. Diálogo representa um fato textual, o qual está inserido num 
processo discursivo mais amplo do que aquilo a que se denomina dialogismo (Bakhtin, 1997). Este último, por sua natureza, é baseado na inter-relação com o outro como condição necessária para dialogar, seja este outro físico ou não, em um entrelaçamento que produz sentido. Bakhtin (1997) assumiu o dialogismo, de forma ampla, como cenário para a colisão de ideias e heterogenia de significados em ação.

Segundo Bakhtin (1997), todos os indivíduos vivem no mundo das palavras dos outros. Os humanos fazem o mundo de acordo com os outros, e toda a existência do eu é orientada de acordo com a linguagem do outro e com o mundo do outro. Cada palavra, enunciado ou texto é um elo em uma cadeia discursiva iniciada no passado e conectada com o futuro. Desse modo, a existência assume a dupla função de "responder" a algo ou alguém do passado e endereçar uma "pergunta" a outro.

Da parte de Vygotsky (1989), o fundamento dialógico da vida mental também se apresenta, ancorado em vários conceitos e proposições espalhados em sua obra, os quais traduzem a ideia de que a pessoa é, ao mesmo tempo, indivíduo e coletividade, visto que se constitui por meio da internalização construtiva de processos sócio-histórico-culturais. Um dos pontos relevantes de sua obra em que tal fundamento está presente situa-se na descrição da formação da vida psíquica, a que denomina a "lei da dupla formação": tudo aquilo que hoje é parte da vida psíquica foi antes formado na vida social.

Tomando o dialogismo como princípio, nossos pensamentos nascem e se formam de enunciados dos outros, ou seja, em interação e negociação com o pensamento alheio. É o pensamento e o enunciado do outro, que reflete nas formas de expressão verbal de nosso pensamento (Bakhtin, 1997). Um interesse do dialogismo é compreender a interação entre os enunciados do outro e como eles se refletem em nossos enunciados. 
Com isso, a epistemologia dialógica é caracterizada pela multivocalidade, aqui entendida como a presença de múltiplas vozes que comparecem no diálogo inter e intrapessoal e que se apresentam na constituição subjetiva do self. Outra característica é a reflexividade, mecanismo pelo qual o indivíduo, na tomada de consciência de si, adota como recursos o seu discurso e o discurso dos outros, com a finalidade de compor significados. Para isso, aciona recursos pessoais e sociais que o auxiliam a responder a si e à alteridade. Entendemos que a reflexividade participa da construção dos significados que constituem o sujeito (Bakhtin, 1997).

As análises literárias do grupo de Bakhtin projetaram-se em torno da interação dialógica entre autor, personagem e leitor na constituição do significado da obra, e têm sido fonte de inspiração para a compreensão da relação entre sujeito/outro mediada pelo diálogo (Ponzio, 2012; Salgado \& Gonçalves, 2007). Bakhtin (1997) ressalta que as ciências sociais e humanas se formaram em torno da necessidade de entender como se transmitem e interpretam os discursos dos outros — uma necessidade, em si mesma, dialógica.

Em outras palavras, um significado ou conceito se define na relação com outro significado. Linnel (2009) igualmente discute o princípio do dialogismo e reitera que ele pode ser compreendido como um instrumento metateórico, epistemológico, pelo qual conhecemos o mundo e, no contexto das participações e interações concretas, atribuímos significados a ele. Nesse sentido, a participação dialógica se efetiva nos diferentes espaços institucionais, como família, escola ou trabalho e, ainda, nos demais grupos com os quais se interage.

O dialogismo é característica intrínseca ao fenômeno da vida, que é considerada dual, polissêmica, um contínuo exercício de diálogo (Fávero, 2005; Paula \& Stafuzza, 2008). A abordagem dialógica contribui e amplia essa noção de dualidade ao enfatizar a separação entre o coletivo e o individual, o subjetivo e o social, que se dá por meio do diálogo. Nessa hipótese, 
o próprio funcionamento individual pode ser caracterizado como dialógico, ao considerarmos que o indivíduo dialoga consigo e constrói significados encadeados em outros significados, seja por aproximação de sentido, seja por oposição.

Os fundamentos do dialogismo são objeto de reflexão de teóricos contemporâneos que seguiram a trilha do pensamento russo. Para Souza e Gomes (2009), o dialogismo pode ser representado como a experiência vivida na linguagem, ou seja, como o processo de comunicar a consciência. Esse processo é como uma moeda: tem uma face interna ou reflexiva, caracterizada pelos processos em que a consciência volta-se sobre si mesma; e outra externa, momento em que a consciência se dirige a outras consciências, promovendo a interação dialógica.

Sobral (2008) renova a ênfase dada por Bakhtin à interação dialógica como "uma arena de vozes", espaço muitas vezes de tensão no qual, por meio do diálogo, pode ocorrer o confronto de diferenças, de ideias. Dada a característica relacional da espécie humana, mesmo diante de importantes diferenças ideológicas e (in)compreensões, o diálogo e a experiência de interação são bases para a promoção de desenvolvimento.

Cada pessoa está sempre na fronteira entre o seu mundo interno e a realidade externa. Todas as atividades simbólicas dos seres humanos se justificam no diálogo entre as mentes, na contínua expressão e negociação de significados. Eis aí a relação entre o dialogismo e a perspectiva semiótico-cultural. Os processos de significação semióticos e culturais se constroem e reconstroem pelo diálogo. Assim, a linguagem assume papel destacado no desenvolvimento por configurar um dos principais contextos para as interações humanas, possibilitando que a mediação de significados se concretize numa dada cultura. 
As perspectivas semiótico-cultural e dialógica, por suas características, aproximam-se e compõem uma visão mais complexa do desenvolvimento humano, a qual julgamos apropriada à presente pesquisa.

\subsection{A universidade como contexto de desenvolvimento humano}

Zittoun (2007, 2009) investiga o desenvolvimento humano como fenômeno dinâmico e contínuo, que deve ser tomado como um sistema não linear e em constante transformação no curso de vida. De acordo com a autora, o desenvolvimento dá-se pelo estabelecimento de regularidades e continuidades, mas também por interrupções, reorientações e mudança, o que envolve a integração dinâmica de processos biológicos, psicológicos, interpessoais e sociais.

Em concepções teóricas mais tradicionais, a fase adulta é caracterizada tendo como referências transições normativas, tais como o casamento, a paternidade e a obtenção de um emprego. Entretanto, a partir da década de 1970, houve uma alteração das concepções que associavam a transição para a vida adulta a marcadores definidos em torno dessas obrigações sociais. Estas deram lugar a novas concepções, mais focadas na valorização da autonomia do indivíduo (Arnett, 2000), que consideravam como marcadores de desenvolvimento adulto processos subjetivos em conjunto com os processos de transformação de ordem social, cultural e econômica.

Arnett (2000) é um dos que propõem uma visão contemporânea para a fase adulta, baseada no conceito de adultez emergente. Esta se refere ao período entre os 18 e os 25 anos, durante o qual a exploração individual das possibilidades que a vida oferece é maior do que em qualquer outra fase. Segundo o autor, uma das especificidades da idade adulta é a ampla liberdade para as experiências, a legitimidade para explorar possibilidades nos 
relacionamentos afetivos, no trabalho e nas visões de mundo, de forma geral. Emerge, nesse momento, o interesse pela aprendizagem cultural dos códigos de relacionamento, amizade, valores e comportamentos. Também são percebidas diferenças nos adultos na forma de atribuir significado ao trabalho, experiência que vai proporcionar ocupação e renda.

Segundo Brandão, Saraiva e Matos (2012), a emergência da fase adulta coincide com a idade da instabilidade, das possibilidades, das mudanças e das explorações identitárias. As autoras apontam que a instabilidade e as possibilidades características da entrada na fase adulta podem decorrer da conclusão do ensino secundário e, em alguns casos, da saída da casa dos pais. Assim, os jovens podem explorar a educação, o amor e o trabalho de forma mais autônoma.

Trata-se de uma fase marcada por significados ambíguos, por exemplo, a ideia de dependência e independência, a escolha profissional e, ainda, a aquisição de habilidades como o cuidado de si, a responsabilidade e a tomada de decisões (Arnett, 2000). Entretanto, cabe destacar a importância de reconhecer as condições culturais, sociais e econômicas que geram diferenças e desigualdades e, portanto, fazem com que a fase adulta seja experienciada de formas diferentes pelos indivíduos de grupos e classes diversos.

Andrade (2010) aponta que as mudanças sociais têm apresentado novos desafios ao modo como os jovens fazem sua transição para a idade adulta. Numa nova configuração dessa transição, temos visto investimentos mais prolongados na formação escolar, com vistas à realização profissional. Essa condição tende a gerar maior dependência do jovem adulto em relação à família. Deve-se salientar, entretanto, que tal configuração é vivenciada com mais frequência por jovens provenientes de famílias com melhores condições socioeconômicas. Nas famílias de menor potencial socioeconômico, a situação é diversa, pois os jovens enfrentam o desafio da entrada mais precoce no mercado, munidos de menos anos de escolarização. Para 
tornar o quadro ainda mais complicado, a educação para tal parcela de jovens possui menos qualidade e prepara menos para o trabalho, condições que dificultam a inserção em postos de trabalho (Andrade, 2010).

E é na fase adulta que os sistemas de significação podem ser ampliados e diversificados, beneficiando a compreensão do indivíduo sobre o mundo e sobre si, por meio do incremento advindo das vivências em diferentes e mais amplos sistemas e grupos de atividade. Um destaque pode ser dado à construção da identidade, que, na fase adulta, se faz por meio da exploração de opções nos domínios afetivo, social e ocupacional, com vistas à construção de um projeto de vida (Arnett, 2000).

A construção de um cenário no qual o jovem contemporâneo projeta sua vida futura tem na profissionalização uma preocupação importante, já que a transição para a fase adulta é influenciada pela formação e inserção no mercado de trabalho, a qual gera renda e favorece a independência. Diante disso, o ensino superior ganha força como possibilidade de formação que se traduzirá em qualificação profissional e, assim, em importante aspecto do projeto de vida do indivíduo. Ao considerarmos o cenário do ensino superior e as especificidades dos jovens com deficiência, temos a oportunidade de aprofundar nossa reflexão acerca do desenvolvimento de uma parcela específica de jovens. Desperta-nos interesse pensar a experiência do ensino superior como contexto de transição de desenvolvimento, bem como considerar as especificidades do processo quando se trata de pessoas que têm diferentes pontos de partida em relação aos demais estudantes, como no caso daqueles com deficiência. É o que discutimos na seção a seguir. 


\subsection{O ensino superior e o desenvolvimento de estudantes com deficiência}

Considerando a universidade como potencial contexto promotor de desenvolvimento pessoal e profissional, é necessário aprofundar o entendimento de como as relações e experiências nela desenvolvidas afetam a subjetividade dos estudantes com deficiência. A inclusão de jovens com deficiência no espaço universitário gera a necessidade de construção de valores, atitudes que se baseiem na superação dos paradigmas normatizantes que ainda preponderam na sociedade e nas escolas.

As práticas de inclusão numa perspectiva ética são as que se estabelecem na forma de relações horizontais e respeitosas com o outro, favorecendo a colaboração, o diálogo, a valoração positiva que resulta em aceitação das diferenças inerentes à espécie humana (Valsiner, 2012). Assim, a pessoa é compreendida por suas potencialidades, e não em função de suas limitações (Vygotsky, 1995). Conforme destaca Mantoan (2008), a inclusão demanda um novo ambiente educacional, em que as ambiguidades e diferenças não são negadas e desvalorizadas, mas sim compreendidas como possibilidades da existência humana.

Marinho-Araújo (2009) afirma que, no ensino superior, as concepções de sujeito e de desenvolvimento humano, bem como dos processos de ensino e aprendizagem, precisam responder às urgências sociais de cada tempo. Na contemporaneidade, são relevantes questões relativas à escassez de oportunidade, à discriminação, às injustiças e a outros problemas que as universidades são convocadas a enfrentar. Nesse cenário, a universidade é chamada a pautar sua ação no reconhecimento às diferenças e no compromisso em diminuir as desigualdades. Segundo a autora, ainda há importantes compromissos a serem assumidos para tornar o espaço universitário amplamente democrático e capaz de incluir as diferenças e demandas de todos os estudantes, entre eles, os com deficiência (Sousa, Soares \& Evangelista, 2003; Zago, 2011). 
Uma proposta dialógica para as práticas inclusivas toma as diferenças como contexto de atuação. Com isso, entendemos que todos os estudantes têm competências e dificuldades, possibilidades e necessidades, contribuições e demandas, devendo ser acolhidos e acompanhados pedagogicamente em suas peculiaridades e características. Partindo dessa perspectiva dialógica, a escola busca propiciar a participação dos alunos no processo escolar, na medida das capacidades de cada um (Mantoan, 2013; Vygotsky, 1995). Com esse intuito, a educação se abre para considerar que múltiplas possibilidades permeiam a vida do sujeito e comparecem em suas escolhas, participando de suas trajetórias de desenvolvimento (Santos, 2003).

Consideramos multiplicidade como o conjunto de possibilidades de significados, os quais compõem um leque de escolhas que o indivíduo possui e aciona nas situações de mudanças, rupturas, reorientações. A multiplicidade é dialógica e relacional, compondo-se por vários caminhos, em algumas situações em ambivalência, que expressam uma visão particular e subjetiva do mundo (Cunha, 2007).

Para compreender o valor das ambivalências em relação ao desenvolvimento psicológico, apoiamo-nos no trabalho desenvolvido por Abbey e Valsiner (2005), que defendem a importância dessa noção para a compreensão dos processos de desenvolvimento. A definição representa a tensão entre, no mínimo, dois polos que atuam com forças opostas, oferecendo ao indivíduo possibilidades de escolha e apoiando-o em processos de autoorganização. De acordo com a definição de Cunha (2007), a auto-organização é tarefa constante e necessária ao indivíduo; ela decorre do dinamismo dos posicionamentos no sistema I-self, que emergem e se modificam em meio às situações de novidade e reorganização. 
Ao aprofundar a reflexão nas significações que coexistem em tensão e que comparecem na construção dos posicionamentos do self, temos a oportunidade de compreender a trajetória do sujeito adulto. Trata-se de uma forma de conhecer, por meio do foco nas ambivalências, as escolhas e os significados dos sujeitos e como elas se ligam às trajetórias de desenvolvimento. Como exemplo, podemos citar a forma de lidar com os desafios, as experiências novas ou difíceis, que, tensionadas em múltiplas possibilidades, geram a necessidade de escolhas que promovam (ou restituam) a auto-organização ao sujeito (Abbey \& Valsiner, 2005; Cunha, 2007).

\subsection{As ambivalências e as trajetórias de desenvolvimento}

O desenvolvimento é marcado pelas experiências acumuladas pelo indivíduo em sua trajetória. E a força das experiências acumuladas comparece na vida do sujeito no tempo irreversível, o qual integra vivências do passado no presente e num futuro indeterminado (Abbey \& Valsiner, 2005). O desenvolvimento do sujeito adulto, em dado momento de sua linha biográfica, é passível de ser influenciado por um amplo conjunto de possibilidades que ele antecipa, sempre marcado pela incerteza. As antecipações imaginadas, com suas dúvidas inerentes, levam à criação de significados que fomentam o agir no tempo irreversível. Por sua vez, os signos que representam as várias possibilidades atuam em ambivalência (por exemplo, estudar ou não estudar, uma representação de ambivalência que o sujeito projeta para o futuro, ainda incerto, mas que se abre como possibilidade, quando estimado).

As incertezas só se convertem em certezas no tempo presente, pela mediação semiótica, e isso ocorre quando, diante de uma ambivalência, um signo ganha mais força que os outros (Abbey \& Valsiner, 2005). Assim, os signos que emergiram originalmente da 
ambivalência apoiam a composição de significados, que, por sua vez, passam a canalizar as escolhas do indivíduo diante das condições reais relacionadas àquele novo momento portanto, experiências de desenvolvimento, marcadores de sua trajetória adulta. Um exemplo é o aparecimento de uma doença, novo signo em ambivalência, que, pela ruptura com a situação de saúde vivida até então, ganha força e orienta as escolhas do sujeito: estas se dão perante as condições reais do momento, como acesso a tratamento, possibilidades de cura, risco de cronificação etc. Com isso, as escolhas feitas com a intenção de resgatar a auto-organização do sistema de self, mantendo a continuidade no sentido de si, diante das situações de ruptura e transição, participam dos processos de desenvolvimento que compõem a trajetória do sujeito.

Nos processos de desenvolvimento, as experiências de ruptura e transição são (re)organizadoras. São recursos com os quais o sujeito, diante de incertezas e desafios, geralmente tensionados em ambivalência, faz escolhas e reorganiza sua subjetividade, em busca de um sentido de continuidade, e em direção a zonas de estabilidade (Lopes de Oliveira, 2014; Zittoun, 2006, 2007). O conceito de ruptura, conforme a compreensão de Zittoun (2009), implica a ideia de mudança, demandada por elementos catalisadores (forças extrínsecas ou intrínsecas) que guiam o indivíduo na transição para novos significados, para o nunca experimentado (Mattos, 2013; Zittoun, 2009). Transição equivale à ideia de migrar de uma condição a outra, com a construção (ou reconstrução) de significados em substituição àqueles ligados à situação inicial (Zittoun, 2009). A transição se caracteriza como o processo que decorre da ruptura e gera nova configuração de significados, de posições do self. Como já dissemos, ruptura e transição são fenômenos dinâmicos e dialógicos, que tensionam a relação entre certeza e incerteza, permitem a escolha entre múltiplas possibilidades, antecipam o futuro e, no nosso enfoque, desafiam a relação entre eficiência e deficiência, como 
significados em ambivalência que orientam o sujeito e participam do delineamento de sua trajetória (Arnett, 2000; Zittoun, 2009).

É em meio a essa dinâmica relacionada aos significados constituídos nos fenômenos de ruptura-transição que o sujeito se desenvolve, numa organização dialógica. Essa organização se dá em uma trajetória realizada e possível, e um conjunto potencialmente infinito de significados, que organizados em esferas da subjetividade, ora atuam como figura e ora como fundo nos posicionamentos assumidos pelos sujeito.

\subsection{Esferas da subjetividade na compreensão da trajetória de desenvolvimento}

Compreendido o desenvolvimento humano como fenômeno dinâmico e multifacetado, consideramos também a trajetória do sujeito adulto como de crescente complexidade e dinamicidade, perpassada por ambivalências, das quais emergem possibilidades infinitas de novos significados. A variabilidade de caminhos que o desenvolvimento pode tomar com base nos arranjos particulares que as trajetórias biográficas assumem é, tal como temos defendido neste capítulo, fonte de ambivalências. A novidade, a emergência de novos signos e as diferentes orientações que estes podem indicar na vida do sujeito guiam-no rumo a uma trajetória dinâmica e complexa, rica de possibilidades, em que alguns signos tendem a sobressair, como figura, ao passo que outros permanecem como fundo.

Os primeiros signos são parte do "real e possível" da subjetividade. Compõem a esfera que corresponde à superfície e as periferias do sistema de self, região na qual ele está em franca atividade de trocas materiais e simbólicas com a alteridade e a realidade. Na nossa compreensão, os signos ambivalentes que orientam os posicionamentos do sujeito ao longo da vida, embora indicando caminhos e apoiando escolhas, acabam por levar consigo, como 
suplemento imaginado, as escolhas não feitas e as possibilidades não realizadas em diferentes campos de atividade e momentos da vida. As esferas da subjetividade, então organizam a complexidade de significados, formando núcleos de significação e posicionamentos, que respondem à forma principal de atividade do sujeito. Elas envolvem significados que podem haver representado ou continuar a representar marcadores importantes na vida do sujeito, mas que são abandonados temporariamente em prol de uma escolha que, naquelas circunstâncias, passa a canalizar a conduta. Em novas circunstâncias, os signos relacionados às esferas que atuam como fundo podem emergir novamente, com a força de influenciar a direção do desenvolvimento ou mesmo provocar uma guinada na linha biográfica.

A hipótese se mostra de grande valor heurístico para interpretar a capacidade reconstrutiva dos sujeitos em quaisquer circunstâncias e, em especial, nos processos de desenvolvimento que decorrem de eventos ou experiências desorganizadoras ou disruptivas (a exemplo da desorganização ou reconfiguração de funções psicológicas, relacionadas ao desenvolvimento atípico). A relação entre as esferas da subjetividade que ocupam ora o lugar de figura e ora de fundo é dialógica, ou seja, elas formam campos semióticos interdependentes, que se constituem mutuamente, parte da mesma semiosfera (Lotman, 1996). É na articulação dessas esferas em tensão que buscamos perceber a complexidade do desenvolvimento.

De acordo com a proposição, o sujeito orienta-se (subjetiva, intersubjetiva e coletivamente) em um processo de perene negociação de significados entre diferentes esferas da sua subjetividade, em que se define a trajetória. Esta é perpassada e influenciada por outras possibilidades, originárias de outras esferas da subjetividade: aquelas que compõem um quadro indeterminado de escolhas na vida do sujeito. E na dinâmica dos processos de 
desenvolvimento ao longo do tempo, as esferas alternam-se na trajetória do sujeito, ora como figura e ora como fundo.

É importante ressaltar que os processos subjetivos de significação são dinâmicos e estão inseridos em um sistema simbólico maior, que engloba o sistema de crenças e valores sociais sobre o que é normativo. A dinamicidade que permite a construção de significações se dá, segundo Valsiner (2012), porque os indivíduos estão em constante reconstrução de seus mundos intrapsicológicos pela troca de materiais perceptivos e semióticos com o ambiente, tornando o desenvolvimento um fenômeno complexo e dialógico.

E é como fenômeno complexo e dialógico que entendemos o desenvolvimento adulto, que se dá no tempo irreversível e se constitui na reflexividade (recursos acionados para responder à alteridade) e na interação entre as posições assumidas pelo sujeito. O desenvolvimento se constrói na manifestação das ambivalências, nas transições, nas rupturas e na emergência de novidades (Abbey \& Valsiner, 2005; Arnett, 2000; Bastos, 2011; Zittoun, 2009). Todos esses fenômenos possibilitam a produção de sentidos que se apresentam entre as características da pessoa e os contextos em que ela se insere (Kelman, 2010; Valsiner, 2012; Zitttoun, 2009).

Uma forma pela qual podemos conhecer o desenvolvimento é a narrativa autobiográfica (Abbey \& Valsiner, 2005; Bakhtin, 1997; Bamberg, 2008; Bastos, 2011; Lopes de Oliveira, 2014). Sabendo disso, nosso intento é compreender o fenômeno do desenvolvimento humano adulto, especificamente de sujeitos com deficiência, à luz da narrativa de suas trajetórias em duas dimensões. Em uma primeira dimensão, analisando como o fenômeno da deficiência se relaciona às condições de sucesso na trajetória acadêmica. E, na segunda dimensão, identificando posicionamentos e tensões em torno das quais se organizam as trajetórias de desenvolvimento pessoal dos sujeitos. O estudo se compromete em oferecer 
uma compreensão mais ampla do fenômeno, pautada na concretude das vivências dos estudantes e na historicidade dos processos de inclusão no ensino superior.

O trabalho de Bastos (2011) aborda a análise de narrativas autobiográficas, relacionando-as à multilinearidade de trajetórias de desenvolvimento (inspirado no modelo de Sato \& Valsiner, 2010), e apresenta conceitos pertinentes às trajetórias reais e àquelas que a autora denomina trajetórias-sombra. De acordo com Bastos (2011), as trajetórias-sombra são aquelas potenciais, que, embora não realizadas, fazem parte de uma semiosfera comum às trajetórias reais de desenvolvimento. O trabalho da autora inspirou a elaboração das análises que aqui propomos. 


\section{OBJETIVOS}

\section{Objetivo Geral}

- Compreender as dinâmicas de significados e trajetórias de desenvolvimento pessoal de estudantes com deficiências autodeclaradas, mediados pelas experiências subjetivas e institucionais no cotidiano da universidade.

\section{Objetivos Específicos}

- Identificar e analisar os contextos da universidade que visam promover as condições de desenvolvimento acadêmico de estudantes com deficiências.

- Analisar, considerando informações obtidas em narrativas de entrevistas e cartas, os significados que compõem as trajetórias de desenvolvimento pessoal de estudantes com deficiências autodeclaradas na universidade.

- Propor, com base nos resultados do estudo, indicadores que orientem o aprimoramento das metodologias voltadas à inclusão de pessoas com deficiências no ensino superior. 


\section{Metodologia}

Este capítulo apresenta a metodologia adotada neste estudo, abordando o fundamento epistemológico das escolhas teórico-metodológicas e o desenho da pesquisa.

\subsection{Fundamento teórico-metodológico}

O empreendimento de pesquisa qualitativa, no sentido amplo, toma por objeto para reflexão do pesquisador o ser humano em interação, considerando-se sua historicidade dialética e seus contextos de inserção. Ao investirmos esforços explicativos e generalizáveis sobre os fenômenos, julgamos que estes estão carregados de historicidade, das visões de mundo e da subjetividade dos indivíduos (Amado, 2013). Já a definição do objeto na investigação em perspectiva qualitativa envolve uma escolha, que precisa ser clara e capaz de abrir oportunidades interpretativas para a pesquisa. É preciso levar em conta que o objeto:

\footnotetext{
está condicionado por inúmeros fatores, pressupostos e finalidades no campo das ideologias e espiritualidade, implica pessoas concretas, grupos sociais, instituições, implica relações (entre as pessoas, com o conhecimento, com a tradição) e práticas irrepetíveis e mutáveis, implica a constante invenção do futuro, caminha, por tudo o que se disse antes, na onda da utopia enquanto busca do ideal e da perfeição, ou talvez, mais do que isso, caminha no sentido de nos deslocar do lugar em que estamos, demasiado estreito, egoísta e problemático... para um outro lugar, em que o clima se caracterize pela corresponsabilidade, pela solidariedade e pelo respeito aos Direitos Humanos. (Amado, 2013, p. 68).
}

Conforme aponta Amado (2013), o conhecimento se constitui de uma teia de sentidos formulados intra e intersubjetivamente pelos sujeitos e é, por natureza, complexo e multifacetado. Com isso, em pesquisa qualitativa não se tornam necessários modelos rígidos 
de abordagem do objeto e dos dados de pesquisa. Ao contrário, variadas formas e momentos de comunicação e interação humana podem representar oportunidades de construção do conhecimento, considerando-se o destaque à cultura e à singularidade como característica humana (Dias, 2014; Rey, 2005; Rosa \& Valsiner, 2007). O planejamento e a execução dos projetos de investigação, desenvolvidos segundo essa orientação, valem-se de diversas estratégias. De acordo com Flick (2009), somente adotando caráter plural um projeto qualitativo-interpretativo se torna viável e coerente com seus pressupostos e objetivos básicos.

Na pesquisa, a perspectiva cultural foi tomada como matriz norteadora. A cultura, compreendida como produto histórico da ação social humana, funciona como bússola que orienta a ação dos seres humanos. O desenvolvimento está envolto em uma trama de relações sociais, ferramentas, signos comunicativos e discursos que medeiam ou regulam suas atuações. Com isso, o sujeito é regulado pelos significados que dão sentido ao que está sendo feito, a cada momento (Rosa \& Valsiner, 2007).

A visão de sujeito que assumimos é a de um ser relacional, que para ser compreendido necessita ser considerado contra o pano de fundo dos processos de significação. As relações de significados, por sua vez, são construídas em meio aos espaços e contextos socioinstitucionais nos quais o sujeito se insere: família, escola, trabalho, amigos e demais grupos.

Alinhado com os princípios que expomos até aqui, este estudo tomou por objeto as dinâmicas de significação sobre a experiência acadêmica, produzidas pelos sujeitos em situação de entrevista (estudantes e responsáveis pelos serviços de apoio na universidade) e escrita de cartas (estudantes). Os eventos narrados constituíram a base de identificação de significados e posicionamentos em tensão dialógica, e assim nos esforçamos em conhecer os eventos de ruptura e transição que constituíram as trajetórias de desenvolvimento. 
A narrativa como manifestação da linguagem e seus significados nos permitem interpretar os processos de mudança, emergência da novidade, ruptura, reorganização na linha do tempo - portanto, marcadores de desenvolvimento humano. O desenvolvimento é apoiado pelos recursos narrativos acumulados pelo sujeito ao longo da vida (Bruner, 1990). O papel da linguagem nas situações de comunicação é essencial para a construção da experiência subjetiva. E essa importância tende a se manifestar quer pela aquisição da linguagem e dos significados sobre si e sobre o mundo, quer pelas interações com o outro e as possibilidades de desenvolvimento que daí decorrem (Lopes de Oliveira, 2014; Spink \& Menegon, 1999). Por essas características, consideramos que a linguagem, aqui convertida em narrativa, tem viés dialógico e potencial na compreensão dos processos subjetivos.

Labov (1996) define narrativa como qualquer sequência de cláusulas que contém pelo menos um momento temporal e uma técnica verbal para recapitular a experiência. E a construção de unidades narrativas corresponde à sequência temporal da experiência. O autor destaca a importância de sequência, tempo e experiência como elementos constitutivos da narrativa. Ainda nesse sentido, as proposições de Bamberg (2008) destacam a narrativa como experiência pessoal em particular e produção de sentido em geral; em outras palavras, é resultante da experiência pessoal e é representação de algo que aconteceu ou está acontecendo, que teve significado para o narrador e que requer o ato de contar ou representar em uma ocasião especial, sob a forma de uma história particular — a intervenção entre a experiência real e a experiência da história. Ganha destaque o caráter pessoal e social das narrativas, a ligação com as experiências de vida e os processos de significação, bem como o caráter de construção que se coloca entre o real e o imaginado, que se funde no evento narrativo.

Para ampliar a compreensão sobre a narrativa como construção subjetiva e dinâmica, contamos com a contribuição de Riessman (2000), ao afirmar que a narrativa tem como foco 
contar a experiência e não o conteúdo. Com isso, ela não é objetiva, mas assume a posicionalidade e a subjetividade do narrador. Contar histórias é uma atividade relacional, uma prática colaborativa, e assume a existência de contadores e ouvintes que interagem em contextos culturais essenciais para a interpretação. Aqui destacamos a narrativa como construção subjetiva em relação ao vivido, às experiências; como evento dinâmico, a narrativa se posiciona de formas diferentes perante audiências, tempos e contextos.

Nessa linha de compreensão, Lopes de Oliveira (2014) define narrativa como forma de canalização de experiências, organização da memória coletiva, constituição da história social de comunidades e da própria biografia do narrador. Narrar é simultaneamente atividade social, interpessoal e pessoal. É ato de reconstrução do real e de autodescrição, de revelação de si à audiência. Nas narrativas orais e escritas, ouvimos e recontamos nossas histórias e, ao fazê-lo, tomamos consciência de nós mesmos e da própria historicidade em que linhas sociais e pessoais de desenvolvimento se cruzam. A enunciação produz efeitos sobre quem fala, sobre quem escuta e sobre o contexto interacional. As contribuições da autora ressaltam os propósitos das narrativas, organizados segundo a audiência, o contexto ou a motivação.

Como exposto pelo conjunto de autores até aqui, a associação dos estudos de desenvolvimento às narrativas representa uma possibilidade interpretativa dos fenômenos humanos, um meio de acesso à subjetividade convertida em narração, em abordagens microgenéticas. E, com o interesse de compreender o desenvolvimento, por meio de narrativas autobiográficas, destacamos também as proposições de Creswell quando aponta os aspectos de um "bom" estudo narrativo:

- $\quad$ Foca-se em um único indivíduo (ou dois ou três);

- Coleta histórias sobre uma questão significativa relacionada à vida desse indivíduo;

- Desenvolve uma cronologia que conecta diferentes fases ou aspectos de uma história; 
- Conta uma história que relata o que foi dito (temas), como foi dito (o desenrolar da história) e como os interlocutores agem ou encenam a narrativa;

- $\quad$ Coloca-se reflexivamente dentro do estudo. (Creswell, 2014, p. 203)

Por conter os elementos elencados pelo autor, consideramos que nosso estudo se caracteriza como narrativo. Nele, combinamos as histórias de vida, inseridas num contexto sócio-histórico mais amplo, sem o qual a narrativa não pode ser compreendida (Bauer \& Gaskell, 2012; Creswell, 2014).

Do mesmo modo, consideramos que a pesquisa apresenta um viés idiográfico, focado nas experiências singulares dos sujeitos (Valsiner, 2012). Como a pesquisa se orienta pelo interesse em conhecer e compreender as trajetórias acadêmicas dos sujeitos, a perspectiva idiográfica ganha destaque, ao propor a investigação de eventos de vida e dos significados atribuídos pelo sujeito ao vivido, com caráter mais personalizado, individualizado.

\subsection{Desenho e instrumentos}

O estudo propôs-se a articular o sistema de análise numa abordagem qualitativa. Perseguimos uma compreensão mais abrangente dos significados em torno da situação observada (Silverman, 2009), a inclusão de estudantes com deficiência no ensino superior. A figura a seguir esquematiza o desenho metodológico da pesquisa. 
Figura 2 Desenho metodológico da pesquisa

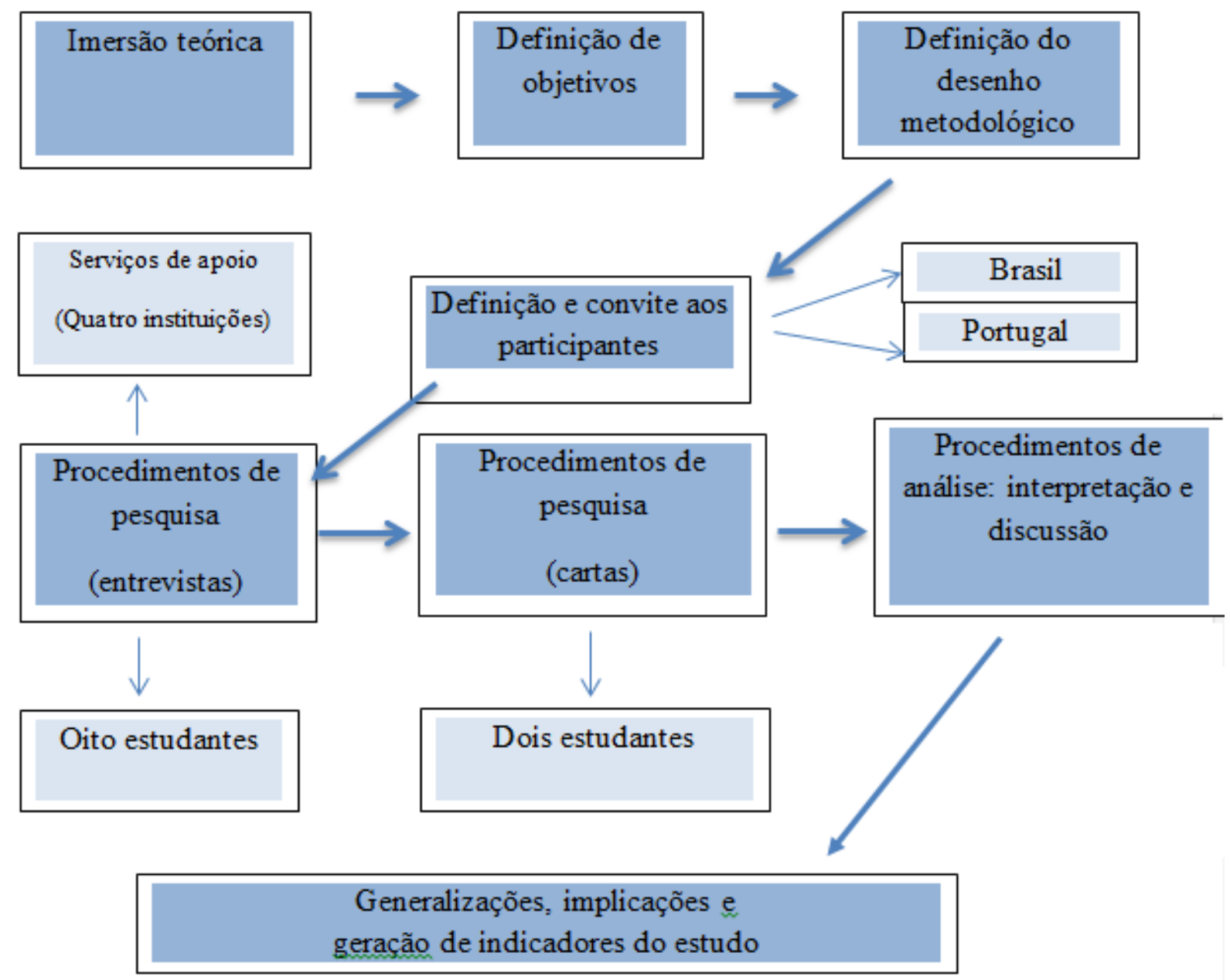

Fonte: Elaboração da pesquisadora

E, assim, elegemos as entrevistas, feitas aos oito estudantes e aos representantes dos sistemas de apoio institucional, e ainda cartas, solicitadas a três dos oito estudantes, para o aprofundamento da análise, em perspectiva idiográfica. A intenção foi utilizar instrumentos metodológicos que respondessem adequadamente aos objetivos formulados, em consonância com a base qualitativa à qual o estudo se filiou. Essa escolha representou uma forma de tentar aproximação com as vivências e os significados atribuídos a elas pelos sujeitos (Valsiner, 2012). 


\subsubsection{Entrevistas}

Em nossa proposição, consideramos a entrevista como uma conversa intencional, orientada por objetivos, com caráter de interação social, que possibilita trocar e construir informações (Amado, 2013; Szymanski, Almeida \& Prandini, 2010). É uma experiência humana que se formaliza no "espaço relacional do conversar" (Maturana, 1993; Szymanski et al., 2010). Na pesquisa qualitativa, a entrevista apresenta-se como proposição aos estudos de significados subjetivos e temas complexos. Por meio dela, torna-se possível acessarmos "fatos, opiniões sobre fatos, sentimentos, planos de ação, condutas atuais ou do passado, motivos conscientes para opiniões e sentimentos" (Szymanski et al., 2010, p. 10). E pelo aspecto relacional, coerente com a ideia de que o significado é construído na interação, elencamos a entrevista como instrumento metodológico adotado no estudo.

Em virtude dos objetivos da pesquisa, foram realizadas entrevistas com dois enfoques: diagnóstico-caracterização (Amado, 2013) e narrativa de vida (Macedo, 2010). A primeira fornece indicadores para a caracterização do processo estudado e, assim, acessa o conhecimento dos entrevistados sobre o tema em estudo (Apêndices 3 e 4). Esse modelo de entrevista foi aplicado aos profissionais envolvidos nos serviços de apoio. O interesse foi identificar as percepções e práticas vivenciadas, relacionadas à organização dos serviços de inclusão na universidade.

O segundo modelo, de narrativa de vida, é aquele no qual interessa "apreender experiências que marcam de maneira significativa a vida de alguém e a definição dessas experiências pela própria pessoa" (Macedo, 2010, p. 106). Conhecer a narrativa de uma situação vivida pelo entrevistado é relevante para a questão de pesquisa. $\mathrm{O}$ foco pode ser a 
história de vida em geral, ou ainda aspectos específicos da biografia do informante (Amado, 2013; Bauer \& Gaskell, 2012; Flick, 2009). O modelo foi aplicado aos estudantes. O interesse foi conhecer as trajetórias acadêmicas dos participantes, conforme consta no roteiro de entrevista (Apêndices 1 e 2).

A pesquisa se concentrou na realização de entrevistas individuais a estudantes com deficiências, a fim de conhecer seus processos de significação da experiência acadêmica, bem como de identificar suas percepções e experiências na incursão pelo ensino superior. $\mathrm{O}$ destaque foram as práticas dos participantes, partindo dos significados sociais e subjetivos a elas relacionados (Amado, 2013; Bauer \& Gaskell, 2012; Creswell, 2014; Flick, 2009; Szymanski et al., 2010).

As entrevistas constituíram instrumentos privilegiados, por oferecerem a oportunidade de melhor conhecer e entender parte da dinâmica institucional, permitirem um contato direto com os interlocutores e suas percepções sobre o problema. Ainda contribuíram para que aspectos subjetivos pudessem ser compartilhados pelos interlocutores, auxiliando a pesquisadora a construir uma explicação fundada na realidade experienciada, em seus contextos educacionais, afetivos e sociais (Ventura, 2007; Zanella, 2013).

\subsubsection{Cartas}

Consideramos que as cartas são recursos comunicativos e metacomunicativos dotados de grande potencial analítico. $\mathrm{O}$ ato de escrever uma carta é ato reflexivo e dialógico, capaz de promover elaboração, ressignificação e antecipação para a vida. Em pesquisa qualitativa, ela é um dos múltiplos instrumentos disponíveis para a construção de informações. Neste estudo, pela abordagem narrativa, as cartas foram escolhidas por representar a oportunidade de 
disponibilizar à pesquisadora o contato com os significados atribuídos pelos sujeitos às próprias vivências.

\subsection{Contextualização}

Uma vez definida a temática da pesquisa, a inclusão de estudantes com deficiência no contexto do ensino superior, fez-se o levantamento e aprofundamento teóricos. Para a revisão

da literatura, buscamos materiais relacionados aos temas "inclusão", "ensino superior" e "desenvolvimento adulto". O trabalho permitiu conhecer melhor o campo, identificando lacunas, indefinições e imprecisões ligadas ao tema. Vislumbrando o cenário e percebendo a escassa produção de pesquisas e informações sobre a inclusão de estudantes com deficiência no ensino superior, nosso passo seguinte foi tentar compor unidades analíticas que permitissem construir o estudo.

Numa primeira tentativa, o estudo buscava conhecer o contexto da inclusão articulando as informações contidas nos documentos e dados censitários nacionais com as práticas das instituições de ensino superior privadas no Distrito Federal. Como a tentativa se mostrou infrutífera, pela não adesão das instituições, houve a necessidade de reorganizarmos o desenho metodológico. A decisão de alteração do desenho foi apoiada pelas professoras avaliadoras no exame de qualificação da pesquisa. Ocorreu ainda, no período, a possibilidade de participação em programa de doutorado sanduíche em Portugal. Lá foi dado andamento à pesquisa, agregando a participação de estudantes e serviços de apoio. Com isso, a pesquisa foi organizada em torno da realização de entrevistas com os técnicos responsáveis pelos serviços para a inclusão nas universidades e, ainda, com a escrita de cartas dos estudantes com deficiência (autodeclarados) à pesquisadora, abordando livremente suas experiências. 
Ao analisar e identificar, entre os estudantes participantes, as histórias que nos chamaram mais a atenção pela riqueza das vivências, convidamos três deles para um segundo momento da pesquisa, em que houve uma aproximação mais idiográfica. O convite foi para que os estudantes escrevessem, após o tempo aproximado de um ano desde a entrevista, uma carta à pesquisadora, contando livremente fatos significativos no período. As cartas foram solicitadas por e-mail e entregues da mesma forma, destacando, entretanto, que, dos três estudantes, uma não atendeu ao convite.

\subsubsection{Critérios de seleção dos participantes}

$\mathrm{O}$ serviço de apoio à inclusão apoiou o contato com os potenciais participantes. $\mathrm{O}$ coordenador fez o convite aos estudantes, disponibilizando o e-mail da pesquisadora para que os interessados pudessem entrar em contato com ela, em setembro de 2013. Com isso, cinco estudantes se manifestaram interessados em participar da pesquisa. Em Portugal, o trâmite ocorreu de forma semelhante, tendo a chefe do gabinete de apoio à inclusão apoiado a realização das entrevistas informais e disponibilizado o e-mail de três estudantes, que foram contatados e aceitaram participar do estudo. Os critérios de seleção estabelecidos foram: ser estudante da universidade; autodeclarar-se estudante com deficiência; declarar a adesão voluntária e o interesse em participar na pesquisa.

Na segunda parte da pesquisa, a escrita da carta, o procedimento se deu da seguinte forma: após as entrevistas com os oito estudantes, foi feita uma análise prévia das histórias que pareceram interessantes para a incursão de aspecto idiográfico. Com isso, três estudantes 
foram selecionados para o aprofundamento do estudo sobre as trajetórias de desenvolvimento e, assim, convidados a escrever uma carta à pesquisadora: João, Maria e Alice. ${ }^{7}$

\subsubsection{Participantes}

A pesquisa contou com a participação de diferentes atores: os responsáveis pelos serviços de apoio à inclusão dos estudantes na universidade e os estudantes com deficiência dos cursos de graduação. Os responsáveis pelos serviços de apoio institucionais foram:

- Universidade A: coordenador do Programa de Apoio à Pessoa com Deficiência, sexo masculino, formado em serviço social, nível técnico, universidade brasileira.

- Universidade B: chefe do Gabinete para a Inclusão, sexo feminino, formada em psicologia, nível técnico, universidade do norte de Portugal.

- Universidade C: chefe dos Serviços de Apoio ao Estudante, sexo feminino, formada em psicologia, nível técnico, universidade do norte de Portugal.

- Universidade D: chefe dos Serviços de Apoio à Inclusão, sexo feminino, formada em psicologia, nível técnico, universidade da região central de Portugal.

Os estudantes que participaram do estudo foram oito, matriculados em cursos de graduação, sendo cinco brasileiros e três portugueses.

Participantes brasileiros:

- Davi: estudante do sexo masculino, 23 anos, cursa o $6^{\circ}$ semestre na área de ciências da natureza $^{8}$, com transtorno do déficit de atenção. Relata dificuldades relacionadas ao

\footnotetext{
${ }^{7}$ Os nomes dos participantes da pesquisa são fictícios.
} 
tempo de realização de atividades em sala. Reside em moradia universitária, tendo a família moradora em outro estado.

- Emília: estudante do sexo feminino, 20 anos, cursa o $5^{\circ}$ semestre em curso na área de ciências humanas, com deficiência física — é cadeirante. Estudante comunicativa, com apurado senso crítico, desportista.

- João: estudante do sexo masculino, 61 anos, cursa o $8^{\circ}$ semestre de curso na área social, com deficiência auditiva. Tem histórico de dificuldades e abandono escolar na juventude. Retomou estudos após os 50 anos, e é atencioso, carismático.

- Maria: estudante do sexo feminino, 20 anos, cursa o $1^{\circ}$ semestre em curso na área de tecnologia, para o qual foi transferida após seis semestres em curso anterior, com deficiência visual. Apresenta histórico de autonomia e bom desempenho escolar, antes de acessar o ensino superior.

- Pedro: estudante do sexo masculino, 27 anos, cursa o $7^{\circ}$ semestre de curso na área social, com transtorno do déficit de atenção e hiperatividade. Tímido, relata dificuldades relacionadas ao acompanhamento das atividades acadêmicas.

\section{Participantes portugueses:}

- Rita: estudante do sexo feminino, 25 anos, cursa o $8^{\circ}$ semestre em área de ciências humanas, com deficiência visual. Estudante dedicada, em adaptação ao espaço da universidade, uma vez que foi transferida recentemente em busca de uma instituição que pudesse oferecer mais oportunidades de inclusão.

\footnotetext{
${ }^{8}$ Por motivos éticos, os cursos em que os participantes estão matriculados foram apresentados de forma genérica, sem detalhes que possam identificá-los.
} 
- Marcelo: estudante do sexo masculino, 25 anos, cursa o $6^{\circ}$ semestre na área de licenciatura, com Síndrome de Asperger. Estudante com perfil relacionado à timidez e insegurança, relata depender da ajuda da mãe em suas atividades de vida.

- Alice: estudante do sexo feminino, 22 anos, cursa o $8^{\circ}$ semestre na área de licenciatura, com dislexia. Relata dificuldades escolares ao longo de toda a sua trajetória. Comunicativa e assertiva.

\subsection{Procedimentos éticos}

Foram observadas as premissas estabelecidas pelo Conselho Nacional de Saúde no tocante às pesquisas com seres humanos. O projeto de pesquisa foi devidamente registrado no sistema Plataforma Brasil, submetido à apreciação do Comitê de Ética em Pesquisa do Instituto de Humanidades da Universidade de Brasília e aprovado em 27 de setembro de 2013, sob o número 433.354 (Anexo 6).

Os cuidados éticos envolveram a preservação dos dados de identificação dos participantes e a garantia de desistência da participação a qualquer momento. Houve também o Termo de Consentimento Livre e Esclarecido (TCLE), lido e assinado pela pesquisadora e pelos participantes no momento das entrevistas (Anexo 5). Para a realização das entrevistas informais, em Portugal, os participantes manifestaram o consentimento de forma oral, após os esclarecimentos feitos pela pesquisadora, e tanto o convite quanto o aceite foram gravados em equipamento de áudio. 


\subsection{Instrumentos e materiais}

Os instrumentos utilizados neste estudo foram:

- Guia geral de entrevista com os estudantes;

- roteiro com questões para entrevista semiestruturada individual com os estudantes;

- guia geral de entrevista com o pessoal do sistema de apoio;

- roteiro com questões para entrevista semiestruturada individual com os responsáveis pelos serviços institucionais de apoio;

- carta escrita pelos estudantes.

Os guias gerais surgiram como ação para a organização dos temas a serem abordados na entrevista. $\mathrm{O}$ instrumento foi elaborado de modo a agrupar os temas, coordenar e dirigir o trabalho, numa organização flexível, que valorizasse a informação (Macedo, 2010). A entrevista na pesquisa qualitativa, por seu caráter relacional e discursivo (Amado, 2013; Denzin \& Lincoln, 2006; Macedo, 2010), permitiu-nos proximidade com os participantes, por isso a consideramos um instrumento adequado e com potencial de contribuir ao estudo.

Por sua vez, os materiais usados no estudo foram formulários em papel A4 — TCLE, roteiro de entrevista e guia geral — e gravador de áudio digital. 


\subsection{Procedimentos de análise}

Por sua natureza dialógica e relacional, a análise de narrativas se apresenta como relevante alternativa metodológica em pesquisas qualitativas. Embora haja variadas técnicas para a análise de narrativas, é reconhecido o seu potencial para compreender as experiências e significações dos sujeitos em contextos culturais (Amado, 2013; Brunner, 1990).

Uma possibilidade considera que a análise de narrativas pessoais tem foco na ação e nos significados individuais e coletivos, bem como nos processos sociais pelos quais a vida social e as relações humanas são feitas e alteradas. A análise de narrativas pessoais refere-se a três perspectivas: toda a história de vida, uma série de materiais autobiográficos; as histórias breves, organizadas em torno de personagens, cenário e enredo, em que se recapitulam eventos específicos, com narração do testemunhado ou experimentado; as grandes seções de conversa em situação de entrevista que contam períodos da vida. Assim, as narrativas podem ser analisadas textualmente, em tom de conversa, cultural, política, histórica e performaticamente. Trata-se de um evento de reciprocidade entre um contador e sua audiência (Riessman, 2000).

Numa outra proposição, formulada por Bamberg (2008), a análise das narrativas se converte no trabalho com pequenas histórias (small stories), opção que se situa entre uma microanálise, a explicação, e uma macroanálise, a descrição. A história é narrada em função do engajamento interacional, abrindo perspectivas sobre as construções identitárias, diante de condições adversas e mudanças constantes. Interessa conhecer, nessa perspectiva, como as pessoas usam pequenas histórias em seus compromissos interativos para construir um senso de quem são, enquanto as grandes histórias analisam suas representações de mundo e identidade.

Lopes de Oliveira $(2006,2012,2014)$ concebe como modelo de análise de narrativa o processo que tem por objetivo compreender a organização subjetiva e investigar o 
desenvolvimento humano. Considera o modo como o sujeito posiciona a si próprio e aos interlocutores, no processo de falar de si e da realidade, destacando os significados comunicados e os processos metacomunicativos. Com isso, o pesquisador pode compreender, por meio das práticas narrativas construídas em situação de pesquisa, a formação e transformação da subjetividade.

Coerente com as proposições dos autores aqui evocados, buscamos inserir nossa proposta no campo das análises de narrativas. Acreditamos que essa estratégia teóricometodológica se coaduna com o objetivo de analisar os significados que perpassam pelos processos de desenvolvimento de estudantes com deficiência, de forma a lançar luz sobre a construção das identidades e as imagens que os indivíduos têm de si mesmos e de suas trajetórias.

De antemão destacamos que temos consciência de que nosso trabalho tem um alcance limitado, por abordar temática, contexto, tempo e enredos específicos. Por isso, não tem a intenção de compor um modelo explicativo amplo para a compreensão do fenômeno da inclusão no ensino superior. Apresenta, tomando como ponto de partida as narrativas decorrentes de entrevistas, como a trajetória estudantil do indivíduo é suscitada por sua subjetividade, em meio ao sistema de significados e ao contexto em que está inserido. E acrescenta que, mediante as narrativas, é possível compreender as manifestações singulares e os processos de desenvolvimento experienciados pelos estudantes.

O estudo buscou considerar ainda outras possibilidades de manifestação da linguagem que se fizeram presentes na construção das informações e que excederam a realização das entrevistas. No processo de construção das informações, buscamos atentar para as interações informais anteriores e posteriores às entrevistas: o ambiente estabelecido, a forma como os sujeitos se apresentaram para a atividade, o interesse demonstrado, as expressões não verbais. 
Igualmente atentamos às manifestações metacomunicativas da narrativa, como ênfases, desânimos, repetições, silêncios, risos, olhares e gestos que, a nosso ver, compuseram também o corpus de informações a analisar.

Os temas abordados foram distribuídos em três eixos: discursos e práticas institucionais das universidades; vozes dos estudantes e desafios perante a inclusão; narrativas provenientes das entrevistas individuais e das cartas.

Nossa pretensão foi adotar procedimentos de análise coerentes com a perspectiva qualitativa de interpretação dos fenômenos. Procuramos identificar as questões da subjetividade dos participantes e os contextos sociais, utilizar a análise como mecanismo de compreensão do processo, manter os cuidados com a transcrição, exercer os atos de transcrever, reviver e analisar, e, ainda, recorrer à categorização como mecanismo de construção de saberes críticos, criativos e significativos (Creswell, 2014; Zanella, 2013).

Com a análise dos dados, buscamos ordenar o conhecimento resultante da pesquisa e redigi-lo como texto capaz de representar o processo, nos significados negociados entre pesquisadora e participantes. Podemos afirmar que, numa perspectiva dialógica, foi um processo de coconstrução, em que tanto a pesquisadora quanto o participante significaram e ressignificaram seus saberes e suas compreensões de mundo.

O estudo propiciou, de modo particular, condições para aprofundar o conhecimento sobre trajetórias de desenvolvimento de indivíduos com deficiência ao longo do curso de graduação, num esforço detalhado e sistêmico. O intuito foi estabelecer possibilidades significativas de análise: significados em tensão, eventos de ruptura e transição, aspectos facilitadores e dificultadores da experiência acadêmica, configuração de trajetórias-figura e trajetórias-fundo. 
Acreditamos que o desenho metodológico do estudo permitiu a aproximação necessária à nossa abordagem, bem como ampliou as possibilidades de análise e reflexão sobre o fenômeno da inclusão no ensino superior. A metodologia qualitativa, de caráter idiográfico, mostrou-se relevante à nossa proposição de compreender as dinâmicas de significação e as trajetórias de desenvolvimento dos jovens com deficiência no ensino superior. 


\section{RESULTADOS}

\section{ATUAÇÃo E CONTRIBUTOS dOS SISTEMAS DE APOIO À INCLUSÃo NO ENSINO SUPERIOR $^{910}$}

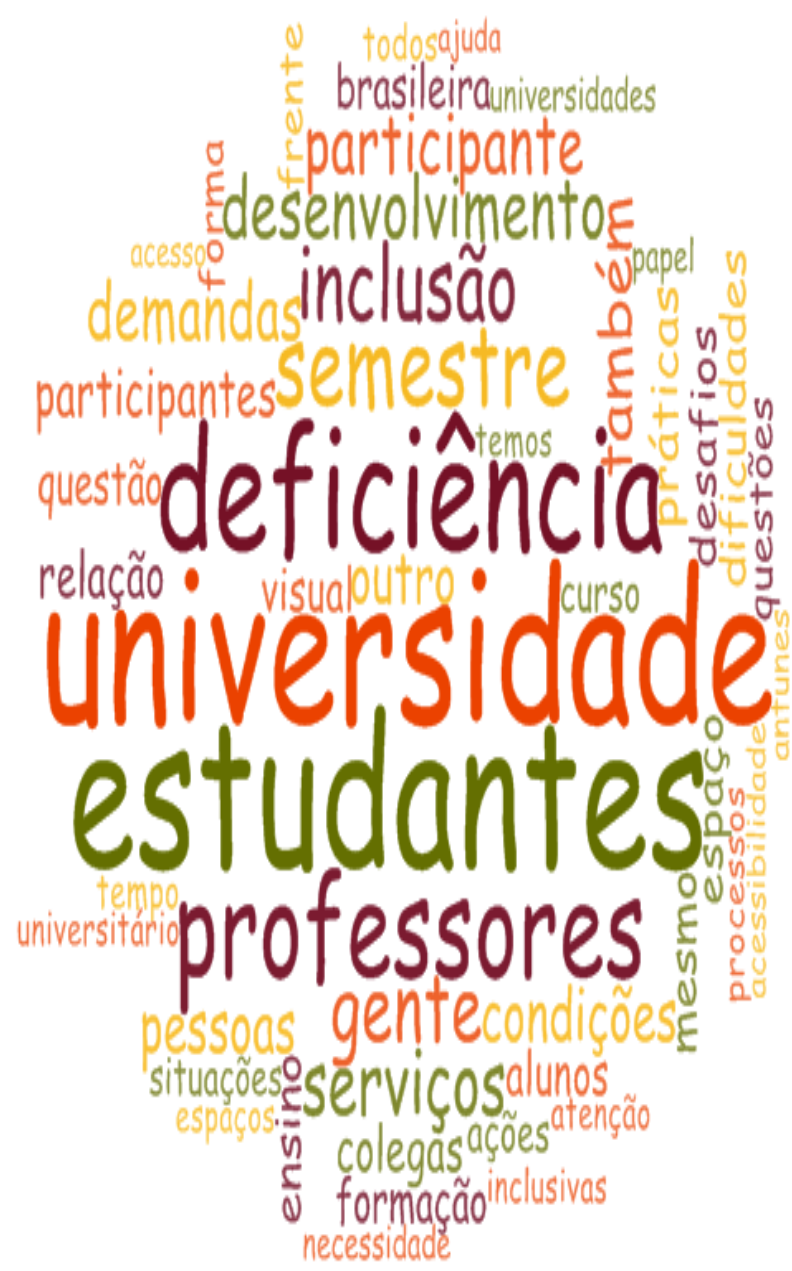

\footnotetext{
${ }^{9}$ Alguns temas em exposição neste capítulo compuseram o manuscrito inédito Modelos de atuação e contributos dos sistemas de apoio à inclusão no ensino superior português, de autoria de Ana Claudia Rodrigues Fernandes, Maria Cláudia Santos Lopes de Oliveira e Leandro da Silva Almeida (2014).

10 Nuvem de palavras elaborada com o uso do software NVivo 10, em que considerando as narrativas de entrevista, foram selecionadas as cinquenta palavras com maior ocorrência. Ao centro e em maior tamanho as palavras mais frequentes.
} 
As universidades têm recorrido a diferentes iniciativas para responder às demandas por serviços que apoiem o acesso de estudantes com deficiência e, ainda, oferecer adequadas condições de permanência (Abreu \& Antunes, 2013; Antunes \& Faria, 2013; Fernandes \& Almeida, 2007; Santos, 2013). Interessa-nos, neste capítulo, conhecer como estão organizadas as iniciativas institucionais de inclusão no ensino superior, tomando como objeto os serviços de apoio criados por uma universidade brasileira e três universidades portuguesas.

Como instrumento para a recolha das informações, foi conduzida entrevista semiestruturada com profissionais que atuam nos referidos serviços. Averiguou-se seu conhecimento, suas experiências, suas práticas e percepções em relação ao tema em investigação (Amado, 2013; Creswell, 2014; Flick, 2009). As entrevistas, do tipo diagnósticocaracterização (Amado, 2013), abordaram: a história da criação dos serviços de apoio na universidade; os tipos de serviço ofertados; a adesão dos estudantes aos serviços; e os desafios enfrentados diante das demandas dos estudantes.

\subsection{Os sistemas e sua atuação: Múltiplos olhares e ações}

Em nossa incursão nas universidades para a realização da pesquisa, foi possível perceber que concepções e olhares para o fenômeno da inclusão orientam os trabalhos, ao mesmo tempo em que sugerem sentidos e significados aos usuários dos serviços. As iniciativas guardam aproximações (acolhimento e suporte às atividades de vida estudantil, apoio na produção de material adaptado); porém, também são percebidas especificidades do modelo adotado em cada instituição (foco na autonomia, adaptações curriculares, programa de tutoria especial, entre outros). Acreditamos que as especificidades revelam tanto a forma como 
a universidade se vê impulsionada a responder às demandas dos estudantes quanto aos significados institucionais de inclusão.

De início, destacamos o tema da base legal para a inclusão no ensino superior. No Brasil, há um arcabouço legal que subsidia e regula programas e ações afirmativas para a inclusão no ensino superior. Portugal ainda não conta com tal arcabouço voltado às práticas nesse nível de ensino. Conforme já mencionamos nesta tese, a falta de regulamentação faz com que as ações se pautem nas práticas direcionadas aos demais níveis de ensino e, ainda, em iniciativas das universidades (Abreu \& Antunes, 2013; Antunes \& Faria, 2013). A esse respeito, uma participante expôs:

"era importante que houvesse uma legislação do nosso Ministério da Educação que obrigasse as instituições de ensino superior, todas, a atuar de determinada forma para haver congruência de esforços de todas as instituições e para haver real apoio" (Participante B, universidade portuguesa).

A falta de arcabouço legal fez surgir uma iniciativa de organização das universidades em torno das demandas inclusivas em Portugal. Foi criado o GTAEDES, grupo de trabalho que reúne dez universidades e instituições no país que têm ligação com a organização e atuação no ensino superior, como Ministério de Educação e Ministério de Tecnologia, e promove ações para a inclusão em contexto universitário. O grupo tem alcançado importantes resultados naquele país.

A iniciativa da criação do grupo representa um esforço positivo em aspectos acadêmicos, políticos e organizacionais, que pode inspirar ações no Brasil. São exemplos de ações do GTAEDES que podem gerar a articulação em rede para orientar as ações: o contato e a parceria com os ministérios de Educação e Tecnologia e o Instituto Nacional para a Reabilitação (INR); a criação de um sistema de consulta on-line com as instituições do país que possuem serviços de apoio aos estudantes com deficiência; a realização de ações 
conjuntas; o estabelecimento de um fórum permanente de troca de experiências; a disponibilização de uma biblioteca on-line acessível e aberta ${ }^{11}$.

Como vimos, várias são as iniciativas de inclusão no espaço da universidade. Quando voltamos nossa atenção aos relatos dos participantes, elencamos alguns temas, sobre os quais organizamos nossa análise: os tipos de serviços ofertados para o apoio à inclusão na universidade; o apoio em demandas de vida cotidiana e a mobilidade no campus; o suporte e incentivo à autonomia no espaço universitário; e as ações de sensibilização e formação.

Quanto aos tipos de serviços ofertados para o apoio à inclusão na universidade, a experiência da instituição brasileira informa que as ações têm como foco as demandas dos estudantes:

[...] o aluno é cego, ele não vai ler a prova... A gente pode proporcionar meios que ele tenha acesso a este conteúdo, e aí a gente entra com a questão do BRAILE, do próprio ledor, do tutor, que vai dar este apoio para ele... Trabalhamos em vários eixos, no eixo do apoio acadêmico, que é um dos principais, com programa de tutoria especial, no qual os alunos que necessitam têm tutores em sala de aula, e fora, para adaptar material, passar conteúdo, uma espécie de estudo compartilhado e complementar... ((Participante A, universidade brasileira).

O rol de atividades inclui principalmente: (i) estabelecimento de contato com os alunos; (ii) esclarecimento de dúvidas sobre a universidade e seu funcionamento; (iii) mediação junto aos professores para condições especiais de frequência e avaliação dos estudantes; (iv) articulação com outros setores da universidade para a resolução de problemas e disponibilização de apoios (acompanhamento acadêmico, programa de tutoria especial, transporte no campus, por exemplo); (v) disponibilização de tecnologias de apoio em espaços da universidade (laboratório de ampliação e adaptação de materiais para pessoas com deficiência visual, biblioteca digital e sonora); (vi) eliminação de barreiras arquitetônicas; (vii) acesso a materiais de estudo adaptados.

\footnotetext{
${ }^{11}$ Disponível em: http://gtaedes.ul.pt. Acesso em: 25.set.2015.
} 
Os serviços de inclusão em Portugal têm buscado organizar suas ações com foco nas demandas dos estudantes. O viés institucional é marcado pela busca de parcerias para atendimento (por exemplo, com associações voltadas ao atendimento de pessoas com deficiência) e pela promoção de ações de sensibilização da comunidade universitária, embora seja destaque nas falas das participantes a baixa adesão às iniciativas.

Depende muito dos casos. Mas, por norma, condições especiais de avaliação. Em cada caso... no caso dos alunos com deficiência visual, têm sido os materiais adaptados e algumas dificuldades em termos de acessibilidade. Para os alunos com mobilidade condicionada, os apoios são o estacionamento mais próximo possível, salas reservadas ou salas mais próximas da entrada, em pisos térreos, mais próximas umas das outras, para evitar deslocamentos nos diferentes pisos, e tentamos responder a esses pedidos para não haver essa dificuldade. No caso de alunos com Síndrome de Asperger, temos mais problemas, pois há a necessidade de adaptação dos testes (Participante D, universidade portuguesa).

De forma mais específica, as ações para o atendimento às demandas individuais têm o intento de criar condições para o desempenho regular dos estudantes. No plano de atividades, as ações são respostas aos pedidos de apoio e se concentram em: (i) estabelecimento de contato com docentes; (ii) esclarecimento de dúvidas e ações de informação solicitadas pelos docentes; (iii) garantia de condições especiais de frequência e avaliação aos estudantes; (iv) articulação com outros serviços para a resolução de problemas; (v) empréstimo de tecnologias de apoio ou sua colocação em sala de aula; (vi) sinalização da necessidade de eliminar barreiras físicas; (vii) organização e encaminhamento de pedidos de vagas adicionais para transferência ou mudança de curso; (viii) acesso a materiais de estudo. Entretanto, cada instituição acaba por compor um campo de atuação diferenciado, pautado em formas específicas de compreender e efetivar a inclusão, o que traz consequências na forma de atribuir significado à deficiência e de sugerir ações. 
Cremos que os sistemas organizados de forma a possibilitar a compensação de limitações, no nosso caso pela disponibilização de materiais e adequação de recursos, amplia as oportunidades de inserção e aprendizagens dos estudantes, uma vez que minimiza suas desvantagens (Vygotsky, 1993). Entretanto, outros aspectos concorrem para tornar a universidade inclusiva: concepções, valores, crenças e atitudes dos sujeitos perante a deficiência.

Quanto ao apoio em demandas de vida cotidiana e mobilidade no espaço da universidade, os participantes mencionaram os recursos técnicos (aplicativos, mouses adaptados, lupas), humanos (tradutores para língua de sinais, pessoas encarregadas da digitalização de textos impressos), econômicos (verbas para transporte e pagamento de serviços de terceiros) e arquitetônicos.

Aqui temos diversos equipamentos disponíveis. São programas de leitura de ecrã ${ }^{12}$, ampliação de ecrã, linha Braille, lupas portáteis, computadores, virador de página, teclado de conceitos, mouse adaptado, scanner com programa de reconhecimento de caracteres adaptados às pessoas com deficiência da visão. (Participante $\mathrm{B}$, universidade portuguesa).

Nós temos uma planilha de custos que cobre apoios em língua gestual, técnicas de mobilidade e orientação para ensinar os espaços, o técnico é usado para isso, pessoas para a produção de informação. Eventualmente também podemos cobrir despesas de transporte em situações muito específicas. Assim estão assegurados os apoios fundamentais para o aluno estar aqui. (Participante D, universidade portuguesa).

E o apoio estrutural, a gente faz um policiamento no campus para que haja as adaptações, para que os prédios novos não precisem ser adaptados, já sejam concebidos dentro da política de universalidade, e enfim, esse tipo de briga... se aqui no [nome do prédio], um prédio muito trabalhoso, uma pessoa com deficiência é colocada numa sala inadequada, a gente procura fazer a transferência [...].(Participante A, universidade brasileira).

As ações visam minimizar as desvantagens que a deficiência pode impor ao estudante no que se refere ao acesso ao ambiente, ao deslocamento nele e à aproximação ao conteúdo acadêmico. Os participantes apresentaram as iniciativas de diminuição das barreiras como

\footnotetext{
${ }^{12}$ Tela do computador.
} 
importantes para a organização da inclusão em contexto acadêmico. Considerando o desenvolvimento dos estudantes, nosso destaque recai sobre a organização dos sistemas de apoio como instrumentos promotores do senso de pertença ao ambiente universitário, do desenvolvimento do sentido de si, da valorização das próprias habilidades e, ainda, da ressignificação de limites e possibilidades. As ações que têm como foco a acessibilidade e a mobilidade são relevantes para isso, mas há também demandas por outros tipos de iniciativas (Fischer, 2014; Valle \& Connor, 2014).

Considerando a complexidade da inserção dos estudantes com deficiência no contexto universitário, é certo que práticas que permitam ao sujeito atuar de forma ativa e autônoma constituem mecanismos de apoio aos processos de desenvolvimento. O suporte e o incentivo à autonomia no espaço universitário foi um tema que percebemos no enunciado de participantes do estudo, que apresentam a forma como a universidade traduz a questão.

Nós aqui temos que estruturar as nossas ações desde o momento em que o aluno chega. No primeiro ano, é um ano de integração, nós temos que apoiar os nossos alunos ao máximo, permitir que eles ultrapassem aquela situação de mudança de ensino e aí criar o máximo de condições possíveis para que ele o possa fazer. No segundo ano, devemos tentar que seja ele a organizar os seus serviços, ou seja, com nosso apoio, conosco vão conversar com as pessoas, contatar as pessoas para saber que apoios é que podem ter, contatar os técnicos que podem, mobilizar os colegas para poderem fazer o trabalho conosco. E no último ano serem eles mesmos a trazerem as soluções (Participante D, universidade portuguesa).

O aluno tem que ter a iniciativa de se integrar e se envolver com os colegas e nós chamamos a atenção para isso também. Se ele quiser apoio para isso, tiver alguma dificuldade em especial, nós ajudamos com o apoio psicológico (Participante B, universidade portuguesa).

Da fala da participante $\mathrm{D}$, inferimos que nessa universidade a autonomia é um signo hipergeneralizado e uma exigência a ser evidenciada pelos estudantes. Como temos afirmado, constituir-se como estudante com deficiência no complexo contexto de desenvolvimento que é a universidade representa um desafio significativo. Para responder de forma esperada, o 
sujeito aciona mecanismos e estratégias para lidar com a realidade e suas contradições. E um dos mecanismos que se espera é o exercício da autonomia em torno da experiência estudantil. Se por um lado esse exercício pode beneficiar os processos de desenvolvimento do sujeito, permitindo atuar com agência, fazer escolhas e lidar com as possibilidades e incertezas do futuro (Abbey \& Valsiner, 2005), por outro, sua exigência pode prejudicar os processos.

A autonomia pode ser entendida como construção pautada no respeito às singularidades e potencialidades do indivíduo. Contudo, quando ela passa a representar uma exigência, uma atitude esperada do indivíduo, vemos em risco o seu benefício. Se for internalizada pelo sujeito como uma demanda a atender, a autonomia tende a impactar suas significações para o constituir-se acadêmico, e vemos casos em que estudantes se negam a receber uma ajuda que poderia garantir condições mais equânimes de permanência na universidade.

Tomando os signos hipergeneralizados que se associam ao ofício de estudante universitário (Coulon, 2008), temos como destaque eficiência, mérito e autonomia. São esperadas dos estudantes capacidades de lidar com as ambivalências, os impasses e os desafios próprios da experiência acadêmica. Entretanto, para os estudantes com deficiência, o desafio se torna maior, pois, além dos signos hipergeneralizados relacionados à vida acadêmica, recai sobre eles a demanda por comprovação de capacidade e eficiência, que afirme sua competência para ser reconhecidos como estudantes do ensino superior (Coulon, 2008; Valle \& Connor, 2014). A autonomia representa um desafio a vencer com os estudantes, com respeito às singularidades, habilidades e potencialidades dos sujeitos, fazendo com que a inclusão possa adotar um caráter mais subjetivo, menos generalista. O objetivo dos serviços ofertados relaciona-se às vivências na universidade: êxito nas experiências, ampliando as 
oportunidades de construção de autonomia, bem como de sucesso acadêmico e pessoal (Antunes \& Faria, 2013; Fernandes, Almeida \& Mourão, 2007).

As iniciativas dos serviços de apoio nas universidades visitadas contemplam diferentes concepções e realidades vivenciadas pelas universidades, e ainda suas formas de responder à demanda:

no formulário de solicitação de apoio, há um espaço para o estudante indicar os tipos de apoio que acha que vai precisar. $\mathrm{E}$ o formulário vai ser discutido na reunião. $\mathrm{O}$ diretor de curso vai tentar perceber as necessidades na reunião e, por outro lado, verificar como o estudante vai se adequar aos programas. Os apoios são decididos em conjunto. E nesse momento emerge a grande dificuldade desses estudantes. Eles não estão acostumados a negociar apoios, estão habituados a receber apoios. (Participante C, universidade portuguesa).

A exposição aponta a forma como a universidade portuguesa compreende os serviços que oferta e, ainda, o papel esperado do estudante. Os serviços visam acompanhar o estudante em sua incursão na universidade. Para isso, espera-se do estudante um perfil autônomo em assumir e indicar suas demandas, e ainda ativo em participar, decidir "em conjunto", adequarse e negociar o atendimento às suas demandas. Fischer (2014) indica o envolvimento de todos os atores na universidade na inclusão como elemento facilitador das mudanças. Entretanto, como já afirmado, a autonomia precisa assumir o caráter de construção e não de exigência.

A partir do momento que a pessoa entra na universidade, ela não é automaticamente cadastrada no programa, porque o programa é facultativo, não é uma coisa compulsória. Quando sai a lista dos vestibulandos, a gente confere quem pediu atendimento especial, junto ao [órgão de seleção]. A partir daí a gente estabelece um primeiro contato, explica como é o programa, em que ele pode ajudar, deixa à disposição para que, a qualquer momento, o universitário faça seu cadastro, sendo uma decisão dele se cadastrar. (participante A, universidade brasileira).

$\mathrm{Na}$ universidade brasileira, os serviços destinam-se a assistir o estudante em sua chegada e permanência. Para isso, esperam dele a solicitação de cadastro e "ajuda". Em outras palavras, a universidade espera que o sujeito veja a si como necessitado ou não do suporte. 
Mas essa forma de organizar os serviços disponíveis para a pessoa com deficiência na universidade pode ser problematizada. Se por um lado pode ser compreendida como humana e respeitosa, por outro, pode colocar o sujeito em condição de diferença e evidência. Concepções dessa natureza podem associar deficiência a processos de ação que, sob o pretexto da inclusão, diferenciam, impõem marcas (Goffman, 1988).

A subjetividade dos jovens estudantes e suas demandas têm destaque no que se refere à permanência e ao aproveitamento acadêmico. Constitui um desafio articular as respostas esperadas (associadas à meritocracia) a práticas inclusivas capazes de guardar e respeitar o caráter subjetivo, notadamente necessário ao desenvolvimento pessoal e social dos indivíduos.

A concepção da universidade sobre a inclusão é importante orientadora das práticas e dos valores estabelecidos. Nesse aspecto, Marinho-Araújo (2009) salienta que, no ensino superior, as concepções de sujeito, de desenvolvimento humano, bem como dos processos de ensino e aprendizagem, precisam responder às urgências sociais resultantes de faltas de oportunidade, discriminação, injustiças e outros problemas que as universidades são convocadas a enfrentar. E isso vai ao encontro da promoção de igualdade de oportunidades e respeito à singularidade.

O tema da inclusão é complexo. Demanda ações e mudanças culturais na instituição, e não apenas com foco nas pessoas com deficiência. A iniciativa de inclusão centrada na pessoa com deficiência rotula o sujeito como diferente e pode associar-se a menos-valia, incapacidade. Em iniciativas mais amplas, que alcancem a universidade como um todo, há possibilidade de (re)significação da ética e exercício do respeito às diferenças, beneficiando a todos em seus processos formativos. As universidades são convidadas a pautar sua ação no reconhecimento às diferenças e no compromisso em diminuir as desigualdades, promovendo o 
aproveitamento da experiência acadêmica e o exercício da cidadania (Antunes \& Almeida, 2012; Bisinoto \& Marinho-Araújo, 2014; Fischer, 2014; Silva, Ferreira \& Ferreira, 2014).

$\mathrm{Na}$ consecução dos objetivos de construção de um modelo inclusivo com as características que apontamos acima, um tema emerge como relevante e carente de atenção: o papel do professor. Os participantes da pesquisa enfatizaram que garantir condições adequadas de aprendizagem depende não apenas dos recursos providos pelos sistemas de apoio, mas fundamentalmente do empenho dos docentes:

eles [os alunos] reclamam da mobilidade, os materiais, as relações com professores (Participante B, universidade portuguesa).

Há situações em que professores não entendem ou exigem desse aluno a mesma capacidade que o outro demonstrou. Como qualquer ser humano, independentemente da nossa condição, na verdade uns somos diferentes dos outros [...]. Mas para aquele professor que está ali a primeira impressão é essa, ou seja, como é possível que o Antonio não consiga fazer as mesmas coisas que o José fez? Às vezes, criamos estas comparações e isso é uma dificuldade, porque as exigências, expectativas, tornam-se mais elevadas. (Participante D, universidade portuguesa).

Os professores têm que perceber que estão em um contexto de diversidade (Participante $\mathrm{C}$, universidade portuguesa).

A formação dos professores, inicial e continuada, é peça-chave na consecução de ações inclusivas na universidade, um tema destacado também pelos estudantes que participam da pesquisa $^{13}$. Afinal, é do professor, em última instância, o papel de transformar a inclusão em ações (Fischer, 2014; Pieczkowski \& Naujorks, 2012; Valle \& Connor, 2014). Pieczkowski e Naujorks (2012) consideram fundamental promover uma formação para a inclusão que contemple os docentes universitários. A capacitação dos professores ganha destaque como investimento para a obtenção de sucesso educativo, fundamentado na diversidade humana (Fischer, 2014; Moreira, 2010). As práticas inclusivas com alunos com deficiência exigem

\footnotetext{
${ }^{13}$ Para mais informações sobre o tema da formação de professores, ver o capítulo 8.
} 
formação e compreensão aprofundada e reflexiva, uma vez que incidirão diretamente sobre os significados e os processos de desenvolvimento atribuídos à experiência acadêmica.

Além do tema da formação docente e o destaque ao papel do professor, a aceitação das diferenças e as atitudes de preconceito emergem das enunciações dos participantes como desafios:

isso tem a ver com a mudança de atitude e, antes disso, com a mudança de mentalidade. [...] O problema é que, apesar de hoje em dia estarmos quase sufocados de informação, em todo o lado, e de a deficiência ser um tema que já vem sendo tratado em todos os canais de comunicação, muitas vezes a mensagem correta não chega às pessoas a quem mais deveria chegar. E, portanto, o que acontece ainda é que há muita ignorância e muita mistificação em torno da deficiência. (Participante B, universidade portuguesa).

Esse é o grande desafio, é fazer com que a deficiência não seja um fator de exclusão em momento nenhum [...]. A partir do momento que o sistema de educação, do infantil até o médio, for inclusivo, eu acho que a gente não vai ter tantos problemas assim (participante A, universidade brasileira).

A inclusão no ensino superior, espaço definido pela competência e pelo mérito, aponta para preconceitos, crenças e valores sociais e pessoais de uma sociedade baseada em modelos de normalidade e competição altamente excludentes (Dias \& Lopes de Oliveira, 2014; Mantoan, 2013; Sousa Santos, 2005). Como apontado pelos participantes, os desafios perpassam pela ressignificação de preconceitos e atitudes na universidade, que atuam como signos hipergeneralizados de menos-valia, incompletude, incapacidade. Compreensões da deficiência como materialização da diferença e das múltiplas possibilidades de vida e desenvolvimento humano se apresentam como alternativas à disseminação de valores e práticas mais éticos e inclusivos (Moreira, 2010; Valle \& Connor, 2014). Já ambientes pouco receptivos e pouco estimulantes, barreiras físicas e arquitetônicas, discriminação, e falta de informação e de serviços de apoio podem influenciar negativamente a trajetória dos jovens, chegando a provocar dificuldades e até abandono (Abreu \& Antunes, 2013; Fernandes \& 
Almeida, 2007). Entretanto, ao ampliar oportunidades de respeito e condições equânimes de desenvolvimento, favorecemos o sucesso acadêmico e pessoal dos sujeitos (Antunes \& Faria, 2013; Fernandes, Almeida \& Mourão, 2007).

Em ambos os contextos em investigação, Brasil e Portugal, há demanda por serviços de apoio que respondam às demandas dos estudantes, como forma de possibilitar melhores condições de aprendizagem, permanência, sucesso escolar e desenvolvimento (Abreu \& Antunes, 2013; Fischer, 2014). Atitudes inclusivas no contexto universitário favorecem as condições de permanência e aproveitamento, e apoiam os processos de desenvolvimento (Abreu \& Antunes, 2013; Almeida, Costa, Alves, Gonçalves \& Araújo, 2012; Anache, 2007; Del Prette \& Del Prette, 1998; Dias \& Lopes de Oliveira, 2013; Fernandes \& Almeida, 2007). Percebemos diferenças e aproximações entre os cenários de Brasil e Portugal, embora tenhamos ciência do alcance limitado da investigação. Os destaques apontados, de forma geral, informaram os desafios que se impõem na ampliação e qualificação do sistema de apoio; mostraram, ainda, como as ações institucionais voltadas à inclusão interferem diretamente nos processos de desenvolvimento dos sujeitos. 


\section{A UNIVERSIDADE NA VOZ DOS ESTUDANTES: DESAFIOS À INCLUSÃO ${ }^{1415}$}

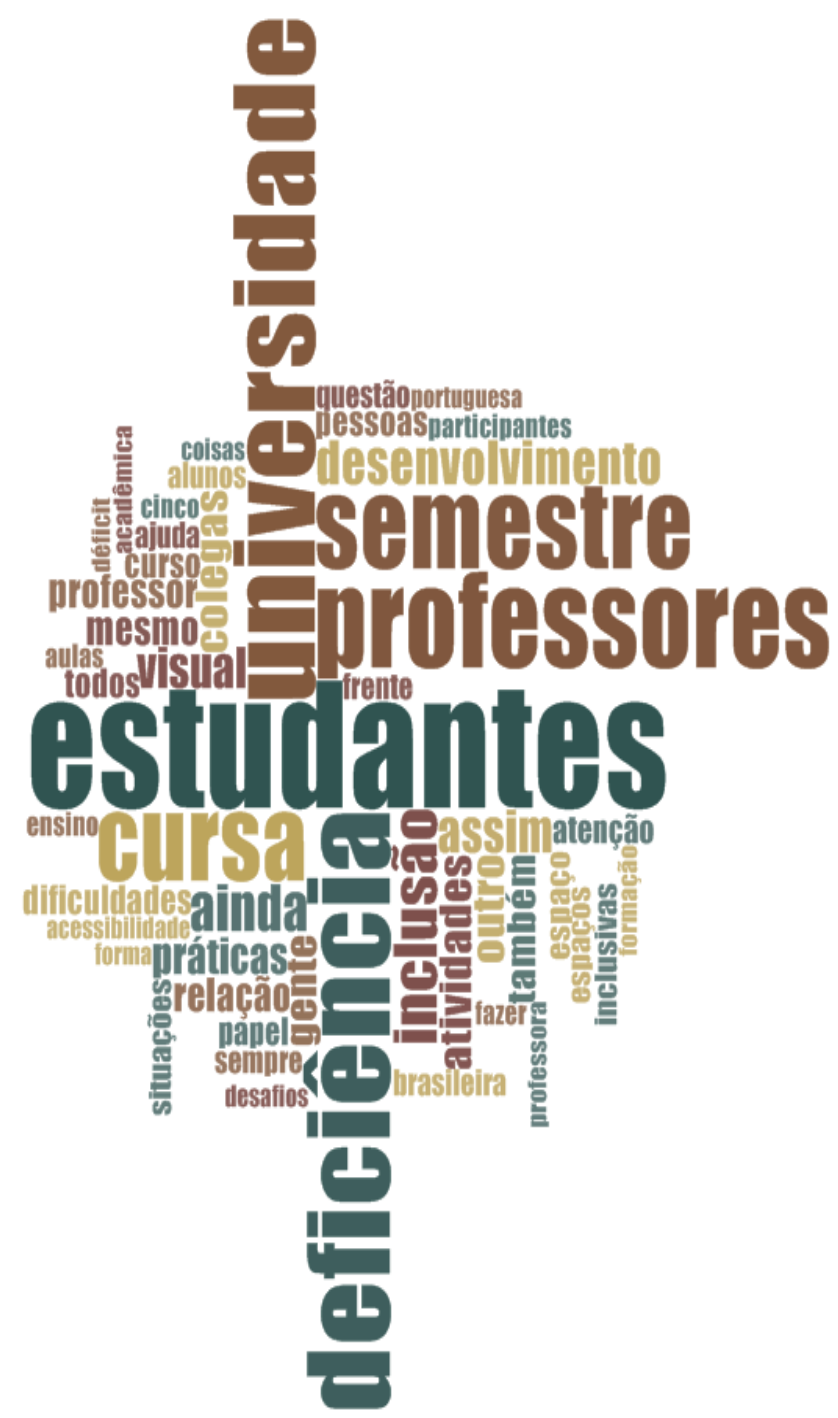

\footnotetext{
${ }^{14}$ Neste capítulo, alguns temas compuseram o capítulo do livro Práticas Sociais, Políticas Públicas e Direitos Humanos (2015), sob o título Desafios da inclusão escolar/social de jovens no Ensino Superior: significações acerca do Programa de Apoio às Pessoas com Necessidades Especiais da Universidade de Brasília, de autoria da doutoranda Ana Claudia Fernandes e da orientadora Maria Cláudia Santos Lopes de Oliveira, publicado pela Editora Abrapso.

15 Nuvem de palavras elaborada com o uso do software NVivo 10, em que considerando as narrativas de entrevista, foram selecionadas as cinquenta palavras com maior ocorrência. Ao centro e em maior tamanho as palavras mais frequentes.
} 
Para compreender as trajetórias dos estudantes com deficiência na universidade, este capítulo se concentra na apresentação e análise das informações oferecidas pelos participantes durante a entrevista semiestruturada. Em especial, serão abordadas as que versam sobre práticas inclusivas no cotidiano das universidades, e como estas se aproximam das necessidades educacionais de cada entrevistado. Aqui expomos as experiências dos oito participantes da pesquisa, cinco deles brasileiros, vinculados à única universidade pública do Brasil que foi objeto da pesquisa, e três portugueses, vinculados às universidades portuguesas investigadas.

$\mathrm{Na}$ análise, elencamos alguns significados que puderam ser depreendidos das enunciações de dois ou mais entrevistados. São aspectos da relação sujeito-outro envolvendo os estudantes com deficiência no contexto universitário - professores, colegas de turma, recursos disponíveis no sistema de apoio — que revelam experiências positivas, contradições, impasses e desafios para a inclusão no ensino superior. Foi possível destacar vários significados relacionados à experiência acadêmica e, para fins de exposição, agrupamos os temas em categorias. São elas: as relações com os professores e com colegas de turma, o papel dos serviços de apoio, a acessibilidade nos espaços da universidade e as sugestões para a qualificação das práticas inclusivas na universidade.

\subsection{A vivência com os professores: Impasses, preconceitos e desafios}

Nas entrevistas com os estudantes, foram feitas perguntas sobre aproveitamento nos estudos, dificuldades, aspectos positivos da experiência acadêmica, desafios vislumbrados e sugestões para a mudança das realidades institucionais. Respondendo aos questionamentos, os 
estudantes expuseram uma série de significados interdependentes do vínculo que a vivência acadêmica permite desenvolver com os professores. De forma geral, as narrativas remetem a dificuldades e desafios, mas também a apoio e incentivo. Seguimos expondo um relato que nos chamou atenção.

No semestre passado, tive uma professora que eu fiquei muito indignada com ela. Porque a gente... segunda e quarta, a aula dela era no [nome do prédio da universidade] e, na sexta, era no subsolo, porque era aula de laboratório. Só que a atividade que a gente fazia do laboratório era mexer no computador, que era olhar experimentos, nada que tivesse um equipamento que a gente fosse usar e manusear... Aí a gente conversou com a professora, argumentamos que não fazia sentido, os alunos da turma mesmo falavam que podiam trazer o computador.

Mas aí simplesmente a professora não quis. Ela falou que não, que não, que tinha que ser no laboratório, que não dava para mudar, e aí eu conversei com ela. Falei: "professora, a própria mestranda falou que não tem problema de mudar". E ela falou: "não, mas as atividades que vocês fazem lá, o link só abre nos computadores lá de baixo, a internet da universidade é ruim".

Sempre tinha uma justificativa muito nada a ver. E aí até um dia que ela virou para mim e falou na sala, no final da aula, tinha algumas pessoas ainda na sala, e ela olhou para mim e falou: "olha! A [nome da universidade] é assim e nunca vai mudar! Vai ter uma hora que você vai ter quer desistir!" Ela falou desse jeito! (Emília, estudante brasileira).

O excerto da entrevista reporta situações que comprometem o desenvolvimento de práticas inclusivas na universidade. A participante, que faz uso de cadeira de rodas, na situação de frequentar aulas no bloco de salas no subsolo e sem o recurso de elevadores ou rampas, via-se diante de uma dificuldade significativa para assistir as aulas. Com a negativa da professora em mudar de sala e a atitude de preconceito manifestada não havia alternativa para solucionar a questão. A primeira refere-se à adequação do espaço físico, e a segunda, à reificação dos valores institucionais relacionados à meritocracia, que causa preconceito e discriminação das pessoas com deficiência no ensino superior, em especial quando a fonte de preconceito são os professores. Como vemos na enunciação da estudante, a relação entre professor e alunos precisa ser foco de atenção. Reconhecemos que, para que a inclusão se 
efetive, são indispensáveis adequações e disponibilização de recursos. Entretanto, as questões que se ligam à esfera atitudinal da inclusão também merecem destaque e intervenção.

O professor é um agente importante na inclusão, pois está em contato direto com o estudante, mediando os processos de ensino-aprendizagem. Entretanto, se o docente nega ao estudante com deficiência condições para a realização das atividades acadêmicas, está contribuindo para a face perversa da inclusão. Não foi negado a esses estudantes o direito de acesso ao sistema de ensino, mas a precariedade, a menos-valia e a segregação que permeiam o contexto educacional não permitem uma inclusão efetiva (Leme, 2015). A inclusão requer o compromisso assumido por todos com a promoção de meios que permitam ao aluno a inserção em condições justas. Com isso, é papel do professor atender a todos os alunos em suas peculiaridades, oportunizando condições de desenvolvimento.

Michels e Dellacave (2005) apontam que é preciso assumir que a deficiência existe, caso contrário, incorre-se em preconceito e descaso. O empenho, sobretudo do professor, em flexibilizar e adaptar os recursos e meios para favorecer a inserção de todos os estudantes, entre eles os que têm deficiência, é essencial para a inclusão. O relato a seguir, feito por um estudante com transtorno de déficit de atenção, expõe estratégias do professor para promover a autonomia do estudante com deficiência.

Os professores ajudam, dão um prazo a mais. Eu peço um prazo a mais para ler e tudo mais. Eu peço também para me ajudar, eu procuro para ver se eles me explicam a teoria. Aí eles me explicam direitinho. Correr atrás, né. Isso que a maioria dos professores do meu curso me ajuda. Até agora eu peguei todos bons, menos um. De [área do conhecimento], era mestrando e não queria aceitar, disse que déficit de atenção não existe. (Pedro, estudante brasileiro).

O trecho recortado da entrevista do estudante expõe dois temas que julgamos relevantes. Por um lado, a disposição de professores em considerar os diferentes pontos de partida dos estudantes e apoiá-los na realização das atividades acadêmicas representa uma 
atitude inclusiva, que já se faz presente no cotidiano da universidade. Entretanto, essas são atitudes individuais, iniciativas próprias dos professores, desligadas de uma cultura ampla de inclusão. Isso faz com que uns se disponibilizem a realizar mediações que contornem as dificuldades dos alunos, enquanto outros, ao negar a existência do transtorno, negam também qualquer possibilidade de adaptação. Em decorrência disso, os estudantes enfrentam situações que acabam diminuindo as oportunidades de participação nas atividades acadêmicas.

Outro tema da enunciação do participante refere-se a atitudes questionáveis quanto à inclusão, advindas de estudantes de pós-graduação que atuam como docentes supervisionados ou monitores de ensino de graduação. Com base no projeto pedagógico da universidade, a articulação entre a pós-graduação e a graduação é estimulada, constituindo uma obrigatoriedade regimental a realização do estágio de docência na graduação durante o mestrado. Cremos que a inserção dos estudantes no contexto universitário, a partir de uma perspectiva docente (ou de monitoria), pode se converter em excelente oportunidade para a formação inclusiva dos mestres. Discutir a inclusão nessa etapa da formação profissional e acadêmica contribui com a criação de perfis de atuação docente imbuídos de uma maior compreensão sobre a temática da inclusão e, com isso, menos propensa a atitudes preconceituosas e discriminatórias.

O relato de outra estudante que tem deficiência visual suscita nova questão sobre as experiências com professores na universidade:

Os professores às vezes não entendiam por que eu precisava usar o computador nas frequências [atividades], mas com o tempo eles se acostumavam. E outra coisa que percebo [é] que os professores às vezes preparam as aulas muito próximo [ao dia da aula] e trazem fichas e aí esquecem da gente. E dizem: "esqueci de dizer que precisava digitalizar isso". E normalmente você tem que ficar sem fazer ou se juntar a um colega, e eles não conseguem evitar. Os professores acabam por preparar muito em cima o que consideram que é importante para a aula e não tem digital, só tem no papel, e por isso acabam por não conseguir adaptar. Mas muitos perguntam como 
fazer, como realizar as atividades, e aí eles se acostumam com a gente (Rita, estudante portuguesa).

Na fala de Rita são apresentadas dificuldades de acesso aos materiais utilizados pelos professores em sala, que em muitas ocasiões não são disponibilizados aos estudantes com deficiência. No caso, a indisponibilidade do material se dá pelo esquecimento do professor. A entrevistada tem a percepção de que o planejamento de aulas não é feito com a devida antecedência, de modo que não se dispõe de tempo hábil para o acesso prévio dos estudantes ao conteúdo. O fato acarreta dificuldades na realização de tarefas e acompanhamento das aulas, em especial no caso dos estudantes com deficiências sensoriais (cegueira e surdez) e transtornos (dislexia e espectro autista). Hoje há variados recursos de informática que possibilitam a digitalização de materiais, convertendo os arquivos textuais em arquivos de áudio, ferramenta preciosa para as aprendizagens na presença de deficiência visual. Um estudante com deficiência visual exemplifica outro recurso:

eu já filmo algumas aulas, mas alguns professores não deixam, mesmo que eu diga que eu não vou compartilhar, [que] eu só vou ver em casa depois, porque eu não estou vendo o quadro. Já teve caso de professores não deixarem eu filmar as aulas, porque eles não gostam. Apesar de ser raros, a maioria não se importa. Então normalmente eu filmo as aulas, quando têm slides eu peço os professores para eles me passarem os slides antes, para eu estudar para a aula. Então, até hoje só teve uma professora que não me passou os slides, apesar de eu dizer que eu não conseguia acompanhar a aula e copiar os slides, porque, no caso, a sala teria que ser escura, senão não dá para eu copiar. E eu disse para ela e ela disse que não, que não ia me dar porque não queria, e aí pronto (Maria, estudante brasileira).

A estudante se refere à estratégia de filmar as aulas com o celular e, dessa forma, poder voltar a ouvi-las, ativando outros recursos de memória, compensatórios à ausência da informação visual. Também enfatiza o valor pedagógico do acesso prévio aos slides apresentados a cada aula, pois, convertidos em arquivo do tipo PDF, podem ser "lidos" por aplicativos de conversão em áudio. Nota-se que o empenho em ultrapassar dificuldades e em 
beneficiar-se de recursos tecnológicos para favorecer as aprendizagens parece não ser valorizado pelos professores:

[...] não passar os slides para eu estudar, porque assim o objetivo dos slides, de não passar, era que a gente fosse forçado a copiar, mas eu não conseguia copiar. E eu queria copiar, mas não dá para copiar. Então, eu disse: "você poderia, por favor, passar os slides? Tudo bem não poder passar para a turma, mas eu não vou passar, eu quero ler e vou copiar em casa". Mas aí não, porque seria tratar diferente. "Se não posso mandar para ninguém, também não posso mandar para você." (Maria, estudante brasileira).

A recusa do professor em permitir o uso de recursos para a compensação (Vygotsky, 1983) e em disponibilizar o material ao estudante fundamenta-se quer na autoria (material autoral do professor, que não quer vê-lo copiado para os alunos), quer na igualdade de direitos (evitar tratamento diferenciado para os que têm deficiência). Em ambos os episódios, os professores parecem desconhecer tanto os princípios da educação inclusiva como seus fundamentos legais, que garantem ao estudante com deficiência tratamento diferenciado, com adaptações metodológicas e curriculares, que se ajustem a seu funcionamento perceptivo, motor ou cognitivo. Cremos que, com tais atitudes, o estudante se vê impossibilitado de exercer adequadamente seu direito à formação.

Se o professor não se sensibiliza às necessidades do aluno, a fim de que este possa executar regularmente as atividades de vida acadêmica, então ainda temos que avançar na discussão sobre o papel do professor na inclusão. A atuação do professor tem grande importância para a efetivação de práticas inclusivas no contexto universitário, e a negativa ou ausência de atitudes com essa finalidade prejudicam o desenvolvimento dos estudantes. Acrescentamos relatos da insensibilidade de docentes do ensino superior — a nosso ver, um reflexo do poder que caracteriza as relações interpessoais em contextos meritocráticos, como as universidades: 
neste período eu tive que trancar uma matéria porque a professora não quis mudar de sala. Eu já tive duas matérias em que os professores preferiram mudar de sala para que eu tivesse condições de acompanhar, mas uma matéria eu tive de trancar porque a professora não quis. Mesmo expondo, fui também ao PPNE, mas não consegui. Olha, ela era uma professora muito difícil, sabe, ela é muito difícil, e aí eu preferi não entrar no embate, preferi isso, tranquei a matéria, fiz com outra [professora] depois e não fui prejudicado. (João, estudante brasileiro).

Depois, eu tenho direito de meia hora mais para fazer as provas, e os professores não querem dar a meia hora. Eu quase tenho que brigar com eles, segurar a prova e dizer que eu sou a [nome da estudante], que tenho direito, que tenho NEE. Sempre assim. Mas só poucos entendem. E aí me sinto incompreendida e descontextualizada, mas não culpo meus professores. Embora eles deviam procurar saber, eles precisavam de alguém que lhes dissesse, e não há. (Alice, estudante portuguesa).

Embora se encontrem, nas instituições de ensino superior investigadas, professores reconhecidos por adotarem práticas favorecedoras da inclusão dos estudantes, ao flexibilizarem recursos e condições para o desenvolvimento de atividades, os episódios predominantes envolvem professores descritos pelos estudantes como inflexíveis e resistentes - características compreendidas por eles como traços da subjetividade do professor. O que vemos é que, nas universidades, o docente assume a responsabilidade máxima pela oferta da formação, sendo dele o poder de estabelecer as regras na sala de aula, mesmo que em detrimento da ética e dos direitos humanos — no caso em análise, dos estudantes com deficiência.

Práticas orientadas de tal forma expõem um regime excludente e meritocrático que existe nas universidades, apresentando-se ora de forma velada, ora de forma explícita. Na fala dos estudantes, a força dos significados já constituídos mostra que o poder exercido pelo professor é tão naturalizado que o estudante extrai de sua compreensão a dimensão política, aceitando o estabelecido e submetendo-se a ele.

O desenvolvimento de estratégias que possam facilitar o acesso aos recursos de aprendizagem e desenvolvimento é essencial ao sucesso da escolarização dos sujeitos com 
deficiência (Dias, 2004). É na interação com o meio social, isto é, com o contexto universitário e suas práticas de formação, que os caminhos de desenvolvimento podem ser facilitados ou dificultados.

As práticas de inclusão, entendidas segundo uma perspectiva ética, se estabelecem nas relações com o outro e, ao longo da história, favorecem a colaboração, o diálogo, a valoração positiva, que resulta em aceitação (Valsiner, 2012). Entretanto, ainda não é consenso no espaço da universidade que a inclusão é um direito inalienável dos estudantes, alcançado pelos meios necessários ao êxito de todos em sua trajetória de formação. Assim, resta aos estudantes buscar outros mecanismos que lhes possibilitem solucionar e contornar as dificuldades. São exemplos o apoio de colegas de classe, a iniciativa de acessar materiais e recursos para acompanhar o desenvolvimento das aulas e, até mesmo, o trancamento da disciplina. A falta de comprometimento ético do professor com as questões ligadas à inclusão no cotidiano da universidade possibilita a manifestação do preconceito. A esse respeito, os participantes comentam: “[...] o preconceito dos professores. Porque acho que no fundo é um preconceito. Quando a gente não entende uma coisa e não quer saber dela, é um preconceito. E é esse o problema dos professores. O preconceito que eles têm com os alunos" (Alice, estudante portuguesa).

O preconceito passa a constituir uma barreira no cotidiano da universidade - mais do que uma concepção errônea, ele é resistente a qualquer evidência ou conhecimento que possam desconstruí-lo. (Goffman, 1988). Assim, atitudes de preconceito tendem a provocar exclusão e dificultam a superação de situações que delas decorrem (Skliar, 1999). Significados como o senso de incapacidade e a ausência de perspectivas são barreiras que vão se interpondo ao desenvolvimento de habilidades e ao funcionamento ativo do indivíduo (Mantoan, 2008). 
A relação com os professores, por vezes traduzida em eventos de inflexibilidade, é uma barreira enfrentada por todos os participantes da pesquisa, permitindo inferir que se trata de uma dificuldade frequente. Estudos na área indicam que grande parte das dificuldades de inclusão relatadas por estudantes universitários decorre do seu relacionamento com professores (Abreu, Antunes \& Almeida, 2012; Antunes \& Faria, 2013; Fernandes \& Almeida, 2007; Fernandes, Almeida \& Mourão, 2007). Dos responsáveis pelo trabalho cotidiano com os estudantes, espera-se o envolvimento no debate e a reflexão sobre o papel da inclusão no desenvolvimento pessoal e social dos sujeitos (Mantoan, 2008).

Percebemos que a cultura da inclusão está insuficientemente disseminada entre os professores. Conciliar as práticas inclusivas e a vocação meritocrática que orienta a atuação docente no ensino superior demanda iniciativas criativas e problematizadoras, que produzam diferença inclusive para a formação continuada de docentes e profissionais.

Entendemos que, na relação com os professores, identificados como uma alteridade importante na auto-organização dos sujeitos, há indicadores dos posicionamentos assumidos pelos estudantes universitários. Percebemos uma ambiguidade de significados que medeiam a relação de estudantes e professores. De um lado, são fornecidos retratos de apoio, adaptações e abertura; de outro, denúncia de atitudes preconceituosas, rígidas e dificultadoras dos processos de desenvolvimento.

\subsection{A relação com os colegas de turma: Experiência positiva com a alteridade}

O papel das interações no desenvolvimento humano, como destacado por Vygotsky (1995), tem função preponderante. Nesse sentido, os participantes deste estudo ressaltam que a relação com os colegas de classe facilita a experiência acadêmica. Para eles, os colegas 
constituem uma rede relevante na obtenção de resultados satisfatórios e na construção de suporte ao enfrentamento dos desafios.

[...] os alunos também são muito unidos. No segundo semestre, eu peguei uma disciplina obrigatória, só que eles colocaram a turma no subsolo. E foi bem na época que só tinha um elevador funcionando, e ele não tinha luz... Então a gente só tinha esse elevador sem luz.... Aí, quando precisava descer, os próprios alunos ajudavam a gente a descer. (Emília, estudante brasileira).

E os colegas sempre ajudam muito, eu tenho um grupo de colegas que me faz acreditar que pelo menos eles estão ali ao meu lado, e vão tentar nos ajudar. Às vezes me ajudam, quando não tem materiais, ou que estão com problemas na digitalização, eles me ajudam a entender o que está ali nos materiais e depois também no grupo, ao trabalhar todos juntos, facilita-me muitas coisas, acaba por estarmos sempre juntos, nas aulas e fora das aulas. E quando tem um trabalho é mais fácil, porque eles já sabem como funciona, e isso a mim é mais fácil. Eles são muito importantes. (Rita, estudante portuguesa).

O papel de destaque desempenhado pelos colegas de classe remete-nos à importância da alteridade como contribuição positiva ao desenvolvimento das atividades cotidianas na vida acadêmica. Diferentemente das relações com os professores, que se mostram assimétricas e atravessadas por significados de poder, as relações entre estudantes têm por marca a simetria e a horizontalidade, levando a trocas mais autênticas e possibilitadoras de desenvolvimento e superação de dificuldades. A atenção dos colegas torna-se recurso promotor de desenvolvimento, pois possibilita ao estudante com deficiência desempenhar atividades de forma regular e confiante. Efetivamente, o apoio dos colegas é favorecedor do sentimento de estar incluído, pois deles advém grande parte do suporte que os estudantes veem como fundamental para sua permanência na universidade.

Eu tenho uma rede de amigos muito boa, eles me ajudam muito. Então, acho que não vou procurar ajuda especializada de um profissional, mas eu vou "perturbando mais os amigos" com isso. (Maria, estudante brasileira).

Agora mesmo, numa disciplina que estou fazendo, no primeiro dia de aula, um colega... chegou e disse: "vou te ajudar, independente de qualquer coisa..." Aí ele falou comigo: "estou aí à disposição, se precisar de ajuda pode contar comigo". (João, estudante brasileiro). 
Aliás, a nível de colegas, eu sempre tive muita sorte, colegas de turma fantásticas que me disponibilizaram apontamentos, livros, tudo para melhorar o meu desempenho. Portanto, pessoas impecáveis [...]. E quando chega a avaliação, eles me ajudam. E quando nós começamos o ano, eu aviso nos trabalhos de grupo. Eu aviso que sou disléxica, que faço trabalho em grupo com eles com muito gosto, mas se não quiserem trabalhar comigo, entendo, e não tem problema em fazer sozinha. Mas eles sempre me inseriram, nunca fiquei sozinha [...]. Tive imensa sorte com meus colegas de turma. Posso dizer que a maior ajuda vem deles, mesmo. (Alice, estudante portuguesa).

Os trechos acima são histórias de relação positiva com a alteridade, que acaba por atuar, em alguns casos, como parte nos processos de compensação aos estudantes com deficiência (Vygotsky, 1989). Dessa experiência, podemos inferir como os sistemas sociais têm importância no desenvolvimento do sujeito, canalizando trajetórias e criando possibilidades de futuro. No processo de desenvolvimento, os outros são importantes, uma vez que é na interação que ocorre a construção e revisão de significados, os conflitos e a tomada de decisão (Rey, 2005; Valsiner, 2012; Vygotsky, 1989).

Nas vivências relatadas pelos estudantes, os ganhos que se produzem quando há cooperação e companheirismo recaem sobre todos. O estudante com deficiência consegue, dada a mediação do outro, experimentar condições e acessar recursos para bem exercer seu ofício. E o estudante que se dispõe a apoiar os colegas em situação de deficiência também se beneficia e se desenvolve no processo de mediação. Descobrir novas formas de lidar com as diferenças, com o outro e com os saberes que se está partilhando promove desenvolvimento.

\subsection{O papel dos serviços institucionalizados de apoio}

Uma terceira categoria que emergiu das entrevistas com os estudantes foi o papel dos serviços institucionalizados de apoio à inclusão. As universidades aqui estudadas contam com tais serviços, criados com o intuito de promover ações de inclusão. As ações têm o objetivo de 
estabelecer uma política permanente de atenção às pessoas com deficiência, por meio da promoção da igualdade de oportunidades e da disponibilização de condições adequadas para o desenvolvimento na universidade. Ao serem perguntados sobre a atuação do serviço durante sua permanência na universidade, os estudantes informaram:

O [nome do serviço] me ajudou em mudança de sala, fazendo a comunicação entre a Reitoria e o departamento. Já peguei matérias em espaços longes da Universidade e eles conseguiram me ajudar a [realocar as aulas para] não mudar de prédio... São bem abertos, você quando precisa, vai lá, liga e conversa. (Emília, estudante brasileira).

No meu caso, nas situações em que eu precisei, procurei. O [nome do serviço] me ofereceu um monitor para me ajudar. Eu precisei numa matéria e me ajudou com a disciplina [nome da disciplina], em que eu tinha acompanhamento semanal. Também consegui que me ajudassem em um tempo maior para realizar minhas avaliações e trabalhos. Também existe um acompanhamento de estudos, encaixando meus horários de estudo, minha organização. (Davi, estudante brasileiro).

Eles são bons a fazer o trabalho deles. Eles dão-nos ajudas quando nós precisamos. Eu precisei de ajuda na inscrição porque eu era especial. E foi só esse apoio até agora e eles me atenderam. (Marcelo, estudante português).

Nesse semestre foi a primeira vez que eu pedi. Eu tinha uma aula no [local da aula], depois do [ponto de referência localizado ao norte do campus, em uma das extremidades de um prédio com 696 metros de extensão], de meio-dia às duas. E tinha uma aula das duas às quatro aqui no [local da aula], na ponta do [mesmo ponto de referência, na extremidade Sul]. E não dava para eu vir. E aí eu até conseguia vir, mas, por causa da visão, ia demorar muito, chegar atrasada. Daí eles têm um motorista que pega você de uma aula e te deixa na outra. É só solicitar. (Maria, estudante brasileira).

As ações de apoio que os serviços estão aptos a realizar, na opinião dos estudantes, resolvem questões práticas: adequação da localização de salas, para facilitar o acesso e diminuir distâncias, e auxílio no deslocamento dentro do campus, no intervalo entre aulas. Destaca-se, ainda, a orientação aos professores para a ampliação/adequação do tempo de 
realização das atividades escolares e avaliações, bem como a disponibilização do programa denominado monitoria especial ${ }^{16}$.

Ao analisar as informações produzidas por meio das entrevistas, percebe-se que os serviços atuam no apoio à permanência do estudante na universidade. Os estudantes reconhecem o valor das iniciativas de mediação, que visam equacionar problemas e promover oportunidades. Ao mesmo tempo, identificam limites e desafios a serem enfrentados pelos programas de apoio pedagógico, no que se refere à sua autonomia perante a gestão central, à carência de profissionais especializados em inclusão, assim como ao limite de seu escopo de influência em relação aos professores:

Mas eu acho que é um grupo que ainda não tem muita força na [nome da universidade], porque dependem de autorização da Reitoria para atuar. (Emília, estudante brasileira).

Mas eu acho que precisava de um especialista, lá precisava de uma psicóloga, tinha uma, mas ela saiu. E eu acho que precisaria de uma psicóloga, especialista, para acompanhar pessoas como eu, seria mais adequado. Eu acho que ele [o serviço] poderia, para minha necessidade, ter um acompanhamento melhor, um profissional especializado, seria bom. (Davi, estudante brasileiro).

Dentro das possibilidades, eles tentam, dentro das limitações, eles fazem o que é possível. Mandam e-mail aos professores, mas em alguns problemas não há o que fazer. (Alice, estudante portuguesa).

Os estudantes apontam a necessidade de que os serviços possam atuar de um modo mais sistêmico e contínuo do que a atenção às questões pontuais, com o objetivo de prover o acompanhamento continuado e sistemático dos sujeitos até que estes alcancem maior autonomia e agência na trajetória acadêmica. Consideramos que a busca por igualdade de oportunidades e o foco na singularidade dos estudantes é condição necessária, mas não suficiente, para alcançar situações e práticas inclusivas.

\footnotetext{
16 A monitoria especial, um serviço disponibilizado pela universidade brasileira, é exercida por estudante matriculado em disciplina onde existam estudantes com necessidades especiais, que assume a responsabilidade de fornecer apoio tutorial a estes últimos, além de favorecer seu acesso ao material didático. O monitor especial recebe uma remuneração compatível com a do monitor de graduação.
} 
A universidade tem obtido avanços, como instância promotora de práticas inclusivas, a exemplo da criação de sistemas de apoio institucionalizados. Entretanto, tais avanços não são bastantes para neutralizar os elementos normatizantes e homogeneizadores que tendem a presidir os sistemas de signos dominantes em um contexto meritocrático, conservador e seletivo, como tendem a ser as instituições de ensino superior. Persistem, como aqui discutimos, atitudes de preconceito e menos-valia em relação aos estudantes.

Entendemos as iniciativas em curso como importantes no enfrentamento à estigmatização dos estudantes com deficiência. Mas reconhecemos, da mesma forma, que ainda há importantes desafios para tornar o espaço universitário amplamente democrático e capaz de incluir as diferenças e demandas de todos os estudantes (Sousa, Soares \& Evangelista, 2003).

O espaço da universidade tem fundamental importância para a formação de consciências inclusivas, cujas ações podem ter impacto em diferentes contextos sociais. Uma universidade inclusiva necessita lidar com um perfil muito diferenciado de demandas, negando categorizações atribuídas universalmente (Mantoan, 2008). Interessa-nos a construção de um ambiente educacional em que as ambiguidades, ambivalências e diferenças não mais sejam negadas e desvalorizadas (Mantoan, 2008; Valle \& Connor, 2014).

\subsection{A acessibilidade nos espaços da universidade}

Um aspecto destacado nas entrevistas dos estudantes são as dificuldades que decorrem da ausência ou inadequação de dispositivos de acessibilidade no espaço universitário. Fato interessante é que o tema foi mencionado por estudantes diretamente afetados por essa inadequação, mas também por aqueles que não demandam esses recursos: 
Assim, a gente chega, mas é difícil, porque é muito longe... Então eu tinha aula no primeiro horário em um lugar, aí no segundo horário tinha que ir para outro lugar, e aí acaba que a distância e até mesmo o piso é ruim. Porque tem alguns buracos. Aí você tem que tomar cuidado, e acho que é basicamente isso. Não só nos [nome dos blocos de salas de aula], acho que principalmente estes prédios em que a gente tem aula, mas a biblioteca mesmo. Ela tem aquele elevador na entrada, mas desde que eu entrei, há dois anos e meio, que está quebrado, e a rampa está assim, meio levantando, ela está quebrada. Então a acessibilidade é ruim, você tem que ter sempre ajuda, não dá, por exemplo, as rampas para ir para o restaurante têm buraco no meio da rampa. Que o piso é bem... não sei se chega a ser de pedrinhas, eu não sei, mas tem buracos, então é meio... não dá para ir sozinha.

Eu me senti constrangida uma vez que eu caí. Tinha um buraco aqui no [prédio de salas de aula] um pouquinho mais à frente, e eu não vi. Eu estava parada. O pessoal até falou: "você não estava andando rápido?" E não! Eu estava parada, conversando com um amigo que eu encontrei de ensino médio, me despedi dele e virei. No que eu virei, a minha roda da frente prendeu no buraco, e aí eu caí. E aí alguns alunos da [nome do curso] me ajudaram a subir. É ruim, entendeu? E aí todo mundo vê! Todo mundo perto. (Emília, estudante brasileira).

O relato da estudante sobre as precárias condições de acessibilidade no espaço da universidade exemplifica as dificuldades e barreiras impostas aos estudantes com deficiência física e/ou mobilidade reduzida. Uma das universidades investigadas, ademais, tem sua base física tombada pelo patrimônio histórico e cultural, razão pela qual muitas das adaptações têm de vencer a burocracia.

O cuidado com a acessibilidade, entendida como o livre e fácil acesso e ingresso aos espaços (Caiado, 2010), e as condições de mobilidade segura e ampla são ações inclusivas básicas. Como destaca Fischer (2014), normalmente as universidades disponibilizam os recursos de acesso e mobilidade aos espaços visitados com maior frequência pelos estudantes, restringindo assim deslocamentos e atividades. As dificuldades fazem com que os estudantes enfrentem desafios para chegar ao campus, ir de um espaço a outro e, ainda, sair da universidade em condições adequadas e seguras.

Há algumas coisas em termos de espaços físicos que poderiam ser melhoradas ou redefinidas, mas eu sei que nem sempre é fácil, porque fazer muitas mudanças no espaço físico nem sempre é possível. Alguns serviços estarem mais acessíveis, cantina, bar. (Rita, estudante portuguesa). 
Eu decoro os lugares. Faço um mapa deles, para conseguir ir lá de novo. Por isso eu acho ruim quando mudam as coisas de lugar sem avisar. Porque quando muda é como se eu nunca tivesse andado lá. Na biblioteca, eu até chego lá fácil, e lá dentro é mais escuro do que eu acho que deveria ser. Tem o piso tátil, aí dá para ir. E é legal quando as pessoas ficam no meio dele [risos com ironia]. Eu acho que as pessoas não entendem que só tem piso tátil porque as pessoas realmente precisam dele. Parece que é só uma coisa no chão e eles ficam no meio. E era legal se os alunos soubessem que ele existe porque tem outros alunos que não conseguem andar por outro lugar. Então, quando as pessoas não estão no meio do piso tátil, é bom, porque dá para ir por ele, porque, se elas estão, tenho que ir para outro lugar e procurar de novo lá na frente. (Maria, estudante brasileira).

A narrativa da entrevistada aponta que os estudantes universitários, em geral, carecem de informações básicas tanto sobre a função dos dispositivos de sinalização e dos equipamentos de acessibilidade como sobre a conduta em ambientes sociais onde há pessoas com deficiência. Dessa forma, comportamentos equivocados podem se converter, ainda que inadvertidamente, em mais uma barreira à plena inclusão das pessoas com deficiências.

Precisa de várias coisas. Para quem é cadeirante, para quem é cego. Eles precisam de mais ajuda que eu... O que me prejudica são os trabalhos e outras coisas mais no dia a dia. Mas para quem é cego e cadeirante, para eles as barreiras são mais difíceis. A questão de chegar. Eu mesmo não tenho problema de chegar à universidade, já eles têm limites. Por que os cadeirantes precisam de pistas de andar aqui dentro da universidade, principalmente em dia de chuva. [...] E os cegos precisam de guias, né? Então precisa melhorar muito. Nada pode parar. Tem sempre que melhorar para todo mundo. Não pode ficar se conformando com o que já tem. Tem sempre que avançar em várias coisas. (Pedro, estudante brasileiro).

Os trechos destacados remetem a questões relevantes para a acessibilidade dos espaços na universidade. De início, a estudante com deficiência visual apresenta os mecanismos que aciona para se deslocar nos espaços, na tentativa de ser autônoma: fazer mapas mentais das localidades, orientar-se pelo piso tátil. Entretanto, esses são comprometidos quando as pessoas fazem mudanças sem aviso ou ocupam o piso.

Fatos assim acabam por reduzir os deslocamentos dos estudantes e aumentar a necessidade de ajuda de terceiros em diversos momentos e atividades — ida ao restaurante 
universitário, à biblioteca, às aulas distribuídas em diferentes prédios, a eventos nos auditórios. Além de riscos à integridade física, essa dificuldade gera nos estudantes constrangimentos que alimentam significados relacionados à desvantagem, à diferença. Esta é percebida como negativa, impeditiva do exercício autônomo de atividades e de inserção nas práticas cotidianas, comprometendo, por isso o sentimento de cidadania.

\subsection{Qualificação das práticas inclusivas na universidade: A voz dos estudantes}

Os estudantes entrevistados foram convidados também a refletir sobre o futuro e apresentar os principais desafios a serem enfrentados pela universidade na construção de um modelo de atuação mais inclusivo:

eu acho que a inclusão no ensino superior, na escola e no mercado de trabalho devia ser aquilo que nós encontramos nos livros, e diz que a inclusão é basicamente a igualdade para todos e que todos terem as mesmas oportunidades, e se calhar, isso devia passar mais à prática. Não só no ensino superior, mas nas escolas e no mercado de trabalho. E no ensino superior isso não acontece. E aqui na universidade ele vai se enrascar sozinho, porque não tem o suporte da professora do ensino especial, na universidade isso não existe. $\mathrm{O}$ aluno tem que resolver tudo sozinho, vai ser ele a procurar os professores e falar como é que funciona... temos que ser nós a explicar essas coisas e muitas vezes são pormenores que os professores não têm a noção de que nos podem causar um problema porque não conhecem. Deve-se dizer a todos: "você vai passar pela universidade, mas agora você que vai ter que fazer aquelas coisas que antes quem fazia era a professora do ensino especial". Aqui infelizmente eles são obrigados a aprender a viver e a explicar aos professores sozinhos as necessidades que têm. E precisam aprender. (Rita, estudante portuguesa).

A fala acima refere-se à desinformação, ou seja, aos bloqueios à circulação da informação sobre educação especial, inclusão, direitos e deveres da pessoa com deficiência, dos outros estudantes e dos próprios professores. Vemos a importância da informação em duas vertentes. Por um lado, a necessidade de orientar os estudantes com deficiência sobre a vida na universidade, em particular, sobre suas atividades acadêmicas (sistema de matrícula em 
créditos, avaliação, nota mínima exigida para aprovação etc.). Se adequadamente informados das rotinas e atividades a desempenharem na universidade, esses estudantes podem sentir-se mais seguros e confiantes - com expectativas mais positivas em relação à universidade e ao curso, e com estímulo ao desenvolvimento da sua autonomia.

Por outro lado, informar colegas e professores sobre as características e especificidades dos estudantes com deficiência é um importante mecanismo de inclusão, permitindo a discentes e docentes encontrar formas mais adequadas de trabalho, que tenham em conta a diversidade estudantil (Abreu \& Antunes, 2011; Fernandes \& Almeida, 2007). As relações construídas na presença de informações reais sobre demandas, possibilidades e limites tendem a ser mais seguras e produtivas, resultando em melhor aproveitamento da experiência acadêmica (Almeida, Antunes \& Faria, 2013; Bucuto, Almeida \& Araújo, 2014; Coulon, 2008; Dias \& Lopes de Oliveira, 2013).

Necessidades de adaptação do espaço da universidade são elencadas:

Olha! Eu acho que é colocar rampas. Porque o chão do [nome do prédio da universidade] não tem contraste, é só uma pedra, um bloco, eu enxergo não tanto as formas, mas os contrastes entre elas... Para quem tem problema de locomoção, eu acho bastante perigoso as coisas aqui na universidade. A iluminação precisa muito melhorar. Tudo para a gente ter mais segurança... Não tem luz. E eu acho que deviam pôr mais piso tátil em todos os lugares da universidade. Aqui no prédio já estão faltando algumas peças, porque as pessoas arrancam ou porque ele sai. Mas é um investimento importante. (Maria, estudante brasileira).

A sugestão da estudante destaca a necessidade de garantir mecanismos mínimos de acessibilidade, presentes em todo o espaço onde circulam os estudantes das duas universidades. Espaços acessíveis e seguros eliminam barreiras importantes ao deslocamento dos estudantes, promovendo condições mais autônomas de participação nas atividades da rotina acadêmica. 
Outro destaque nas enunciações é necessidade de formação dos professores para a

inclusão:

cada departamento trazer para os professores estas necessidades dos alunos e isso ficar assim, internalizado nos professores, a questão dos alunos. Embora notemos que eles têm assim um tratamento, um jeito especial com a gente, mas nem todos têm esta percepção, entendeu? Porque é necessário, sabe, é necessário, mesmo, a gente precisa. E que ele [professor] saiba, por exemplo, que ele tem que falar alto, mesmo, porque tem alguém que não ouve, entendeu? É isso que falta, eu acho que tem que ser assim para que todos os professores tenham o mesmo conhecimento e a mesma forma de agir. (João, estudante brasileiro).

Sobretudo, eu acho que há muito desconhecimento ainda, e se calhar passaria muito por, primeiro, os professores saberem... É difícil falar com um professor sobre uma necessidade especial e de repente o professor dizer que não acredita nisso. E pode ser o aluno a falar com o professor e ficar constrangido. Mas os professores deviam no geral, na sua formação de base, ter uma unidade curricular ou qualquer coisa que pudesse lhes dar uma formação para que compreendessem que os alunos que têm, por exemplo, deficiência visual, seja ela baixa visão ou cegueira, podem trabalhar dessa forma e assim eles teriam uma noção. Porque muitas vezes as perguntas que nos fazem são porque não conhecem, nota-se que é por desconhecimento. (Alice, estudante portuguesa).

E quanto aos professores, na verdade eu acho que os professores deveriam receber um curso rápido... Mas seria bom se eles pudessem fazer um curso de preparação. Por exemplo, assim: "olha, seu aluno tem deficiência visual, por exemplo, então quando seu aluno pergunta uma coisa muito óbvia, não é porque ele não entende, é porque ele não está vendo. Procura mostrar mais. Quando você escreve no quadro, você deve falar o que está escrevendo". (Maria, estudante brasileira).

De forma geral, os estudantes reportam dificuldades e impasses na relação com os professores em situações cotidianas que demandam iniciativas como atenção às especificidades, adaptações curriculares e de materiais. Daí a necessidade de ações de formação que qualifiquem os docentes para práticas mais inclusivas. Como afirmamos, o professor desempenha um papel importante na consecução das práticas inclusivas e, para responder às demandas, a formação constitui fator preponderante ${ }^{17}$.

\footnotetext{
${ }^{17}$ Nos próximos capítulos, aprofundaremos a reflexão sobre o papel do professor na promoção da inclusão no ensino superior.
} 
Hoje a sociedade facilita mais para as pessoas que não têm deficiência do que para as pessoas que têm. Tem que avançar mais ainda para quem é deficiente. Então tem que pensar, olhar mais para o lado dos deficientes, para lá na frente ter uma igualdade de oportunidade para os dois. Isso facilitaria muito a igualdade para todos. E isso é bom. (Pedro, estudante brasileiro).

A fala de Pedro reporta a uma questão importante no processo de inclusão. Consideramos fundamental que o estudante universitário com deficiência seja respeitado, como pessoa com potencialidade, cuja posição acadêmica foi conquistada por meio do esforço pessoal, do mesmo modo como os demais estudantes (Zanella, Lessa \& La Ros, 2002). Tal reconhecimento sobrepõe-se aos impedimentos, obstruindo sua conversão em barreira ao sucesso escolar. Além disso, assim como a promoção de atitudes sociais favoráveis à inclusão, o reconhecimento apoia a permanência dos jovens estudantes na universidade. As atitudes favoráveis organizam ou reorganizam crenças e cognições sobre diferenças, direcionando para a aceitação e criando espaços para a promoção de atitudes inclusivas (Xavier, 2012).

Para que a universidade possa ampliar e qualificar efetivamente a inclusão, são necessários investimentos. É preciso praticar ações para intensificar a atuação dos serviços de apoio, que envolvam a formação de professores e demais servidores, e tornar acessíveis os bens, as atividades e os espaços do campus. 


\section{A PERSPECTIVA IDIOGRÁFICA: NARRATIVAS DAS TRAJETÓRIAS ESTUDANTIS ${ }^{18}$}

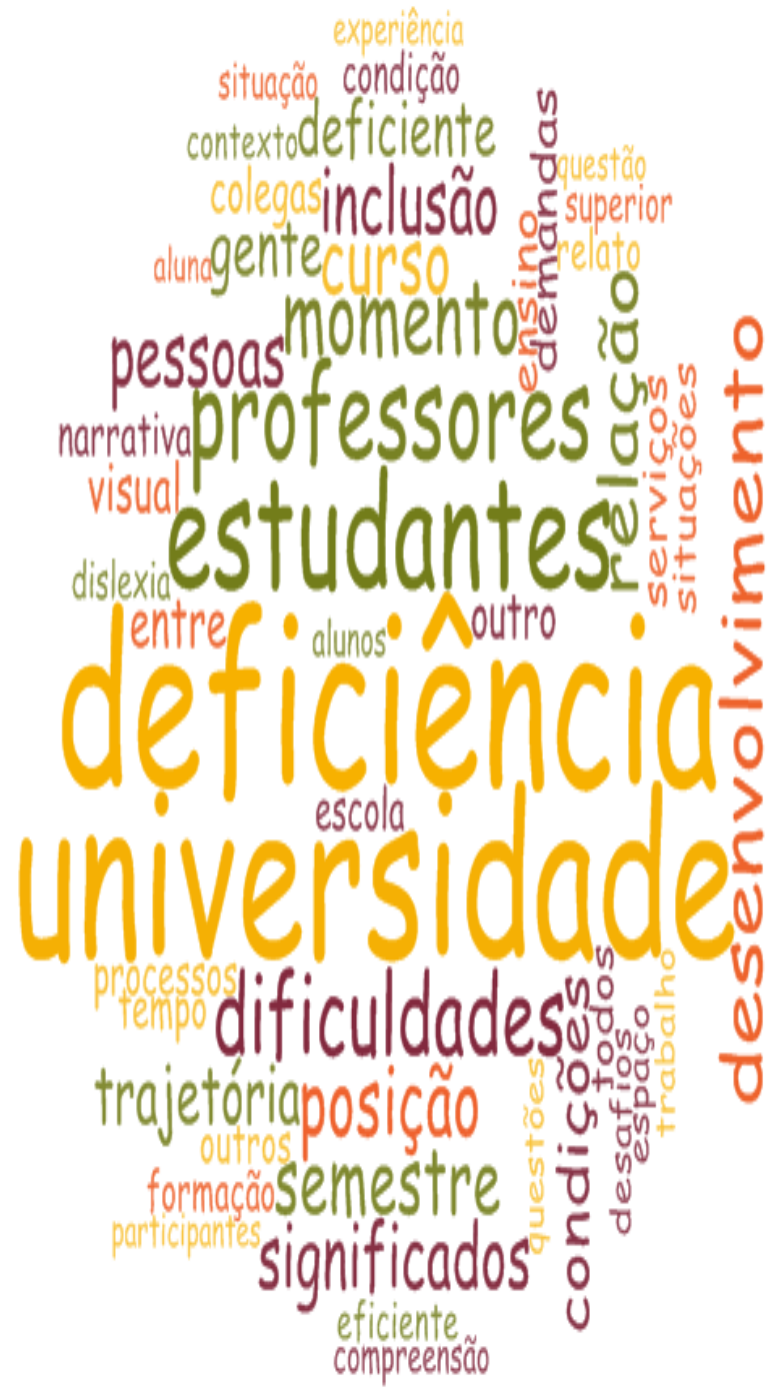

${ }^{18}$ Nuvem de palavras elaborada com o uso do software NVivo 10, em que considerando as narrativas de entrevista, foram selecionadas as cinquenta palavras com maior ocorrência. Ao centro e em maior tamanho as palavras mais frequentes. 


\subsection{João: Os desafios de um guerreiro ${ }^{19}$}

João é um senhor de 61 anos, casado, pai de três filhos, servidor público federal, que possui uma surdez severa (porém parcial) e bilateral, resultante de duas intervenções cirúrgicas que realizou para a retirada de tumores nos ouvidos em um intervalo de sete anos a primeira intervenção foi em 1988, e a segunda, em 1995. João teve uma trajetória escolar marcada por dificuldades. A infância foi pobre. Órfão de pai, ele vivia com a mãe e cinco irmãs. Estudou dos 7 aos 14 anos, sofreu reprovações escolares nesse período, e, quando sua mãe perdeu a capacidade laboral, começou a trabalhar para ajudar no sustento da família em atividades braçais. Por conta do trabalho, chegava à escola cansado e dormia nas aulas. Perdeu o estímulo e abandonou os estudos. Já adulto, casou-se, teve filhos, e o trabalho para cuidar da família não lhe permitiu retornar à escola.

Entretanto, ele alimentava o desejo de retomar os estudos, o que só conseguiu fazer aos 50 anos. João acessou o ensino supletivo, estudou sozinho, fez os testes (provão) e conseguiu concluir o ensino médio aos 55 anos. Em seguida, iniciou seu percurso rumo ao ensino superior. Ele comprava DVDs de vídeo-aulas em uma feira da cidade, estudava só após o horário de trabalho e, na segunda tentativa, conseguiu ser aprovado no exame vestibular da universidade.

João conta que sua doença resultou numa perda auditiva bilateral classificada como severa. Em um ouvido, ele teve perda de 70 decibéis, resultante da primeira intervenção cirúrgica, e de 80 decibéis, por conta da segunda intervenção. Ele afirma que a segunda cirurgia, em que a perda auditiva foi mais acentuada, gerou a deficiência. João teve dificuldades em lidar com a nova configuração, mas com o tempo se acostumou a ela.

\footnotetext{
${ }^{19}$ Os nomes dos participantes são fictícios.
} 
Desenvolveu a capacidade de fazer leitura labial e adia a colocação de próteses auditivas, denominando-se teimoso. Ele relata que algumas pessoas admiram suas capacidades de fazer leitura labial e falar baixo, enquanto outras zombam de sua condição, algo que ele considera normal.

O acesso de João à universidade se deu no primeiro semestre de 2010, para um curso na área social. ${ }^{20}$ No momento da entrevista para esta pesquisa, ele se mostrou atencioso e tranquilo. Com base em nossa interação, infiro que João é uma pessoa esforçada, perseverante e humilde. Identifica-se como guerreiro (superou muitas dificuldades), teimoso (não faz uso de prótese auditiva) e vitorioso (realizou conquistas pessoais, familiares e profissionais). Tem gestos suaves — fala gesticulando, às vezes apoia a cabeça entre as mãos —, sua voz é baixa e tranquila, fazendo algumas pausas, momentos em que parece buscar nas memórias os fatos e a melhor forma de narrá-los. Parece emocionado ao falar do curso superior e entusiasmado com a formatura, que se aproxima (está cursando o último ano).

Sua participação na pesquisa ocorreu de forma voluntária, mediada pelo sistema de apoio à inclusão da universidade. O contato inicial foi feito pela pesquisadora, por e-mail, ao qual ele respondeu se prontificando a participar da pesquisa. Questionado, por e-mail, se era usuário da LIBRAS, para o caso de necessitar de um intérprete, João disse que não, pois fazia leitura labial e tinha resíduo de audição. Ele informou um número de telefone residencial para que os contatos fossem feitos para a marcação da entrevista. Foram feitas duas ligações para marcar dia e horário de encontrá-lo, e o atendimento foi feito por uma senhora, que afirmou ser a esposa dele. O contato inicial por intermédio da esposa possivelmente se justificava pela

\footnotetext{
${ }^{20}$ Por questões éticas, os cursos dos estudantes são designados de forma genérica, mencionando apenas as grandes áreas: social no presente caso, tecnologia no próximo (Maria) e licenciatura no caso final (Alice).
} 
dificuldade em ouvir. A entrevista foi marcada para o espaço da universidade, em horário após a jornada de trabalho e antes da primeira aula de João, que é estudante do turno noturno.

Quando cheguei ao local combinado, João já estava presente, sentado em frente à sala, em um banco no corredor. Ele perguntou se eu era a pesquisadora, ao que confirmei, e me convidou a adentrar a sala, que estava desocupada. Após as apresentações pessoais e a formalização do convite, com a exposição dos objetivos da pesquisa e a leitura do termo de consentimento livre e esclarecido (TCLE), João confirmou seu interesse em conceder a entrevista, pedindo apenas para nos sentarmos a pouca distância e de frente um ao outro, dada sua dificuldade em ouvir. A partir daí, iniciamos a conversa sobre a trajetória de vida e estudantil dele.

A entrevista teve a duração aproximada de cinquenta minutos, e abordou todos os temas do roteiro. Ele que fez sua narrativa, destacando livremente os aspectos que julgava mais relevantes. As intervenções da pesquisadora foram feitas apenas em determinados momentos, seja para inserir questões ou temas novos à conversa, seja para pedir que ele complementasse informações. De forma geral, o relato de João entrelaçou sua trajetória pessoal e estudantil, abordando questões diversas que estiveram relacionadas às suas experiências.

Um ano e dois meses após a entrevista, João foi contatado novamente. Por e-mail, foilhe feito o convite para escrever uma carta, em que relatasse livremente acontecimentos relevantes em sua vida no período desde a entrevista. Após alguns dias e algumas mensagens de reforço ao pedido, João enviou a carta por e-mail. 


\subsubsection{A relevância do caso}

Escolher o caso de João para compor, entre o quadro de participantes, o estudo mais aprofundado tem uma justificativa. $\mathrm{O}$ caso nos oferece a oportunidade de analisar os significados em torno da deficiência e o desenvolvimento adulto em situações peculiares.

Primeiro, a ideia da deficiência que emerge na vida adulta, decorrente de uma novidade que altera de forma significativa a auto-organização do sujeito. Segundo, a compreensão do desenvolvimento que se dá mediado pela experiência universitária e se situa no período em que o sujeito se aproxima da velhice. E, ainda, a relação entre o estudante com deficiência e os serviços de apoio disponibilizados para a inclusão na universidade.

\subsubsection{A trajetória de João}

A apresentação da trajetória de vida e educacional de João se baseia em sua narrativa, evocada em situação de entrevista semiestruturada, e também na carta escrita por ele à pesquisadora um ano após a entrevista. Assim, começamos por expor a análise da entrevista e, ao final, abordamos o conteúdo da carta. Analisamos, com base nas enunciações do sujeito, os processos de significação ao se constituir como estudante com deficiência auditiva no complexo contexto de desenvolvimento que é a universidade. Voltamos nossa interpretação para a compreensão dos processos, dos mecanismos e das estratégias que o sujeito usa para lidar com a realidade e suas contradições, de forma dinâmica e dialógica.

Na narrativa de João, nossa abordagem elenca os significados em torno da experiência estudantil e os coloca em ambivalência, para identificar aqueles que apoiam a sua capacidade

de lidar com as possibilidades e incertezas do futuro (Abbey \& Valsiner, 2005). As 
ambivalências vão se tensionando no presente, associando-se a experiências passadas, e assim resultam em significados que apoiam respostas aos desafios cotidianos, bem como permitem antecipações de futuro.

O desenvolvimento se baseia em momentos de transição nos quais o sujeito busca se reorganizar e superar as incertezas tensionadas nas ambivalências (Abbey \& Valsiner, 2005). Os processos de desenvolvimento são fenômenos dinâmicos e dialógicos, que tensionam a relação entre certeza e incerteza - no nosso enfoque, tensionam a relação a deficiência e os desafios colocados pela experiência de cursar o ensino superior. Passamos, a seguir, a analisar as ambivalências por nós elencadas na história de João.

\subsubsection{A tensão entre os significados eu-estudante e eu-trabalhador}

Minha trajetória escolar, comecei aos 7 anos, na escola, e levei... tive algumas reprovações durante minha vida escolar, e isso acabou por me levar a abandonar a escola... E aí, na minha juventude, mesmo, eu acabei não conseguindo voltar a estudar, porque outras influências me levaram a não estar no banco da escola, e aí depois me casei... e aí pronto, aí mesmo que a gente perde, aí não dava mesmo para estudar, não tinha condições. Uma das causas que me levaram a abandonar os estudos foi que, aos 14 anos, eu tive que trabalhar para ajudar no sustento da família. Minha mãe não podia mais trabalhar, era filho órfão, cinco irmãs, e era trabalho braçal mesmo, e no primeiro ano que trabalhei e estudei eu já não consegui.

O relato de João nos reporta à sua subjetividade no contexto educacional e social no qual estava inserido. Percebemos significados que se organizam em torno das ambivalências eu-estudante e eu-trabalhador, designados nas análises a seguir, respectivamente, como $(\mathrm{e}-\mathrm{E}) \mathrm{e}(\mathrm{t}-\mathrm{T}) .{ }^{21}$ São os significados em torno do eu-estudante e eu-

\footnotetext{
${ }^{21}$ A designação das posições de estudante e trabalhador com o uso da notação $(\mathrm{e}-\mathrm{E})$ e $(\mathrm{t}-\mathrm{T})$ propõe marcar a força que cada posicionamento do Eu tem na organização subjetiva de João, a cada momento destacado por ele na entrevista. A letra minúscula marca o enfraquecimento do posicionamento, enquanto a maiúscula marca o fortalecimento.
} 
trabalhador que elencamos, no primeiro momento do relato, como relevantes para a análise, pois, tendo em vista a realidade e as condições experenciadas, constituir-se como estudante e trabalhador representou uma tensão dialógica, com caminhos distintos na vida de João.

Ele fala de sua entrada na escola aos 7 anos e emenda com suas dificuldades escolares, dando a compreender que os insucessos marcaram sua trajetória, na infância e adolescência, inclusive tendo vivenciado situações de reprovação escolar. Conta que sua família experimentou pobreza severa, que era órfão de pai, mas que, embora com dificuldades, até os 14 anos frequentou "o banco da escola". Na tensão eu-estudante e eu-trabalhador, apesar das dificuldades, o significado que se destaca nesse momento da narrativa refere-se à posição euestudante $(\mathrm{E}-\mathrm{t})$.

Na sequência, João relata que a mãe não podia mais trabalhar e, que com cinco irmãs, sua força de trabalho passou a ser essencial para o sustento da família. Como ele exercia serviço braçal durante o dia, passou a estudar à noite, mas chegava à escola cansado, não conseguindo obter aproveitamento. Afastou-se cada vez mais da motivação para prosseguir, até abandonar os estudos. O seu distanciamento da possibilidade de estudar se ampliou quando ele se casou e logo teve filhos, passando a focar no cuidado da família, uma condição em que permaneceu até cerca dos 50 anos, quando voltou a estudar. Nossa interpretação é que, nesse momento, a tensão se configura de forma diferente, prevalecendo a posição eu-trabalhador (e - T): “e eu vim pensar em estudar já depois dos 50 anos, quando eu comecei a visualizar esta possibilidade. Aí entrei no supletivo, estudava e fazia as provas, e consegui concluir com 55 anos".

João retomou seu interesse pela escola e fortaleceu a posição eu-estudante quando voltou a estudar, aos 50 anos. Ele deu continuidade à sua formação, num momento em que se considerava estável na vida (filhos criados e formados, emprego estável, casa própria). De 
início, estudava só, após o trabalho, e fez exames supletivos para obter a certificação do ensino médio, que concluiu aos 55 anos. A posição eu-estudante ganhou destaque, configurando-se como indicador semiótico em torno do qual João organiza sua vida conjuntamente com a posição eu-trabalhador, no nosso entendimento, equilibrando as posições em tensão. Como naquele momento João já se julgava realizado profissionalmente, a emergência da possibilidade de voltar aos estudos impulsionou a posição eu-estudante, que se fortaleceu também em sua trajetória $(\mathrm{E}-\mathrm{T})$ : “Eu me considero um guerreiro por ter saído de onde eu vim e ter chegado onde estou, tanto profissionalmente como em termos pessoais, mesmo! Me considero um vitorioso na vida!"”

João relaciona sua vida adulta às responsabilidades e aos posicionamentos por ele assumidos: o casamento, o nascimento dos filhos, os cuidados com a família. Seu relato aponta, ainda, para conquistas que ele considera importantes e que o transformaram em pessoa vitoriosa: um cargo importante e estável no serviço público; a remuneração advinda da ocupação laboral; a família, com os três filhos formados; e a casa própria.

\subsubsection{A tensão entre os significados eu-eficiente e eu-deficiente}

\footnotetext{
Ela [a deficiência] surgiu porque eu tive tumores. O primeiro tumor surgiu no ano de 1988, ano de nascimento de meu filho caçula, e aí eu tive que fazer a cirurgia. Porque o tumor aloja-se no osso e vai comendo o osso, tem que tirar. E para tirar tem que tirar junto os tímpanos, bigornas, martelos, e a gente acaba por adquirir a surdez. E aí em 1995 surgiu o outro, e eu tive que tirar também... cada procedimento cirúrgico é de uma forma. No último, eu perdi bem mais audição que no primeiro, daí surgiu a minha deficiência.
}

Nesse momento da narrativa, João contou sobre o surgimento da deficiência e como sua vida se reorganizou a partir daí. Emergiram, assim, posicionamentos que configuraram 
outras tensões, relacionadas às posições eu-eficiente e eu-deficiente. Essas posições impactaram sua subjetividade e, de algum modo, reordenaram a dinâmica dos processos vividos.

Ressalto que eu tinha ouvido de tuberculoso antigamente, eu ouvia muito, e uma prova que eu tive foi esta.

E aí eu consegui me acostumar com isso, e me acostumei tanto que as pessoas cobram de mim o fato de não usar aparelho, mas eu me acostumei tanto, inclusive a fazer leitura labial, me acostumei a focar muito nisso, que eu vou adiando a colocação do aparelho, sou teimoso!

João entende o ensurdecimento como "uma prova" pela qual passou, uma vez que, antes da deficiência, ele "tinha ouvido de tuberculoso", uma alusão à boa capacidade auditiva. João lembra ter vivenciado um período difícil diante do duplo diagnóstico, mas se acostumou ao novo modo de funcionamento sensorial, ao ponto de dispensar o uso de próteses. Percebemos aí o processo de ressignificação do vivido, quando, diante da nova configuração de si, ele passa a buscar meios de superar a ausência parcial da audição, com a adoção de mecanismos pessoais de adaptação e compensação, como a leitura labial e o foco (termo usado por João, compreendido por nós como o esforço para ouvir, dentro de suas possibilidades e limites). Os mecanismos compensatórios desenvolvidos por João são tão eficientes que o fazem adiar o uso de aparelho auditivo, embora tal recurso seja cobrado pelas pessoas (inferimos que ele se refere às pessoas mais próximas, com as quais convive), motivo pelo qual ele se declara "teimoso". A significação atribuída por João ao termo "teimoso" destaca um posicionamento ativo diante das limitações impostas pela condição de ouvir pouco. A tensão entre as posições eu-eficiente e eu-deficiente, no momento narrado, aparece em equilíbrio (E - D).Em seguida, a narrativa se organiza em torno de sua retomada dos estudos e das vivências nesse novo momento da vida. Considerando-se a ambivalência entre as posições 
eu-eficiente e eu-deficiente, identificamos nova reconfiguração na trajetória de João — como estudante universitário -, o que representa um marcador importante de seu desenvolvimento.

Aí foi quando eu comecei a tentar o vestibular, e na segunda vez eu consegui passar. Mas para conseguir passar eu tive que ir à feira do Paraguai, comprava os DVDs de aulas por matérias, levava para casa e depois do trabalho eu ia estudar.

Após a conclusão do ensino médio, movido pelo interesse de realizar um curso superior, João relata seu esforço para perseguir tal objetivo: menciona a preparação, que fez sozinho, e o recurso das aulas em vídeo, a que tinha acesso quando comprava DVDs na Feira do Paraguai. Sua persistência, que a nosso ver se relaciona diretamente à sua autoidentificação como "vitorioso", também é percebida no fato de que não passou no primeiro vestibular, e de que chegou a tentar acessar o sistema de cotas - em dado momento da narrativa, ele se define como negro, inclusive aludindo à remuneração inferior do trabalho da pessoa negra na sociedade); porém, não conseguiu vaga pelo sistema por não ter sido aprovado na etapa de entrevista.

Nesse trecho da narrativa de João, julgamos relevante destacar alguns aspectos relacionados ao acesso ao ensino superior por pessoas em situações peculiares - como aqueles que são mais velhos, trabalhadores, ou pessoas com deficiências. De início, a falta de programas públicos voltados ao reingresso escolar de pessoas adultas trabalhadoras. A maior parte do investimento concentra-se na alfabetização de adultos, permanecendo uma lacuna quanto aos anos finais e ao ensino médio, o que João contornou comprando videoaulas. Em virtude disso, a continuidade dos estudos fica a cargo da iniciativa e do esforço individual. A falta de material didático adaptado às pessoas com deficiências para a preparação para o 
vestibular é outra realidade pouco colaborativa à inclusão. Fatos assim explicam parte do insucesso de João no primeiro vestibular.

Outro ponto a problematizar refere-se ao sistema de cotas na Universidade de Brasília. O sistema em vigor contempla cotas sociais para estudantes de baixa renda e cotas raciais para negros, pardos e indígenas. ${ }^{22}$ A ausência de um sistema de acesso para pessoas com deficiências faz com que essa parcela de estudantes, que também representa uma minoria, fique invisibilizada nas ações inclusivas. Conduzimos a análise para as vivências de João no cotidiano de seu ofício de estudante:

Eu adoro meu curso, abriu minha cabeça, assim... sabe?! Eu me considero satisfeito com a [nome da Universidade]. Olha só, eu não sei se, porque era um sonho e eu estou aqui, e estou fazendo tudo para aprender, dentro do melhor e dando o melhor de mim...

Na universidade, no primeiro semestre nós fomos para uma sala em que, ao lado, tinha ensaio do coral e eu não conseguia ouvir de jeito nenhum. E a minha coordenadora e também professora me disse que tinha como conseguir o tutor, e aí ela fez o encaminhamento. Ela me indicou o PPNE, eu fui e consegui ter os tutores... Mas assim, neste período eu tive que trancar uma matéria porque a professora não quis mudar de sala. Eu já tive duas matérias em que os professores preferiram mudar de sala para que eu tivesse condições de acompanhar, mas uma matéria eu tive de trancar porque a professora não quis.

A aprovação para um curso superior na área social, pelo qual João tem muito entusiasmo, é descrita por ele como um sonho que está realizando. Nesse posicionamento euestudante do ensino superior, percebemos a deficiências atravessando os processos de desenvolvimento. Na universidade, João se depara com dificuldades e demandas inéditas que, se não atendidas, prejudicam seu aproveitamento educacional. As narrativas de entrevista revelam que a universidade ainda tem uma compreensão modesta das necessidades de adaptação dos ambientes, quando se trata da inclusão de pessoas com deficiências: limita-se a serviços como instalação de rampas, elevadores, adaptação de materiais e sinalização tátil. A a

\footnotetext{
${ }^{22} \mathrm{O}$ sistema de cotas na Universidade de Brasília obedece à Lei Federal $\mathrm{n}^{\circ} .12 .711$, de 2012, que estabelece cotas sociais (estudantes com renda de 1,5 salários mínimos per capita) e cotas raciais (estudantes negros, pardos e indígenas).
} 
negativa de uma professora em migrar para outra sala, longe dos ensaios do coral, como ação necessária para a inclusão de João exemplifica o cotidiano dos desafios para construir, nos espaços e com os atores, oportunidades equânimes de inserção.

As dificuldades enfrentadas contribuem para mobilizar o posicionamento eu-deficiente, que identificamos como resultado da relação entre a situação de estudante com deficiência e o contexto universitário, quando este não privilegia o estudante. Nossa percepção é que a posição eu-deficiente emerge e/ou se fortalece em situações sociais ou institucionais em que João, pela condição de pessoa com deficiência, se vê fragilizado, impedido de plena participação.

O cenário de inclusão ainda demanda avanços e é perpassado por resistência e preconceito. Retornaremos ao tema na seção de discussão dos resultados da pesquisa. Sintetizando, na ambivalência entre os significados relacionados à eficiência e deficiência, e nos eventos relacionados à inserção e ao cotidiano de João na universidade, eu-deficiente é a posição que se destaca (e - D). Como já afirmado, vivenciar situações de negação de suas demandas, menos-valia e resistência acaba por fortalecer o posicionamento relacionado à deficiência, consequentemente, enfraquecendo os significados que apoiam sua eficiência como estudante.

Mais uma vez, percebemos João diante de um evento de mudança, em que se torna necessário buscar formas de contornar a situação e se reorganizar para prosseguir. Ele, já no primeiro semestre, relata dificuldades relacionadas à sua capacidade de ouvir. Destaca o apoio de professores que o encaminharam ao sistema de apoio institucional da universidade, que mediou a troca de salas, minimizando a desvantagem imposta pelo excesso de barulho.

João menciona o apoio recebido por colegas e alguns professores, mas também a atitude de uma professora que se recusou a trocar de sala, restando-lhe como alternativa o 
trancamento da matrícula na disciplina. Ele afirma que o trancamento foi uma boa decisão e que não se sentiu prejudicado, pois teve oportunidade de cursar a disciplina em período posterior, com outro professor. E assim João vai nos indicando como, no cotidiano universitário, tem reagido às situações de dificuldade e preconceito. $\mathrm{O}$ excerto da entrevista a seguir destaca uma situação em que a vivência se desloca da posição eu-deficiente, pela utilização de recursos que apoiam sua permanência e aproveitamento:

toda disciplina, eu tenho direito a um tutor. Então, por exemplo, este semestre eu estou com três disciplinas e três tutores.

[...] Até porque uma das coisas que eu sempre falo com os tutores é isso: "Não me deixa viajar! Esteja sempre comigo! Me cutuca". Porque é isso, eu sempre disperso... Ficam comigo, ao meu lado mesmo, e normalmente eu sento no meio da sala, nas primeiras carteiras, pra ficar bem na frente do professor para não ter interferência. E aí eles fazem isso, me ligam, passam e-mail, perguntam se eu preciso de ajuda, nos trabalhos mais complicados eles querem estar junto para desenvolver e é isso, a missão deles é essa.

$\mathrm{Na}$ fronteira dos posicionamentos em ambivalência eu-deficiente e eu-eficiente está pautada a demanda por acompanhamento e apoio nas atividades acadêmicas. Na universidade, essas demandas são atendidas por meio do programa de Tutoria Especial ${ }^{23}$, ofertado pelo serviço de apoio. João expõe a situação da seguinte forma: necessita do tutor no seu acompanhamento cotidiano e precisa ocupar espaços específicos em sala de aula, preferencialmente no centro e à frente, o que favorece a leitura do movimento dos lábios dos professores. Caso contrário, a tendência é que ele se disperse nas atividades e não consiga ter bom aproveitamento.

João destaca que a presença do tutor é suporte importante para que suas dificuldades sejam superadas. A parceria do tutor materializa-se em mecanismo de compensação

\footnotetext{
${ }^{23}$ O Programa de Tutoria Especial consiste na disponibilização de tutores (colegas de classe ou alunos que já tenham cursado a disciplina) para cada disciplina que o estudante com deficiência julgar necessário. $\mathrm{O}$ tutor tem a função de acompanhar e ajudar o estudante em suas atividades acadêmicas, e recebe auxílio financeiro e/ou créditos.
} 
(Vygotsky, 1995), que lhe devolve a condição equânime de aprendizagem em relação aos colegas de classe. As ambivalências em tensão encontram equilíbrio de forma dinâmica, pois, embora a posição eu-deficiente se faça presente, as compensações feitas devolvem a João a eficiência, fortalecendo o eu-eficiente $(E-D)$.

A questão exemplifica como a existência de mecanismos adequados pode beneficiar o desenvolvimento acadêmico de João, dissipando os impedimentos da deficiência e devolvendo-lhe a condição de eficiência. Ao contrário da situação anterior, em que a deficiência é fortalecida e o diminui, na presente situação, João é empoderado e recupera o significado de eficiência e capacidade. Quando nossa atenção se volta às significações atribuídas por João a sua experiência no curso, ele diz:

eu adoro meu curso, abriu minha cabeça assim... sabe [abrindo os braços]? Eu me considero satisfeito com a [nome da Universidade]. Olha só, eu não sei se é porque era um sonho e eu estou aqui, e estou fazendo tudo para aprender, dentro do melhor e dando o melhor de mim... que eu... eu... [pausa] amo meu curso... e a gente aprende a ver isso no dia a dia, fazer a crítica, aprende a ter visão crítica.

Os colegas de sala todos me tratam muito bem. Começa que eu sou o vovô da sala. Já começa daí [risos]. Eles sempre tiveram muito carinho comigo, muita atenção e então, assim, sempre me ajudaram, independente de tutoria ou não.

A narrativa de João, nesse trecho, foca os ganhos que vem obtendo com o curso, os quais ele sintetiza como "aprender a ter visão crítica". Ele completa afirmando a importância do apoio recebido dos colegas de sala em seu desenvolvimento pessoal e acadêmico ao longo do curso, enfatizando a relação amistosa que tem com todos, que o denominam "vovô da sala". Como veremos, o papel dos colegas de classe é importante para os estudantes com deficiência, constituindo uma relação positiva com a alteridade. O papel da rede de apoio representada pelos colegas também é mencionado na carta enviada por João à pesquisadora, como veremos adiante. E, quando chamado a pensar no futuro, ele expõe suas intenções: 
eu quero trabalhar na minha área. Eu quero ir trabalhar com população ribeirinha, os pescadores. É uma categoria muito explorada e então quero trabalhar com eles, quero ir para uma cooperativa tentar levar conhecimento para eles, para que possam ser menos explorados.

As narrativas na parte final da entrevista apresentam suas antecipações de futuro, tanto para a conclusão do curso quanto para o exercício profissional. O senso de futuridade consiste no devir, no vir a ser, na relação intersubjetiva. É a relação entre a possibilidade de ser e não ser ainda (Valsiner, 2007; Simão, 2001).

É na carta escrita por João a pedido da pesquisadora que sua história volta a trazer elementos da trajetória estudantil. Ele recupera acontecimentos desde o momento da entrevista, ocorrida há um ano e três meses:

ainda estou às voltas com o meu curso. O fato de só fazer o estágio dois semestres depois da grande maioria da minha turma (eu não conseguiria fazer antes), fez com que, da mesma forma, o término do meu curso prorrogasse por mais dois semestres. Lembro que a maior parte da minha turma fez colação de grau em março.

Isso acabou por influenciar, e muito, no entusiasmo que tinha com relação ao curso. Iniciei o projeto no semestre passado, porém, foi um período em que o trabalho acabou por não permitir que eu o terminasse.

Os planos iniciais de conclusão do curso de João foram alterados, conforme lemos no trecho acima. Ele deixou de se aplicar para os estágios profissionalizantes por acreditar que não seria possível conciliá-los com suas obrigações no trabalho. Nessa ocorrência, a posição eu-trabalhador se impõe em relação à posição eu-estudante $(\mathrm{e}-\mathrm{T})$. Esse atraso adiou o término do curso e o levou à separação da turma.

Adiei para este semestre e estou na fase final para, a partir do próximo, escrever a monografia e defendê-la no final do próximo. Estou muito esperançoso que isso aconteça, até porque, o objetivo maior, agora, é concluir o curso. Estou muito cansado - e um cansaço de 61 anos.

Ao atrasar o início do estágio, atrasei, automaticamente, o número de semestres. Com esse atraso, acabei por pegar poucas matérias em cada um deles, resultado do 
desestímulo que me tomou conta. Porém, agora que vejo se encaminhar para o final, novamente estou a todo vapor. Tenho plena consciência da minha capacidade física e intelectual, motivo pelo qual aguardo com ansiedade o final do ano para comemorar mais essa vitória.

Ainda continuo com a intenção de trabalhar com os pescadores, daqui a três anos poderei fazer isso. Estou lutando para alcançar esta minha meta.

João fala de desânimo, dizendo-se cansado, mas ainda esperançoso de concluir o curso. Logo em seguida, o tom de seu relato se modifica, quando ele volta a focar o objetivo de se formar. Ele diz estar "a todo vapor", ao perceber que seu curso se encaminha para o final. Reafirma sua confiança e o desejo de alcançar seus objetivos, bem como de trabalhar com os pescadores, conforme havia relatado na entrevista.

Quando João expressa que sente "um cansaço de 61 anos", chama nossa atenção para uma ambivalência. De um lado, João se transforma dinamicamente, tal como um jovem universitário encontrando sua nova identidade profissional e vocacional (trabalhar com ribeirinhos). De outro lado, está em um momento do desenvolvimento em que sente a necessidade de apascentar o espírito, tal como alguém na transição para a velhice. João é, ao mesmo tempo e no mesmo contexto, um jovem universitário construindo uma (nova) identidade profissional e também um velho senhor, com uma identidade que acumula as experiências de seus 61 anos. Sua condição exemplifica a pluralidade, a dinâmica dos processos e a natureza relacional do desenvolvimento humano adulto.

Assim percebemos a dinâmica e fluidez dos processos de significação: numa mesma sequência narrativa, João apresenta dificuldades, desânimo e cansaço, mas também ânimo e autoconfiança para efetivar seus planos. Essa é a ambivalência entre ânimo e desânimo, desmotivação e esperança, cuja tensão revela o movimento de alternância das posições - o eu-deficiente perde força e dá espaço rapidamente ao eu-eficiente (e $-\mathrm{D} \rightarrow \mathrm{E}-\mathrm{d})$. 
O caráter dialógico e narrativo de composição do self se materializa em diferentes posições e alterna, ora de forma instantânea, em curtos espaços de tempo, ora de forma mais estável e duradoura (Lopes de Oliveira, 2014). A dinâmica com que os significados em ambivalência vão se deslocando entre as posições nos aponta pistas do movimento, do caráter fluido e das negociações que orientam o sujeito em direção a zonas de estabilidade.

Há peculiaridades que marcam o desenvolvimento, na fase adulta, de João: as ambivalências, a multiplicidade, a alternância entre posições. E assim se dá o desenvolvimento da identidade, que se reconstrói a cada nova configuração da trajetória, sem, entretanto, abandonar a estabilidade que the confere a capacidade de identificar-se como a mesma pessoa (Abbey \& Valsiner, 2005; Bastos, 2011; Cunha, 2007; Lopes de Oliveira, 2014).

O estudante, o trabalhador, o guerreiro, o deficiente, o eficiente, o teimoso, o vitorioso, o jovem e o senhor compõem a identidade de João. Isso nos permite inferir, da narrativa autobiográfica, como os significados se agruparam em determinadas posições e, por sua vez, como estas apoiaram a construção da trajetória de desenvolvimento.

\subsection{Maria: A inconveniente busca pela autonomia em resposta à deficiência visual progressiva}

Maria é uma jovem de 20 anos, filha única, que mora com os pais e tem retinose pigmentar, doença que causa baixa visão, cegueira noturna, quase inexistência de campo visual e visão central afetada. Teve uma trajetória na educação básica aparentemente bemsucedida no aspecto cognitivo, apesar de "problemas significativos", conforme relatou em entrevista, por sua condição de aluna adiantada em relação aos colegas de turma. Qualifica como "bastante" positivo o fato de ter iniciado sua vida escolar aos 2 anos e meio e conta que, 
mesmo antes disso, a mãe havia começado a alfabetizá-la — na escola, já "sabia ler praticamente tudo". Sobre a deficiência, ela menciona que estudou por muito tempo na mesma escola e, como as pessoas a conheciam, ajudavam-na em algumas situações, sem que ela precisasse pedir. A situação, segundo ela, era "natural" a ponto de só após sete anos ter sido percebida a deficiência visual. Maria usava estratégias que ocultavam a deficiência, por exemplo, não correr para não cair, e esperar que os colegas pegassem do chão seus objetos que caíam.

Seu acesso à universidade se deu no segundo semestre de 2011, para um curso na área de tecnologia. Aquele foi o primeiro vestibular que fez, e ela tirou a maior nota do curso naquele semestre, um dado de que diz gostar. Maria se mostra tranquila no momento da entrevista e, em nossa interação, infiro que é uma pessoa metódica, ponderada e eloquente, que se esforça em ser autônoma e valoriza seus pontos positivos.

Sua participação na pesquisa foi voluntária, mediada pelo sistema de apoio da universidade. Os contatos iniciais foram feitos por e-mail e telefone, momentos em que ela quis saber o teor da pesquisa e, após os esclarecimentos, apresentou as seguintes condições para conceder a entrevista: realizá-la no espaço da universidade, em lugar sugerido por ela (sala em que ela tivesse aula), a duração estimada e o término antes das 17 horas. Tais demandas se relacionaram à sua condição visual: no espaço em que ela já está presente regularmente, evitando deslocamentos (a universidade); em sala de aula que ela conhece e onde pode se situar de forma mais autônoma; e ainda, em horário que coincide com o final de uma aula e que, pelo tempo estimado, precisa se encerrar antes do anoitecer, por conta da redução de sua capacidade visual e do comprometimento de seu deslocamento.

Maria chegou pontualmente ao lugar combinado, a entrada principal do prédio de salas de aula do bloco de salas de aula, onde eu já estava à sua espera. Ela vinha dos andares 
superiores, descendo as escadas de forma autônoma, mas atenta. Ao chegar ao saguão do prédio, parou e ficou esperando. Aproximei-me, e me apresentei. Ela me convidou para voltarmos para sua sala de aula, no andar superior, e eu a acompanhei. Lá chegando, ela acendeu as luzes da sala, sentou-se numa cadeira bem ao centro da sala, e eu me sentei à sua frente. Conversamos por alguns instantes antes de começar a entrevista, e pude perceber sua intenção de se posicionar de forma calma e ponderada para falar de si e da trajetória estudantil.

Notei, ainda, certa reserva no início da entrevista, como se Maria não estivesse à vontade para falar ou não quisesse falar muito; porém, ao longo da conversa, ela foi se mostrando mais interessada em relatar sua trajetória escolar. Em dois momentos, fez questão de ressaltar fatos por ela denominados importantes: saber ler aos 2 anos e meio, e por isso ser promovida à série seguinte antecipadamente, e ser aprovada no primeiro vestibular que fez, com a nota mais alta para o curso que escolheu. A entrevista semiestruturada durou aproximadamente uma hora e todos os temas do roteiro foram abordados. Como na conversa com João, as intervenções em sua narrativa foram mínimas, feitas para inserir questões ou temas novos na conversa e/ou complementar informações.

Aproximadamente um ano após a entrevista, contatei Maria por e-mail e convidei-a a escrever uma carta, em que ela relatasse livremente acontecimentos que julgasse relevantes em sua vida no período desde a entrevista. O pedido foi prontamente atendido.

\subsubsection{A relevância do caso}

A escolha do caso de Maria para discussão mais aprofundada no estudo foi motivada por algumas questões. Uma delas é problematizar a compreensão da deficiência como fenômeno limitante, que direciona o olhar para significados negativos. A deficiência de Maria 
assume uma configuração de significado dinâmica, que impulsiona suas escolhas, busca adequar meios, organiza e reorganiza possibilidades de atuação em função das condições existentes no momento. Tal dinamicidade implica que a deficiência também está em desenvolvimento, quer na linha do tempo, quer na relação com o contexto em que o indivíduo está inserido. Por fim, o caso de Maria ilustra a compreensão da deficiência como fenômeno que exige atenção às singularidades de cada sujeito. Sendo assim, problematiza o papel das ações promovidas pelos sistemas institucionais de apoio à inclusão no espaço da universidade, perante os interesses e as demandas dos estudantes.

\subsubsection{A trajetória de Maria}

Como já mencionado, a abordagem da trajetória de vida e estudantil de Maria foi realizada em dois momentos: a entrevista semiestruturada e, um ano depois, a carta à pesquisadora. Nossa análise foca, inicialmente, a entrevista e, em seguida, aspectos extraídos da carta. A identificação, em ambas, de ambivalências e tensões entre posicionamentos, a partir das quais se acessa a dinâmica temporal dos processos de desenvolvimento da subjetividade, na forma de rupturas e transições, é um aspecto central desta pesquisa. Assim, os resultados do caso são apresentados tendo por mote dois polos de tensão: eu-eficiente/euinconveniente; e eu-eficiente/eu-deficiente.

Com a análise dos significados organizados pelo sujeito em torno de experiências percebidas como marcantes, busco identificar as transformações e os fatores que influenciaram a trajetória biográfica de Maria, tomando como ponto de partida a narrativa que ela (re)elabora sobre seu percurso escolar. 


\subsubsection{A tensão entre os significados eu-eficiente e eu-inconveniente}

Eu entrei na escola com 2 anos e meio. Minha mãe já tinha começado a me ensinar a ler antes disso, eu já entrei sabendo ler praticamente tudo. E na minha escola primária, a minha professora ensinava para a gente as vogais, as consoantes, a fazer a junção das letras, mas ela não ensinava ainda a ler porque a gente só precisava aprender as letras. Então, ela sempre escrevia as coisas, mas ela nunca esperava que a gente realmente lesse, ela só escrevia para a gente ir se familiarizando. Aí um dia ela escreveu "para casa", e tem o R que tem um som mais fechado, e tem o S com som de Z, então não era uma palavra, uma expressão tão infantil, então eu li e a professora ficou... ficou.... (pausa). E aí eles me transferiram para outra sala. E disseram que ou eu ia fazer outra série, ou ia sair da escola.

Maria narra as experiências iniciais de escolarização trazendo como personagens a mãe, que lhe apresenta as primeiras letras e a ajuda a entrar na escola "sabendo ler praticamente tudo", as professoras e a coordenadora da escola fundamental. Enquanto a mãe a ajuda a construir as competências que sustentam o posicionamento eu-eficiente, as educadoras provêm os significados que conformam a posição aqui denominada eu-inconveniente. A "inconveniência" está relacionada ao fato de terem sido surpreendidas por ela saber ler antes dos colegas, chegando a se queixarem porque ela estudava demais e importunava as aulas com perguntas em excesso. Essas experiências contribuíram para que Maria levasse da escola mais marcas negativas que positivas.

A minha vida escolar foi tranquila na maioria dos aspectos. Os únicos problemas significativos que eu tive foram relativos à minha aversão a lugares cheios, então eu não ia para os recreios e a coordenação da escola não aceitava; e também com o fato de eu sempre ter sido adiantada e alguns dos meus professores eram... esqueci a palavra... enfim, resistentes em aceitar alunos mais adiantados na sala. Porque eu entrei mais nova e pulei uma série, então eu era uma aluna adiantada em relação à turma.

Identificamos nas enunciações da participante a emergência de significados tensionados dialogicamente: inicialmente, os significados que perpassam pelos 
posicionamentos em tensão eu-eficiente, ligado a suas qualidades de estudante participativa, e eu-inconveniente, que passa a compor a subjetividade de Maria. Sua "inconveniência" se liga a dois aspectos: em alguns momentos, a capacidade de questionamento e a situação de adiantada em relação aos demais alunos, e em outros, o agravamento da deficiência visual.

Tive marcas negativas, mais que as positivas. Infelizmente... nas minhas escolas, a maioria dos meus professores me apoiou bastante e a coordenação da escola geralmente não implicava muito comigo, porque eu não fazia bagunça, mas em alguns momentos eles tinham bastante resistência. Por exemplo, quando eu era mais nova, era criança, a queixa mais frequente dos meus professores, que alguns deles faziam todo mês, era que eu estava colocando eles contra a parede, queria saber mais do que eles, porque eu estudava demais, eu sabia demais. E falava demais e perguntava demais, e eles não sabiam responder, e isso incomodava. Eles falavam com a coordenação para falar comigo, com a minha mãe e com a família inteira para eu parar de ser assim tão perguntadora. Eu era questionada porque participava.

A apresentação de Maria como estudante precoce, que incomodava os professores por suas elevadas habilidades cognitivas e se destacava pela alfabetização prematura, num primeiro momento, se associa à ideia de sucesso escolar e satisfação pessoal. Entretanto, o relato seguinte desloca-se da ideia de eficiência para a inconveniência que ela acreditava causar pelas habilidades cognitivas, pela participação, curiosidade e crítica. As posições eueficiente e eu-inconveniente encontram-se em tensão, destacando-se o eu-inconveniente nesse momento da narrativa $(\mathbf{e}-\mathbf{I})$. Embora possuidora de capacidades elevadas que poderiam destacá-la positivamente em relação aos demais alunos, ocorre o contrário: Maria vivencia situações em que é considerada pelos professores mais como aluna inconveniente e menos como aluna eficiente. 


\subsubsection{A tensão entre os significados eu-eficiente e eu-deficiente}

Ela [deficiência visual] começou a interferir há pouco tempo, na verdade, porque eu estudei numa escola em que as pessoas eram muito legais e sempre me ajudaram. E como eu estudei doze anos na mesma escola - eu entrei lá muito novinha e saí de lá praticamente adolescente —, então as pessoas sempre me conheceram, né, desde pequena, então era natural e nem sequer pedia nada para as pessoas. As coisas caíam e daí elas já iam e pegavam para mim, tipo assim, só devolviam.

Eu nunca pedi e elas também nunca viram nenhum absurdo em fazer isso. E eu não tinha nenhum problema em relação a isso. Tanto é que demorou sete anos para elas perceberem que eu tinha algum problema. Porque na escola não era aparente. Porque os quadros eram pequenos, então eu não precisava de visão periférica. Eu escrevia, eu não corria para não cair, então eu nunca caía, porque nunca corria. E aí ninguém percebia. Meus colegas pegavam tudo que caía no chão para mim. Então eles não percebiam que eu não enxergava. Demorou para perceberem, demorou muito.

A deficiência visual de Maria resulta de uma retinose pigmentar, doença de origem genética, degenerativa, sem controle ou cura conhecida. Embora presente desde sua infância, à época a deficiência ainda não era perceptível socialmente. Por isso, não parecia causar dificuldades incontornáveis a Maria. Assim, naquele momento, eu-deficiente ainda não constituía uma posição de destaque em sua organização subjetiva, prevalecendo a posição eueficiente, em que as capacidades e habilidades sociais (agregar condutas solidárias) e acadêmicas de Maria se mostravam suficientes para lhe garantir uma autoimagem fortemente relacionada à eficiência $(\mathrm{d}-\mathrm{E})$.

Mas nos últimos tempos, como é uma doença degenerativa, ela vem se agravando e eu não sei, eu acho que a partir do próximo semestre eu já não consigo mais ver os quadros, eu não sei como eu vou fazer para continuar aqui na [nome da Universidade], porque a locomoção aqui é mais difícil, e também eu estou começando a ter problemas que eu não tinha antes, de escrita, de leitura mesmo, de assistir às aulas. Então não sei, agora está incomodando bastante. Antes era tranquilo.

No trecho acima, a posição eu-deficiente ganha força, com a emergência de significados relacionados à progressão da doença e ao consequente agravamento da perda de 
visão. A acuidade visual cada dia mais reduzida faz emergirem limitações que impactam seu desenvolvimento e suas aprendizagens escolares.

Maria foca sua narrativa no passado recente, tempo que coincide com sua trajetória no ensino superior. Nesse cenário, as limitações se tornam mais efetivas pela crescente perda visual, condição que contrasta com as exigências do curso superior. As dificuldades vivenciadas (não enxergar o quadro; não ter apoio de alguns docentes; locomover-se para e na universidade) contribuem para modificar sua auto-organização e a levam a colocar em xeque a possibilidade de continuar a se perceber como estudante eficiente. $\mathrm{O}$ enfraquecimento da posição eu-eficiente resulta das dificuldades que ela passa a experimentar, em decorrência do choque entre a organização da universidade e a condição de pessoa com deficiência visual. Isso impõe limites à sua participação e ao exercício do ofício de estudante (Coulon, 2008). A posição eu-deficiente emerge com mais força e, aos poucos, torna-se dominante.

Eu decoro os lugares. Faço um mapa deles, para conseguir ir lá de novo. Por isso eu acho ruim quando mudam as coisas de lugar sem avisar. Porque quando muda é como se eu nunca tivesse andado lá.

E aí eu não ando muito aqui na [nome da Universidade]. Eu ando em poucos lugares, só nesses, é melhor.

[...] O objetivo dos slides, de não passar, era que a gente fosse forçado a copiar, mas eu não conseguia copiar. E eu queria copiar, mas dá para copiar. Então, eu disse: "você poderia, por favor, passar os slides? Tudo bem não poder passar para turma, mas eu não vou passar, eu quero ler e vou copiar em casa. Mas aí [o professor disse] "não, porque seria tratar diferente (risos). Se não posso mandar para ninguém, também não posso mandar para você".

O anfiteatro eu não consigo ir, quando caem aulas minhas lá, eu tento transferir, e se eu não conseguir eu tranco. Porque para mim não dá para assistir aula no anfiteatro... A sala é muito grande, muito longe, muito escuro.

Diante da força adquirida pela posição eu-deficiente em sua vida acadêmica, Maria enfrenta desafios no cotidiano do ofício de estudante (Coulon, 2008) e tenta reverter os posicionamentos que ressaltam suas dificuldades. Há um esforço de reconfiguração subjetiva 
para que ela alcance êxito na formação acadêmica e consequente fortalecimento da posição eu-eficiente, por meio da busca por alternativas de estudo e adequação de meios.

Porque é chato incomodar as pessoas. Elas não têm nada a ver com meu problema. Incomoda, eu sei que sempre incomoda as pessoas. Então por isso eu só peço quando é muito necessário.

Ah, todo mundo tem coisas para se preocupar, então você acrescentar mais uma nunca é legal. Então, por exemplo, o professor já tem que tirar um monte de provas, corrigir um monte de provas, então eu só peço para ele uma prova extra, uma prova diferente, ou tempo extra, ou uma prova com xerox diferente quando realmente é necessário, porque é mais um problema para ele resolver. Então, assim, isso não deve ser bom.

Eu sei que eu tenho alguns direitos, até de papel passado aqui na [nome da Universidade]. Mas, assim, eu procuro ser tão parecida e ter o tratamento tão parecido com os outros quanto eu posso. Então, são raras as coisas, muito raras. Alguns professores nem percebem que eu não enxergo. Porque o que eu faço é só sentar na frente, bem na frente sempre, desde sempre. E fazer mais perguntas do que o normal que eu faria, porque tem coisas idiotas que eu não consigo ver no quadro, e daí eu pergunto e o professor fica achando que eu sou burra, porque estou perguntando coisas óbvias, mas é porque eu não consigo ver, mesmo.

Com base nos excertos da narrativa apresentados acima, Maria vai focar a maneira como atribui significado a sua deficiência na relação com a alteridade. A presença dos "outros" com quem Maria interage e se relaciona em sua trajetória escolar ganha destaque. Segundo Valsiner (2012), os "outros" podem ser as pessoas reais, os outros sociais (reais ou imaginários) e, ainda, as vozes dos outros. É por meio dessa relação com os “outros” que configuramos e reconfiguramos posicionamentos, de tal forma que a subjetividade está sempre sendo mediada por nossas relações (Valsiner, 2012). Em vários momentos da narrativa de Maria, a alteridade é chamada à cena e se torna o meio pelo qual ela expõe e justifica seus posicionamentos.

A ênfase de Maria está na compreensão da deficiência como característica e responsabilidade pessoal do deficiente, atribuindo a si mesma a função de adaptar-se a um contexto que, a seu ver, não tem a obrigação de ser inclusivo. Ela chega a relatar que a 
deficiência incomoda as pessoas e que abre mão dos próprios direitos a fim de não perturbar. Partindo dessa compreensão, Maria internaliza posicionamentos relacionados à desvantagem criada pelos sistemas sociais pouco inclusivos, ao longo de seus anos de inserção na escola e na universidade.

Maria toma para si a responsabilidade de se incluir, mesmo que isso represente a negação de suas dificuldades e necessidades. Com essa iniciativa, reproduz signos hipergeneralizados na universidade. Os signos hipergeneralizados estão presentes na cultura coletiva e são regulados por um sistema de crenças, que guiam sentimentos, pensamentos e ações das pessoas num dado contexto (Valsiner, 2007). Na universidade, eles estão ligados à eficiência, ao mérito e à autonomia que se espera de todos os estudantes, mas que estão em tensão com as necessidades dos estudantes com deficiência.

Esses signos são norteadores e esperados de todos os estudantes. Ao se inserir nesse contexto, Maria tem consciência de que também são esperados dela. Por isso, a fim de não violar os valores já estabelecidos, ela incorpora a necessidade de demonstrar a eficiência, a autonomia e o mérito esperados, negando-se a receber a ajuda que poderia lhe garantir condições mais equânimes de permanência na universidade.

As condições em que se desenrola o ensino superior organizam as posições em tensão de forma que o eu-deficiente se sobreponha ao eu-eficiente — nesse caso, por imposição do sistema semiótico que orienta as práticas na universidade $(\mathrm{D}-\mathrm{e})$. Percebo que a deficiência é um indicador semiótico que, em dadas situações, canaliza a trajetória do desenvolvimento, enquanto em outras, embora presente como elemento constitutivo da subjetividade, não tem força para tanto, e assim a trajetória é guiada por outros significados.

Importa destacar que a compreensão que naturaliza a associação entre deficiência e significados como limitações, barreiras permanentes, dificuldades insuperáveis, é substituída 
por uma nova visão. Entra em cena uma concepção mais ampla e crítica de deficiência, concebida como fenômeno de manifestação relacional, ligada a atitudes de empoderamento ou enfraquecimento. A depender da presença ou ausência de mecanismos inclusivos na sociedade, os sujeitos com deficiência se tornam capazes (empoderados) ou são incapacitados (enfraquecidos) de participar em condições de equidade. Ainda há outros significados que se organizam em torno da ambivalência eu-eficiente e eu-deficiente.

Eu preciso de luzes. Minha casa é toda branca, do chão ao teto. É toda branca e não tem nada, não tem cantos, não tem pontas. Não tem declives, não tem nenhuma assimetria no chão, não tem móveis no meio da casa, não tem móveis que podem ser muito mudados de lugar, e tem luzes em todos os cômodos. Luzes brancas e fortes, então para ficar realmente acessível para mim, a partir das seis da tarde, teria que ser assim, mas aí [na Universidade] não tem como fazer.

Esse trecho evidencia as percepções de Maria sobre as demandas ligadas às atividades de vida diária e acadêmicas. Seu relato informa suas necessidades para o alcance de condições de equidade, autonomia e empoderamento, em que a deficiência visual não se torne um limitador, quer em casa, quer no contexto acadêmico. Entretanto, reafirma sua responsabilidade pessoal de enfrentar os desafios para adaptação e aproveitamento da experiência universitária, desconsiderando o campo das ações de responsabilidade da universidade para a inclusão.

Subjetivamente, os significados da posição eu-eficiente, persistentes em manter sua autoimagem de estudante bem-sucedida, impulsionam suas ações e estão relacionadas aos signos hipergeneralizados em torno da lógica meritocrática da universidade. Maria se organiza de modo a criar mecanismos pessoais de resposta a essa lógica, numa tentativa de se inserir no sistema.

A parte final da entrevista se volta às suas perspectivas para a conclusão do curso de graduação e a continuidade dos estudos. São significados organizados de modo a 
proporcionar-lhe condições de reequilibrar eu-eficiente e eu-deficiente: "pretendo fazer pós. Fazer o mestrado aqui [na [nome da Universidade].] e o doutorado em São Luís [Maranhão]. Na minha área de formação, mais especificamente nos desdobramentos do campo". Apesar das dificuldades, Maria reorganiza-se subjetivamente em busca de uma síntese, em que as posições eu-eficiente e eu-deficiente, embora em tensão, fundem-se para apoiar seus processos de desenvolvimento de forma prospectiva.

Quando solicitada a escrever uma carta à pesquisadora, decorrido um ano desde a entrevista, Maria relata novidades importantes sobre a trajetória estudantil. Ela narra uma tomada de decisão radical: mudou de curso, por haver antecipado que o agravamento de sua deficiência visual não seria compatível com a prática profissional.

De lá para cá, muita coisa mudou.

Desde o meu terceiro semestre na [nome da Universidade], eu nunca fiz o mínimo de créditos por semestre, e portanto já estava mais próxima da formatura do que um aluno no fluxo regular do sexto semestre. Iniciei o processo de procurar por estágios no fim do sexto semestre, mesmo que só pudesse fazer dali a um ano ou seis meses, e ocorreram contratempos.

O curso em si não me ofereceu o que eu esperava. Após algumas conversas com meu orientador, percebi que, para me formar [nome da Universidade] [...], eu precisava de um estágio ligado diretamente ao setor de produção de uma indústria (no "chão da indústria", como é comumente chamado). Eu tenho consciência da minha limitação visual e entendo que a minha presença em um ambiente "chão de indústria" [...] seria um risco para mim e para os outros.

Para mim, era claro que eu não iria realizar um estágio neste setor específico de uma indústria. Fui aconselhada a mudar de curso.

Destacamos, na carta, a força que os signos hipergeneralizados, como aqueles que reforçam no sujeito formas esperadas de ação, e que no caso se relacionam à presença de autonomia e eficiência, exercem sobre sua subjetividade. A posição eu-deficiente ganha força em virtude das antecipações de futuro que Maria faz, em que a deficiência visual passaria a representar um impedimento importante à sua formação e à sua atuação profissional (e - D). 
A decisão de mudar de curso retrata aspectos de auto-organização. Diante de uma barreira colocada pela condição de deficiente visual, e tendo seu projeto de vida ameaçado pela possibilidade de fracasso, Maria reorienta sua trajetória. Como ela compreende que a inclusão é uma responsabilidade pessoal, a opção pela mudança de curso é aparentemente orientada pela necessidade de fortalecer a posição eu-eficiente, mesmo que isso represente uma mudança drástica $(\mathrm{E}-\mathrm{d})$.

Iniciar um novo curso, mesmo fazendo o aproveitamento de disciplinas, representa uma decisão séria e com importantes desdobramentos, tendo em vista a perda progressiva da visão e a possibilidade de cegueira total ainda durante a nova graduação. Como temos enfatizado, a busca pela eficiência constitui um marcador semiótico de grande destaque, e mesmo orientador da trajetória principal, influenciando a tomada de decisões e promovendo a emergência de novos signos, que vão apoiá-la na busca de seus objetivos.

No trecho final da carta, Maria expõe suas perspectivas de estudar e estabelecer vida fora do país, o que apoia nosso entendimento sobre a importância dos signos de autonomia, eficiência e realização que a acompanham e compõem sua auto-organização e seu senso de futuridade. Para Valsiner (2012), mesmo imprevisíveis, os signos que se organizam como guias para construções possíveis são promotores: assumem uma função prospectiva para os significados nas experiências futuras.

Desse modo, a relação de Maria com a deficiência assume uma configuração de significados dinâmica, que em algumas situações impulsiona sua trajetória. Pela busca de adequar meios, organizar e reorganizar possibilidades, fazer compensações, em função das condições de cada novidade experienciada, Maria vai traçando uma trajetória de desenvolvimento dinâmica e não determinista. $\mathrm{E}$, em virtude de seus modos particulares de lidar com a condição da deficiência visual, esta não se constitui um limitador da trajetória de 
Maria, mas um significado em torno do qual ela é reconfigurada. A compreensão vai ao encontro da concepção de deficiência sem a atribuição de valores que possam limitar a existência do sujeito.

Percebo o esforço de Maria em encontrar a síntese entre as posições eu-eficiente e eudeficiente, de modo a permitir a emergência de outras possibilidades de desenvolvimento. $\mathrm{O}$ caso de Maria ilustra a compreensão de deficiência como fenômeno em desenvolvimento. E, assim, escapa a concepções determinísticas que associem deficiência a processos genéricos de ação para a inclusão, em que não se considera o caráter singular da deficiência como fenômeno ligado às condições e experiências individuais do sujeito.

\subsection{Alice: De (má) aluna à lutadora por direitos}

Alice é uma jovem portuguesa de 22 anos, solteira, filha única de pais separados, que mora apenas com a mãe e possui diagnóstico de dislexia. Teve uma trajetória escolar marcada por dificuldades, incompreensão e sofrimento. Ingressou na escola aos 6 anos e teve muitos obstáculos, que ela narra como "atraso verbal, dificuldade em acompanhar, em falar como os outros e se exprimir", e ainda "acompanhar" o desenvolvimento das atividades. Foi encaminhada à terapia fonoaudiológica, pois a crença era de que suas dificuldades seriam apenas verbais. Após dois anos, superou as dificuldades relacionadas à linguagem oral deixou o acompanhamento fonoaudiológico.

No entanto, Alice teve dificuldades também relacionadas à escrita, que se manifestaram, segundo ela, desde que começou a escrever. Ela conta que essas dificuldades permaneceram compreendidas, tanto pelos pais como por professores, como decorrentes de distração, desmotivação, desatenção, ao longo de 11 anos na educação básica. Destaca que ela 
mesma não se via assim, que se esforçava em "combater ao máximo" o problema, mas não conseguia superá-lo. No décimo primeiro ano de escolarização, um de seus professores, ao perceber suas dificuldades, a chamou para conversar. Ele identificava na estudante características de dislexia, um distúrbio que ele também tinha, e a encaminhou à psicóloga da escola. Teve início um processo de investigação que culminou na confirmação do diagnóstico.

Seu acesso à universidade se deu em 2011, para um curso na área de licenciatura, por meio dos exames ${ }^{24}$, ao final do $12^{\circ}$ ano. Na ocasião, ela ainda não possuía laudo que lhe garantisse atendimento diferenciado. Foi estudante em duas universidades no norte de Portugal. A primeira universidade foi acolhedora, mas, na possibilidade de precisar cursar disciplina com uma professora que, segundo Alice, não acreditava na dislexia, a aluna preferiu transferir-se para a segunda universidade, com a expectativa de encontrar mais apoio, o que não ocorreu. Alice relata que se decepcionou, pois vivenciou mais dificuldades na nova instituição que na anterior.

No momento da entrevista, Alice se mostrou atenciosa e eloquente. De nossa interação, infiro que ela é uma pessoa esforçada, perseverante e assertiva. Na entrevista, emocionou-se ao lembrar o momento de contar sobre o diagnóstico para a mãe. A interação das duas, mediada pelo desempenho acadêmico de Alice, que era considerado insatisfatório, fora marcada ao longo dos anos por incompreensões e castigos. Também se emocionou ao falar sobre o curso superior, que estava em vias de finalizar (cursava o último ano), e sobre as poucas possibilidades de atuação em sua área de formação, como professora.

Sua participação na pesquisa ocorreu de forma voluntária, mediada pelo serviço para a inclusão. O contato inicial foi feito pela pesquisadora por e-mail. Como Alice manifestou

\footnotetext{
${ }^{24}$ Em Portugal, o acesso às universidades públicas se dá por meio de exames nacionais de conhecimento, realizados ao final do $12^{\circ}$ ano de escolarização. De acordo com a nota obtida no exame, o estudante pleiteia uma das vagas oferecidas pelas universidades do país.
} 
interesse em participar da pesquisa, a entrevista foi marcada para o espaço da universidade, em horário após sua aula no turno matutino. Ao chegar ao local, Alice se aproximou, andando rapidamente, e me perguntou se eu era a pesquisadora. Ela me convidou a segui-la para uma área de convivência dos alunos, no bloco em que estávamos. Após as apresentações pessoais e a formalização do convite, com a exposição dos objetivos da pesquisa e leitura do TCLE, Alice ratificou seu interesse em conceder a entrevista.

A conversa teve a duração aproximada de uma hora e vinte minutos, em que todos os temas do roteiro foram abordados. Ela fez sua narrativa, destacando livremente os aspectos que julgava mais relevantes. As intervenções da pesquisadora no fluxo da narrativa foram feitas em alguns momentos, tanto para inserir questões ou temas novos à conversa quanto para pedir que ela complementasse informações. De forma geral, o relato de Alice entrelaçou sua trajetória pessoal e estudantil.

\subsubsection{A relevância do caso}

Aprofundar nossa análise com base caso de Alice nos parece relevante para a pesquisa por diversas questões. De início, a compreensão da deficiência como fenômeno desconhecido (até determinado momento) para o sujeito e os impactos da falta e/ou presença de um diagnóstico. Também é relevante o fato de ela ser uma estudante de Portugal, o que nos possibilita uma aproximação da realidade de estudantes com deficiência naquele país. 


\subsubsection{A trajetória de Alice}

Nossa análise está apoiada na narrativa de Alice, ao longo da entrevista, sobre sua trajetória de vida e escolar ${ }^{25}$. Identificamos as ambivalências e tensões entre posicionamentos que nos permitem interpretar, como já destacado nos demais casos, a dinâmica temporal dos processos de desenvolvimento de sua subjetividade, na forma de rupturas e transições. Os resultados do caso são apresentados considerando-se dois polos de tensão que se depreendem de suas narrativas: eu-má aluna/eu-informada, identificadas como (M/m - I/i); e eudiferente/eu-deficiente, (Df/df $-\mathrm{D} / \mathrm{d})$, registradas em maiúsculas e minúsculas conforme a alternância de força entre as posições.

\subsubsection{A tensão entre os significados eu-má aluna e eu-informada}

$\mathrm{Eu}$, do primeiro ao décimo primeiro ano, não fui detectada enquanto aluna com necessidades educativas especiais. Eu fui detectada como uma aluna desatenta, desinteressada, e uma aluna com muitas características que me davam castigos em casa porque minha mãe achava que eu era do pior.

Eu não conseguia perceber como eu era assim. Porque de fato, eu não era assim, eu era atenta, eu me concentrava, mas me concentrava a sério para tentar escrever as coisas, portanto eu tentava ao máximo combater isso. Mas realmente eu não conseguia.

Já no início do relato de suas experiências com a escolarização, Alice aponta os problemas que enfrentava na relação com as alteridades da escola. Era má aluna, a quem os professores não conseguiam ensinar, por considerarem desatenta, desinteressada. O tratamento que recebia em casa, decorrente do mau desempenho escolar, era "do pior”, alusão ao

\footnotetext{
${ }^{25}$ Um ano após a entrevista, Alice foi contatada por e-mail, em que lhe foi feito o convite de escrever uma carta à pesquisadora; entretanto, após várias tentativas, Alice não respondeu. Assim, não foi possível contar com esse instrumento na análise.
} 
desempenho insuficiente e inadequado, que na compreensão da mãe precisava ser corrigido por meio de castigo. Somava-se à situação a incompreensão das dificuldades. Embora Alice se esforçasse e se considerasse atenta, o resultado de suas atividades não era condizente com o investimento, gerando uma tensão em torno das formas como ela se identificava. Ela segue abordando essa tensão, que, como veremos, culmina na preponderância dos significados relacionados à posição má-aluna.

Eu lia aquilo e pensava: "meu Deus, como é que pode? Isso não faz sentido nenhum! Como é que eu escrevi isso?" Eu própria tinha consciência disso e eu tinha consciência que aquilo não fazia sentido. Realmente eu era muito má. E aquilo era mesmo mau. E os professores diziam: "Tu és mesmo má! Má aluna".

Eu tive uma professora de francês que, numa altura de fazer um exercício, e eu não conseguia fazer o exercício em português, quanto mais francês, e ela em frente à turma toda me disse: "Tu és um zero! Tu és um zero! Eu não consigo fazer nada contigo". E eu disse: "não consegue mesmo fazer nada comigo, eu sou mesmo má!" E tive essa ideia ao longo desses anos todos.

Os excertos acima exemplificam a força exercida pelos significados que fizeram Alice se autoidentificar como má aluna sobre a organização de sua subjetividade. Tal identificação dá conta de diversas situações, na relação com os professores e a mãe, em que foi sendo construída a imagem de si associada a incompetência, incapacidade, distração, desinteresse. A isso se acrescenta a tensão vivida por ela, por perceber que a lente pela qual a viam não coincidia com seu esforço: tentar se concentrar, esforçar-se na realização das atividades, sem compreender como suas tentativas lhe rendiam resultados tão negativos.

Um indicador da inexistência de déficit intelectual é a crítica que Alice era capaz de direcionar às suas dificuldades de concentração, quando identificava que o que produzia ou interpretava "não fazia sentido". Mesmo assim, ela internalizou os significados sociais que a identificavam como má aluna, não conseguindo resistir à força de significados já construídos e mediados pelos outros $(\mathbf{M}-\mathbf{i})$. Assim se conformou a posição eu-má aluna, que se destacaria 
ao longo de onze anos de escolarização de Alice. A mudança que resultaria na emergência de outra posição começou a se configurar no décimo segundo ano escolar:

até que apareceu um professor com história de dislexia, que, ao ver uma reação minha, disse: "alto! Isso me é familiar. Vamos ver o que é que se passa aqui”. E encaminhou-me para um psicólogo.

E ele daí me disse: "não! Você é disléxica. Eu sou disléxico e eu reconheci-a pelas características. Se você consentir, eu a encaminho para a psicóloga da escola e vamos começar o percurso".

Nos recortes que informam sobre o processo de atribuição do diagnóstico de dislexia, percebemos que Alice se torna capaz de ressignificar as dificuldades vividas. Acostumada ao rótulo de má aluna recebido ao longo da trajetória escolar, ela foi surpreendida pela hipótese levantada por um professor, que se propôs a apontar-lhe uma alternativa e direcioná-la ao profissional capaz de verificar sua hipótese. Como o próprio professor se reconhecia como disléxico, ao perceber em Alice características associadas a essa condição, concedeu a ela um apoio que nenhum professor lhe tinha oferecido.

A ação do professor é descrita por Alice como positiva, uma oportunidade para identificar a origem de suas dificuldades e assim poder combatê-las:

Mudou, mudou... mudou muito. O diagnóstico mudou a mim, porque eu passei a ver que, afinal, eu não era assim tão má. Que havia um motivo para eu ser assim. E nós, ao sabermos o motivo, já temos armas para o combater. E já não estava sozinha, havia outras pessoas para me ajudar a combater.

Depois que eu descobri que era disléxica, meu sentimento foi de uma enorme revolta com todos os professores que tive. Uma revolta enorme. Como é que nenhum se deu ao trabalho de pensar: porque ela é assim tão má?

Agradeço os psicólogos e esse professor, que foi fenomenal para mim.

Alice afirma com convicção que houve mudanças em sua percepção sobre os processos educacionais desde o diagnóstico de dislexia, as quais lhe permitiram ressignificar a autoidentificação como má aluna. Além disso, ao conhecer a origem de suas dificuldades, ela passou a ter possibilidades de combate e busca de apoio. 
A forma pela qual Alice se organiza diante da novidade - o diagnóstico — leva ao surgimento de uma posição antes inexistente, que passa a orientar a subjetividade de Alice: o eu-informada. A novidade lhe permite ressignificar as dificuldades vivenciadas até então, por meio do acesso a informações que a fazem conhecer melhor seu funcionamento. Com a emergência da configuração eu-informada, a posição eu-má aluna, que até então predominava, foi abalada. A posição que representa o diagnóstico e as possibilidades que ele abre é a de sobreposição do eu-informada ao eu-má aluna (m - I).

\subsubsection{A tensão entre os significados eu-deficiente e eu-diferente}

E quando eu disse à minha mãe, disse-lhe: "vês, mãe? Eu afinal não era assim tão má, eu sou disléxica”. E ela disse-me: “o que é isso?” E eu expliquei e disse: “depois de tantos castigos que me destes" - porque minha mãe me dava muito castigos, era muito difícil —, "veja, eu não tinha culpa. Eu não tinha culpa de nada disso. Eu era inocente, afinal! Eu tenho é uma deficiência, sou uma pessoa que precisava de um acompanhamento específico...” E ela chorou.

A partir desses novos significados, que a fizeram ampliar a compreensão de sua condição como estudante, Alice passou a agir mais ativa e empoderadamente. Ela saiu do lugar de quem se autoidentifica a partir do olhar de reprovação do outro, o que modificou a relação que mantinha com a alteridade. Seu primeiro alvo foi a mãe, no trecho que destacamos acima - aquela mãe que cobra e castiga, acreditando que assim poderia corrigir os problemas de desempenho escolar, é instada a reconhecer sua ignorância e seus erros no modo de conduzir a vida acadêmica de Alice. Ao afirmar que fora castigada sem que houvesse culpa, e sim uma deficiência, ela introduziu um signo no sistema de significados pelos quais não só os outros, mas ela própria a identificam. Desse modo, deixou de se posicionar como a aluna má e assumiu a imagem de alguém com "uma deficiência", que por isso "precisava de 
acompanhamento específico". Tem lugar, nesse momento, uma nova posição associada ao diagnóstico de dislexia, que ela mesma denomina como deficiência: o eu-deficiente (Df - d).

Como esta seção não se concentra na discussão da dislexia e seus dilemas, limitamonos aqui a interpretar a associação que Alice faz da dificuldade que possui com a deficiência ${ }^{26}$. Por se tratar de uma estudante com histórico escolar marcado por dificuldades acentuadas de inclusão - e correspondentes a signos identificados por Alice como deficiência —, julgamos pertinentes analisar o caso. Entendemos que o debate é polêmico e não pretendemos sustentar que a dislexia seja mais bem definida como deficiência, mas interessa expor de que forma as universidades têm recebido e lidado com as demandas e a diversidade. E, como o termo “deficiência" é enfatizado por Alice, optamos por mantê-lo, como posicionamento identitário que lhe possibilitou conhecer a dislexia, ressignificar sua autoimagem e vislumbrar outras possibilidades a partir desse evento. Ela relata:

\begin{abstract}
a nível pessoal, eu acho que me senti muito melhor, porque já percebia aquilo que tinha, percebia que tinha que saber como melhorar aquilo que tinha e comecei a ver, realmente, que as pessoas que me rodeavam podiam me ajudar a não ser tão má. A ser melhor. E cabia maneiras de controlar isso.
\end{abstract}

Como ilustra o excerto acima, processos de diagnóstico se mostram eventos promotores de desenvolvimento humano quando se convertem em meio de acesso à informação e de autoconhecimento, e ainda quando alimentam a capacidade humana de reação aos desafios. Também foi ressignificada a relação de Alice com a alteridade, conforme dissemos acima, pois os outros que antes a consideravam "má" agora são parte daqueles que podem ajudá-la a superar dificuldades.

Portanto, eu se fosse acompanhada do início, se fosse detectada no básico, fosse acompanhada inicialmente, se houvesse aqui uma ajuda, eu ia poder ser uma pessoa muito melhor, muito mais brilhante, muito mais... a nível escrito, eu ia conseguir ser

\footnotetext{
${ }^{26}$ Nossa reflexão sobre isso será exposta na seção de discussão dos resultados.
} 
muito melhor. Porque eu ia ter um acompanhamento e ia poder haver uma inserção mais precoce e, aliás, dislexia é tratada precocemente - quanto mais precoce, melhor.

Hoje leio imenso, dizem que melhora, que faz efeito. Escrevo imenso para tentar corrigir...

Os enunciados de Alice, acima, envolvem uma avaliação do passado acadêmico e são recheados de “e se?”, um exercício de recriação de passados alternativos, caso o diagnóstico tivesse sido precoce. Tais passados alternativos criam zonas de ambivalência (Abbey \& Valsiner, 2005) e abrem perspectivas para o deslocamento de Alice perante os signos que a identificavam como "má aluna" para novos futuros imaginados, relacionados a tornar-se "melhor", a ter o poder de controlar as dificuldades. Inclusive, por conhecer melhor as características e dificuldades próprias da dislexia, Alice adota dispositivos que minimizem o insucesso, como ler e escrever muito, explorar os recursos do computador que ajudam na revisão de sua escrita, ou ainda a constante releitura dos conteúdos do curso.

Também nos recortes percebemos como a emergência do signo dislexia definiu e transformou a dificuldade desconhecida, que diminuía Alice perante a alteridade, em um significado capaz de reduzir as angústias e lhe tirar a "culpa". Constatamos aí uma descontinuidade na linha do desenvolvimento, posicionando Alice entre a tensão "como sou" e “como poderia ser" (Valsiner, 2012). Tal descontinuidade revela as transições que levaram Alice a elaborar outros significados e, assim, outra forma de auto-organização (Cunha, 2007; Valsiner, 2012; Zittoun, 2008), e uma nova posição em construção.

O computador é uma ferramenta essencial para mim. Eu não consigo fazer nada sem computador nesse momento. A nível escrito, preciso ter um computador. Nem tenho confiança de escrever à mão. Eu escrevo à mão, mas o que escrevo só eu é que leio, não deixo mais ninguém ler. E o computador, aí está, é o meu escudo, é aquilo que me vai proteger para, a nível escrito, não ter dificuldades.

Porque minha dificuldade é entender o que eu leio e escrever. Eu leio mais vezes que os meus colegas, leio muito devagar, e assim preciso sempre ler mais vezes para 
compreender como eles compreendem... Eu preciso ler mais vezes e mais devagar para processar melhor, enquanto os meus colegas não.

Reconhecendo-se a partir do diagnóstico de modo diferente e num esforço para superar as dificuldades advindas da dislexia, Alice vai criando e se apegando a ferramentas e alternativas que atuem como mecanismos de compensação (Vygotsky, 1995); ao mesmo tempo, vai se dando conta de que sua condição a distingue dos colegas de turma. Percebemos, nesse trecho do relato, maior ênfase à diferença constitutiva, que exige acionar mecanismos de aprendizagem específicos, do que à possível inferioridade ou desvantagem. Esse conjunto de significados, correlacionamos à posição eu-diferente (df - D).

É a possibilidade de usar as ferramentas e os meios que ela identifica como adequados em proporcionar condições mais equânimes de desenvolvimento que fortalecem a posição eudiferente, de forma a diminuir os impactos da posição eu-deficiente. Vygotsky (1995), em seu Tratado de Defectologia, afirma que a cabe à educação auxiliar na criação de técnicas artificiais, culturais, em um sistema de signos ou símbolos adaptados às peculiaridades da organização psicofisiológica da pessoa. Com isso, surgem mecanismos capazes de, ao compensar o "defeito", impedi-lo de se tornar uma "desvantagem", diminuindo as dificuldades impostas pela sociedade. Quando Alice acessou o ensino superior, já conhecia suas dificuldades e as formas de compensação, assim como tinha consciência da relação entre superação de dificuldades e contexto institucional da universidade. Ela relata:

Portanto, eu entrei para a universidade sem o estatuto. Antes da universidade, eu não tinha qualquer tipo de estatuto.

Eu comecei no [nome da universidade] e não me desiludiu em nada. Eu esperava que a minha luta fosse maior ainda. Era o primeiro ano com o estatuto e era tudo novo. Mas tive pessoas que posso dizer, andaram comigo ao colo. Me ajudaram imenso. Pessoas que me acompanharam e foi muito bom.

Expuseram formas que nos poderiam ultrapassar os problemas.

Quando eu vim para a universidade [nome da segunda universidade], foi uma desilusão, e eu fugi de lá por causa disso. Porque eu sabia que ia lidar com uma 
professora que não acredita em dislexia, que não acredita em nada dessas deficiências. Isso para ela é tudo enganação! E eu, como sabia que ela ia ser minha professora, eu vim para cá, porque não ia dar em nada. Tinham me dito que era uma universidade mais familiar, mais próxima, e não foi nada disso.

Alice destaca que seu acesso ao ensino superior se deu sem que ela fosse amparada por nenhum laudo que lhe permitisse atendimento diferenciado. Em Portugal, são garantidas condições diferenciadas (adaptações em geral) no sistema de acesso ao ensino superior para os estudantes com deficiência devidamente comprovada. Sem o laudo, a estudante acessa o ensino universitário em condições regulares. Por isso, Alice imaginava enfrentar um desafio ainda maior, em decorrência da novidade e da antecipação da experiência universitária como algo desconhecido.

$\mathrm{Na}$ primeira universidade, em que foi bem recebida e encontrou apoio e acompanhamento, ela ressalta a relevância desse suporte em sua jornada acadêmica. Entendemos que, em virtude das características contextuais dessa experiência inicial, as posições eu-deficiente e eu-diferente estiveram em equilíbrio. A dislexia não determinou dificuldades marcantes, nem sua identificação como diferente $(\mathrm{df}-\mathrm{d})$.

Contudo, mesmo na existência de apoios julgados relevantes por Alice, que a carregaram "ao colo", houve dificuldades significativas. Ao saber que seria aluna de determinada professora, que se mostrava pouco compreensiva em relação a sua condição de disléxica, e antecipando que não conseguiria desenvolver um bom trabalho, Alice tomou uma atitude radical e mudou de universidade. Nesse episódio, ganha força a posição eu-deficiente, pois, nas antecipações de futuro, um professor que não acreditasse na dislexia como causa de dificuldades acadêmicas poderia representar um impedimento aos seus objetivos (Df $-\mathrm{d})$.

Ao ingressar na segunda universidade, em vez de encontrar um espaço mais acolhedor e sensível às diferenças, Alice passou a vivenciar dificuldades ainda mais severas: 
e chegava ao final do ano e a gente entrava com o computador e eles (professores) diziam: "não pense que vai passar da nota $\mathrm{X}$. $\mathrm{E}$ isso até hoje, aqui na universidade [nome da universidade] até acontece mais que na universidade [nome da universidade], posso dizer que dei-me [na primeira universidade] com dois casos durante um ano e aqui bem mais.

É alguém [o professor] que é cético perante a multiplicidade de pessoas, é alguém que é cético para as mudanças.

Aliás, há professor aqui na universidade, do Instituto [nome do instituto], que declara que não acredita na dislexia. E que já foi chamada ao [órgão responsável pela inclusão na universidade] e continua a manter a posição de dizer que não acredita. E pronto! Então todos os alunos que lhe caem à mão, não vão conseguir bom rendimento. Então há essa partilha de ideias, entre nós e eles. Tem aqueles que apoiam, ajudam, e tem outros que não, aí você está sozinho, boa sorte! Não digas que tem algum tipo de deficiência, porque não vai resultar.

Alice expõe as dificuldades que enfrenta na negociação com a alteridade, neste exemplo representada pelos professores da universidade. São situações que reportam a inflexibilidade, preconceito e falta de diálogo, e revelam, tal como ela destaca, o ceticismo diante da diversidade e da mudança. Inferimos, então, que a jornada universitária de Alice é duplamente dificultada: por suas dificuldades e condições peculiares de aprendizagem, que exigem elevada auto-organização, disciplina e busca por meios de superação; e pela resistência dos professores em entender a dislexia como deficiência. A junção desses fatores faz com que a posição eu-deficiente permaneça em destaque (Df - d).

[...] Porque às vezes as necessidades estão a nível intelectual, é interior, não são visíveis a nível exterior. E eu acho que essas aí acabam por ser mais difíceis de trabalhar, porque as pessoas não entendem, não veem [...].

Há mais pessoas que aceitam do que pessoas que não aceitam. Mas o problema é que aquelas que não aceitam não conseguem fundamentar por que não aceitam, e é isso que causa a revolta. Não aceito porque não acredito, não aceito porque... porque... são justificações tão vagas!

Diante da resistência às diferenças, que Alice percebe como a incapacidade de entender e ver de seus professores, interpretamos que a dislexia, diferentemente de outras deficiências e síndromes, que são observáveis, a olho nu, é invisível. E, por se manifestar de modos distintos, 
não é reconhecida pelos professores como deficiência, a menos que haja um laudo para comprovar.

Quer pela situação peculiar de uma diferença não identificável no fenótipo, quer pelas representações sociais que atribuem aos diferentes um lugar de menos-valia, temos assistido a situações difíceis, como aquela relatada por Alice (Dias, 2014; Ressureição, 2015). E comumente, como ela destaca, com justificativas "vagas". A condição de diferença aparece da seguinte forma na narrativa:

[...] não veem a diferença marcada na nossa cara, mas há diferenças. Aliás, há diferenças em todos nós.

Há professores até que, após receber isso [o documento em que constam as adaptações a serem feitas e os direitos do estudante], perguntam quem é o aluno, e eu penso, esses sim são professores, não é? Nos chamam à parte e nos perguntam o que vai precisar, que ajuda vai precisar, se um teste à parte, uma avaliação diferente... Dão-nos essas possibilidades. Eu, por acaso, nunca quis. Preferi sempre fazer como os outros. Nunca aceitei fazer um teste diferente, apropriado para mim, optei fazer exatamente como os outros, apenas faço no computador por causa da revisão gramatical, simplesmente, mas há de tudo.

Eu acho que todos os professores deviam ter uma formação específica para lidar com a deficiência. Porque se nós não soubermos lidar com a deficiência, nós não vamos conseguir dar aulas. E, se não soubermos lidar com a diferença, também não.

Ao expor os significados em torno da diferença que vivencia na universidade, conseguimos perceber que Alice os associa a condições de desvantagem. Alice inicia a fala na defesa da diferença como condição humana, a qual está “em todos nós”. Já no trecho seguinte, nega a ideia da diferença, ao afirmar que "nunca aceitei fazer um teste diferente", tentando se aproximar das condições oferecidas aos demais e, assim, não ser excluída. Destacamos da fala de Alice a importância da oferta de condições qualitativamente diferentes (por exemplo, introduzir o uso do computador nas provas e atividades avaliativas), a fim de oferecer condições quantitativamente equânimes de atividade (avaliação, por exemplo). Cremos que a 
questão está diretamente relacionada à formação docente, que é central para a inclusão ${ }^{27}$. Mesmo na alternância dos significados, predomina a posição eu-diferente em relação à sua ambivalente eu-deficiente ( $\mathrm{df}-\mathrm{D})$.

É a alternância dinâmica e negociada dos significados que vai constituindo posições identitárias diferentes e ambivalentes, suscitadas pelo indivíduo quando narra sua autobiografia. Com isso, identificamos indícios dos processos de auto-organização e mecanismos de compensação acionados diante dos novos desafios da experiência universitária. Ao ser questionada sobre suas perspectivas futuras, Alice conta:

dentro das minhas possibilidades, na minha formação, não vejo nenhuma. Não há. Vou ser das últimas na fila nacional e não há hipótese de conseguir atuar. Tem muita gente na minha frente, quem tem maior nota e experiência. Mas não nos dão a hipótese de ter experiência.

Mas os meus estudos para a profissão agora não dá para seguir. Eu vejo que me formo para ser melhor pessoa, mas a nível profissional, não.

Alice expressa desânimo perante as possibilidades de ocupar um espaço no mercado de trabalho compatível com sua formação de nível superior. Ela antecipa o possível impacto do “estreitamento de oportunidades" em sua vida. A dislexia, somada às dificuldades acadêmicas e às incompreensões por parte de alguns professores, afetou seu desempenho ao longo do ensino superior, o que resultou num conceito final considerado regular. Ela antecipa que a nota final de curso trará dificuldades para ocupar uma vaga como professora regente, dado o sistema de seleção vigente no país. Ela menciona também a falta de experiência profissional como dificultador de sua inserção profissional e opina sobre a insuficiência das iniciativas que ofereçam aos jovens oportunidades significativas de prática profissional. Pelos significados

\footnotetext{
${ }^{27}$ Sobre a importância da formação docente, ler mais na seção de discussão dos resultados.
} 
que se organizam com função prospectiva na vida de Alice, inferimos que ela prevê uma trajetória marcada pela posição eu-deficiente.

\subsection{Aproximações entre os casos: compreensões sobre a deficiência}

A aproximação entre o caso de João e os demais se relaciona à compreensão da deficiência como uma condição de desenvolvimento que, ao emergir na vida do sujeito, impulsiona sua auto-organização. Permite, ainda, crer que a ocorrência da deficiência em determinadas situações e/ou momentos da vida tende a ser assimilada pelo indivíduo de forma que, embora represente um marcador significativo, não gera impedimentos; tende a ser incorporada à subjetividade.

O caso de Maria tem em comum com os demais a compreensão da deficiência como fenômeno complexo, de natureza pessoal e social. A natureza pessoal se pauta na diferenciação do fenômeno de indivíduo para indivíduo e ao longo da vida; a natureza social se justifica por se materializar na relação com a sociedade. Outro aspecto em comum entre os casos relaciona-se ao esforço dos estudantes em tornar a experiência universitária exitosa. Para isso, Maria e os demais estudantes buscam alternativas capazes de (re)organizar e (re)configurar as vivências em torno da formação acadêmica, a fim de concluir seus cursos.

A possibilidade de aproximação entre o caso de Alice e os demais está apoiada na compreensão de que, quanto mais conhecimento o indivíduo possuir sobre si e suas demandas, mais favorecidos serão os processos de inclusão e as possibilidades de êxito. Entender as condições de funcionamento do sujeito permite acionar os mecanismos adequados de compensação e, assim, diminuir os impactos que convertem a dificuldade em deficiência. 


\section{DisCUSSÃo dOS RESULTADOS}

Neste capítulo, discutimos informações construídas ao longo do estudo e apontamos nossas reflexões sobre elas. O tema, da forma como o abordamos, gerou uma gama de informações sobre a experiência acadêmica dos estudantes com deficiência, o que possibilitou criar indicadores para práticas inclusivas na universidade e, ainda, traçar perspectivas analíticas do desenvolvimento adulto.

\subsection{Trajetórias de estudantes com deficiência na universidade: Proposição de indicadores para a ação}

Na revisão da literatura, foram explorados inicialmente os temas da deficiência (Dias, 2004, 2014; Goffman, 1988; Gugel, 2007; Miranda, 2003; Valle \& Connor, 2014), inclusão (Anache, 2007; Mantoan, 2008; Mitler, 2003; Mazzota, 1996; Sampaio, 2010; Sassaki, 2004), ensino superior (Antunes \& Faria, 2013; Coulon, 2008; Freitas, 2011; Marinho-Araújo, 2009, 2011; Martins, 2002; Ressurreição, 2013; Sguissardi, 2011; Zago, 2011). Em seguida, ao articular tais temas com o desenvolvimento humano, apresentamos os conceitos de psicologia cultural nas perspectivas semiótico-cultural e dialógica (Valsiner, 2007, 2012; Zittoun, 2007, 2009), cultura (Kelman, 2010; Valsiner, 2012), significados (Valsiner, 2012), dialogismo (Bakhtin, 1997; Salgado \& Gonçalves, 2007; Souza \& Gomes, 2009; Vygotsky, 1989), desenvolvimento adulto (Andrade, 2010; Arnett, 2000; Brandão, Saraiva \& Matos, 2012), multiplicidade (Cunha, 2007), ambivalências (Abbey \& Valsiner, 2005) e auto-organização (Abbey \& Valsiner, 2005; Cunha, 2007). 
Esses temas foram importantes na compreensão do fenômeno em estudo e permitiram a proposição de indicadores para a inclusão na universidade. Na perspectiva idiográfica, sentimos a necessidade de propor os conceitos de esferas da subjetividade atuando como figura e fundo, como forma de explicar a dinâmica de significação dos processos de desenvolvimento experimentados pelos estudantes. Então, num enfoque mais voltado aos processos de desenvolvimento e às experiências subjetivas, expomos nossa contribuição ao estudo dos processos de desenvolvimento humano adulto, com base nas proposições que formulamos.

De forma geral, a imersão no tema e o processo de construção da pesquisa apontam para a relevância de ampliar a visibilidade dos processos inclusivos na universidade. Percebemos, por meio das experiências narradas pelos estudantes, os impasses, os apoios recebidos, os obstáculos enfrentados, mas também as experiências de superação. Assim, com o intuito de que o estudo apresente as formas pelas quais os estudantes atribuem significado à experiência universitária e a si mesmos no processo, discutiremos os achados de duas formas complementares. De início, proporemos indicadores para práticas mais inclusivas na universidade. Vemos isso como uma forma de canalizar as vozes dos estudantes participantes do estudo para a orientação das práticas inclusivas na universidade, numa perspectiva mais ampla.

A partir da reflexão, interessa-nos destacar que o desenvolvimento se dá em meio a uma variedade de possibilidades de significados. Nossas experiências de desenvolvimento têm como base a dinâmica de negociação entre significados, que vão se constituindo e criando alternativas tanto para o vivido quanto para o futuro. São essas experiências que apoiam a construção da trajetória do indivíduo, e pela multiplicidade, pela novidade que tende a emergir ao longo da vida, apoiamos nossa concepção de desenvolvimento humano, escapando a 
conceituações deterministas. Passamos a apresentar o primeiro enfoque: os indicadores para a qualificação da inclusão em suas múltiplas práticas na universidade, à luz do olhar dos participantes: estudantes e pesquisadora.

\subsubsection{As vozes dos estudantes: indicadores para práticas mais inclusivas na universidade}

As narrativas dos estudantes nos informam sobre seus processos de desenvolvimento social e subjetivo. É fato considerar o potencial que a experiência universitária tem para impulsionar o desenvolvimento do jovem ou adulto, agregando à sua experiência de vida novas possibilidades. Compreendemos que a experiência universitária é ainda mais desencadeadora de processos que resultam em desenvolvimento no caso dos jovens ou adultos com deficiência, em virtude da carga maior de respostas a serem geradas à meritocracia estabelecida na universidade. Os valores meritocráticos exigem deles, de acordo com as condições individuais, maiores esforços na realização de determinadas atividades, a fim de corresponderem adequadamente ao esperado. E, em razão disso, desafiam-nos cotidianamente a superar barreiras, sejam elas materiais (deslocar-se e utilizar os espaços, acessar e adequar recursos pedagógicos), sejam elas atitudinais (contornar situações de preconceito, discriminação).

Para além do alto desempenho esperado dos estudantes com deficiência como universitários, soma-se às expectativas a superação de desafios colocados pela compreensão equivocada da deficiência, em termos de incapacidade, limitação, dificuldade. Com isso, o

estudante com deficiência na universidade se vê duplamente desafiado: a ter sucesso acadêmico, dada a exigência meritocrática, e a comprovar sua eficiência e capacidade diante de padrões normativos. 
Considerando que os estudantes participantes da pesquisa têm respondido a esse duplo desafio, muitas vezes com dificuldades, buscamos extrair de seus relatos nas entrevistas que indicadores podem contribuir para que a universidade se torne um espaço plenamente inclusivo. O intuito aqui é explorar os desdobramentos dos posicionamentos dos estudantes que apontam para mudanças a serem implementadas nas universidades, no âmbito da gestão, da política universitária, além de aspectos propriamente pedagógicos.

Com isso, emerge como ponto de discussão a tensão entre a meritocracia e os direitos humanos na cultura universitária. A ideia de mérito é um desafio aos estudantes que precisam, a fim de se inserir no espaço universitário e desfrutar de aceitação por parte dos professores, se submeterem às condições impostas, ainda que isso represente a colocação de uma barreira ou, ainda, demande uma mudança radical na trajetória pela impossibilidade de responder como esperado. A situação vivenciada por Maria é elucidativa, quando destaca que, apesar de seus esforços para cumprir com as demandas e expectativas estabelecidas aos estudantes, teve de mudar de curso, quando as oportunidades oferecidas (na concepção dela) não permitiram mais corresponder ao esperado. Em situações como essa, a meritocracia se contrapõe à cultura de direitos humanos com equidade de oportunidades na universidade. Com isso, vemos como necessária a reflexão sobre valores que servem de barreiras a uma cultura de direitos humanos nesse ambiente, uma vez que os estudantes com deficiência são objeto de resistências e preconceitos similares a outras minorias étnico-raciais, religiosas e de gênero.

Na exposição dos indicadores gerados, elencamos como destaques: a formação docente para a inclusão; a ação dos sistemas de apoio institucional; a criação de políticas de inclusão na universidade; e a importância dos pares nas práticas estudantis. 


\subsubsection{A formação docente para a inclusão}

O debate sobre os desafios para a inclusão no cenário universitário, do ponto de vista quer dos estudantes, quer dos sistemas de apoio institucionais, suscita como questão central investimentos que possibilitem a adequada formação docente para a atuação em contextos educacionais comprometidos com a inclusão. A formação deve integrar elementos gerais, relacionados à ética da inclusão e à cultura de direitos humanos, aspectos legais e aspectos teóricos específicos (sobre as deficiências e as pessoas com deficiência), metodológicos e técnicos da atuação pedagógica.

Em grande parte das vezes que mencionaram o relacionamento com professores, os estudantes reportaram-se a dificuldades, inflexibilidades e incompreensões. Destacamos os relatos de Alice, Emília, João e Maria, que relataram impasses com professores - por exemplo, negação de acesso a materiais para estudo e resistência em mudar de sala para favorecer o aluno que, pela deficiência auditiva, não consegue acompanhar as aulas ao lado de uma sala de ensaio musical, ou ainda que, pela deficiência física, não acessa com autonomia as salas de aula no subsolo da universidade. A situação sugere a necessidade de investimento em formação docente para a inclusão.

Com as reformas no curso de pedagogia que se seguiram à Lei de Diretrizes e Bases da Educação Nacional, a LDB (Lei n. ${ }^{0}$ 9.394/1996), a partir de 1997, desapareceram dos cursos as habilitações anteriores para focar na formação de docentes para a educação infantil e os anos iniciais. A criação de modelos com estrutura mais flexível, com adaptações às demandas de mercado, acabou tornando mais generalista a formação, sucumbindo a formação específica necessária para se portar diante de diferentes desafios do ensino, inclusive o de lidar com contextos inclusivos. O incremento às políticas de inclusão no país, a partir de 2003 , trouxe a 
temática de volta aos cursos (Saviani, 2005). No que se refere à formação de professores do ensino superior, crítica semelhante se pode fazer aos mestrados acadêmicos, cujo foco incide na formação de pesquisadores, deixando de fora a preocupação com a formação do mestre e os desafios que ele enfrenta no cotidiano da sala de aula, como a inclusão.

A formação, seja ela de caráter inicial ou continuada, pode favorecer o desenvolvimento de ações inclusivas mais exitosas na universidade. Emerge a necessidade de aproximar os docentes da temática da inclusão, sensibilizando-os ao atendimento às especificidades dos estudantes com deficiência e às adaptações necessárias a sua inserção e participação nas atividades acadêmicas.

Entendemos que as ações para a formação podem se dar por duas vias: numa forma mais generalista, no conjunto das ações da universidade, e com iniciativas mais específicas, ligadas às demandas e singularidades dos indivíduos para a inclusão. Nosso estudo apontou que modelos generalistas de inclusão tendem a não atender significativamente aos alunos, uma vez que os processos de desenvolvimento são singulares, portanto, procedimentos padronizados não são aplicáveis a todos. Nesse sentido, o relato de João destacou a importância da existência de um tutor como meio de compensar suas dificuldades e, assim, incluir-se nas aulas. A fala de Alice, por sua vez, apontou o uso do computador como meio para participar das atividades. Os exemplos dos estudantes demonstram a impossibilidade de estabelecer uma generalidade nos serviços de apoio, reforçando o caráter singular e individualizado do atendimento às demandas.

As ações a serem desenvolvidas pela universidade numa perspectiva mais ampla se referem a trabalhos de sensibilização e aceitação das diferenças: incremento das campanhas de conscientização, adequação e acessibilidade dos espaços e acesso aos serviços (por exemplo, biblioteca e restaurante), estabelecimento de fóruns para discussão e encaminhamento de 
demandas de estudantes, formação docente em serviço. Esses são importantes desafios à ampliação de propostas favorecedoras de inclusão.

Como o espaço universitário é definido por competência e mérito, a inclusão no ensino superior é prejudicada por preconceitos, crenças e valores sociais e pessoais de uma sociedade baseada em modelos de normalidade e competição altamente excludentes (Dias \& Lopes de Oliveira, 2013; Mantoan, 2013; Sousa Santos, 2005). A ressignificação das questões que, de alguma forma, subsidiam práticas excludentes é um compromisso a ser assumido pela universidade.

Conhecer o estudante e partilhar com ele as demandas para a inclusão, realizar estudos e reflexões sobre essa temática e sobre as especificidades de cada deficiência (características, formas de compensação, adaptações curriculares) tendem a tornar a atuação do professor mais eficaz. Para as ações, o apoio e o acompanhamento dos sistemas de inclusão da universidade se fazem primordiais, seja como suporte aos estudos e reflexões, seja como ligação entre as especificidades do aluno e as necessidades do professor. A inclusão exige um esforço complexo para a mudança, que, em uma de suas dimensões, tem como fator-chave a formação dos professores. A qualificação profissional beneficia os processos de inclusão, por superar a barreira do despreparo e desconhecimento.

\subsubsection{A ação dos sistemas de apoio}

Os serviços de apoio na universidade são considerados pelos estudantes como mecanismos importantes para a permanência. As universidades investigadas têm uma situação peculiar e excepcional em relação às instituições de ensino superior em geral, que é o fato de serem dotadas de um setor encarregado de implementar ações sistêmicas no apoio ao 
estudante com deficiência. Além disso, a depender das características da equipe, dos recursos e do histórico institucional, os serviços podem se organizar de forma a favorecer algumas ações em detrimento de outras.

Com isso, emerge como indicador de práticas inclusivas na universidade a disponibilização de serviços de apoio especializados e significativos, capazes de prover acompanhamento e suporte aos indivíduos que demandam ajudas específicas para exercer seu “ofício de estudante" (Coulon, 2008). As universidades visitadas apresentam diferentes desafios a serem superados. Em uma das universidades portuguesas, um destaque foi a baixa adesão dos professores e demais servidores às ações para a inclusão. Em outra universidade de Portugal, o prédio antigo e tombado faz com que os problemas se concentrem na adaptação e acessibilidade. Lá os estudantes têm mais dificuldades para se deslocar, pois faltam recursos e adaptações que gerem mobilidade. A terceira, que possui o serviço de apoio mais formalizado, enfrenta problemas financeiros, o que faz com que as ações e os atendimentos sejam restritos aos escassos recursos e à iniciativa de voluntários.

No Brasil, a realidade é de um serviço que ainda não possui autonomia na universidade e é submetido à prefeitura do campus, o que torna limitado o alcance das ações. Somam-se aos desafios as adaptações para a acessibilidade em prédios do campus mais antigos e tombados. Em comum nas quatro universidades, percebemos a existência de uma cultura meritocrática, as atitudes de preconceito e as iniciativas de superação dos estudantes. Para a garantia de condições, ganha destaque a importância do respeito, bem como o suporte adequado nas necessidades e o incentivo à autonomia do sujeito, na condição de estudante do ensino superior, cidadão e, ainda, futuro profissional.

Vimos que serviços organizados para apoiar a comunicação entre estudantes e professores podem promover experiências mais exitosas de inclusão, tendo como base o 
respeito à diferença e o diálogo, e como objetivo, estimular a autonomia do estudante. Exemplo de iniciativas avaliadas como exitosas pelos participantes é a tutoria especial implementada na universidade brasileira, a que João teve acesso, e ainda a mediação com os professores, conforme destacado pela participante portuguesa Alice. Dessas oportunidades, advêm vivências mais positivas, capazes de empoderar o estudante com deficiência no cenário universitário, notadamente mais exigente e complexo que os contextos educacionais anteriores (Antunes \& Faria, 2013; Coulon, 2008; Fernandes \& Almeida, 2007).

\subsubsection{A criação de políticas de inclusão}

É preciso haver apreciação e intervenção sistêmica da universidade na identificação das necessidades de inclusão, que resulte em plano para nortear as ações e iniciativas. Assim, torna-se possível às universidades prever, em seus orçamentos, as demandas do corpo discente e docente, e as medidas a serem implementadas a cada momento. Trabalhos dessa natureza podem converter a universidade — espaço meritocrático (e em dadas situações excludente) — em lócus cada vez mais inclusivo. Dessa forma, tornar a universidade inclusiva compreende um conjunto de ações articuladas e orientadas que possibilitem a criação de um sistema inclusivo, avançando na lógica vigente de adoção de ações e medidas isoladas.

Um indicador que se alinha com a preocupação de criar um sistema inclusivo perpassa pela adequação dos recursos de acessibilidade e mobilidade. Como destacado por Maria, Pedro e Rita, os recursos de acessibilidade e mobilidade na universidade se fazem essenciais às pessoas com condições motoras diferenciadas. $\mathrm{O}$ atendimento às demandas de mobilidade pode apoiar o estudante em seu processo de integração à universidade (Abreu, Antunes \& Almeida, 2012; Antunes \& Faria, 2013). 
Vimos inadequações nas universidades, e ouvimos dos estudantes reclamações sobre elas. Há prédios com arquitetura pouco acessível ou pouco segura (a falta de barras de segurança em rampas e escadas, destacada por Maria); e indisponibilidade de recursos de acessibilidade (como rampas, elevadores, piso tátil ou barras de apoio, percebidas por Emília e Pedro) em alguns espaços do campus — restaurante, cantina, prédios de aula, anfiteatros.

Também se relataram problemas em áreas externas e redondezas: estacionamentos em precárias condições de conservação, o que faz com que o piso represente uma barreira no deslocamento; a grande distância entre faixas de pedestres, que gera risco para a locomoção entre diferentes espaços (para Maria e Rita, estudantes com baixa visão e cegueira, respectivamente); e, ainda, calçadas irregulares e defeituosas que interligam os espaços da universidade e que impõem mais cuidados e dificuldades a todos, como bem relatou Emília, que já sofreu uma queda da cadeira de rodas na calçada do campus.

Cremos que a preocupação com o deslocamento livre e seguro nos espaços da universidade constitui um indicador de ação a ser observado. O exercício de ocupar e deslocar-se entre os espaços com segurança e adequadas condições precisa ser um compromisso a ser assumido com todos os usuários. Alinhado ainda com o fundamento de criação de uma cultura inclusiva na universidade, um indicador que ganha destaque é a promoção de atitudes de acolhimento aos estudantes com deficiência por seus pares (Antunes \& Faria, 2013; Fernandes, Almeida \& Mourão, 2007).

\subsubsection{A importância dos pares nas práticas estudantis}

Os estudantes com deficiência identificam os colegas de turma como uma alteridade com que se relacionam positivamente, aqueles de quem obtêm apoio nas diversas situações de 
vida acadêmica. Esse aspecto foi ressaltado nas falas de Alice, João, Maria e Rita, com destaque para atitudes de aceitação, apoio nas atividades de estudo, empréstimo de materiais, trabalhos em grupo e ajuda na organização de tarefas. Alice e Maria chegaram a mencionar que se sentem mais apoiadas pelos colegas, a quem recorrem nas dificuldades, do que pelos sistemas de inclusão da universidade. Consideramos que a interação e o clima de aceitação favorecem a familiarização, a proximidade e o estabelecimento de relações positivas entre os estudantes, bem como os processos de socialização e desenvolvimento dos jovens.

De modo geral, o espaço da universidade atua como um marcador social, acadêmico e profissional na vida dos jovens e adultos que dela fazem parte. Na universidade, os estudantes ampliam as redes sociais e as esferas de experiência coletiva, uma dimensão da qual os estudantes com deficiência podem ser alijados. Quando estes encontram experiências sociais e acadêmicas ampliadas, bem como relações mais éticas e igualitárias, suas oportunidades de desenvolvimento aumentam. Cabe-nos ainda refletir sobre a importância de ampliação dos círculos de relacionamento dos estudantes, fazendo com que as experiências consideradas positivas possam ocorrer também na interação com professores, técnicos e gestores.

Ainda na crítica dos temas suscitados pelo estudo, temos o debate sobre a tensão entre reconhecimento de direitos e financiamento de políticas inclusivas. Como apontado, a escassez de recursos para o suporte a ações inclusivas representa um empecilho aos sistemas de apoio. Entendemos que toda inovação, por mais que reconhecida como necessária, esbarra na definição da fonte de recursos. Como vimos até aqui, muitos são os desafios e os indicadores para a construção de sistemas mais eficientes de apoio aos estudantes na universidade. 


\subsection{Trajetórias de estudantes com deficiência na universidade: $O$ fenômeno do desenvolvimento}

Quando nos voltamos aos três casos analisados sob uma perspectiva idiográfica, as trajetórias de João, Maria e Alice, refletimos sobre os processos de desenvolvimento por eles experienciados. A seleção desses casos teve um critério: reportar-se a experiências de dificuldade, menos-valia, mas, em determinados momentos e circunstâncias, dar lugar a atitudes que rompem com a situação vigente e, por meio de um processo de transição, reorganizam o indivíduo inter e intrasubjetivamente, permitindo construir uma trajetória de superação das dificuldades e barreiras.

Esses relatos nos permitem compreender a deficiência como fenômeno dinâmico e relacional. Com isso, destacamos que a deficiência está em desenvolvimento. O impedimento físico, sensorial ou mental que nela se expressa representa uma dimensão importante do desenvolvimento global, ou seja, um marcador que é incorporado à vida, (re)organiza a subjetividade e canaliza possibilidades de trajetórias do indivíduo. Sabemos que a presença de uma deficiência pode representar uma dificuldade, maior ou menor, para a realização de um rol de atividades, mas não para uma multiplicidade de outras. Como os caminhos de desenvolvimento são múltiplos, as dificuldades não se constituirão impedimentos se o foco das mediações visar as possibilidades e não as dificuldades. A deficiência existe e se associa à vida, mas como uma face do desenvolvimento, não respondendo pela totalidade da pessoa.

Nos três casos, tivemos contato com histórias que revelam a capacidade dos participantes de lidar com os desafios do dia a dia de forma dialógica. Nas respostas cotidianas a tais implicações, estão contidas, além das demandas do presente (constituir-se como 
estudante de ensino superior), aquilo que se espera alcançar no futuro (concluir o ensino superior e inserir-se no mercado de trabalho).

Para isso, elencamos nas narrativas a dinâmica da trajetória em suas ambivalências. Por meio de uma perspectiva semiótico-cultural e dialógica, os significados em tensão foram organizando e compondo a trajetória de cada um, o que nos proporcionou perceber como o desenvolvimento esteve relacionado a momentos de ruptura, transição. Foi possível, sobretudo, compreender como tais eventos destacaram a importância da (re)construção de significados mediados pela alteridade. Vimos que, a cada novo desafio, um conjunto de significados foi organizado pelos estudantes, em meio a múltiplas possibilidades de resposta. Com isso, a proposição se mostra representativa da dinâmica entre as posições na autoorganização dos sujeitos (Cunha, 2007), do caráter dialógico e múltiplo em possibilidades (Abbey \& Valsiner, 2005), que se move de acordo com as negociações estabelecidas com o contexto e a alteridade (Bastos, 2011; Valsiner, 2012). As trocas (simbólicas e de materiais) acabam por promover a emergência de signos como figura, enquanto outros permanecem como fundo, compondo o campo das escolhas não realizadas ou enfraquecidas, ainda que temporariamente. Assim, entendemos que os significados se organizam em posicionamentos e por sua vez, compõem esferas da subjetividade do sujeito. Lotman (1996) destaca o conceito de semiosfera, como o campo de significados que envolvem o sujeito, em torno do qual ele organiza e interage com o contexto em que se insere. Algumas mais fluidas e sujeitas a mudanças mais facilmente, enquanto outras, mais enraizadas e portanto, dependentes de eventos de ruptura mais significativos para se alterarem. algumas esferas, da subjetividade permanecem como possibilidade de assumir a posição de figura num momento posterior, pela emergência de novos significados e/ou pela ressignificação do vivido. Destacamos que a proposta adota o caráter dinâmico, dialógico e aberto dos processos de desenvolvimento. 
Ao abordarmos as reações particulares dos estudantes, inferimos que o fenômeno da inclusão, em meio a tensões e ambivalências, gera uma multiplicidade de significados, que são acionados pelo indivíduo para responder às incertezas e, ao mesmo tempo, mostrar-se compatível com a necessidade de manter a continuidade no sentido de si e a auto-organização (Bastos, 2011; Cunha, 2007). Diante dessa dinâmica de emergência de infinitas possibilidades e significados nos eventos que vão delineando o desenvolvimento, chegamos ao que pensamos ser uma contribuição relevante do trabalho: os conceitos de esferas da subjetividade.

Defendendo a impossibilidade de reduzir a dinamicidade do desenvolvimento a uma única sequência linear de eventos, identificamos que, a cada corte na linha biográfica de uma pessoa, ficamos diante de uma trajetória, organizada em torno de esferas da subjetividade que ocupam o lugar de figura, definida em termos de posicionamentos e significados dominantes, a qual é permeada por infinitas esferas da subjetividade que atuam, na situação, como fundo. Estas últimas são constituídas por vivências passadas, memórias, imagens, signos e afetos, mais ou menos organizados, que podem vir à tona e servir de matéria-prima para fomentar a reorganização psicológica da pessoa, diante de eventos e dinâmicas disruptivas da autoorganização pregressa. A proposição das esferas se relacionando aos posicionamentos e se alternando como figura e fundo na subjetividade, representa meio de interpretação para os fenômenos vividos, buscando destacar o caráter múltiplo, reconstrutivo e não determinístico do desenvolvimento humano. 
Figura 2: Esferas da subjetividade como figura e fundo nos processos de significação

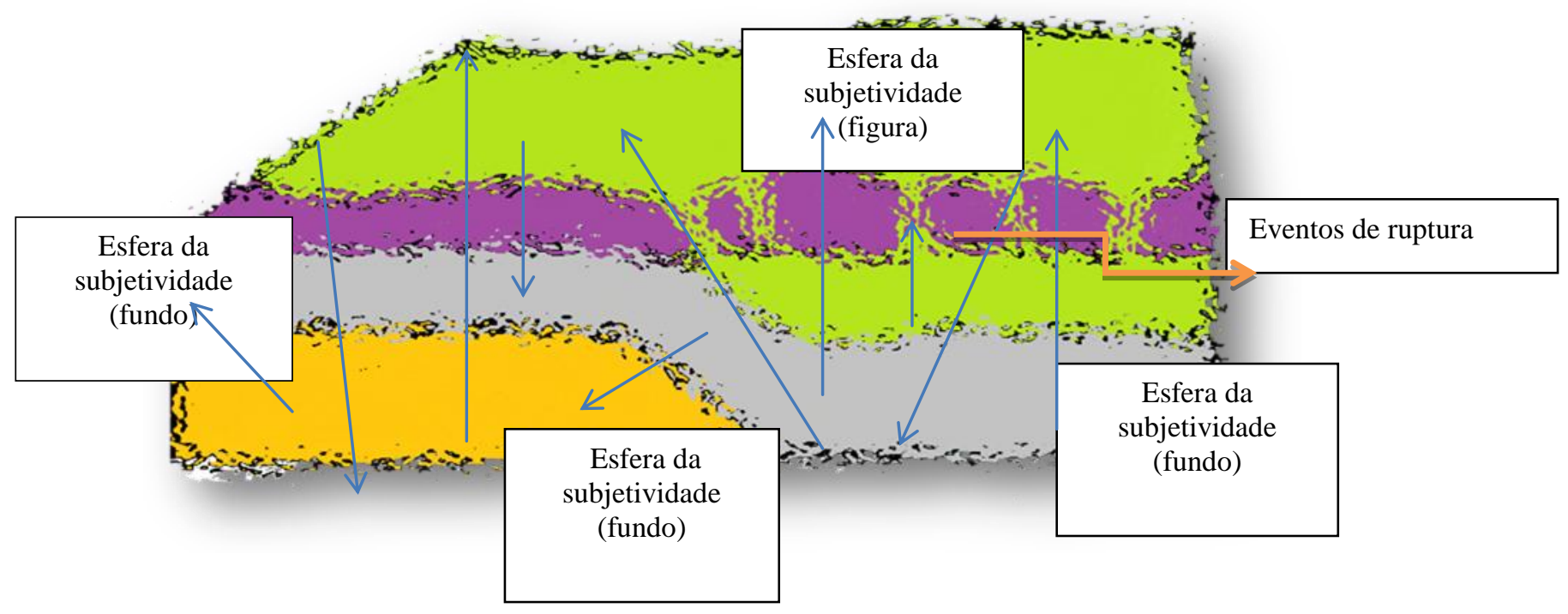

Fonte: Elaboração da pesquisadora

A figura acima representa os significados que compõem a dinâmica das esferas da subjetividade, ora como figura e ora como fundo. A auto-organização dos sujeitos é resultado da negociação entre uma série de posições em ambivalência (Abbey \& Valsiner, 2005; Cunha, 2007). Os eventos de ruptura, que entram no sistema pela emergência de novos significados e/ou pela ressignificação do vivido, acabam por promover a emergência de alguns signos como figura, enquanto outros permanecem como fundo, compondo o campo das escolhas não realizadas no momento. Importa destacar que, pela dinamicidade e multiplicidade de significados que construímos nas experiências, estamos sempre diante de infinitas trajetóriasfundo, que têm como base nossas vivências passadas, memórias, imagens, signos e afetos. O que se constitui como fundo num momento, diante de um evento com a força de romper com a auto-organização vigente, pode ocupar a posição de figura no momento seguinte e assim, 
alternarem-se inúmeras vezes, ou mesmo desaparecer, dando espaço a novas posições. As experiências dos estudantes João, Maria e Alice ilustram nossa proposição.

Na trajetória de João, fomos desafiados a compreender a deficiência como fenômeno emergente na fase adulta (em torno dos 55 anos) e o papel que ela desempenhou como vetor de reorganização da subjetividade - o estudante passou quase repentinamente da condição de excelente ouvinte à de surdo. Nesse caso, inferimos que a trajetória estudantil esteve tensionada entre os significados estudante $x$ trabalhador e eficiente $x$ deficiente.

Quando consideramos a trajetória de Maria, o desafio é reconhecer a deficiência como fenômeno em desenvolvimento e, desse modo, atuando como uma dimensão central da vida da participante no momento da pesquisa. O agravamento da perda visual e o risco iminente de cegueira total tornam a deficiência um significado preponderante na dinâmica de (re)configuração subjetiva de Maria, nos anos finais do ensino superior. Sua trajetória esteve tensionada entre os significados eficiente $x$ inconveniente e, ainda, eficiente $x$ deficiente. Os signos em tensão exigem de Maria esforços para perseguir um ideal de autonomia e vida independente, que ela almeja conquistar por meio de sua formação universitária.

Por fim tomando o caso de Alice, o nosso desafio se centrou na compreensão da deficiência como fenômeno (inicialmente) desconhecido e os impactos do diagnóstico para explicar aquilo que não é visível. Dias (2014) em tese desenvolvida no Instituto de Psicologia da Universidade de Brasília (UnB) intitulada "A quem serve o diagnóstico de deficiência intelectual? Um estudo do desenvolvimento adulto na perspectiva da Psicologia Dialógica” problematiza os processos diagnósticos de deficiência que decorrem, em grande parte, de aspectos psicométricos que mais destacam "a crença na incapacidade e impossibilidade e agência dessas pessoas" (Dias, 2014,p.10). O estudo destaca também o caráter dialógico que posiciona o sujeito, por um lado como deficiente, pouco inteligente, ao mesmo tempo que, por 
outro lado, o adjetiva como capaz, competente, inteligente. Em suma, encontrou indicadores de que um diagnóstico (na pesquisa em tela, de deficiência intelectual) não define trajetórias de insucesso e incapacidade. A pesquisa exemplifica como a manifestação da deficiência é sempre um fenômeno relacional, resultante das formas como a sociedade impõe limites e dificuldades aos considerados diferentes (Goffman, 1988; Valle \&Connor, 2014; Vygotsky, 1995).

Munidos da crença de que o diagnóstico de uma deficiência não é limitador de uma trajetória, entendemos que os processos de diagnóstico precisam responder de forma mais qualificada às especificidades do sujeito e as várias possibilidades de desenvolvimento. Ao contrário de um rótulo, o diagnóstico pode representar oportunidade de autoconhecimento, identificação de potencialidades e formas de funcionamento inter e intrasubjetivos.

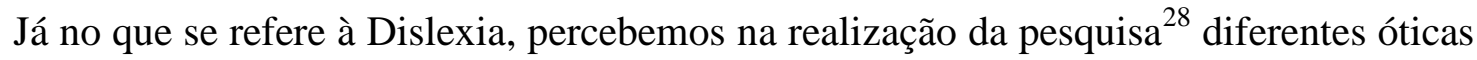
que enquadram. Por um lado, é definida como uma dificuldade de aprendizagem, mais especificamente um distúrbio de aprendizagem e, portanto, uma Necessidade Educacional Especial (NEE) que se relaciona à presença de dificuldades significativas na linguagem receptiva e expressiva, oral ou escrita (Shaywitz, 2006; Silva, 2009; Correia, 2013). Por sua vez, a Organização da Mundial de Saúde (OMS) define deficiência como "perda ou anormalidade de uma estrutura ou função psicológica, fisiológica ou anatômica que gere incapacidade para o desempenho de atividade, dentro do padrão considerado normal para o ser humano" (OMS, 2011). Essa definição tem apoiado outro viés de compreensão, e nas práticas de inclusão na universidade, os sujeitos têm sido classificados como alunos com deficiência,

\footnotetext{
${ }^{28}$ Referimo-nos à realização da pesquisa sobre Dislexia, feita durante a experiência do Doutorado Sanduíche (PDSE) em Portugal, em que diante da participação de Alice, que tem diagnóstico de Dislexia é identificada e se auto-identifica como deficiente questionamos ao setor responsável pela inclusão na universidade a origem dessa classificação.
} 
ao tomar a Dislexia como "anormalidade de uma estrutura ou função psicológica". Assim, o estudo abordou como deficiências todas as manifestações relacionadas às demandas dos estudantes com condições permanentes ou duradouras que limitam/modificam e/ou impedem a realização de determinadas atividades como esperado, coerentes com a concepção adotada pelos serviços de apoio visitados.

Temos ciência que o tema das definições e nomenclaturas referentes às deficiências e/ou necessidades educacionais especiais suscita debates e distintas compreensões. Entretanto, entendemos que, embora haja divergentes formas de designar as condições e peculiaridades dos indivíduos, fato é que tais condições impactam de alguma forma a auto-organização e também de os processos de desenvolvimento experenciados pelos indivíduos.

O valor de nossa proposição para o debate sobre o desenvolvimento humano destacou a compreensão de que os processos experienciados são sempre múltiplos em possibilidades e permitem a ressignificação do vivido diante de quaisquer circunstâncias. Além disso, ampliamos o entendimento da deficiência como fenômeno que, embora com forte carga semiótica, não é delimitador ou norteador, uma vez que o sujeito desfruta sempre de várias possibilidades de resposta e reconstrução da trajetória. 


\section{CONSIDERAÇões FINAIS}

Este estudo ampliou as possibilidades de compreensão do fenômeno da educação superior inclusiva, sob diferentes perspectivas. Pudemos entender melhor os sistemas de significados acerca de deficiência e inclusão, que permeiam o cotidiano das instituições de ensino investigadas, os quais foram acessados da perspectiva dos gestores dos serviços. Da mesma forma, dedicamos um esforço interpretativo ao fenômeno da inclusão, sob o enfoque das trajetórias de desenvolvimento de estudantes com deficiência, mediados pelas experiências subjetivas e institucionais no contexto da universidade. No entrecruzamento dessas duas dimensões (institucionais e subjetivas), propusemos indicadores para o aprimoramento das práticas inclusivas em contextos universitários.

Vimos que a matrícula de jovens que demandam atendimento inclusivo é crescente nas instituições de ensino superior; entretanto, a efetividade da inclusão ainda encontra barreiras, 
que buscamos melhor caracterizar no estudo. Emerge como um desafio para a universidade responder à demanda crescente dos estudantes com deficiência. Essa demanda tem justificado a criação de serviços de apoio à inclusão por parte das instituições de ensino superior — serviços esses que tendem a ter um papel de crescente importância, diante de uma universidade que se pretende heterogênea, plural e inclusiva.

Entendemos que promover a inclusão nesse nível de ensino representa um desafio, permeado por diversas dificuldades: a sensibilização da comunidade universitária; a desconstrução de crenças e preconceitos contra aqueles que são percebidos como dotados de uma capacidade "menor" de aprendizagem devido à deficiência; a desconstrução das autoimagens institucionais assentadas na meritocracia; o respeito às diferenças humanas; e o amplo envolvimento da comunidade acadêmica na ética da inclusão. Além da sensibilização dos atores e da luta contra os preconceitos e a desinformação, identifica-se ampla necessidade de adequar a formação docente, até questões ligadas aos custos das reformas e manutenção de equipamentos; e o desenvolvimento e a especialização dos serviços de apoio no espaço universitário.

Conhecer o que pensam e sentem os estudantes com deficiência em relação aos serviços e ao próprio contexto, bem como suas sugestões para melhorar as condições de inclusão e aproveitamento na universidade, é fundamental para ampliar e qualificar os serviços de apoio e aumentar as chances de sucesso acadêmico. Também é importante o acompanhamento processual dos estudantes com deficiências que demandam serviços específicos ou recursos técnicos nos serviços de apoio. A complexidade dos sistemas de significados que atravessam o cenário das universidades evidencia a necessidade de que, desde o momento da inscrição, sejam colocados à disposição dos estudantes meios que proporcionem familiarização com o ambiente e funcionamento, diminuindo angústias e 
barreiras, ao gerar expectativas positivas em relação ao ensino superior e a adoção de atitudes mais ativas perante os desafios dessa nova etapa de estudos. Esse apoio possibilitaria, ainda, o exercício da autonomia, entendida como relevante no ensino superior.

A proposição das trajetórias-figura e fundo representou o esforço de expor nossa compreensão sobre o fenômeno do desenvolvimento, em seu caráter múltiplo, indeterminado, com alta capacidade reorganizativa. Partilhamos da ideia de que, como processo dialógico perpassado por eventos de rupturas e transições, o desenvolvimento humano é fenômeno sempre inacabado, trazendo no tempo irreversível histórias e fatos do passado e antecipações de futuro.

As reflexões suscitadas no estudo se mostraram pertinentes e possibilitaram o contato com um recorte da realidade sobre a inclusão no ensino superior. Pretendemos, com a discussão, reforçar também a necessidade de iniciativas e políticas afirmativas direcionadas a pessoas com deficiência, num viés mais emancipatório e valorativo das potencialidades dos sujeitos. Os participantes da pesquisa são exemplos do exercício da autonomia.

Com isso, a pesquisa aponta para a necessidade de encontrar nas instituições de ensino um ambiente verdadeiramente acolhedor à diferença. Para tanto, emergem os desafios de promoção de um diálogo mais ativo entre universidades e mundo do trabalho no que se refere a questões que afetam de modo peculiar as pessoas com deficiência (evitando, no caso de Maria, a necessidade de mudança de curso); de maior abertura da universidade para o conhecimento acumulado sobre o tema em outros espaços sociais - como as escolas de educação básica, que, há 20 anos ou mais, vêm aprimorando metodologias e estratégias de inclusão; e, ao mesmo tempo, de maior comprometimento com a produção de conhecimentos relevantes para mudar sua própria realidade excludente. Assim, o espaço acadêmico assume um papel emancipador, crítico e participativo, superando modelos idealizados que tendem a 
segregar determinados grupos de estudantes, especialmente aqueles que podem ter alguma desvantagem, como no caso da deficiência.

Como o tema em estudo é complexo e multidimensional, temos ciência das limitações desta pesquisa. Temos convicção de que nenhum estudo consegue abordar os fenômenos da experiência humana em sua multiplicidade, mas, ao mesmo tempo, aquilo que apontamos como limitação pode ser canalizado como propulsor de novos questionamentos e pesquisas. Identificamos como limitações o número reduzido de participantes e de universidades pesquisadas, e ainda o fato de o estudo ter se concentrado na participação de estudantes com histórias que consideramos de sucesso. Embora saibamos das dificuldades enfrentadas pelos participantes cotidianamente, todos reportam histórias de superação e permanência na universidade. Entretanto, é possível que vários estudantes tenham desistido de cursar o ensino superior em razão das adversidades encontradas. Com o desenho adotado no presente estudo, não alcançamos esses estudantes.

Sugerimos, pela relevância da proposta, que a continuidade do estudo, ou ainda novas iniciativas de pesquisa, possam enfatizar a evasão na universidade por parte dos estudantes com deficiência. A ideia é conhecer as causas do fenômeno e, assim, fazer proposições que avancem na criação de uma universidade em que todos tenham a chance de concluir seus cursos. Estudos futuros podem ter foco em temáticas que emergiram aqui, como a formação docente e temas correlatos: as práticas de ensino e de avaliação, as relações entre professores e estudantes com deficiência, o apoio dos colegas como representação de uma alteridade positiva.

Enfim, por meio do estudo, foi possível compreender que a presença de estudantes com deficiência no ensino superior exige da universidade não apenas o reconhecimento de um direito, mas também uma iniciativa de romper com valores e normas que, velada ou 
abertamente, imprimem a esses sujeitos obstáculos e marcas segregadoras. Deixamos a cargo de Alice as palavras finais deste trabalho: "ninguém pode ensinar alguém sem ver que essa pessoa à frente é diferente e que a pessoa à frente nos é tão próxima, justamente por ser diferente de nós. E que é por sermos diferentes que podemos nos ensinar uns aos outros e podemos aprender uns com os outros". Desejamos que assim seja, em todos os espaços destinados ao ensino e à aprendizagem, especialmente na universidade. 


\section{REFERÊNCIAS}

Abenhaim, E. (2005). Os Caminhos da Inclusão: breve histórico. In: A. M. Machado (Ed.). Psicologia e Direitos Humanos: educação inclusiva, direitos humanos na escola (pp.39-54). São Paulo: Casa do Psicólogo.

Abbey, E. \& Valsiner, J. (2005). Emergencce of meanings through ambivalence. Forum: Qualitative Social Research. 6, (1), art.23.

Abreu, M., Antunes, A. P., \& Almeida, L. S. (2012). A Inclusão no Ensino Superior: Estudo exploratório numa Universidade Portuguesa. Revista da Educação Especial $e$ Reabilitação, 19, 107-120.

Albuquerque, A. P., \& Martínez, A. M (2012) . Inclusão escolar e subjetividade social da escola: relações e possibilidades. In: A.U Branco \& M. C. Lopes de Oliveira (Eds.). Diversidade e cultura da paz na escola: contribuições da perspectiva sociocultural (pp.185-212). Porto Alegre: Mediação.

Amado, J. (2013). Investigação Qualitativa em Educação. Coimbra: Imprensa da Universidade de Coimbra.

Anache, A. A. (2007). O psicólogo nas Redes de Serviços de Educação Especial: Desafios em face da inclusão. In A. M. Martínez (Ed.). Psicologia Escolar e Compromisso Social (pp. 115-134). Campinas, São Paulo: Alínea.

Anache, A. A. (2009). O psicólogo escolar e o processo de escolarização de pessoas com deficiência mental. In C. M. Marinho-Araújo (Ed.). Psicologia Escolar: novos cenários e contextos de pesquisa, formação e prática (pp. 221-244). Campinas (SP): Alínea.

Andrade, C. Y. (2010). Acesso ao ensino superior no Brasil: Equidade e desigualdade social. Revista Ensino Superior Unicamp,18- 27. 
Antunes, A. P., \&Faria, C. P. (2013). A universidade e a pessoa com necessidades especiais: estudo qualitativo sobre perceções de mudança social, institucional e pessoal. Indagatio Didactica, 5, (2), 475-488.

Aranha, M.S.F. (1995). Integração social do deficiente: análise conceitual e metodológica. Temas em Psicologia, 2, 63-70.

Arnett, J. J. (2000). Emerging adulthood: A theory of development from the late tens through the twenties. American Psychologist. 55, n. ${ }^{\circ}$ 5, 469-480.

Bakhtin, M. (1997). Estética da criação verbal. São Paulo: Martins Fontes.

Bamberg, M., Georgakopoulou, A. (2008). Mall stories a new perspective in narrative and identity analysis. Text \& Talk. Worcester, 28, (3), 377-396.

Bastos, A. C. S. (2011). Notes on the Trajectory Equifinality (TEM) Model, Poetic Motion and the Analysis of Autobiographical Narratives. Texto apresentado no Grupo de Trabalho da ANPEEP. São Paulo.

Bauer, M. W., \& Gaskell, G. (2012). Pesquisa qualitativa com texto, imagem e som: Um manual prático. Petrópolis: Vozes.

Bisinoto, C. \& Marinho-Araújo, C. M. (2014). Sucesso Acadêmico na Educação Superior: Contribuições da Psicologia Escolar. Revista E-Psi, 4(1), 28-46.

Branco, A. U. (2006). Crenças e práticas culturais: coconstrução e ontogênese de valores sociais. Pro-posições, Campinas, 17, p.139-155.

Branco, A. U., Pessina, L., Flores, A., \& Salomão, S. (2004). A sociocultural constructivist approach to metacomunication in child development. In: A.U. Branco \& J. Valsiner (Eds.). Metacomunication in human development (pp. 3-32). Greenwich, CT: Information Age Publishing Inc. 
Brandão, T., Saraiva, L., \& Matos, P. M. (2012). O prolongamento da transição para a idade adulta e o conceito de adultez emergente: Especificidades do contexto português e brasileiro. Análise Psicológica, 30, 301-313.

Brasil (1961). Lei n. ${ }^{o}$ 4.024, de 20 de dezembro de 1961. Fixa as Diretrizes e Bases da Educação Nacional. Brasília: MEC.

Brasil (1971). Lei n. ${ }^{o}$ 5.692/1971, de 11 de agosto de 1971. Aponta o direito dos excepcionais à educação, preferencialmente dentro do sistema geral de ensino.

Brasil (1988). Constituição da República Federativa do Brasil. Brasília: Senado Federal, Subsecretaria de Edições Técnicas.

Brasil. (1996). Lei . $^{\circ}$ 9394, de 20 de dezembro de 1996. Estabelece as diretrizes e bases da educação nacional. Brasília: MEC.

Brasil (1997). Parâmetros Curriculares Nacionais - Adaptações Curriculares. Institui as Diretrizes Curriculares Nacionais para a Educação Especial na Educação Básica.

Brasil. (1999). Decreto n. $^{\circ} 3.298$, de 20 de dezembro de 1999. Regulamenta a Lei n. ${ }^{\circ}$ 7.853, de 24 de outubro de 1989, dispõe sobre a Política Nacional para a Integração da Pessoa Portadora de Deficiência, consolida as normas de proteção, e dá outras providências. Brasília: Presidência da República.

Brasil (2001a). Lei n. ${ }^{o}$ 10.172, de 09 de janeiro de 2001. Aprova o Plano Nacional de Educação. Brasília: MEC.

Brasil (2001b). Decreto $n .^{o}$ 3.956/2001. Ratifica a Convenção Interamericana para a Eliminação de Todas as Formas de Discriminação.

Brasil (2001c). Resolução CNE/CEB n. ${ }^{o}$ 02/2001. Determina que os sistemas de ensino matriculem todos os alunos, cabendo à escola organizar-se para o atendimento aos 
educandos com necessidades educacionais especiais. Brasília: Conselho Nacional de Educação.

Brasil (2002a). Resolução CNE/CP n. ${ }^{o}$ 01/2002. Estabelece diretrizes para a formação de professores da educação básica, define que as IES devem prever em sua formação docente atenção e conhecimento às especificidades dos alunos com necessidades educacionais especiais. Brasília: Conselho Nacional de Educação.

Brasil (2002b). Lei n. ${ }^{o}$ 10.436/2002, de 24 de abril de 2002. Reconhece e Língua Brasileira de Sinais (LIBRAS), apoiando seu uso e difusão. Brasília: MEC

Brasil (2002c). Portaria $n^{o}$ 2.678/2002. Aprova diretrizes e normas para o uso, ensino, produção e difusão do sistema Braille. Brasília: MEC.

Brasil (2004). Decreto $n^{o}$ 5.296/2004. Estabelece normas e critérios para a promoção da acessibilidade às pessoas com deficiência ou mobilidade reduzida. Brasília: MEC

Brasil (2005). Lei n. ${ }^{o} 11.096$, de 13 de janeiro de 2005. Institui o Programa Universidade pata Todos - ProUni. Brasília: MEC.

Brasil (2005). Decreto $n .^{\circ}$ 5.626/2005. Dá acesso aos alunos surdos à escola, inclui a Libras como disciplina curricular, a formação e certificação de professor, intérprete e instrutor. Estabelece o ensino de língua portuguesa como segunda língua e a organização da educação bilíngue. Brasília: MEC

Brasil (2007). Decreto $n .^{o}$ 6.096, de 24 de abril de 2007. Institui o Programa de Apoio a Planos de Reestruturação e Expansão das Universidades Federais - REUNI. Brasília: MEC.

Brasil. (2009a). Decreto $n .^{\circ}$ 6.949, de 25 de agosto de 2009. Promulga a Convenção Internacional sobre os Direitos das Pessoas com Deficiência e seu Protocolo 
Facultativo, assinados em Nova York, em 30 de março d 2007. Brasília: Presidência da República.

Brasil (2009b). Decreto $n .^{\circ}$ 6949/2009. Define o acesso a um sistema educacional inclusivo em todos os níveis de ensino. Brasília: MEC

Brasil. (2011). Lei n. ${ }^{o}$ 12.470, de 31 de agosto de 2011. Altera os arts. 21 e 24 da Lei n⿳0 8.212, de 24 de julho de 1991, que dispõe sobre o Plano de Custeio da Previdência Social. Brasília: Presidência da República.

Brasil (2012). Lei $n^{o}$ 12.711, de 29 de agosto de 2012. Dispõe sobre o ingresso nas universidades federais de ensino técnico de nível médio e dá outras providências. Brasília: Presidência da República.

Brasil (2014). Lei n. ${ }^{\circ}$ 13.005, de 25 de junho de 2014. Aprova o Plano Nacional de Educação com vigência por dez anos.

Bucuto, M. C., Almeida, L. S., \& Araújo, A. M. (2014). Expetativas acadêmicas de estudantes universitários em Moçambique: validação de uma versão do questionário de perceções acadêmicas (QPA - Expetativas). In: L. S. Almeida, A. M. Araújo, A. R. Franco \& D. L. Soares (Eds). Cognição, Aprendizagem e Rendimento: I Seminário Internacional. Universidade do Minho.

Bruner, J. (1990). Actos de significado: más allá de la revolución cognitiva. Madrid: Alianza Editorial.

Caiado, K. R. M. (2010). Trajetórias escolares de alunos com deficiência (Ed). São Paulo: EDUFSCAR.

Carvalho, R. E. (1996). Escola Inclusiva: a reorganização do trabalho pedagógico. Porto Alegre: Mediação. 
Carvalho, M. B. W. B. (2006). Política de Educação Especial: o acesso à escola e a responsabilidade do poder público. In A. C. Castro, I. V. Nascimento, R. N. Lima (Eds.). Política Pública de Educação no Brasil: compartilhando saberes e reflexões (pp. 145-168). Porto Alegre: Sulina.

Coulon, A. (2008). A condição de estudante: A entrada na vida universitária. Salvador, BA: UDUFBA.

Creswell. J. W. (2014). Investigação Qualitativa e Projeto de Pesquisa: Escolhendo entre cinco abordagens. Porto Alegre: Penso.

Cunha, C. (2007). Constructing organization through multiplicity: a microgenetic analysis of self-organization in the dialogical self. Internacional Journal for Dialogical Science, 2 (1), 287-316.

Declaração de Salamanca e Linha de Ações sobre necessidades Educativas Especiais. Brasília: CORDE, 1994.

Del Prette, Z. A. P., e Del Prette, A. (1998). Desenvolvimento interpessoal e educação escolar: O enfoque das habilidades sociais. Temas em Psicologia, 6, (3), 205-215.

Denzin, N. K, Lincoln, Y. S. (2006). O planejamento da pesquisa qualitativa: teorias $e$ abordagens. Porto Alegre: Artmed.

Dias, S. (2004). O sujeito por trás do rótulo: significações de si em narrativas de estudantes de ensino médio com indicação de deficiência mental. Dissertação de mestrado, Universidade de Brasília, Brasília.

Dias, S. (2014). A quem serve o diagnóstico de deficiência intelectual? Um estudo do desenvolvimento adulto na perspectiva da Psicologia Dialógica. Tese de doutorado, Universidade de Brasília, Brasília. 
Dias, S., \& Lopes de Oliveira, M. C. S. (2013). Deficiência Intelectual na perspectiva histórico-cultural: Contribuições ao estudo do desenvolvimento adulto. Revista Brasileira de Educação Especial, 19 (2), 169-182.

Duarte, E. R., Rafael, C. B. S., Filgueiras, J. F., Neves, C. M., \& Ferreira, M. E. C. (2013). Estudo de Caso sobre a Inclusão de Alunos com Deficiência no Ensino Superior. Revista Brasileira de Educação Especial, 19, (2), 289-300.

Falsarella, A. M. \& Silva, L. M. (2002). Preconceito na Escola Inclusiva. Revista Presença Pedagógica, 8 (46), 96-106.

Faria, C. P. (2012). Inclusão de alunos com necessidades educativas especiais no ensino superior: Estudo exploratório sobre as perceções dos docentes. Dissertação de Mestrado, Universidade da Madeira, Funchal.

Fávero, M. H. (2005). Desenvolvimento psicológico, mediação semiótica e representações sociais. Psicologia: Teoria e Pesquisa, 21, Jan-Abr.

Fernandes, E., \& Almeida, L. (2007). Estudantes com deficiência na universidade: Questões em torno da sua adaptação e sucesso acadêmico. Revista da Educação Especial e Reabilitação, 14, 7-14.

Fernandes, E. A., Almeida, L., \& Mourão, J. (2007). Inclusive university education viewed by the non disabled students. The Internacional Journal of Diversity in Organizations, Communities and Nations, 7 (1), 169-178.

Fleith, D. S. (2011). A Política Nacional de Educação Especial na Perspectiva da Educação Inclusiva: desafios para o Psicólogo Escolar. In R. S. L. Guzzo \& C.M. MarinhoAraújo. Psicologia Escolar: identificando e superando barreiras. Campinas-SP: Alínea. 
Figueiredo, A. C., Lisboa, C. P., Frederico, C., Cotrim, G., Perez, J., Alves, J. V., Vasconcelos, L. S. \& Almeida, L. M. (2011). Acessibilidade e vida universitária: Pontuações sobre a educação inclusiva. In: S. M. R. Sampaio (Ed.). Observatório da vida estudantil: primeiros estudos. Salvador-BA: EDUFBA.

Flick, U. (2009). Introdução à Pesquisa Qualitativa. Porto Alegre: Artmed.

Fischer, J. (2014). Inclusão de acadêmicos com deficiência na universidade: Possibilidades e desafios. In: S. E. Orrú (Ed.). Para além da educação especial: Avanços e desafios de uma educação inclusiva. Rio de Janeiro: Wak editora.

Freitas, L. C. (2011). Os reformadores empresariais da educação: a consolidação do neotecnicismo no Brasil. Texto apresentado ao $10^{\circ}$ Encontro de Pesquisa em Educação da Região Sudeste. Rio de Janeiro.

Goffman, E. (1988). Estigma: notas sobre a manipulação da identidade deteriorada. Rio de Janeiro: Zahar. (Original publicado em 1963).

Gonçalves, A. F. S. (2010). Políticas públicas e inclusão escolar. In: S. L. Victor, R. Drago e Chicon, J. F. (Eds.). A educação inclusiva de crianças, adolescentes, jovens e adultos: avanços e desafios. Vitória: Edufes.

Gugel, M. A. (2007). Pessoas com Deficiência e o Direito ao Trabalho. Florianópolis: Obra Jurídica.

Jannuzzi, G. M. A. (1992). A luta pela educação do deficiente mental no Brasil. $2^{\mathrm{a}}$ ed. Campinas: Autores Associados.

Kelman, C. A. (2010). Sociedade, educação e cultura. In: D. A. Maciel \&Barbato, S. Desenvolvimento humano, educação e inclusão escolar. Brasília: Editora UnB.

Labov, W. (1996). Principios del cambio lingüístico. Editorial Gredos. 
Leme, M. E. S. (2015). Deficiência e o mundo do trabalho: Discursos e contradições. Campinas: Autores Associados.

Lima, P. A. (2006). Educação Inclusiva e Igualdade Social. São Paulo: Avercamp.

Linell, P. (2009). Rethinking Language, Mind and world dialogically: interactional and contextual theories of human sense-making. Charlotte, NC: Information Age Publishing.

Lopes de Oliveira, M. C. S.(2003). Do sujeito das representações ao sujeito dialógico. Revista de Psicologia da UFF.

Lopes de Oliveira, M. C. S. (2014). Microanálise de narrativas: contribuições ao debate. In: M. C. D. P. Lyra, A. P. Garvey, M. Silva, E. C. Chaves. Microgênese: Estudo do processo de mudança (pp. 329-354). Recife: Editora UFPE.

Lotman, I. (1996). La semioesfera I. Semiótica de la cultura y del texto.Madrid: Cátedra.

Macedo, R. S. (2006). Etnopesquisa crítica, etnopesquisa-formação. Brasília: Liber Livro.

Machado, F. S. \& Nazari, J. (2012). Aspectos históricos das pessoas com deficiência no contexto educacional: Rumo a uma perspectiva inclusiva. Lentes Pedagógicas. 2,(1), 21-36.

Mantoan, M. T. E. (Ed.). (2008). O desafio das diferenças nas escolas. Petrópolis: Vozes.

Mantoan, M. T. E. (2013). Diferenciar para incluir ou para excluir? Por uma pedagogia da $\begin{array}{llll}\text { diferença. } & \text { Disponível http:// }\end{array}$ www.diversa.org.br/artigos/artigos.php?id=2879\&/diferenciar_para_incluir_ou_para_e xcluir_por_uma_pedagogia_da_diferença. Acesso em 22.mar.2014.

Marcondes, M. E. R. S, \& Caiado, K. R. M. (2013). Educação especial: da filantropia ao direito à escola. In K. R. M. Caiado (Ed.). Trajetórias escolares de alunos com deficiência (pp. 35-64). São Carlos, SP: EdUFSCar. 
Marinho-Araújo, C.M. (2009). Psicologia Escolar na educação superior: novos cenários de intervenção e pesquisa. In C.M. Marinho-Araújo (Ed.). Psicologia Escolar: novos cenários e contextos de pesquisa, formação e prática (pp. 155-202). Campinas-SP: Alínea.

Marinho-Araújo, C.M. (2011). Psicologia Escolar e educação superior: construindo possibilidades diferenciadas de atuação. In R. S. L. Guzzo \& C.M. Marinho-Araújo (Eds.). Psicologia Escolar: identificando e superando barreiras. Campinas-SP: Alínea.

Marinho-Araújo, C.M., \& Polidori, M.M. (2012). Análise dos Sistemas de Educação Superior no Brasil e em Portugal: o que apontam as políticas educacionais. Porto Alegre: EDIPUCRS.

Martínez, A. M. (2007). Inclusão Escolar: desafios para o psicólogo. In A. M. Martínez (Ed.). Psicologia Escolar e Compromisso Social (pp. 115-134). Campinas - SP: Alínea.

Martins, J. S. A. (2002). A sociedade vista do abismo: novos estudos sobre exclusão, pobreza e classes sociais. Petrópolis, Vozes.

Maturana, H. (1993). Uma nova concepção de aprendizagem. Aletheia, 26, 146-167.

Mattos, E. de. (2013). Desenvolvimento do self na transição para a vida adulta: um estudo longitudinal com jovens baianos. Tese de doutorado, Universidade Federal da Bahia, Bahia.

Mazzota, M. J. S. (1996) Educação Especial no Brasil: história e políticas públicas. São Paulo: Cortez.

Meletti, S. M.F., \& Bueno, J. G. S. (2011). O impacto das políticas públicas de escolarização de alunos com deficiência: uma análise dos indicadores sociais no Brasil. Linhas Críticas, Ago 2011, 17, (33), 367-383. 
Mendonça, F. L. R. (2013). Entre concepções docentes e práticas pedagógicas: o processo de inclusão de alunos com deficiência intelectual na rede pública de ensino do Distrito Federal. Dissertação de Mestrado, Universidade de Brasília, Brasília.

Michels, L. R. F., Dellecave, M. R. (2005). O que os professores têm dizer sobre a educação inclusiva na universidade. Contrapontos, 5, (2), 469-481.

Ministério da Educação - MEC (2005). Saberes e práticas da inclusão: Recomendações para a construção de escolas inclusivas. Brasília: MEC.

Ministério da Educação - MEC. (2011). Marcos Político-Legais da Educação Especial na Perspectiva da Educação Inclusiva. Brasília: MEC.

Mittler, P. (2003). Educação inclusiva: contextos sociais. Porto Alegre: Artmed.

Miranda, A. A. B.(2003) História, Deficiência e Educação Especial: A prática pedagógica do professor de alunos com deficiência mental. São Paulo: Unimep.

Moreira, L. C. (2010). Práticas Pedagógicas na Universidade e Alunos com Necessidades Educacionais Especiais: entre desafios e buscas. In: S. L. Victor, R. Drago \& J. F. Chicon (Eds). A Educação Inclusiva de Crianças, Adolescentes, Jovens $e$ Adultos. Vitória: Edufes.

Morosini, M. (2005). A Universidade no Brasil: concepções e modelos. 2ªed. Brasília: INEP.

Moroz, M. \& Gianfaldoni, M. H. T. A. (2006). O Processo de Pesquisa Iniciação. Brasília: Líber Livro.

Olive, A. C. (2002). Histórico da educação Superior no Brasil. In: M. S. A. Soares (Ed.). A educação superior no Brasil. Brasília: CAPES.

Oliveira, C. B. E. (2011). A atuação da Psicologia Escolar na Educação Superior: Proposta para os serviços de Psicologia. Tese de doutorado, Universidade de Brasília, Brasília. 
Oliveira, M. A. M., Paschoalino, J. B. Q., \& Rocha, T. C. (2011). Políticas para o ensino superior: profissionalização ou proletarização do trabalho docente? Trabalho \& Educação, Belo Horizonte, 20, (2), 77-89.

Pallú, N. M. (2013). A produção social da identidade e a pedagogia da diferença. Revista Educere et Educare, Cascavel, 8, (16), 505-510.

Paula, L., \& Stafuzza, G. (2008). Círculo de Bakhtin: Teoria inclassificável. São Paulo: Mercado das Letras.

Pires, L. M. F.S. A.(2007). A caminho de um ensino superior inclusivo? A experiência e percepção dos estudantes com deficiência - estudo de caso. Dissertação de Mestrado. Faculdade de Motricidade Humana, Universidade Técnica de Lisboa, Lisboa.

Pieczkowski, T. M. Z., Naujorks, M. I. (2012). Inclusão de Estudantes com Deficiência no Ensino Superior: Diferentes discursos, diferentes expectativas. Atos de Pesqusia em Educação, 7, (3), 938-962.

Pletsch, M. D.(2010). Repensando a inclusão escolar: diretrizes políticas, práticas curriculares e deficiência intelectual. Rio de Janeiro: NAU \& EDUR.

Ponzio, A (2012). A revolução bakhtiniana. São Paulo: Contexto.

Ressurreição, S. B. (2013). Estudantes universitários indígenas: histórias de rupturas e transições. Exame de qualificação de Doutorado. Universidade Federal da Bahia. Salvador, BA.

Ressurreição, S. B.(2015). Jovens indígenas universitários: Experiências de Transições e etnogênese acadêmica. Tese de Doutorado. Universidade Federal da Bahia, Slavador, BA.

Rey, F. G. (2005). Pesquisa Qualitativa e Subjetividade. São Paulo: Pioneira Thomson Learning. 
Riessman, C. K. (2010). Analysis of a Personal Narratives. In: J. F. Gubrium \& J. A. Holstein (Eds.). Handbook of Interviewing. Boston: Sage Publications.

Rosa, A. e Valsiner, J. (2007). General conclusions: socio-cultural psychology on the move: semiotic methodology in the making. In: J. Valsiner \& Rosa, A. (Eds.). The Cambridge Handbook a Sociocultural Psychology. Cambridge: University Press.

Salgado, J. \& Gonçalves, M. (2007). The dialogical self: social, personal, and (un)conscious. In: Valsiner, J \& Rosa, A. (Eds.). The Cambridge handbook of sociocultural psychology.New York: Cambridge University Press.

Sampaio, H. (1991). Evolução do ensino superior brasileiro, 1808-1990. São Paulo: Núcleo de Pesquisas sobre Ensino Superior da Universidade de São Paulo.

Sampaio, S. M. R. (2010). A Psicologia na educação superior: ausências e percalços. In: Marinho-Araújo, C. M. (Ed.). Psicologia Escolar: pesquisa e intervenção. Em Aberto, Brasília: INEP/MEC.

Santos, C. S. (2013). Políticas de acesso e permanência de alunos com deficiência em Universidades Brasileiras e Portuguesas. Tese de Doutorado não publicada - Faculdade de Educação, Universidade Federal de Uberlândia, Uberlândia.

Santos, O. P. (2013). Pedagogia da diferença: Um debate multicultural na educação de surdos. Revista do Difere - Artifícios, 2 ,(3), 1-16.

Sassaki, R. K. (2004). Inclusão - construindo uma sociedade para todos. Rio de Jeneiro: WVA.

Sato, T. \& Valsiner, J. (2010). Time in life and life in time: between experiencing and accounting. Ritsumeikan Journal of Human Sciences, 20, 79-92.

Saviani, D. (2005). História da formação docente no Brasil: três momentos decisivos. Revista Educação Santa Maria, 30, (2), 11-26. 
SECADI/Sesu. (2013). Documento Orientador. Programa Incluir - Acessibilidade na Educação Superior. Brasília.

Severino, A. J. (2008). O ensino superior brasileiro: novas configurações e velhos desafios. Educar, 31, 73-89.

Sguissardi, V.(2011). Universidade no Brasil: dos modelos clássicos aos modelos de ocasião? In: M. Morosini (Ed.). A Universidade no Brasil: concepções e modelos. $2^{\mathrm{a}} \mathrm{ed}$. Brasília: INEP.

Silva, T. T. (2006). Documentos de identidade: uma introdução às teorias do currículo. $2^{\mathrm{a}}$ ed. Belo Horizonte: Autêntica.

Silva, R. H. R. (2014). A pesquisa em educação especial e inclusiva no contexto da pósgraduação em educação no Brasil: Constituição, desafios e perspectivas. In: S. E. Orrú (Ed.). Para além da educação especial: Avanços e desafios de uma educação inclusiva. Rio de Janeiro: Wak editora.

Silva, S. L. R., Ferreira, J. A. G., \& Ferreira, A. G. (2014). Vivências no ensino superior e perceções de desenvolvimento: Dados de um estudo com estudantes do ensino superior politécnico. Revista E-Psi, 4(1), 28-46.

Silverman, D. (2009). Interpretação de dados qualitativos: métodos para análise de entrevistas, textos e interações. Porto Alegre: Artmed.

Simão, L. M. (2001). Alteridade no diálogo e construção de conhecimento. In: A. M. Martinez \& L. M. Simão (Eds.). O outro no desenvolvimento humano: diálogos para a pesquisa e a prática profissional em Psicologia. São Paulo: Pioneira Thomson Learning. 
Skliar, C. (1999). A invenção e a exclusão da alteridade "deficiente" a partir dos significados da normalidade. Educação e Realidade, 24, (1), 15-32.

Smolka, A. L. B. (2004). Sentido e significação: Parte A - sobre significação e sentido: uma contribuição à proposta de rede de significações. In: M. C. Rossetti-Ferreira; K. S. Amorim; A. P. S. Silva e A. M. A. Carvalho (Eds). Rede de significações e o estudo do desenvolvimento humano. Porto Alegre: Artmed.

Sobral, A. (2008). O ato "responsível", ou ato ético, em Bakhtin, e a Centralidade do agente. Signum: Estud. Ling., Londrina, 11, (1), 219-235.

Sousa, A. M., Soares, D. L. e Evangelista, G. B. M. G. (2003). A Universidade de Brasília e a inclusão do aluno com necessidades educativas especiais. Linhas Críticas, 9, (16), 105126.

Sousa Santos, B. (2005). A Universidade no século XXI: Para uma reforma democrática e emancipatória da Universidade. São Paulo: Cortez

Souza, M. L.; \& Gomes, W. (2009). Temporalidade e espacialidade na estrutura do self nas abordagens semiótica e dialógica. Psicologia em Estudo, Maringá, 14, (2), 365-373.

Spink. M. J. P. \& Menegon, V. M. (1999). A pesquisa como prática discursiva: superando os horrores metodológicos. In: M. J. Spink. Práticas Discursivas e Produção de Sentidos no Cotidiano: Aproximações teóricas e metodológicas. São Paulo: Cortez.

Szymanski, H., Alemida, L. R., Prandini, R. C. A. R., (2010). A Entrevista na Pesquisa em Educação: A prática reflexiva. Brasília: Liber Livros.

Trindade, H. (2001). Universidade, ciência e Estado. In: H. Trindade (Ed.). Psicologia Social Contemporânea. Petrópolis: Vozes. 
UNESCO (2001). Educação um tesouro a descobrir: Relatório para a UNESCO da Comissão Internacional sobre Educação para o Século XXI. Brasília: UNESCO e São Paulo: Cortez Editora.

UNESCO (2009).World Conference on Higher Education: The new dinamics of higher education and research for societal change and development. Comunique. Paris: UNESCO.

Valle, J. W., \& Connor, D. J. (2014). Ressignificando a deficiência: Da abordagem social às práticas inclusivas na escola. Porto Alegre: Penso.

Valsiner, J. (2002). Forms of dialogical relations and semiotic autoregulation within the self. Theory \& Psychology, 12, 251-265.

Valsiner, J. (2007). Culture in minds and societies: foundations of cultural psychology. New Delhi: Sage.

Valsiner, J. (2012). Fundamentos da Psicologia Cultural: mundos da mente, mundos da vida. Porto Alegre: Artmed.

Vasconcellos, T. B. de. (2012). Um diálogo sobre a noção de autenticidade. Tese de Doutorado. Universidade de São Paulo, São Paulo.

Ventura, M. M. (2007). O estudo de caso como modalidade de pesquisa. Revista SOCERJ, 20: (5), 383-386.

Villatore, M. A. C. \& Silva, J. L. (2009). Os 60 anos da declaração Universal dos Direitos Humanos e seus reflexos sociais e econômicos nos direitos das pessoas com deficiência. In: Folmann, M. (Ed.). Direitos Humanos: os 60 anos da Declaração Universal da ONU. Curitiba: Juruá. 
Vygotsky, L. S. (1995). Fundamentos de Defectologia. (Obras Completaas - Tomo 5). Havana: Pueblo y Educación.(Obra orinalmente publicda em 1983).

Vygotsky, L. S. (1989). A Formação Social da Mente. São Paulo: Martins Fontes.

Xavier, C. R. (2012). Modelo para mudança de atitudes sociais em relação à inclusão. Revista Galego-Portuguessa de Psicoloxía e Educación, 20 (1), 83-98.

Zago, N. (2011). Egressos do ensino médio da rede pública e o acesso ao ensino superior: Entre oportunidades e limitações. In: M. de C. M. Kassar. (Ed.). Diálogos com a Diversidade: Sentidos da inclusão. São Paulo: Mercado das Letras.

Zanella, A. V. (1998). Sujeito e Alteridade: Reflexões a partir da Psicologia histórico-cultural. Psicologia e Sociedade, .17, (2), 99-104.

Zanella, A. V. (2013). Perguntar, registrar, escrever: inquietações metodológicas. Porto Alegre: Sulina.

Zanella, A. V., Lessa, C. T., Da Ros, S. Z. (2002). Contextos Grupais e Sujeitos em Relação: Contribuições às Reflexões sobre Grupos Sociais. Psicologia: Reflexão e Crítica, 15, (1), 211-218.

Zeppone, R. M., \&, O. Brito. (2013). Ensino superior e pessoas com deficiência: mapeamento de teses e dissertações. In: K. R. M. Caiado (Ed.). Trajetórias escolares de alunos com deficiência. São Paulo: EDUFSCAR.

Zittoun, T. (2007). Symbolic resources and responsability in transitions. Young, 15, (2), 193211.

Zittoun, T. (2009). Dynamics of Life-Course Transitions: A Methodological Reflection.Dynamic Process Methodology in the Social and Developmental Sciences. Switzerland. 


\section{APÊNDICES}

Apêndice 1- Guia geral de entrevista - estudante.

Apêndice 2- Roteiro com questões para entrevista semiestruturada individual aos estudantes.

Apêndice 3 -Guia geral de entrevista - sistema de apoio.

Apêndice 4- Roteiro com questões para entrevista semiestruturada individual aos responsáveis pelos serviços institucionais de apoio. 
Apêndice 1: Guia geral de entrevista - estudante

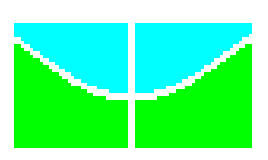

Universidade de Brasília - UnB

Departamento de Psicologia Escolar e do Desenvolvimento - PED/IP

Programa de Pós-Graduação em Processos de Desenvolvimento Humano e Saúde PG-PDS

GUIA GERAL DE ENTREVISTA - ESTUDANTE

IDENTIFICAÇÃO:

IDADE: SEXO:

CURSO:

ENSINO MÉDIO: ESCOLA PÚBLICA $\bigcirc$ ESCOLA PARTICULAR

PERÍODO LETIVO: PERÍODO DE INGRESSO:

EIXOS NORTEADOARES:

1. PERCEPÇÕES SOBRE A INCLUSÃO:

- SUA PERCEPÇÃO

- A PERCEPÇÃO DA SOCIEDADE

- A PERCEPÇÃO DA UNIVERSIDADE

2. TRAJETÓRIA DE ESTUDOS (AO LONGO DA VIDA):

- ELEMENTOS FACILITADORES

- ELEMENTOS DIFICULTADORES

3. EXPERIÊNCIAS INDIVIDUAIS

- MOMENTO/EVENTO MARCANTE

- SIGNIFICADOS

4. OUTROS 


\title{
Apêndice 2: Roteiro com questões para entrevista semi-estruturada individual aos
}

\author{
estudantes

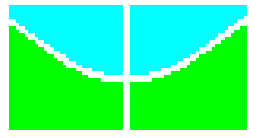 \\ Universidade de Brasília - UnB \\ Departamento de Psicologia Escolar e do Desenvolvimento - PED/IP \\ Programa de Pós-Graduação em Processos de Desenvolvimento Humano e Saúde PG-PDS
}

Questões para entrevista semi-estruturada individual aos estudantes

1. Como você me contaria sua vida?

2. E sua trajetória escolar? Que momentos você destaca como importantes, marcantes na história escolar?

3. Você lembra de alguma dificuldade no desempenho escolar? Você saberia identificar as causas desta(s) dificuldade(s)?

4. Como você lida com a deficiência em sua vida? Como você a percebe?

5. Você considera que a deficiência já comprometeu de alguma forma o desenvolvimento de seus estudos? Como?

6. Como se deu o seu acesso ao ensino superior?

7. Você se considera satisfeito com a Universidade? Como está o seu aproveitamento dos estudos?

8. Há dificuldades para exercer suas atividades estudantis? Quais?

9. Nas situações de dificuldades, você busca apoio? De quem? Encontra ajuda?

10. O que você destacaria como ponto positivo na Universidade para lhe oportunizar aproveitamento escolar e permanência? Há pontos negativos? Quais? 
11. Você teria alguma sugestão que pudesse qualificar o atendimento às demandas dos alunos em relação à Universidade?

12. Ao fim de seu curso, quais são suas expectativas para o futuro? 
Apêndice 3: Guia Geral de entrevista - Sistema de Apoio

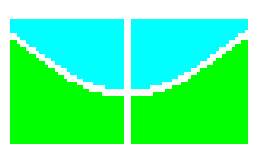

Universidade de Brasília - UnB

Departamento de Psicologia Escolar e do Desenvolvimento - PED/IP

Programa de Pós-Graduação em Processos de Desenvolvimento Humano e Saúde PG-PDS

\section{Guia geral de entrevista - sistema de apoio}

IDENTIFICAÇÃO:

IDADE: SEXO: ÁREA:

FUNÇÃO:

EIXOS NORTEADOARES:

1. PERCEPÇÕES SOBRE A INCLUSÃO:

- SUA PERCEPÇÃO

- A PERCEPÇÃO DA SOCIEDADE

- A PERCEPÇÃO DA UNIVERSIDADE

2. EM RELAÇÃO AO TRABALHO/FUNÇÃO DESEMPENHADA:

- ELEMENTOS FACILITADORES

- ELEMENTOS DIFICULTADORES

3. OUTROS 


\section{Apêndice 4: Roteiro com questões para entrevista semi-estruturada individual aos serviços de apoio}

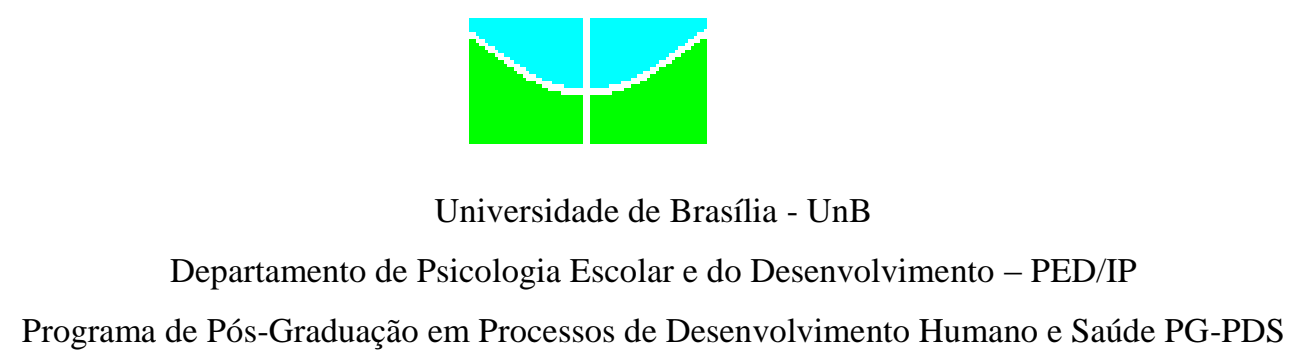

1. Na sua opinião, como a universidade tem percebido a inclusão?

2. Como estão organizados os serviços?

3. A equipe é composta por quem?

4. E como os estudantes acessam os serviços?

5. Quais têm sido as principais demandas apresentadas pelos estudantes?

6. Como os alunos reagem à organização dos serviços?

7. Há ações institucionais de sensibilização para a universidade? Como são organizadas?

8. O que fazem os técnicos e/ou voluntários? Como atuam?

9. O que tem sido facilitador ou dificultador aqui no trabalho?

10. E quem é o público? Como lidar com a questão das deficiências?

11. O que os alunos trazem como maiores dificuldades?

12. E pensando nas barreiras, quais são as dificuldades mais significativas relatadas?

13. Quais são os desafios para o serviço de apoio? 


\begin{abstract}
ANEXOS
Anexo 1: Termo de consentimento livre e esclarecido

Anexo 2: Parecer do Comitê de Ética em Pesquisa
\end{abstract}




\title{
Anexo 1: Termo de Consentimento Livre e Esclarecido
}

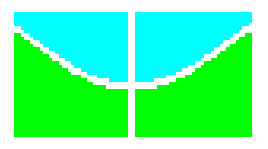 \\ Universidade de Brasília - UnB \\ Departamento de Psicologia Escolar e do Desenvolvimento - PED/IP \\ Programa de Pós-Graduação em Processos de Desenvolvimento Humano e Saúde PG-PDS \\ Título (provisório) da pesquisa: Trajetórias de desenvolvimento de jovens com \\ necessidades educacionais especiais no ensino superior \\ Responsável: Ana Claudia Rodrigues Fernandes \\ Supervisão: Prof. Dra ${ }^{\mathrm{a}}$. Maria Claudia Santos Lopes de Oliveira
}

\section{TERMO DE CONSENTIMENTO LIVRE E ESCLARECIDO}

Você está sendo convidado a participar de uma investigação sobre trajetórias de desenvolvimento de jovens com necessidades educacionais especiais no ensino superior, realizada pela Universidade de Brasília, sob minha responsabilidade. O objetivo do trabalho é discutir os processos de desenvolvimento de indivíduos com necessidades educacionais especiais no ensino superior, conhecendo as trajetórias percorridas pelos estudantes ao longo de seus cursos de graduação. Assim, gostaria de consultá-lo sobre seu interesse e disponibilidade em cooperar com a pesquisa.

Você receberá todos os esclarecimentos necessários antes, durante e após a finalização da pesquisa e lhe asseguro que seu nome não será divulgado em nenhuma hipótese, sendo mantido o mais rigoroso sigilo mediante a omissão total de informações que possam identificá-lo. Os dados resultantes da pesquisa, tais como entrevistas ou relatos de observação ficarão sob minha responsabilidade e guarda.

A presente investigação se dará por meio de entrevistas individuais (a serem gravadas em áudio) e observações das situações cotidianas escolares (sala de aula, biblioteca, etc...). É para estes procedimentos que você está sendo convidado a participar. Sua participação não 
implica em nenhum risco e você poderá ter acesso a todos os resultados e conclusões dela derivados.

Sua participação é voluntária, livre de qualquer remuneração ou benefício direto ao participante. Você é livre para recusar-se a participar, retirar seu consentimento ou interromper sua participação a qualquer momento. A recusa em participar não irá acarretar qualquer penalidade.

Sua assinatura significa que você leu este consentimento, esclareceu suas dúvidas e concordou em participar nos termos indicados. O telefone de contato da pesquisadora encontra-se ao final do presente termo, para qualquer dúvida posterior.

Este projeto foi revisado pelo Comitê de Ética em Pesquisa do Instituto de Ciências Humanas da Universidade de Brasília - CEP /IH. Mias informações a respeito da assinatura do presente termo ou dos direitos do sujeito de pesquisa podem ser obtidos através do email do CEP/IH: CEP_ih@unb.br.

O presente termo foi elaborado em duas vias, uma ficará com a pesquisadora e a outra com o participante.

Desde já, obrigada por sua participação!

Ass. Participante

Ass. Pesquisadora

Contato:

Ana Claudia R. Fernandes

Fone: (61) 8410-6966 
Anexo 2: Parecer do Comitê de Ética em Pesquisa 


\section{INSTITUTO DE CIENCIAS \\ HUMANAS / UNIVERSIDADE DE BRASÍLIA / CAMPUS}

\section{PARECER CONSUBSTANCIADO DO CEP \\ DADOS DO PROJETO DE PESQUISA}

\section{Título da Pesquisa:}

Trajetórias de desenvolvimento de jovens com necessidades educacionais especiais no ensino superior

Pesquisador: Ana Claudia Rodrigues Fernandes

Área Temática:

Versão: 2

CAAE: 19021113.3 .0000 .5540

Instituição Proponente: Instituto de Ciências Humanas/UNB

Patrocinador Principal: $\quad$ Financiamento Próprio

\section{DADOS DO PARECER}

Número do Parecer: 433.354

Data da Relatoria: 27/09/2013

\section{Apresentação do Projeto:}

O presente projeto tem como tema a inclusão escolar dos indivíduos com necessidades educacionais na esfera do ensino superior, a partir de um paradigma sócio-cultural em que a história das relações significativas constroem os processos de significação do indivíduo, marcando sua trajetória, seu desenvolvimento. Com a presente abordagem pretende-se 
interligar a trajetória subjetiva e a vidaacadêmica do indivíduo com necessidades educacionais especiais, considerando, para isso, os sistemas de significados individuais e sociais dos estudantes, suas relações com os demais sujeitos sociais, e o modo como se organiza frente o ofício de estudante do ensino superior, tendo em conta as relações acadêmicas, políticas e institucionais ali estabelecidas. A etapa empírica da pesquisa consistirá em observação etnográfica do cotidiano de 12 estudantes com deficiência da UnB e entrevistas individuais com os mesmos estudantes.

\section{Objetivo da Pesquisa:}

Objetivo Primário:

Discutir os processos de desenvolvimento de indivíduos com necessidades educacionais especiais no ensino superior, conhecendo as trajetórias percorridas e os sistemas de significados individuais.

Objetivo Secundário:

1. Mapear o cenário da educação superior inclusiva, em particular, dados que se referem a ingresso, evasão,

permanência e conclusão do curso de graduação, por estudantes que se auto-identificam com necessidades educacionais especiais nas Instituições de Ensino Superior, no contexto nacional. 2. Identificar as IES, no DF, que dispõem de algum sistema de apoio didático ao aluno com necessidades educacionais especiais.

3. Analisar os processos de desenvolvimento dos estudantes, egressos e/ou desistentes do ensino superior na Universidade de Brasília - UnB, com necessidades educacionais especiais, em termos de análises de significados e trajetórias de desenvolvimento.

4. Aprofundar a compreensão sobre dificuldades e potencialidades do cotidiano das práticas inclusivas no ensino superior, a partir de estudo de caso que investigará a proposta de Inclusão da Universidade de Brasília-UnB.

\section{Comentários e Considerações sobre a Pesquisa:}

O projeto de pesquisa é relevante e poderá resultar em resultados que contribuirão para o aperfeiçoamento do atendimento a estudantes com deficiência no ensino superior. Entretanto, 
faltou apresentar: 1. Os instrumentos de coleta de dados; 2. explicar como será obtido o consentimento de estudantes com

deficiência que não possam ler o TCLE no formato em que foi elaborado ou mesmo expressar por escrito a concordância em participar do estudo.

Considerações sobre os Termos de apresentação obrigatória:

Foram apresentados a carta de aceite institucional e o TCLE. Entretanto, faz-se necessário elaborar alternativas o TCLE no formato escrito tendo em vista a diversidade corporal entre estudantes com deficiência e a necessidade de contemplar tal diversidade, tais como estudantes com deficiência visual, auditiva ou mesmo estudantes que utilizam outros meios de comunicação que não seja a escrita.

\title{
Recomendações:
}

\section{Conclusões ou Pendências e Lista de Inadequações:}

Aprovação

\section{Situação do Parecer:}

Aprovado

Necessita Apreciação da CONEP:

Não

\section{Considerações Finais a critério do CEP:}

BRASILIA, 23 de Outubro de 2013

\author{
Assinador por: \\ Soraya Fleischer \\ (Coordenador)
}

